RENATA NEVES PENHA

\title{
Modelagem do processo de revenimento por redes neurais
}

\author{
Tese apresentada à Escola de \\ Engenharia de São Carlos da \\ Universidade de São Carlos como parte \\ dos requisitos para a obtenção do título \\ de Doutora em Engenharia Mecânica. \\ Área de concentração: Materiais
}

Orientadora: Profa Dra Lauralice C. Franceschini Canale

São Carlos

2010 
AUTORIZO A REPRODUÇÃO E DIVULGAÇÃO TOTAL OU PARCIAL DESTE TRABALHO, POR QUALQUER MEIO CONVENCIONAL OU ELETRÔNICO, PARA FINS DE ESTUDO E PESQUISA, DESDE QUE CITADA A FONTE.

Ficha catalográfica preparada pela Seção de Tratamento da Informação do Serviço de Biblioteca - EESC/USP

Penha, Renata Neves
Modelagem do processo de revenimento por redes neurais
/ Renata Neves Penha ; orientadora Lauralice C.
Franceschini Canale. -- São Carlos, 2010.
Tese (Doutorado-Programa de Pós-Graduação em
Engenharia Mecânica e Área de Concentração em Materiais)
-- Escola de Engenharia de São Carlos da Universidade de
São Paulo, 2010.
1. Revenido. 2. Redes neurais. 3.Modelagem. 4.
Propriedades mecânicas. I. Título.


FOLHA DE JULGAMENTO

Candidato(a): Engenheira RENATA NEVES PENHA.

Tese defendida e julgada em 07/06/2010 perante a Comissão Julgadora:

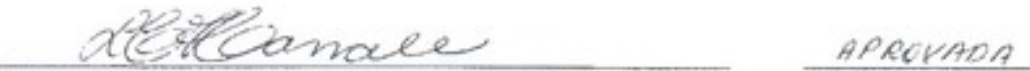

Prof'. Associada LAURALICE DE CAMPOS FRANCESCHINI CANALE - (Orientadora) (Escola de Engenharia de Săo Carlos/USP)

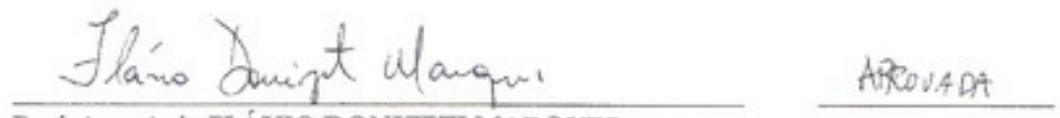

Prof. Associado FLÁVIO DONIZETI MARQUES

(Escola de Engenharia de São Carlos/USP)

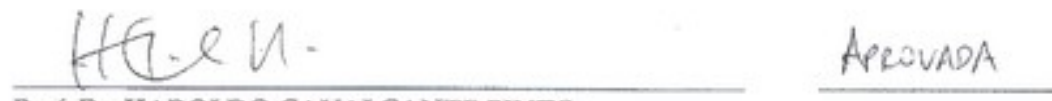

Prof. Dr. HAROLDO CAVALCANTE PINTO

(Escola de Engenharia de São Carlos/USP)
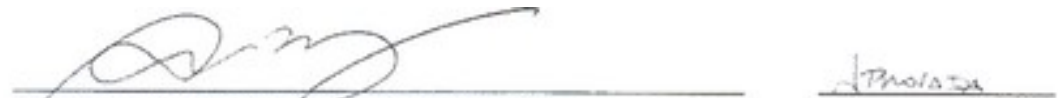

Prof. Dr. ALESSANDRÓ FRAGA FARAH

(Universidade Paulista/UNIP/Campus de Araraquara)

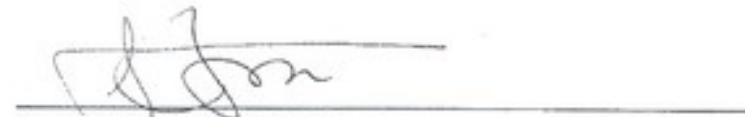

Prof. Dr. JAN VATAVUK

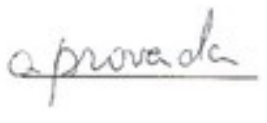

(Universidade Présbiteriana Mackenzie)

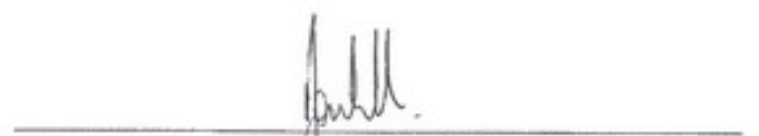

Prof. Associado JONAS DE CARVALHO

Coordenador do Programa de Pós-Graduaçã̃o $\mathrm{em}$ Engenharia Mecânica

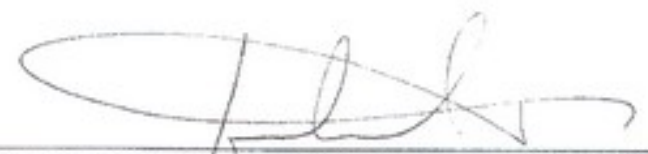

Prof. Titular GERALDO ROBERTO MARTINS DA COSTA

Presidente da Comissão da Pós-Graduação da EESC 


\section{AGRADECI MENTOS}

À professora Lauralice pela orientação e principalmente pela confiança que permitiu a realização deste trabalho. Obrigada pelo conhecimento e pela experiência que me foram transmitidas durante todo este tempo.

À minha família, em especial aos meus pais, pelo incentivo e apoio.

À CAPES pela bolsa de estudos.

Aos professores Cassius e Waldeck que gentilmente cederam o laboratório para a execução dos testes de tração.

Aos amigos e colegas de departamento: Cristina, Henry e Gustavo pelo apoio e amizade.

A todos os funcionários do Departamento de Materiais que ajudaram direta ou indiretamente na elaboração desta tese. 


\section{RESUMO}

PENHA, R. N. (2010). Modelagem do processo de revenimento por redes neurais. 151f. Tese (Doutorado) - Escola de Engenharia de São Carlos, Universidade de São Paulo, São Carlos, 2010.

Os resultados dos processos de alívio de tensões e demais alterações em propriedades mecânicas no revenimento são dependentes do tempo e da temperatura do processo o qual pode ser correlacionado usando algum parâmetro como o de Holloman-Jaffe ou o de Larsen-Miller. Estes parâmetros medem o efeito térmico do processo na transformação metalúrgica do aço durante o revenimento. Processos apresentando o mesmo parâmetro devem apresentar o mesmo efeito nas propriedades mecânicas, como a dureza, por exemplo. No entanto, expressões numéricas mais tradicionais assumem que o processo de revenimento é isotérmico, 0 que raramente acontece nos fornos de produção, devido ao período de aquecimento anterior ao encharcamento na temperatura de revenimento desejada. Embora a equação de Larsen-Miller e o parâmetro de Holloman-Jaffe sejam bem conhecidos, suas origens e limitações, e em alguns casos seus usos, geralmente não são discutidos em detalhes na maioria dos textos de tratamento térmico. Assim o que se deseja é estabelecer uma relação numérica mais precisa, utilizando redes neurais para simular os efeitos do processo de revenimento dos aços para beneficiamento, através da previsão de suas propriedades mecânicas.

Palavras-chave: revenimento, redes neurais, modelagem, propriedades mecânicas. 


\section{ABSTRACT}

PENHA, R. N. (2010). Modeling of tempering process by means of neural networks. 151p. Thesis (Doctoral) - Escola de Engenharia de São Carlos, Universidade de São Paulo, São Carlos, 2010.

The process results of stress relief and other alterations on mechanical properties on tempering are function of time and temperature process, which can be correlated using some parameter as Hollomon-Jaffe or Larsen-Miller. These parameters measure the process thermal effect of metallurgical transformation of steel during tempering. Processes showing the same parameter should have the same effect on mechanical properties, as hardness, for example. However, traditional numerical equations assume that the tempering process is isothermal, what rarely happens in production furnaces, due of the heating time prior to soaking on the desired tempering temperature. Although the equation of Larsen-Miller and the HollomonJaffe parameter are well known, their origins and limitation, and in some case their uses, generally are not discussed in details in the majority of heat treatments texts. So if what it tor establish a more accurate numerical relation, using neural networks for simulating the effects of the tempering process, through its mechanical properties.

Key-words: tempering, neural networks, modeling, mechanical properties. 


\section{LISTA DE FI GURAS}

Figura 1: Relação entre a dureza e o tempo e a temperatura de revenimento (BROOKS, 1996)....

Figura 2: Diagrama ferro-carbono (AMERICAN SOCIETY FOR METALS, 1998)....... 27

Figura 3: Diagrama TTT para o aço SAE 4130 (AMERICAN SOCIETY FOR METALS, 1998).

Figura 4: Estruturas cristalinas: (a) austenita, cfc, (b) ferrita, ccc, e (c) martensita, tcc (AMERICAN SOCIETY FOR METALS, 1998).

Figura 5: Esquema da estrutura ortorrômbica da cementita (AMERICAN SOCIETY FOR METALS, 2003).

Figura 6: Intervalos de formação da martensita tipo ripas e tipo placas (KRAUSS, 1990).

Figura 7: Deslocamentos do átomo de ferro devido aos átomos de carbono na martensita (COHEN, 1962).

Figura 8: Tratamento térmico dos aços (Adaptado de AMERICAN SOCIETY FOR METALS, 1998)....

Figura 9: Efeito do tempo e temperatura de revenimento na dureza (GRANGE e BAUGHMAN, 1956).

Figura 10: Efeito do tempo e da temperatura na dureza do aço W1 (Adaptado de HOLLOMON e JAFFE, 1945)

Figura 11: Dureza como função do tempo para três temperaturas de revenimento de um aço Fe-1,2C (KRAUSS, 1990).

Figura 12: Microdureza em função da temperatura de revenimento para um aço com $0,2 \%$ de carbono (KRAUSS, 1990).

Figura 13: Comparação das curvas de revenimento dos aços SAE 1040 e SAE 2340 (BAIN e PAXTON, 1961).....

Figura 14: Influência quantidade de molibdênio no endurecimento secundário para aços temperados com 0,35\% C (BAIN e PAXTON, 1961).

Figura 15: Energia de impacto e dureza em função da temperatura de revenimento de um aço 0,45\% C (Adaptado de BROOKS, 1996)....

Figura 16: Curvas de revenimento para um aço carbono revenido em diferentes temperaturas (BROOKS, 1996). 
Figura 17: Temperatura de transição em função da temperatura de revenimento, derivado da Figura 16 (BROOKS, 1996). 39

Figura 18: Energia de impacto em função da temperatura de teste para os aços $\mathrm{SAE}$ 1013 e SAE 4315 (BROOKS, 1996). 39

Figura 19: Variações nas propriedades mecânicas em relação à temperatura de revenimento para os aços (a) SAE 1040 e (b) SAE 4340 (Adaptado de BETHLEHEM STEEL CORPORATION, 1972)... 40

Figura 20: Curvas tensão-deformação obtidas para a martensita tipo ripas de um aço carbono Fe-0,2C temperado e temperado e revenido (KRAUSS, 1990).. 41

Figura 21: Quantidade de austenita retida e de cementita em função da temperatura de revenimento para os aços 4130 e 4340 (KRAUSS, 1990). 45

Figura 22: Variações dimensionais em decorrência do revenimento para 0 aço ferramenta 01 (AMERICAN SOCIETY FOR METALS, 1998). 48

Figura 23: Dureza da martensita revenida em ligas de aço Fe-C. Estas curvas mostram a relação da quantidade de carbono e dureza após 0 revenimento em várias temperaturas por uma hora (GRANGE; HIBRAL e PORTER, 1977).

Figura 24: Energia de impacto absorvida em um corpo de prova Charpy não entalhado para aços com diferentes teores de carbono e fósforo (KRAUSS, 1990). 52

Figura 25: Nomograma ilustrando a relação tempo de revenimento, temperatura de revenimento e o parâmetro de Hollomon-J affe (Adaptado de Hollomon e Jaffe, 1945) 54

Figura 26: Curva mestre de revenimento para o aço AISI 4340 temperado em óleo após austenitização a $816^{\circ} \mathrm{C}$ (NEHRENBERG, 1950). 55

Figura 27: Determinação gráfica do parâmetro do material $c$ dos dados de ruptura (HUANG, 2003). 56

Figura 28: Variação da dureza em relação à quantidade de carbono (GRANGE e BAUGHMAN, 1956). 57

Figura 29: Curvas de revenimento para os aços carbono AISI 1030, 1050 e 1080 (GRANGE e BAUGHMAN, 1956) 57

Figura 30: Curva de revenimento para os aços (a) AISI 4340 e (b) AISI 5140 (GRANGE e BAUGHMAN, 1956).. 58

Figura 31: Gráfico da arquitetura de uma rede MLP com duas camadas ocultas (HAYKIN, 1994). 61 
Figura 32: Direção dos dois sinais básicos em uma rede de retropropagação (HAYKIN, 1994). 62

Figura 33: I déia da validação cruzada (HAYKIN, 1994) .................................... 73

Figura 34: Corpo de prova cilíndrico para teste de tração de materiais metálicos... 76

Figura 35: Curvas típicas de tração obtidas para um material (a) dúctil e para um (b) frágil. 77

Figura 36: Diagrama de dispersão indicando o melhor ajuste obtido por regressão linear. 79

Figura 37: LRT obtidos para o aço AISI 4140 revenido em diversas condições........ 84

Figura 38: LRT obtidos para o aço AISI 4340 revenido em diversas condições........ 85

Figura 39: LRT obtidos para o aço AISI 5160 revenido em diversas condições........ 85

Figura 40: LRT obtidos para o aço AISI 6150 revenido em diversas condições........ 86

Figura 41: LRT obtidos para o aço AISI E52100 revenido em diversas condições.... 86

Figura 42: Tensão de ruptura obtida para o aço AISI 4140 ............................... 87

Figura 43: Tensão de ruptura obtida para o aço AISI 4340 .............................. 87

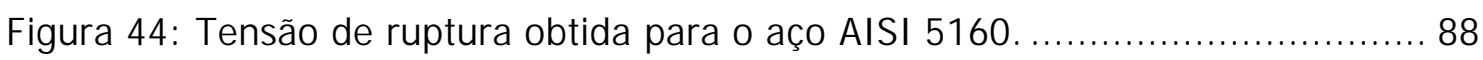

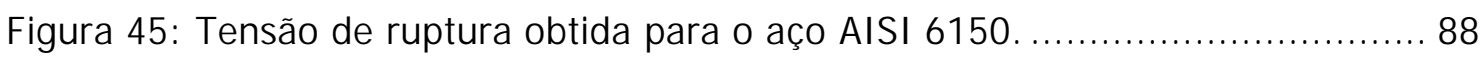

Figura 46: Tensão de ruptura obtida para o aço AISI E52100............................. 89

Figura 47: Limite de escoamento obtido para o aço AISI 4140.......................... 90

Figura 48: Limite de escoamento obtido para o aço AISI 4340........................... 90

Figura 49: Limite de escoamento obtido para o aço AISI 5160.......................... 91

Figura 50: Limite de escoamento obtido para o aço AISI 6150 ........................... 91

Figura 51: Limite de escoamento obtido para o aço AISI E52100 ....................... 92

Figura 52: Módulo de resiliência obtido para o aço AISI 4140............................. 93

Figura 53: Módulo de resiliência obtido para o aço AISI 4340.............................. 93

Figura 54: Módulo de resiliência obtido para o aço AISI 5160.............................. 94

Figura 55: Módulo de resiliência obtido para o aço AISI 6150............................. 94

Figura 56: Módulo de resiliência obtido para o aço AISI E52100.......................... 95 
Figura 57: Módulo de tenacidade obtido para o aço AISI 4140 revenido em diferentes condições. 96

Figura 58: Módulo de tenacidade obtido para o aço AISI 4340 revenido em diferentes condições. 96

Figura 59: Módulo de tenacidade obtido para o aço AISI 5160 revenido em diferentes condições.

Figura 60: Módulo de tenacidade obtido para o aço AISI 6150 revenido em diferentes condições. 97

Figura 61: Módulo de tenacidade obtido para o aço AISI E52100 revenido em diferentes condições.

Figura 62: Rede neural com 10 variáveis de entrada e duas camadas ocultas e uma camada de saída. 99

Figura 63: Decaimento do erro durante o treinamento da RNA construída para calcular a dureza. 100

Figura 64: Soma dos pesos quadráticos durante o treinamento da RNA construída para calcular a dureza. 101

Figura 65: Parâmetros efetivamente utilizados durante o treinamento da RNA construída para calcular a dureza. 101

Figura 66: Correlação entre a dureza medida e a dureza calculada pela RNA para o conjunto de treinamento. 102

Figura 67: Correlação entre a dureza medida e a dureza calculada pela RNA para o conjunto de teste. 103

Figura 68: Comparação dos resultados da dureza medida experimentalmente, calculada pela RNA e pelo parâmetro H-J para o aço AISI 4140 . 104

Figura 69: Comparação dos resultados da dureza medida experimentalmente, calculada pela RNA e pelo parâmetro H-J para o aço AISI 4340. 104

Figura 70: Comparação dos resultados da dureza medida experimentalmente, calculada pela RNA e pelo parâmetro H-J para o aço AISI 5160 . 105

Figura 71: Comparação dos resultados da dureza medida experimentalmente, calculada pela RNA e pelo parâmetro H-J para o aço AISI 6150. 106

Figura 72: Comparação dos resultados da dureza medida experimentalmente, calculada pela RNA e pelo parâmetro H-J para o aço AISI E52100.......106

Figura 73: Rede neural com 10 variáveis de entrada e três camadas ocultas e uma camada de saída. 108 
Figura 74: Decaimento do erro durante o treinamento da RNA construída para calcular o LRT.

Figura 75: Soma dos pesos quadráticos durante o treinamento da RNA construída para calcular o LRT. 109

Figura 76: Parâmetros efetivamente utilizados durante o treinamento da RNA construída para calcular o LRT. 109

Figura 77: Correlação entre o LRT medido e o LRT calculado pela RNA para o conjunto de treinamento.

Figura 78: Correlação entre o LRT medido e o LRT calculado pela RNA para o conjunto de teste.

Figura 79: Comparação dos resultados calculados pela RNA com os valores medidos para o LRT obtido pelo conjunto de teste do aço AISI 4140

Figura 80: Comparação dos resultados calculados pela RNA com os valores medidos para o LRT obtido pelo conjunto de teste do aço AISI 4340.

Figura 81: Comparação dos resultados calculados pela RNA com os valores medidos para o LRT obtido pelo conjunto de teste do aço AISI 5160.

Figura 82: Comparação dos resultados calculados pela RNA com os valores medidos para o LRT obtido pelo conjunto de teste do aço AISI 6150.

Figura 83: Comparação dos resultados calculados pela RNA com os valores medidos para o LRT obtido pelo conjunto de teste do aço AISI E52100. 114

Figura 84: Rede neural com 10 variáveis de entrada e duas camadas ocultas, cada uma com 7 e 14 neurônios e uma camada de saída.

Figura 85: Decaimento do erro durante o treinamento da RNA construída para calcular o limite de escoamento.

Figura 86: Soma dos pesos quadráticos durante o treinamento da RNA construída para calcular o limite de escoamento.

Figura 87: Parâmetros efetivamente utilizados durante o treinamento da RNA construída para calcular o limite de escoamento.

Figura 88: Correlação entre o LE medido e o LE calculado pela RNA para o conjunto de treinamento

Figura 89: Correlação entre o LE medido e o LE calculado pela RNA para o conjunto de teste.

Figura 90: Comparação dos resultados calculados pela RNA com os valores medidos para o LE obtido pelo conjunto de teste do aço AISI 4140 
Figura 91: Comparação dos resultados calculados pela RNA com os valores medidos para o LE obtido pelo conjunto de teste do aço AISI 4340. 119

Figura 92: Comparação dos resultados calculados pela RNA com os valores medidos para o LE obtido pelo conjunto de teste do aço AISI 5160. 120

Figura 93: Comparação dos resultados calculados pela RNA com os valores medidos para o LE obtido pelo conjunto de teste do aço AISI 6150. 120

Figura 94: Comparação dos resultados calculados pela RNA com os valores medidos para o LE obtido pelo conjunto de teste do aço AISI E52100. 121

Figura 95: Arquitetura da rede neural proposta para calcular a tensão de ruptura. 122

Figura 96: Decaimento do erro durante o treinamento da RNA construída para calcular a tensão de ruptura. 122

Figura 97: Soma dos pesos quadráticos durante o treinamento da RNA construída para calcular a tensão de ruptura. 123

Figura 98: Parâmetros efetivamente utilizados durante o treinamento da RNA construída para calcular a tensão de ruptura. 123

Figura 99: Correlação entre a $\sigma_{r}$ medida e a $\sigma_{r}$ calculada pela RNA para o conjunto de treinamento. 124

Figura 100: Correlação entre a $\sigma_{r}$ medida e a $\sigma_{r}$ calculada pela RNA para o conjunto de teste. 124

Figura 101: Comparação dos resultados calculados pela RNA com os valores medidos para a $\sigma_{\mathrm{r}}$ obtido pelo conjunto de teste do aço AISI 4140. 125

Figura 102: Comparação dos resultados calculados pela RNA com os valores medidos para a $\sigma_{r}$ obtido pelo conjunto de teste do aço AISI 4340 . 126

Figura 103: Comparação dos resultados calculados pela RNA com os valores medidos para a $\sigma_{r}$ obtido pelo conjunto de teste do aço AISI 5160. 126

Figura 104: Comparação dos resultados calculados pela RNA com os valores medidos para a $\sigma_{\mathrm{r}}$ obtido pelo conjunto de teste do aço AISI 6150. 127

Figura 105: Comparação dos resultados calculados pela RNA com os valores medidos para a $\sigma_{r}$ obtido pelo conjunto de teste do aço AISI E52100.

Figura 106: RNA com 6 variáveis de entrada e duas camadas ocultas com 4 e 8 neurônios. 128

Figura 107: Decaimento do erro durante o treinamento da RNA construída para calcular o módulo de resiliência. 129 
Figura 108: Soma dos pesos quadráticos durante o treinamento da RNA construída para calcular o módulo de resiliência.

Figura 109: Parâmetros efetivamente utilizados durante o treinamento da RNA construída para calcular o módulo de resiliência..... 130

Figura 110: Correlação entre o $U_{r}$ medido e o $U_{r}$ calculado pela RNA para o conjunto de treinamento

Figura 111: Correlação entre o $U_{r}$ medido e o $U_{r}$ calculado pela RNA para o conjunto de teste.

Figura 112: Comparação dos resultados calculados pela RNA com os valores medidos para o $U_{r}$ obtido pelo conjunto de teste do aço AISI 4140

Figura 113: Comparação dos resultados calculados pela RNA com os valores medidos para o $U_{r}$ obtido pelo conjunto de teste do aço AISI 4340 132

Figura 114: Comparação dos resultados calculados pela RNA com os valores medidos para o $U_{r}$ obtido pelo conjunto de teste do aço AISI 5160 133

Figura 115: Comparação dos resultados calculados pela RNA com os valores medidos para o $\mathrm{U}_{\mathrm{r}}$ obtido pelo conjunto de teste do aço AISI 6150.

Figura 116: Comparação dos resultados calculados pela RNA com os valores medidos para o $U_{r}$ obtido pelo conjunto de teste do aço AISI E52100.... 134

Figura 117: Arquitetura da rede utilizada para calcular o módulo de tenacidade....134

Figura 118: Decaimento do erro durante o treinamento da RNA construída para calcular o módulo de tenacidade. 135

Figura 119: Decaimento do erro durante o treinamento da RNA construída para calcular o módulo de tenacidade.

Figura 120: Decaimento do erro durante o treinamento da RNA construída para calcular o módulo de tenacidade. 136

Figura 121: Correlação entre o $U_{t}$ medido e o $U_{t}$ calculado pela RNA para o conjunto de treinamento.

Figura 122: Correlação entre o $U_{t}$ medido e o $U_{t}$ calculado pela RNA para o conjunto de treinamento.

Figura 123: Comparação dos resultados calculados pela RNA com os valores medidos para o $U_{t}$ obtido pelo conjunto de teste do aço AISI 4140 138

Figura 124: Comparação dos resultados calculados pela RNA com os valores medidos para o $U_{t}$ obtido pelo conjunto de teste do aço AISI 4340. 138 
Figura 125: Comparação dos resultados calculados pela RNA com os valores medidos para o $\mathrm{U}_{\mathrm{t}}$ obtido pelo conjunto de teste do aço AISI $5160 \ldots \ldots \ldots \ldots \ldots . . . . .139$

Figura 126: Comparação dos resultados calculados pela RNA com os valores medidos para o $\mathrm{U}_{\mathrm{t}}$ obtido pelo conjunto de teste do aço AISI $6150 \ldots \ldots \ldots \ldots \ldots . . . . . .139$

Figura 127: Comparação dos resultados calculados pela RNA com os valores medidos para o $\mathrm{U}_{\mathrm{t}}$ obtido pelo conjunto de teste do aço AISI E52100................140

Figura 128: LRT e LE para os aços Si-Cr, S-Cr-Mo, Si-Cr-W e Si-Cr-V (NAM et al., 2000) 151 


\section{STA DE TABELAS}

Tabela 1: Propriedades mecânicas para o aço SAE 5160, temperado de $830^{\circ} \mathrm{C} \ldots . . .40$

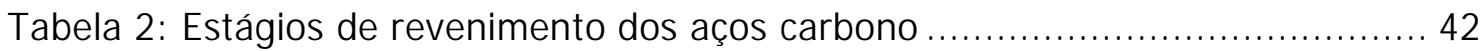

Tabela 3: Sequência dos eventos no revenimento dos aços.......................... 43

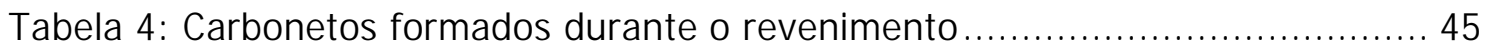

Tabela 5: Efeitos dos elementos de liga no revenimento dos aços ...................... 51

Tabela 6: Fatores para a previsão da dureza após o revenimento dos aços liga...... 59

Tabela 7: Composição química dos aços ensaiados................................ 74

Tabela 8: Fatores e níveis a serem ensaiados...................................... 75

Tabela 9: Resultados do teste da ANOVA ............................................. 80

Tabela 10:Resultados do teste de hipóteses da distribuição t. ......................... 81

Tabela 11: Dureza média do material temperado. ................................ 82

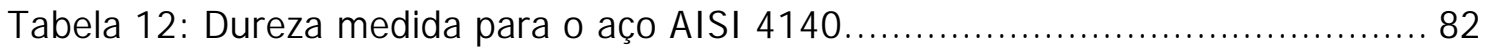

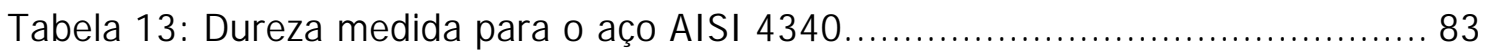

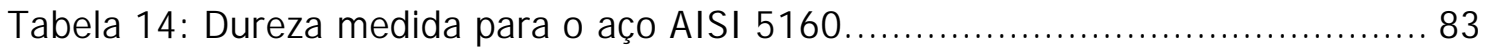

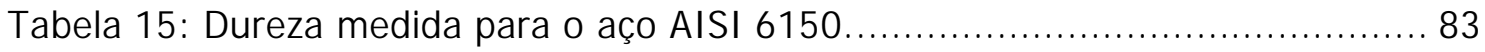

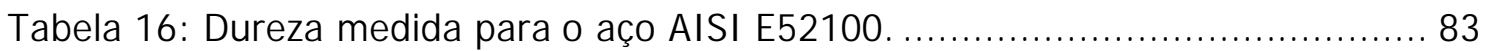

Tabela 17: Variáveis de entrada da rede projetada para modelar a dureza............ 99

Tabela 18: Parâmetros de treinamento da rede de dureza............................100

Tabela 19: ANOVA para o conjunto de teste da variável dureza......................103

Tabela 20: Variáveis de entrada da rede projetada para modelar o LRT e o LE.....107

Tabela 21: Parâmetros de treinamento da rede de LRT . ............................

Tabela 22: ANOVA para o conjunto de teste da variável LRT ..........................111

Tabela 23: ANOVA para o conjunto de teste da variável LE............................117

Tabela 24: Variáveis de entrada da rede projetada para modelar a tensão de ruptura, o módulo de resiliência e o módulo de elasticidade. 


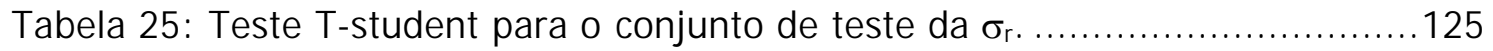

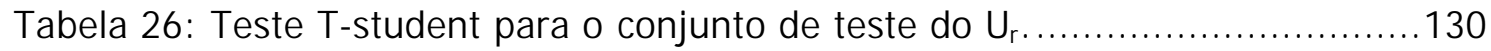

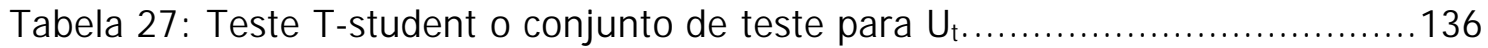

Tabela 28: Resumo das técnicas utilizadas para validar o problema...................140

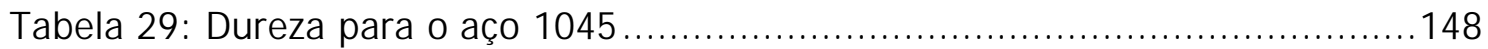

Tabela 30: Composição química ............................................... 148

Tabela 31: Dureza dos aços ligados................................................ 149

Tabela 32: Propriedades mecânicas................................................. 150

Tabela 33: Composição química .................................................... 151 


\section{LISTA DE SÍ MBOLOS E SI GLAS}

Tratamento térmico:

a $\quad$ Ferrita

$\gamma \quad$ Austenita

$\Delta \mathrm{HV}$ Incremento de dureza na escala Vickers

$\mathrm{AC}_{1}$ Temperatura crítica inferior

$\mathrm{AC}_{3}$ Temperatura crítica superior

oC Graus Celsius

c Constante da liga

ccc Cúbico de corpo centrado

cfc Cúbico de face centrada

of Graus Fahrenheit

$\mathrm{Fe}_{2} \mathrm{C}$ Carboneto $\eta$

$\mathrm{Fe}_{2,2} \mathrm{C}$ Carboneto $\chi$ ou Hägg

$\mathrm{Fe}_{2,4} \mathrm{C}$ Carboneto $\varepsilon$

$\mathrm{Fe}_{3} \mathrm{C}$ Cementita ou carboneto $\theta$

FMR Fragilização da martensita revenida

$h \quad$ Energia de ativação

HRB Dureza na escala Rockwell B

HRC Dureza na escala Rockwell C

HV Dureza na escala Vickers

KHN Dureza na escala Knoop

$M_{50}$ Temperatura quando há 50\% de transformação martensítica

$M_{90}$ Temperatura quando há $90 \%$ de transformação martensítica

$\mathrm{M}_{\mathrm{f}} \quad$ Temperatura final da transformação martensítica

$M_{i} \quad$ Temperatura de início da transformação martensítica

$P \quad$ Parâmetro de revenimento

Q Variável função da dureza

$\mathrm{R} \quad$ Constante ideal dos gases

T Temperatura

t Tempo 


$$
\begin{array}{cl}
\text { tcc } & \text { Tetragonal de corpo centrado } \\
\text { TTT transformação-tempo-temperatura }
\end{array}
$$

Propriedades mecânicas:

$\begin{array}{ll}\varepsilon & \text { Deformação } \\ \varepsilon_{\mathrm{e}} & \text { Deformação quando acontece LE } \\ \varepsilon_{f} & \text { Deformação final } \\ \sigma & \text { Tensão } \\ \mathrm{E} & \text { Módulo de elasticidade } \\ \mathrm{LE} & \text { Limite de escoamento } \\ \text { LRT } & \text { Limite de resistência à tração } \\ U_{\mathrm{r}} & \text { Módulo de resiliência } \\ U_{\mathrm{t}} & \text { Módulo de tenacidade }\end{array}$

Redes neurais:

$\alpha \quad$ Parâmetro de regularização para o a SSW

$\beta \quad$ Parâmetro de regularização para o erro

$\eta \quad$ Taxa de aprendizagem

$v \quad$ Vetor da soma do vetor de entrada mais bias

a Saída desejada

b Bias

$g$ Gradiente

LM Levenberg-Marquardt

MLP Perceptron de múltiplas camadas

MSE Média dos erros quadráticos

$s \quad$ Sensibilidade

SSE Soma dos erros quadráticos 


$\begin{array}{ll}\text { SSW } & \text { Soma dos pesos quadráticos } \\ t & \text { Saída da rede } \\ w & \text { Pesos } \\ x & \text { Vetor dos bias e pesos } \\ x_{n} & \text { Dado normalizado } \\ y & \text { Saída do neurônio }\end{array}$

Análise estatística:
$\alpha \quad$ Nível de significância
$\mu_{1} \quad$ Média da amostra 1
$\mu_{2} \quad$ Média da amostra 2
$v \quad$ Graus de liberdade
a Coeficiente angular
b Intercepto-y
F Distribuição de Fisher-Snedecor
H Hipótese
$\mathrm{H}_{0} \quad$ Hipótese nula
$\mathrm{H}_{\mathrm{A}} \quad$ Hipótese alternativa
MS Média dos quadrados
R Coeficiente de correlação
S Desvio padrão
SS Soma dos quadrados
$T$ Distribuição t-student
$\bar{x} \quad$ Média da variável $\mathrm{x}$
$\bar{y} \quad$ Média da variável y 


\section{SUMÁRIO}

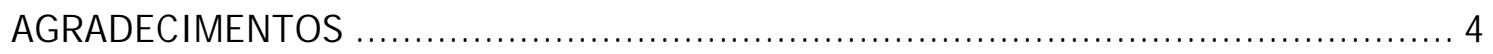

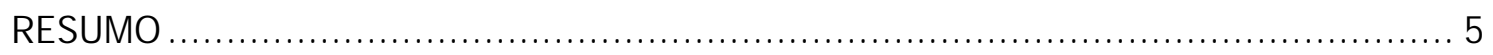

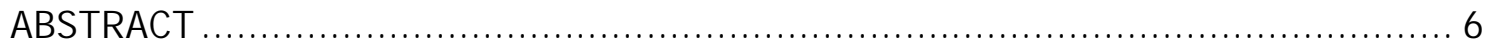

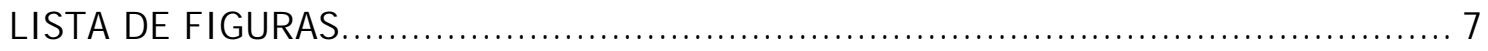

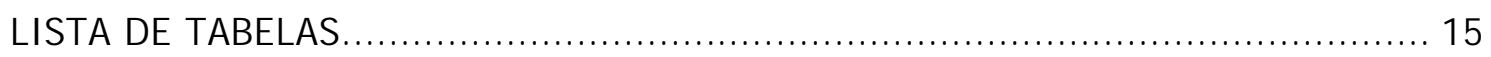

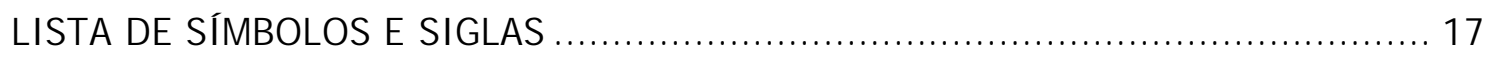

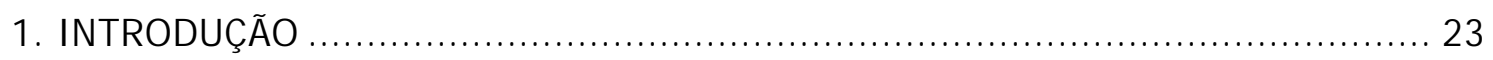

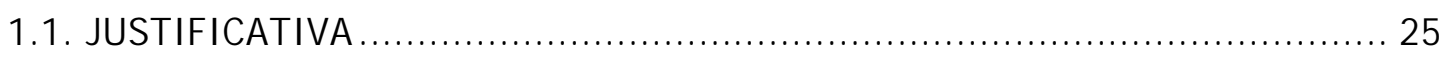

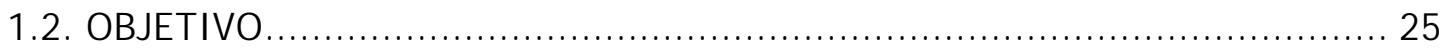

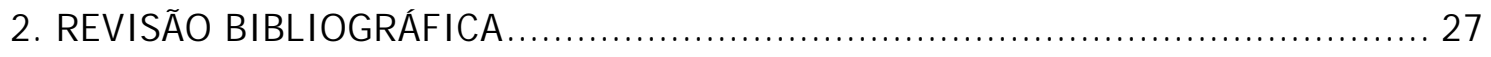

2.1. DIAGRAMA FERRO-CARBONO E DIAGRAMA TTT .................................. 27

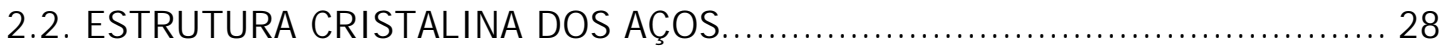

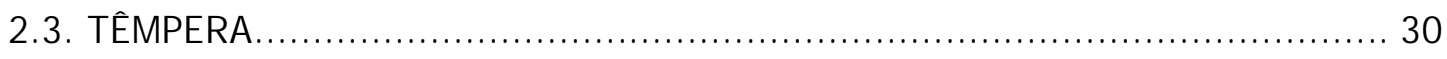

2.4. REVENIMENTO

2.4.1. Variações nas propriedades mecânicas ............................................. 33

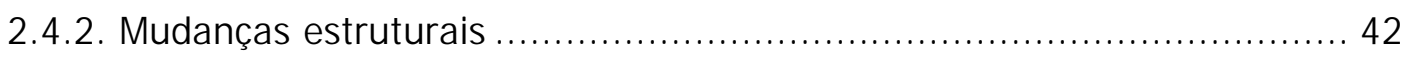

2.4.2.1. Estágios de revenimento nos aços carbono................................. 42

2.4.2.2. Nucleação e crescimento dos carbonetos de liga ........................... 46

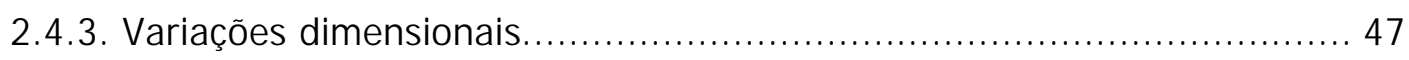

2.4.4. Efeito da quantidade de carbono.............................................. 48

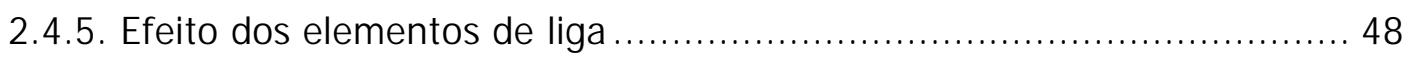

2.4.6. Fenômenos de fragilização......................................................... 50 


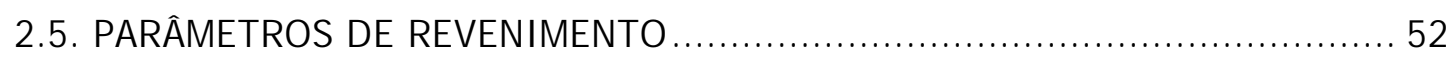

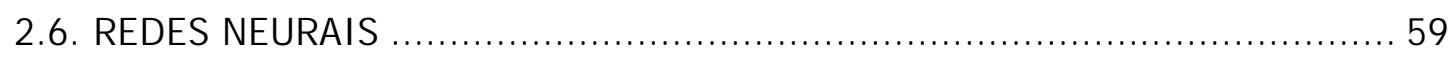

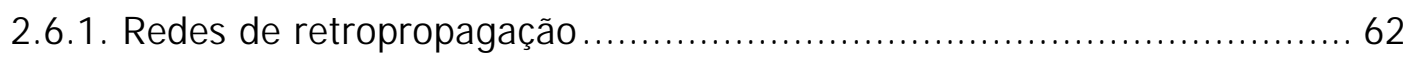

2.6.2. Algoritmo de Levenberg-Marquardt .............................................. 67

2.6.3. Pré-processamento dos dados de entrada........................................ 71

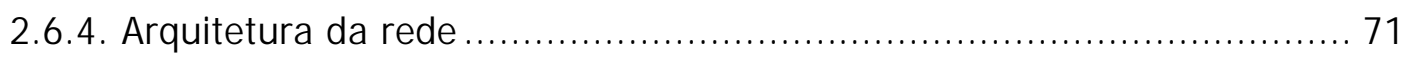

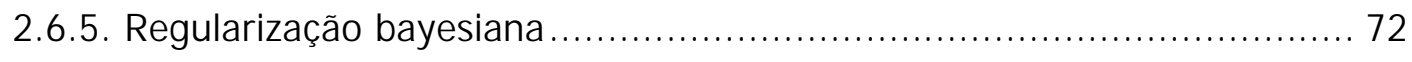

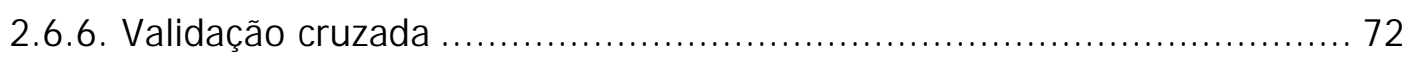

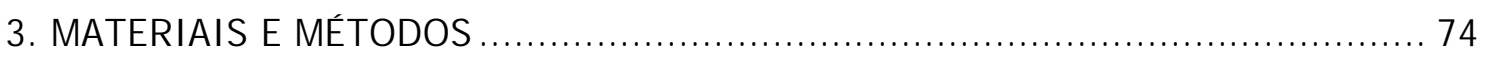

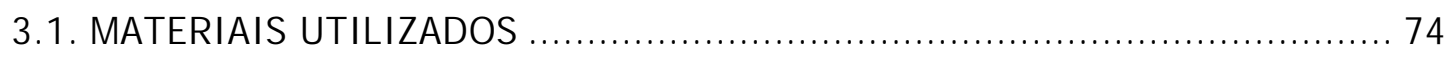

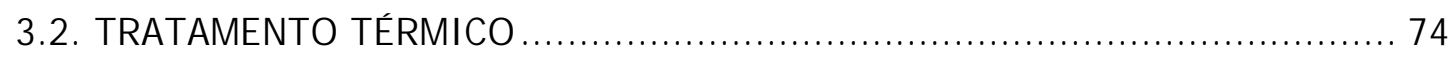

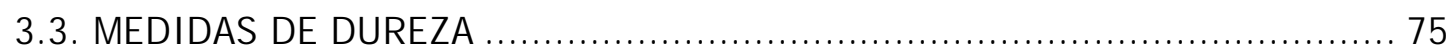

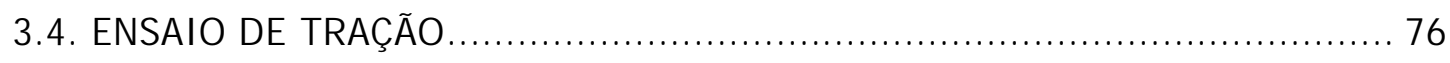

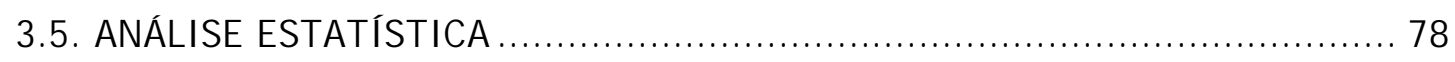

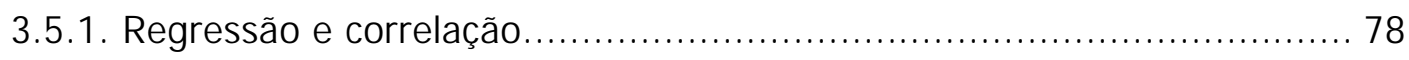

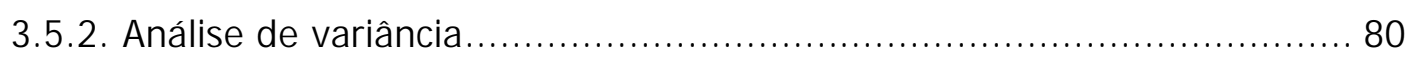

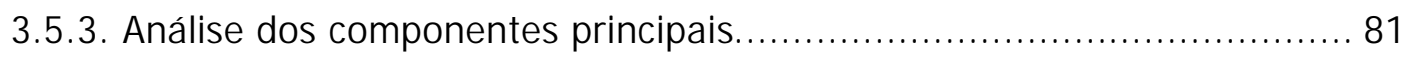

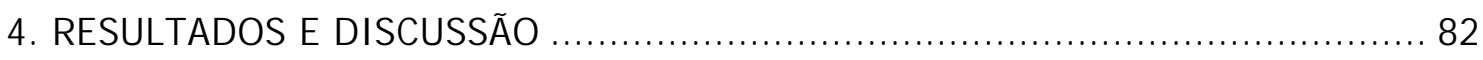

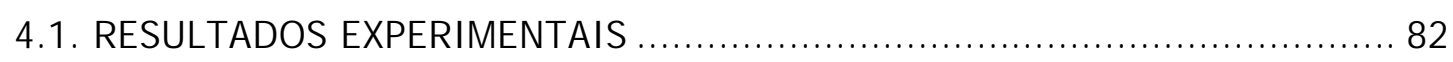

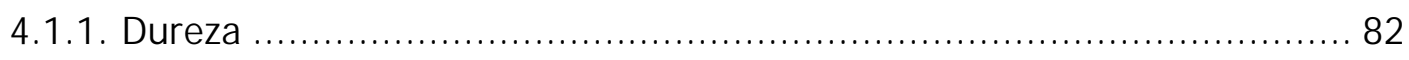

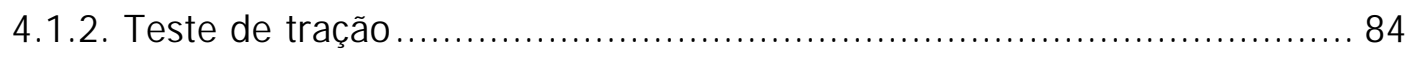

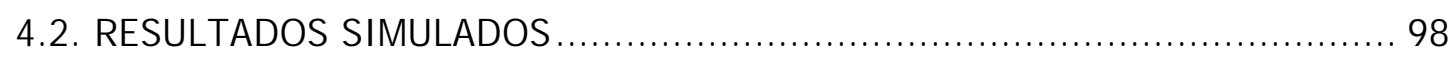

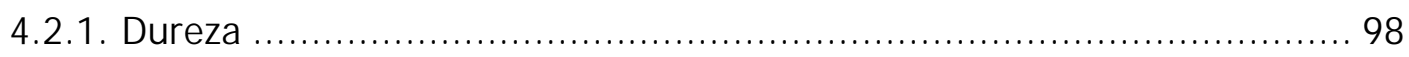

4.2.2. Limite de Resistência à tração ...................................................107 


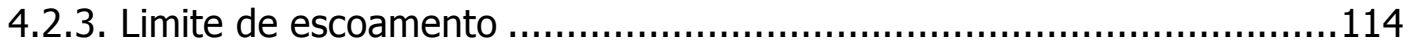

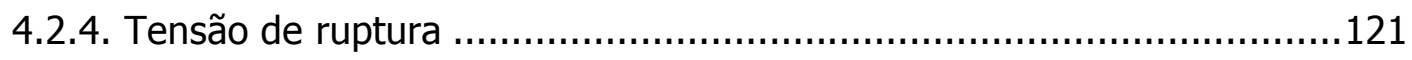

4.2.5. Módulo de resiliência...................................................................128

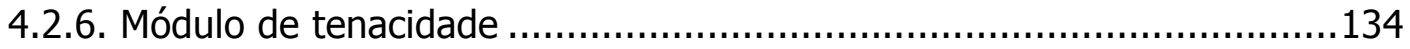

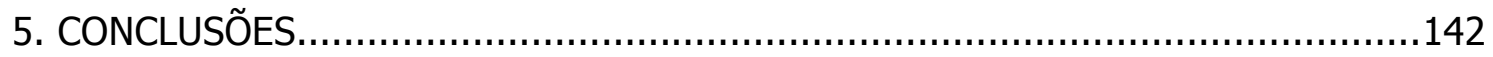

6. SUGESTÕES PARA TRABALHOS FUTUROS …............................................143

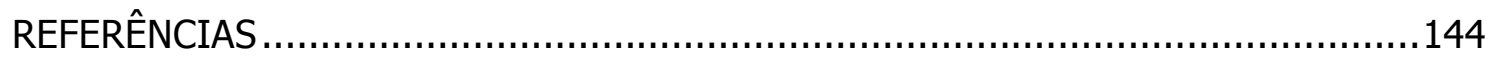

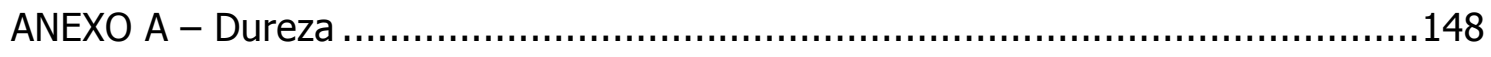

ANEXO B - Limite de resistência à tração e Limite de escoamento .......................150 


\section{I NTRODUÇÃO}

Os tratamentos térmicos são processos industriais que têm por objetivo modificar as propriedades mecânicas dos aços. Estes processos constituem em aquecer o componente metálico até uma temperatura adequada, mantê-lo nesta temperatura por um período de tempo e em seguida resfriar em condições apropriadas. 0 objetivo desta técnica é alterar as propriedades mecânicas através da modificação microestrutural do aço.

Por exemplo, não seria recomendável utilizar um componente temperado, porque sua estrutura martensítica apesar de dura é extremamente frágil. Desta forma a modificação de suas propriedades mecânicas seria feita através de um tratamento térmico, abaixo da temperatura crítica inferior, denominado revenimento. Honeycombe e Bhadeshia (1995) lembram que este é um dos tratamentos térmicos mais antigos aplicado aos aços, porém o entendimento dos fenômenos nele envolvidos é bem recente.

A martensita é essencialmente uma matriz ferrosa supersaturada em carbono que, durante o revenimento, rejeita o carbono na forma de fases de carbonetos finamente dispersos. Honeycombe e Bhadeshia (1995) descrevem o resultado final do revenimento como uma fina dispersão de carbonetos de ferro em uma matriz ferrítica a qual muitas vezes ostenta pouca similaridade estrutural em relação martensita temperada.

A execução do processo de revenimento em si é muito simples, pois consiste apenas em introduzir o componente metálico no forno em ambiente com uma temperatura adequada, por certo período de tempo. No entanto a interação das variáveis: tempo e temperatura; somadas à composição química do aço é o que determinará as propriedades mecânicas do aço revenido.

Tal simplicidade de execução do processo se contrasta com a complexidade dos fenômenos envolvidos na mudança microestrutural do aço durante 0 revenimento. Atualmente o controle do processo de revenimento praticamente não existe ou se dá pelo uso de alguns parâmetros anteriormente estabelecidos. Tais parâmetros permitem a escolha adequada do tempo e da temperatura a serem utilizados para atingir determinada dureza. 
Dentre os vários parâmetros de revenimento existentes não há dúvidas que 0 mais famoso e relevante seja o de Hollomon e Jaffe (1945). A grande contribuição destes pesquisadores foi perceber que diferentes combinações de tempo e temperatura produziam a mesma dureza como mostra o desenho esquemático da Figura 1. Por eles foi desenvolvido um parâmetro de revenimento, o qual correlaciona o tempo e a temperatura de revenimento à dureza obtida e, que posteriormente foi sendo adaptado e modificado por outros autores como será descrito mais adiante.

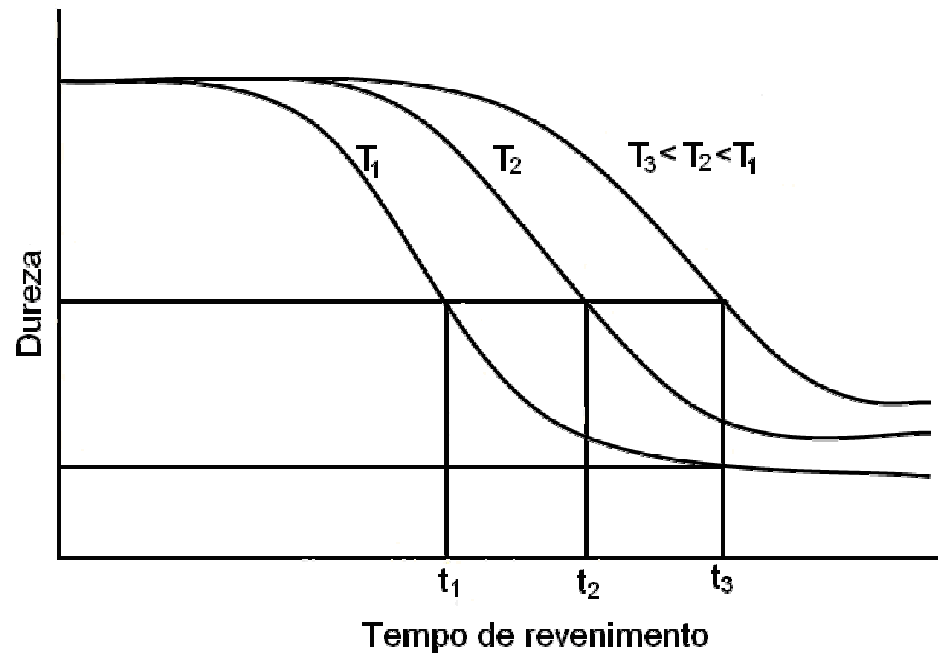

Figura 1: Relação entre a dureza e o tempo e a temperatura de revenimento (BROOKS, 1996).

Certamente o parâmetro citado acima é útil para quantificar o tempo e temperatura de revenimento, e de fato algumas indústrias o utilizam, no entanto ele ainda apresenta algumas limitações.

A principal limitação deste parâmetro se deve ao fato de que cada liga precisa de um parâmetro próprio, o que torna sua utilização pouco prática, além disso, estes parâmetros consideram apenas a dureza. Por este motivo se justifica a busca por outras soluções. Além disso, as variáveis dos processos de manufatura em metalurgia são complexas e muitas vezes difíceis de serem coletadas. A primeira barreira a superar durante a modelagem de processos dos aços é adquirir uma base de dados considerável. As indústrias que manufaturam estas ligas (ou aços) tendem a classificar suas variáveis de processo por razões óbvias. E por esta razão é muito 
difícil conseguir um conjunto de dados ou informações que consista de detalhes, tais como micro-inclusões ou trincas. É importante lembrar que algumas propriedades são influenciadas por fatores intrínsecos como inclusões, segregações, tamanho de grão, entre outros, que podem variar de corrida para corrida. Como as relações entre estas saídas e entradas são de natureza não-linear e extremamente complexa, fica impossível desenvolvê-las na forma matemática. Técnicas como regressão linear não seria apropriada para uma modelagem acurada de dados que exibem uma quantidade considerável de ruído, como neste caso. A análise de regressão para modelar dados não-lineares necessita do uso de uma equação como uma tentativa de transformar os dados para a forma linear (Reddy et al., 2005). Isto representaria uma aproximação que inevitavelmente introduziria um nível de erro significativo. Similarmente, não é fácil usar métodos estatísticos para relacionar múltiplas entradas a múltiplos processos de saída.

0 método das redes neurais artificiais (RNAs) por outro lado, foi identificado como uma forma apropriada de superar tais dificuldades. As RNAs são modelos matemáticos e algoritmos que imitam o sistema nervoso dos animais. Singh et al. (1998) descrevem que, a princípio, as RNAs podem generalizar uma quantidade limitada de dados de treinamento tendendo a relações funcionais. Embora muitas arquiteturas de redes e algoritmos de treinamento estejam disponíveis, as redes com aprendizagem direta por retro-propagação são as mais comumente utilizadas. Além disso, nas últimas décadas o uso das RNAs na engenharia de materiais tem crescido constantemente.

\subsection{J USTI FI CATI VA}

Uma vez que não há um consenso acerca do melhor parâmetro de revenimento e que cada um deles apresenta uma série de limitações, se justifica a busca por novas soluções.

\subsection{OBJ ETIVO}

O objetivo deste trabalho é projetar redes neurais capazes de prever a dureza, o limite de resistência à tração, o limite de escoamento, o módulo de resiliência, a tensão de ruptura e o módulo de tenacidade para aços carbono para beneficiamento 
revenidos em diversas condições. 0 modelo desenvolvido poderá abranger mais tipos de aços e outras propriedades que os parâmetros atuais, além de proporcionar maior praticidade à execução desta tarefa. 


\section{REVISÃO BI BLIOGRÁFICA}

\subsection{AGRAMA FERRO-CARBONO E DI AGRAMA TTT}

O diagrama de fase ferro-carbono (Fe-C), mostrado na Figura 2, é a representação gráfica das fases presentes em determinada composição e temperatura. Segundo Krauss (1990) é neste diagrama onde todos os tratamentos térmicos se baseiam, pois ele define as regiões de temperatura e teor de carbono onde as fases são estáveis. No entanto ele ressalta que este diagrama deve ser apenas um guia, uma vez que a maioria dos aços contém outros elementos que modificam as posições de equilíbrio onde as fases são estáveis.

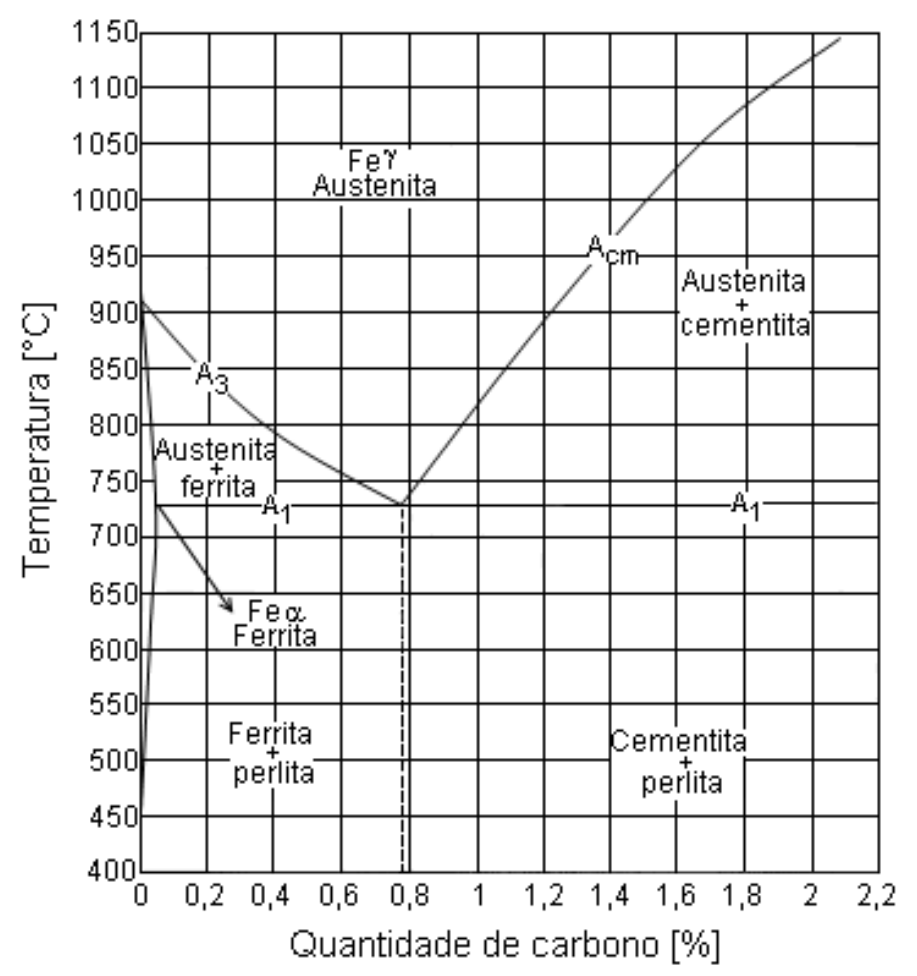

Figura 2: Diagrama ferro-carbono (AMERICAN SOCIETY FOR METALS, 1998).

Os aços são ligas de ferro, carbono e outros elementos. O ferro é o elemento que entra em maior proporção. A quantidade de carbono não ultrapassa 2\%, porém este elemento é o que mais influencia nas propriedades e posições de equilíbrio. Krauss (1990) destaca que alguns elementos, como o manganês e o níquel, podem aumentar a área onde a austenita é estável. Já o silício, o cromo e o nióbio 
estabilizam a fase ferrítica. Os carbonetos são formados por cromo, titânio, nióbio ou molibdênio, desde que estejam presentes em quantidade suficiente.

O diagrama de transformação isotérmica, que também é conhecido como diagrama TTT (transformação-tempo-temperatura), pode ser observado na Figura 3. Em uma transformação isotérmica a temperatura é mantida constante enquanto se varia o tempo. Este procedimento torna a cinética de transformação mais fácil de ser analisada para determinada temperatura. É importante ressaltar que alguns fatores influenciam diretamente na posição das curvas de inicio e fim de transformação, como por exemplo, a quantidade de carbono, o tamanho dos grãos, a presença dos elementos de liga e a homogeneidade da austenita.

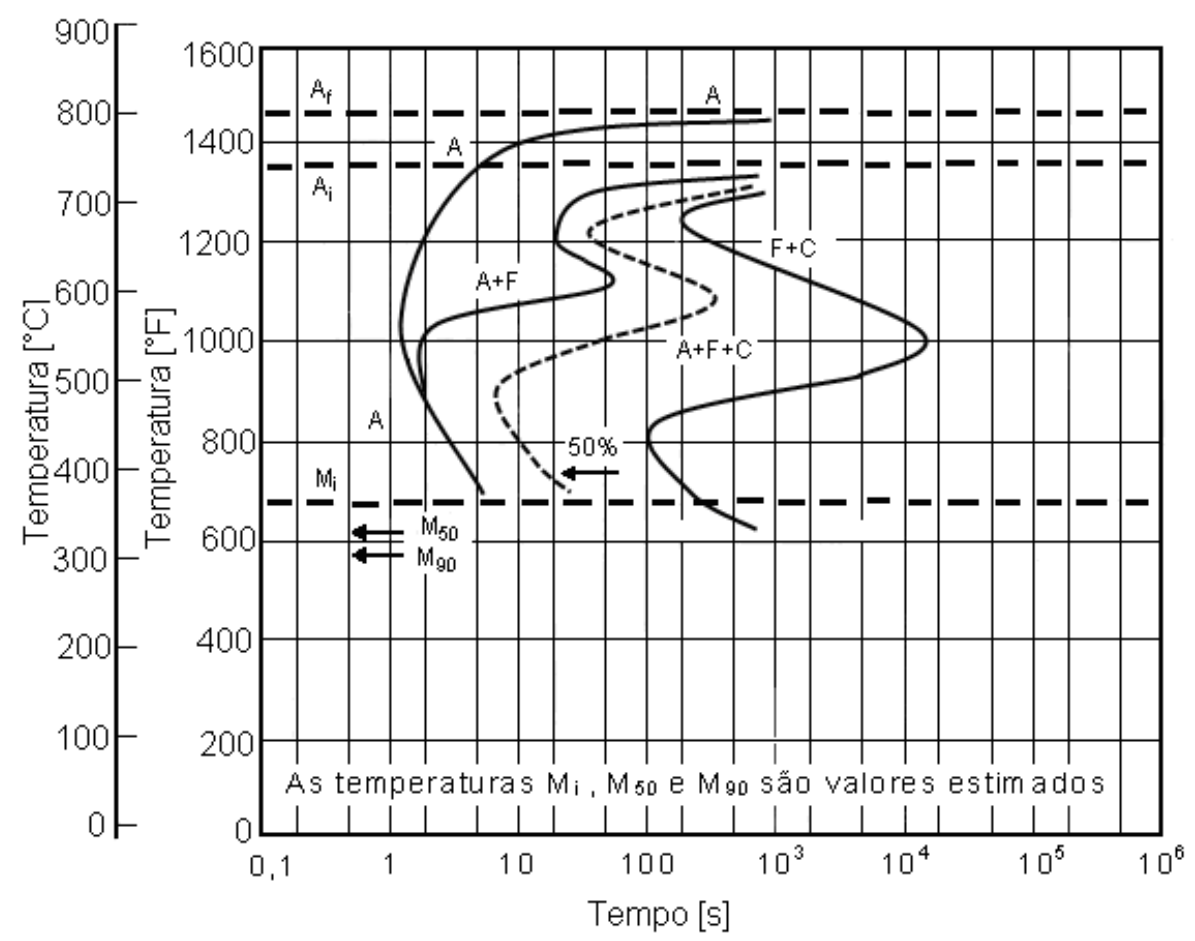

Figura 3: Diagrama TTT para o aço SAE 4130 (AMERICAN SOCIETY FOR METALS, 1998).

\subsection{ESTRUTURA CRISTALI NA DOS AÇOS}

As fases dos metais no estado sólido são sempre cristalinas. Quando um aço é lentamente resfriado, sua estrutura cristalina vai da austenita $(\gamma)$, uma fase mais densa, (cúbica de face centrada, cfc), para a ferrita $(\alpha)$, uma fase de menor densidade, (cúbica de corpo centrada, ccc). 
O objetivo da têmpera é produzir uma estrutura metaestável que, no caso dos aços, é a martensita. Esta apresenta uma estrutura tetragonal de corpo centrado (tcc) e é produzida a partir da austenita. A Figura 4 ilustra as estruturas cristalinas citadas.
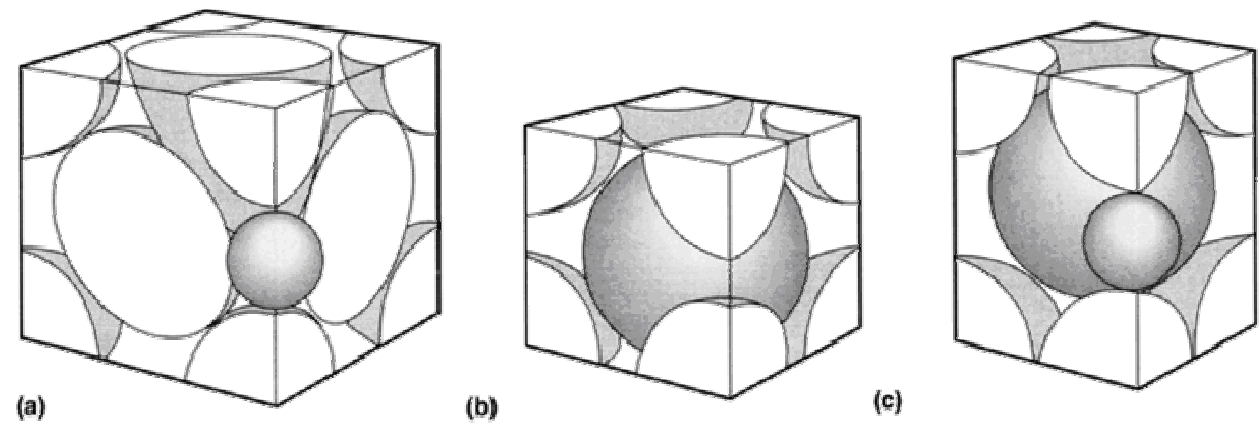

Figura 4: Estruturas cristalinas: (a) austenita, cfc, (b) ferrita, ccc, e (c) martensita, tCC (AMERICAN SOCIETY FOR METALS, 1998).

A martensita é formada sob condições não isotérmicas, sua morfologia varia em função da composição química do aço, mas seu mecanismo de formação é por um processo sem difusão, onde mudanças rápidas de temperatura causam deslocamentos por cisalhamento em certas regiões do cristal original sem grande movimentação de átomos. A transformação depende apenas da temperatura: começa a se formar na temperatura de início de transformação martensítica $\left(\mathrm{M}_{\mathrm{i}}\right)$ e termina quando o metal atinge a temperatura final de transformação martensítica $\left(\mathrm{M}_{\mathrm{f}}\right)$. Por isso a necessidade de se resfriar rapidamente 0 aço, pois a austenita não pode se transformar em outras fases. As temperaturas $M_{i}$ e $M_{f}$ dependem $d a$ composição química do metal, e estão em torno de 300 e $200^{\circ} \mathrm{C}$ respectivamente. A temperatura $M_{i}$ pode ser estimada pela relação empírica abaixo:

$$
M_{i}=539-423(\% C)-30,4(\% M n)-17,7(\% \mathrm{Ni})-12,1(\% \mathrm{Cr})-7,5(\% \mathrm{Mo})
$$

A cementita é o carboneto de ferro, $\mathrm{Fe}_{3} \mathrm{C}$, formado quando a solubilidade de carbono na ferrita e na austenita é excedida, se cristalizando na forma de um paralelepípedo ortorrômbico, como ilustra a Figura 5. 


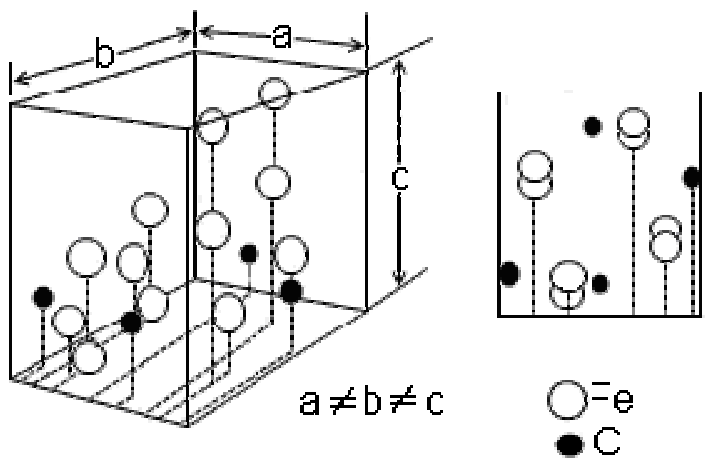

Figura 5: Esquema da estrutura ortorrômbica da cementita (AMERICAN SOCIETY FOR METALS, 2003).

\subsection{TÊMPERA}

Krauss (1990) define austenitização como sendo a formação da austenita pelo aquecimento de uma liga ferrosa até uma temperatura ligeiramente mais elevada que a crítica superior $\left(\mathrm{AC}_{3}\right)$.

A têmpera por sua vez consiste em resfriar o aço rapidamente após a austenitização, em um meio apropriado, com o objetivo de se obter a tão desejada martensita. Tal estrutura confere dureza e resistência à peça tratada. Os meios de resfriamento variam de severidade e os mais comumente utilizados são: água, óleo, soluções poliméricas e soluções salinas, apresentando diferentes severidades (TOTTEN; BATES e CLINTON, 1993).

Dependendo do teor de carbono, a martensita pode apresentar dois tipos de morfologia: ripas e placas. A Figura 6 relaciona a morfologia da martensita à quantidade de carbono. Segundo Krauss (1990), a martensita tipo ripas é formada nos aços de baixo carbono, são ripas longas e finas que se formam lado a lado, alinhadas paralelamente entre si. A martensita tipo placas se desenvolve nos aços de alto carbono. Com esta estrutura os grãos da martensita adquirem uma aparência em formato de agulha ou placas e é comum a presença da austenita retida (CALLISTER,2002). Nos aços de médio carbono podem coexistir os dois tipos de martensita. 


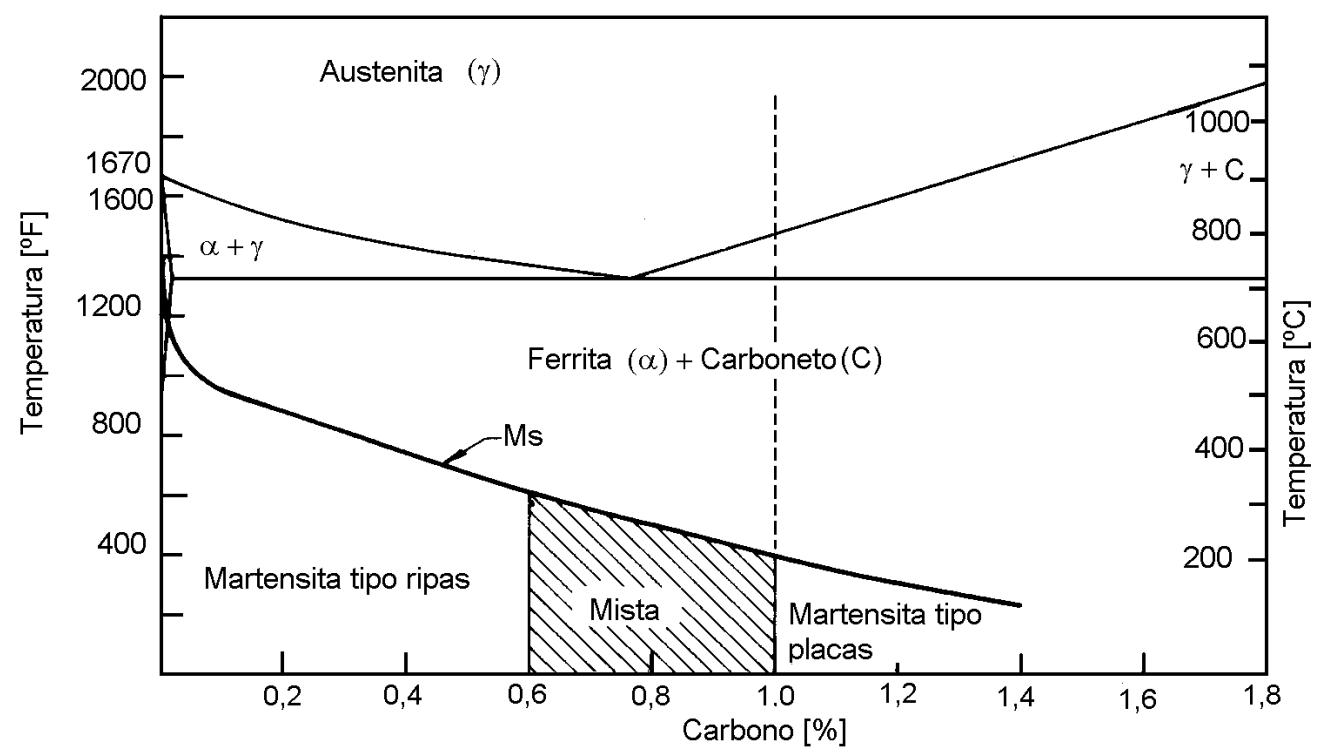

Figura 6: Intervalos de formação da martensita tipo ripas e tipo placas (KRAUSS, 1990).

Todo este processo provoca gradientes térmicos altíssimos, originando assim tensões térmicas na peça temperada. Além das tensões térmicas o processo de transformação da martensita a partir da austenita também gera uma série de tensões de transformação. A soma destas tensões é definida como tensões residuais de têmpera.

Assim, a martensita obtida pela têmpera é uma estrutura bastante dura e frágil. A maior dificuldade em se usar aços temperados consiste exatamente na baixa tenacidade e na alta concentração de tensões da martensita. Segundo Krauss (1990), esta fragilidade se deve às distorções no reticulado causadas pelos átomos de carbono retidos nos sítios octaédricos da martensita (Figura 7), à segregação das impurezas para os contornos de grão da austenita, à formação de carbonetos durante a têmpera e às tensões residuais de têmpera. Para aliviar estas tensões e melhorar a tenacidade do material temperado se faz necessário outra etapa de tratamento térmico. 0 processo adequado pra este fim é denominado revenimento e será descrito na próxima seção. 


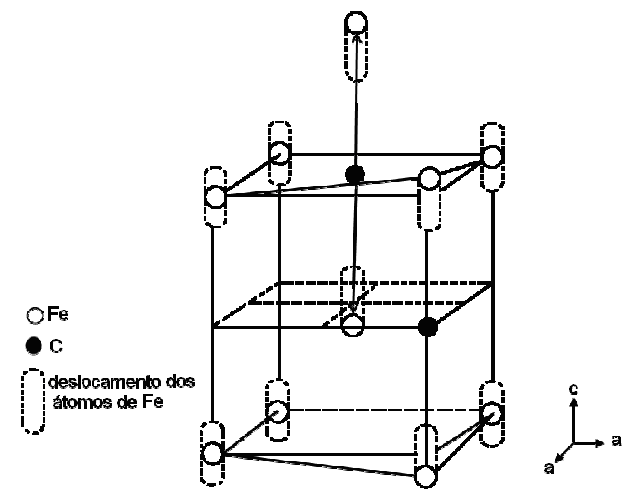

Figura 7: Deslocamentos do átomo de ferro devido aos átomos de carbono na martensita (COHEN, 1962).

\subsection{REVENI MENTO}

Brooks (1996) descreve que na maioria das aplicações onde uma dureza alta é necessária, a peça temperada é aquecida abaixo da temperatura crítica inferior (ou seja, abaixo de $723^{\circ} \mathrm{C}$ ou da temperatura $\mathrm{Ac}_{1}$ ) para que a martensita se converta em uma estrutura que apresente uma combinação ótima de dureza (resistência) e tenacidade. Este tratamento é denominado revenimento e seu principal objetivo é melhorar a tenacidade e aliviar as tensões do componente temperado. A estrutura formada é denominada martensita revenida, a qual se caracteriza pela dispersão de partículas finas de carboneto, normalmente de ferro, em uma matriz ferrítica. A Figura 8 ilustra o tradicional esquema de tratamento térmico onde a têmpera é seguida pelo revenimento.

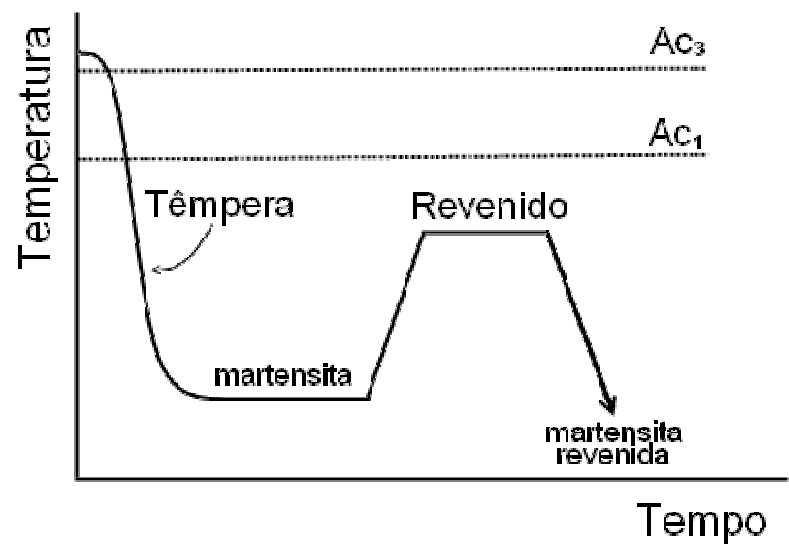

Figura 8: Tratamento térmico dos aços (Adaptado de AMERICAN SOCIETY FOR METALS, 1998). 
O mecanismo fundamental responsável pelo revenimento é um processo termo-ativado; onde as variáveis, tempo e temperatura, devem ser escolhidas com parcimônia a fim de se obter a combinação desejada entre resistência e ductilidade. Revenir além do necessário pode implicar na perda de resistência em um grau que o componente se torne inapropriado para a função proposta.

\subsubsection{Variações nas propriedades mecânicas}

O efeito da temperatura e do tempo de revenimento na dureza é mostrado pelas Figuras 9 e 10. Na Figura 9 se pode observar a dureza como temperada para os aços carbono AISI 1045 e AISI 1026 e a rapidez em que a martensita se decompõe numa estrutura de ferrita e carboneto de ferro, que se reflete pelo decréscimo da dureza em apenas 10 minutos de revenimento a $204^{\circ} \mathrm{C}$. Segundo Brooks (1996) a redução da dureza em função do acréscimo da temperatura de revenimento está associada ao coalescimento dos carbonetos. Conclui-se também que quanto maior o teor de carbono, maior a dureza, fato atribuído à presença de uma grande quantidade de carboneto de ferro. Para aços de até $0,2 \% C$ não ocorre a precipitação de carbonetos na forma de clusters que se posicionam nas discordâncias.

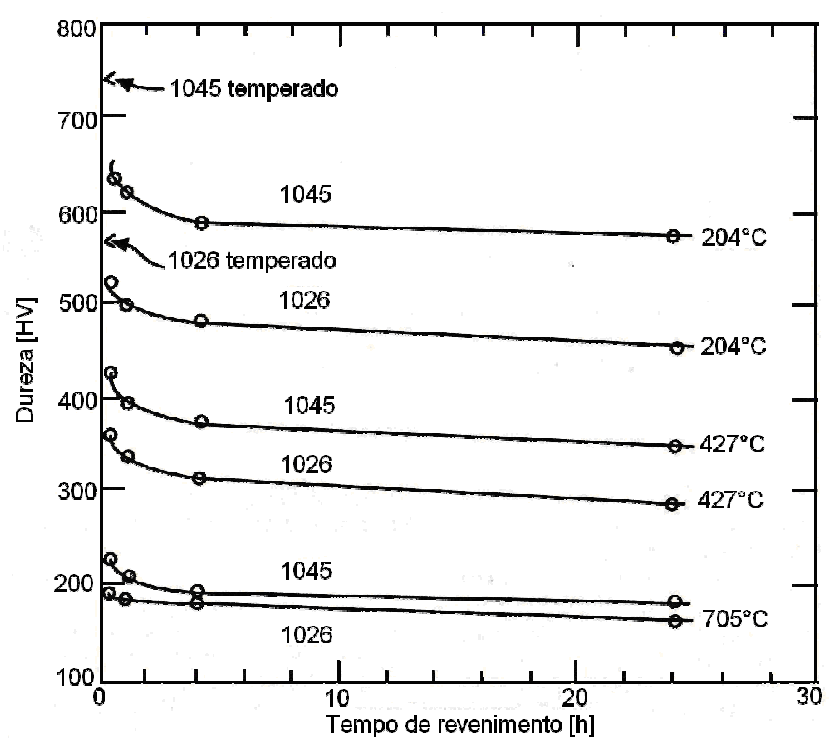

Figura 9: Efeito do tempo e temperatura de revenimento na dureza (GRANGE e BAUGHMAN, 1956). 
A Figura 10 mostra os dados obtidos para um aço de alto carbono (AISI W1), onde se observa que quanto maior o tempo de revenimento, menor a dureza, especialmente nas temperaturas mais altas. Nesta figura também se nota um discreto aumento da dureza para os aços revenidos a 100 e $150^{\circ} \mathrm{C}$.

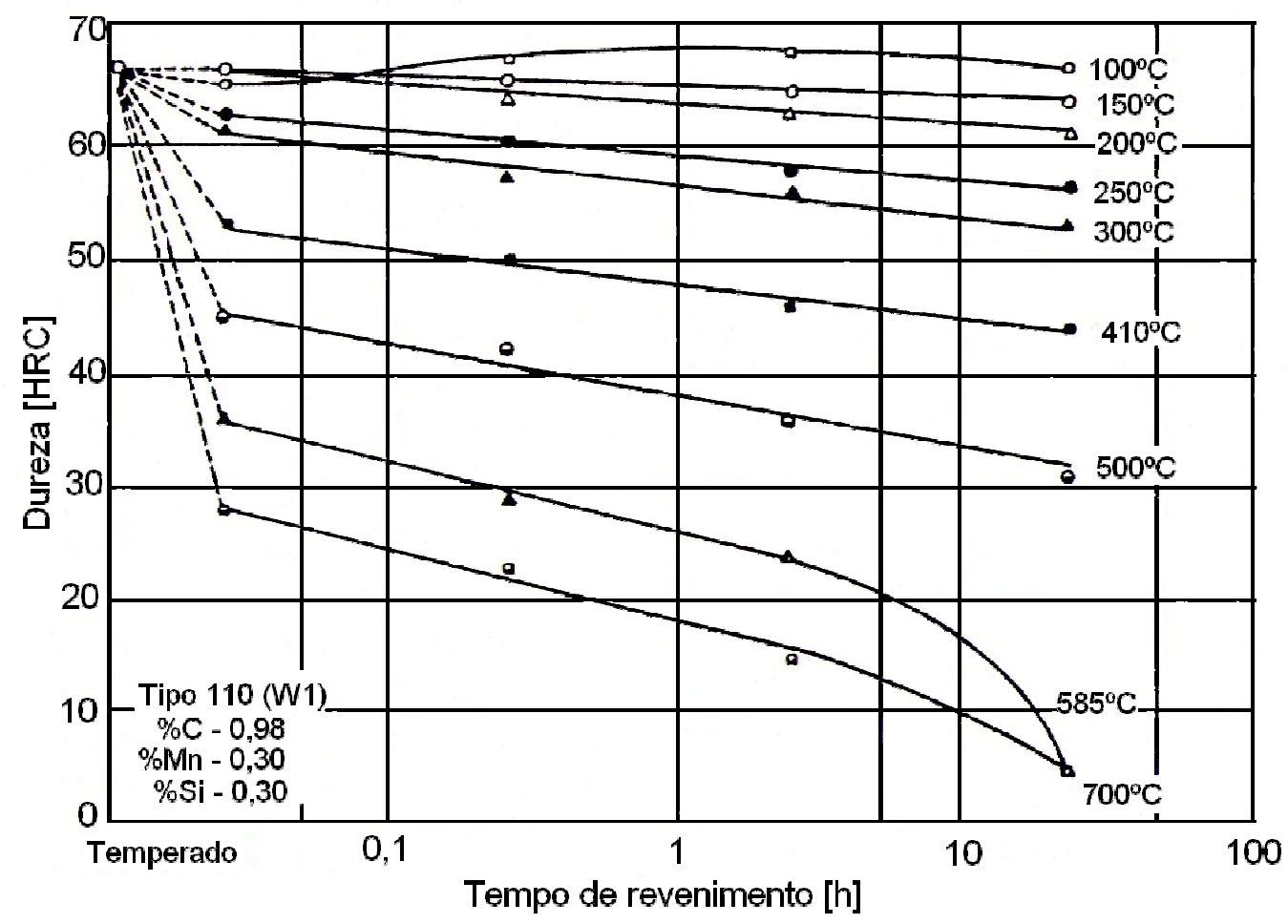

Figura 10: Efeito do tempo e da temperatura na dureza do aço W1 (Adaptado de HOLLOMON e JAFFE, 1945).

A Figura 11 mostra explicitamente que realmente há um aumento da dureza após o revenido em relação à dureza como temperada para um aço Fe-1,22C. Tratase de um efeito comum nos aços de alto carbono revenidos em temperaturas mais baixas. Krauss (1990) explica que este acréscimo se deve à precipitação de partículas de carbonetos de transição muito finos concentrados dentre as placas de martensita. 


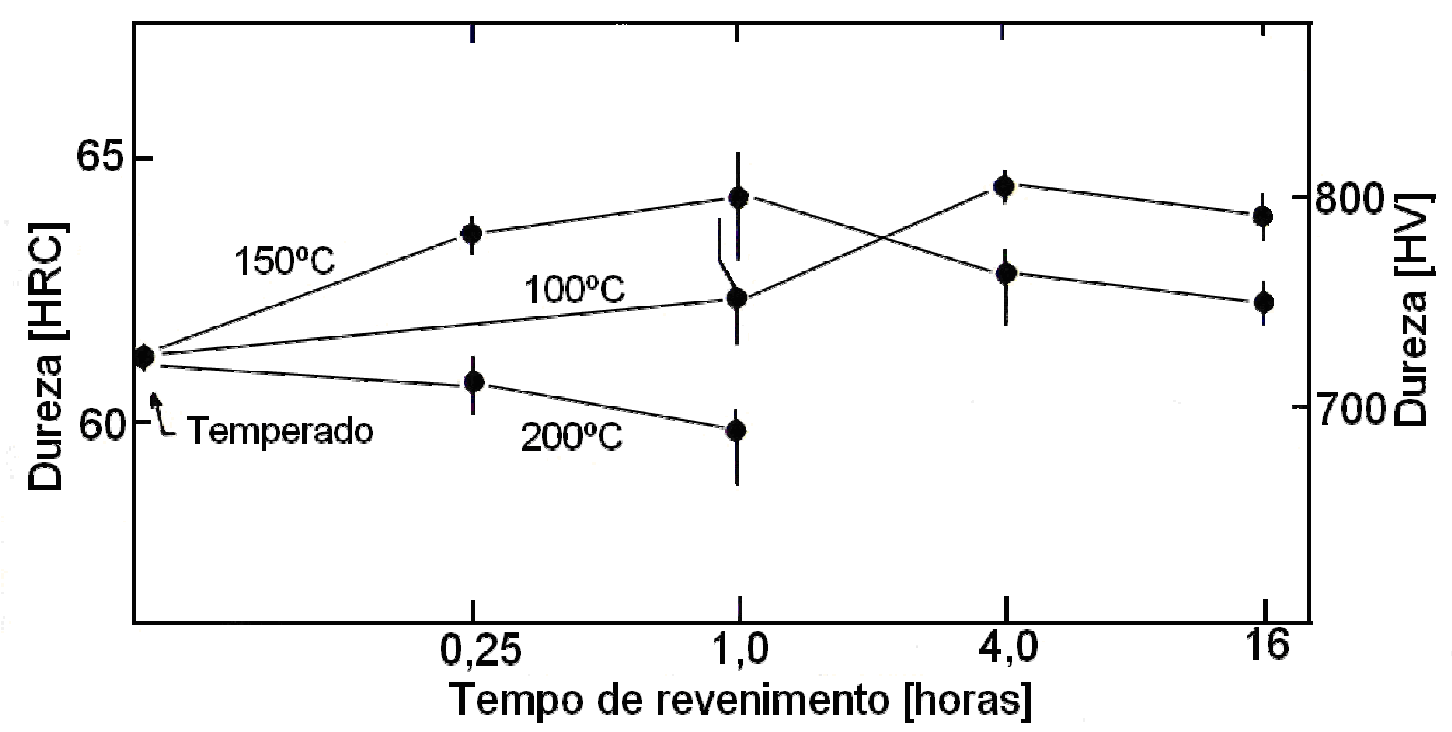

Figura 11: Dureza como função do tempo para três temperaturas de revenimento de um aço Fe-1,2C (KRAUSS, 1990).

O efeito de tempos curtos de revenimento pode ser observado na Figura 12, onde já se nota uma redução mensurável de dureza em apenas 0,3 s de tratamento, o que vem a ressaltar a rapidez da difusão do carbono na martensita.

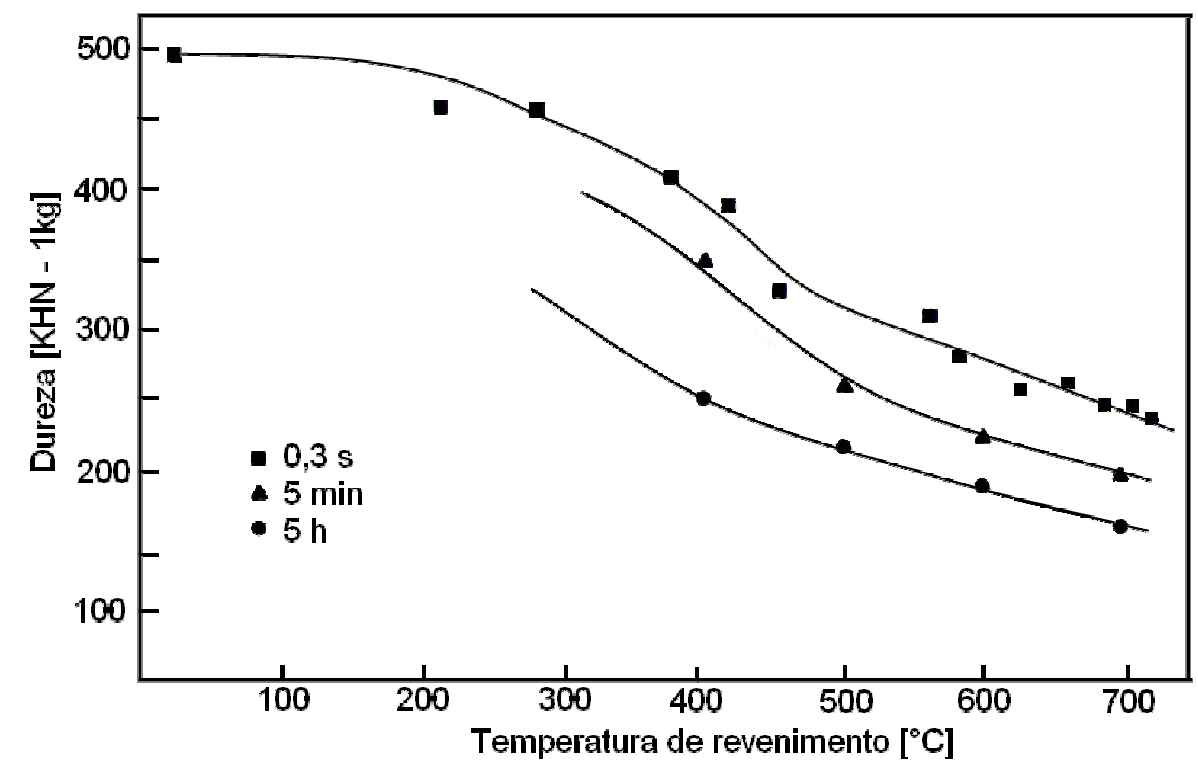

Figura 12: Microdureza em função da temperatura de revenimento para um aço com 0,2\% de carbono (KRAUSS, 1990). 
O efeito dos elementos de liga na dureza do revenido pode ser examinado nas curvas de revenimento dos aços SAE 1040 e SAE 2340 da Figura 13. As duas curvas apresentam o mesmo comportamento e contêm a mesma quantidade de carbono, no entanto, o que as difere é o maior nível de dureza alcançado pelo aço ligado. Segundo Brooks (1996), muitas ligas podem sofrer um aumento proeminente da dureza entre 500 e $600^{\circ} \mathrm{C}$, como ilustra a Figura 14. Este aumento é denominado endurecimento secundário e, trata-se de um efeito bem pronunciado e importante para os aços altamente ligados.

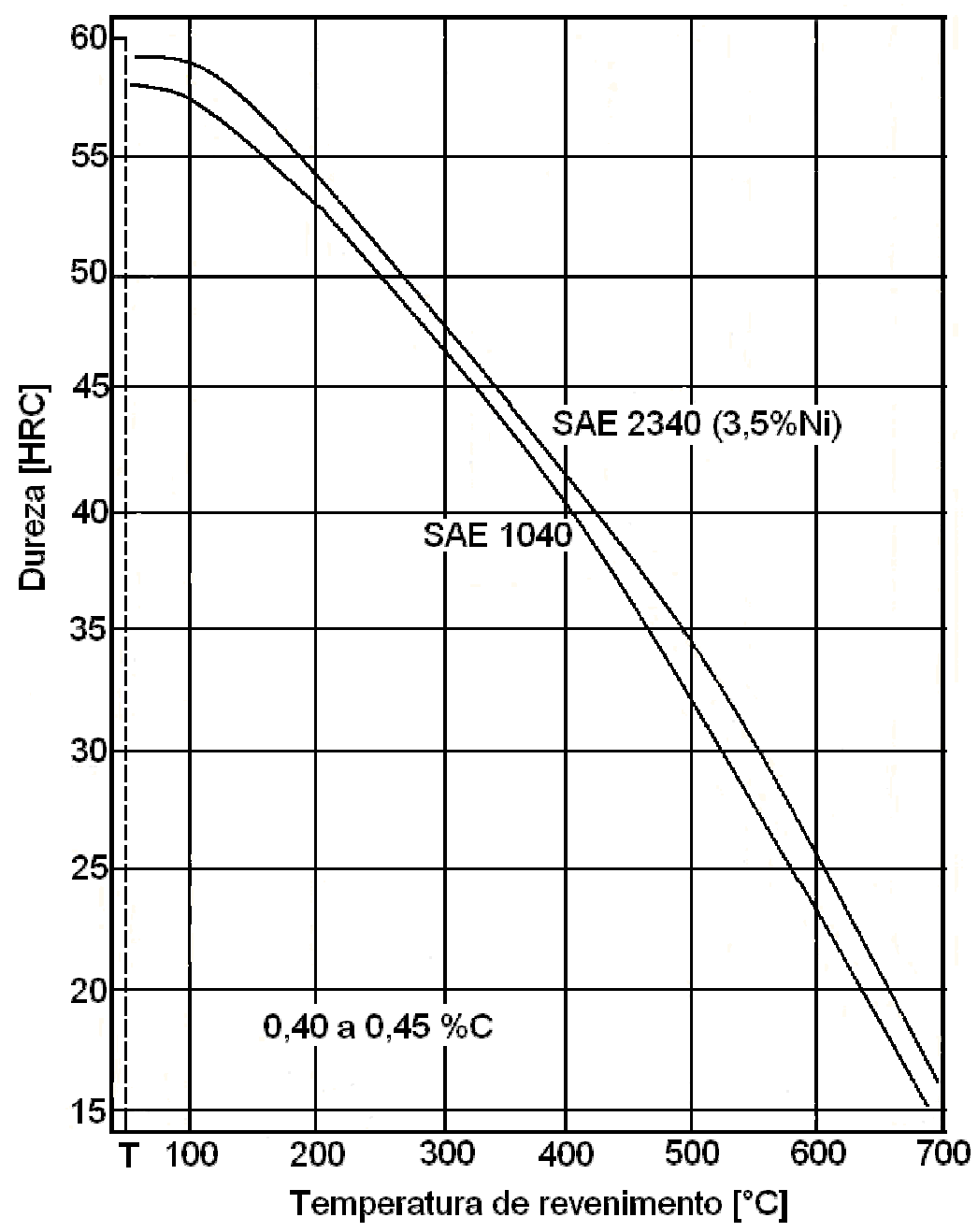

Figura 13: Comparação das curvas de revenimento dos aços SAE 1040 e SAE 2340 (BAIN e PAXTON, 1961). 


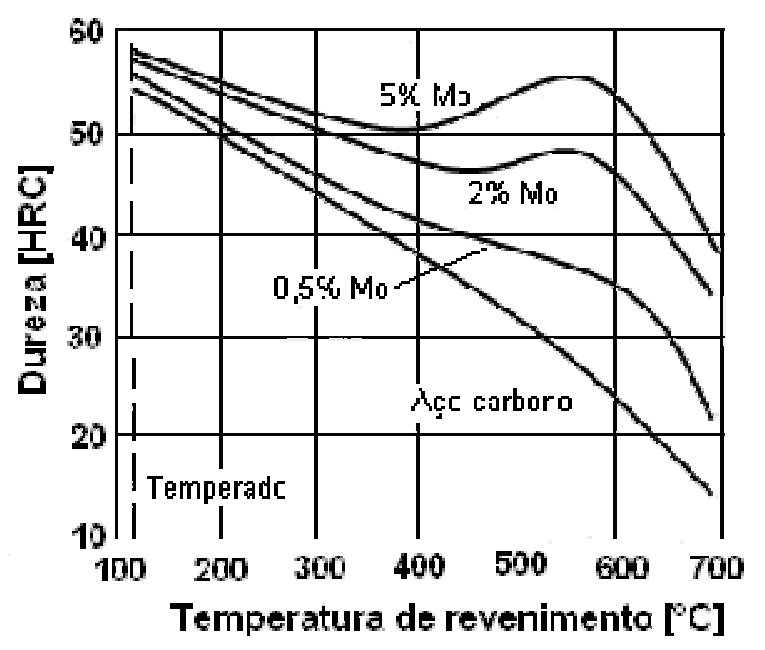

Figura 14: Influência quantidade de molibdênio no endurecimento secundário para aços temperados com 0,35\% C (BAIN e PAXTON, 1961).

A tenacidade é a medida da quantidade de energia que é absorvida por um material à medida que ele se fratura. Pode ser indicada pela área total sob a curva tensão-deformação para o material em tração ou ser medida pelo teste de impacto, o qual mede o quanto de energia um material pode absorver até a fratura. A Figura 15 traz o comportamento comum da energia de impacto e da dureza nos metais. A temperatura onde a energia tem um valor mínimo é denominada temperatura de transição. Neste ponto mínimo também é possível observar a ocorrência de um fenômeno denominado fragilidade do revenimento que será abordado na seção 2.4.6.

A Figura 16 mostra a energia de impacto em função da temperatura de teste, para um aço $0,45 \% \mathrm{C}$ revenido em diferentes temperaturas. A partir destes dados, foi obtida a temperatura de transição para cada tratamento, e os resultados estão na Figura 17, onde fica evidente que a temperatura de transição diminui com a temperatura de revenimento. Segundo Brooks (1996) o comportamento dos aços ligados é similar ao dos aços carbono, sendo que os aços ligados apresentam melhor tenacidade, como mostra a Figura 18, que traz a energia de impacto para os aços SAE 1013 e SAE 4315 em três condições: temperados, revenidos por $7 \mathrm{~h}$ a $204^{\circ} \mathrm{C}$ e revenidos com dureza igual a $290 \mathrm{HV}$. 


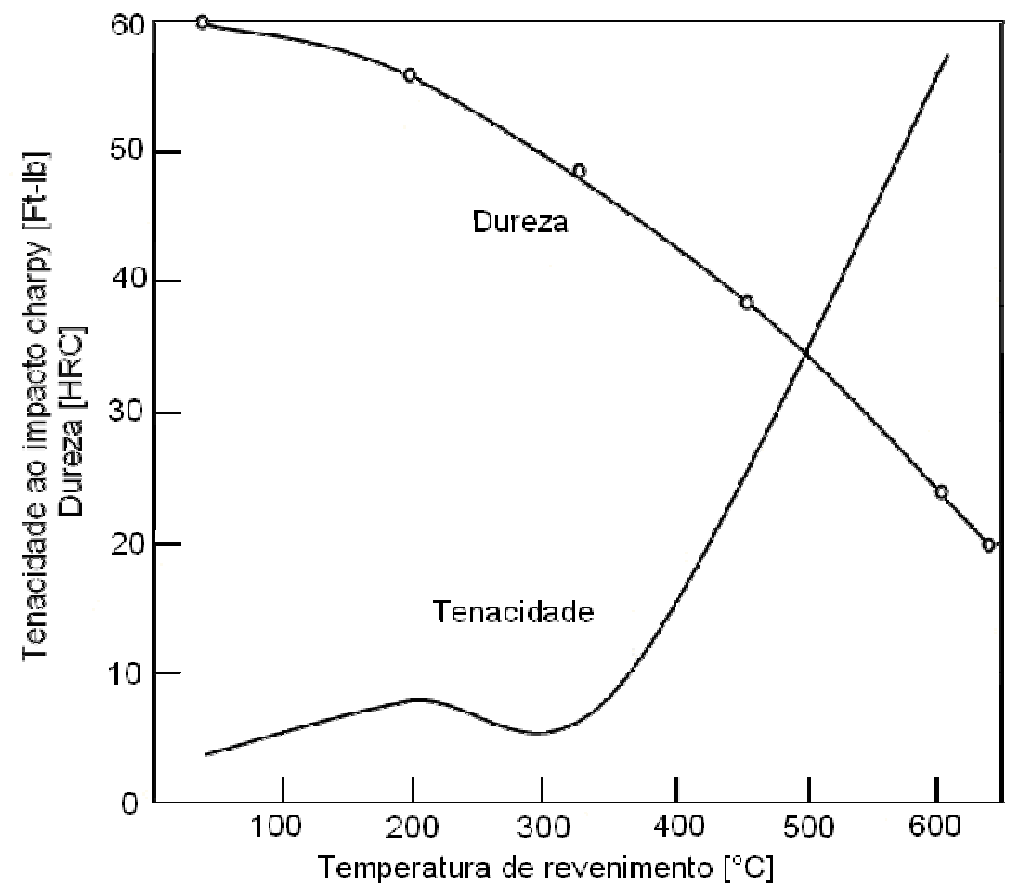

Figura 15: Energia de impacto e dureza em função da temperatura de revenimento de um aço 0,45\% C (Adaptado de BROOKS, 1996).

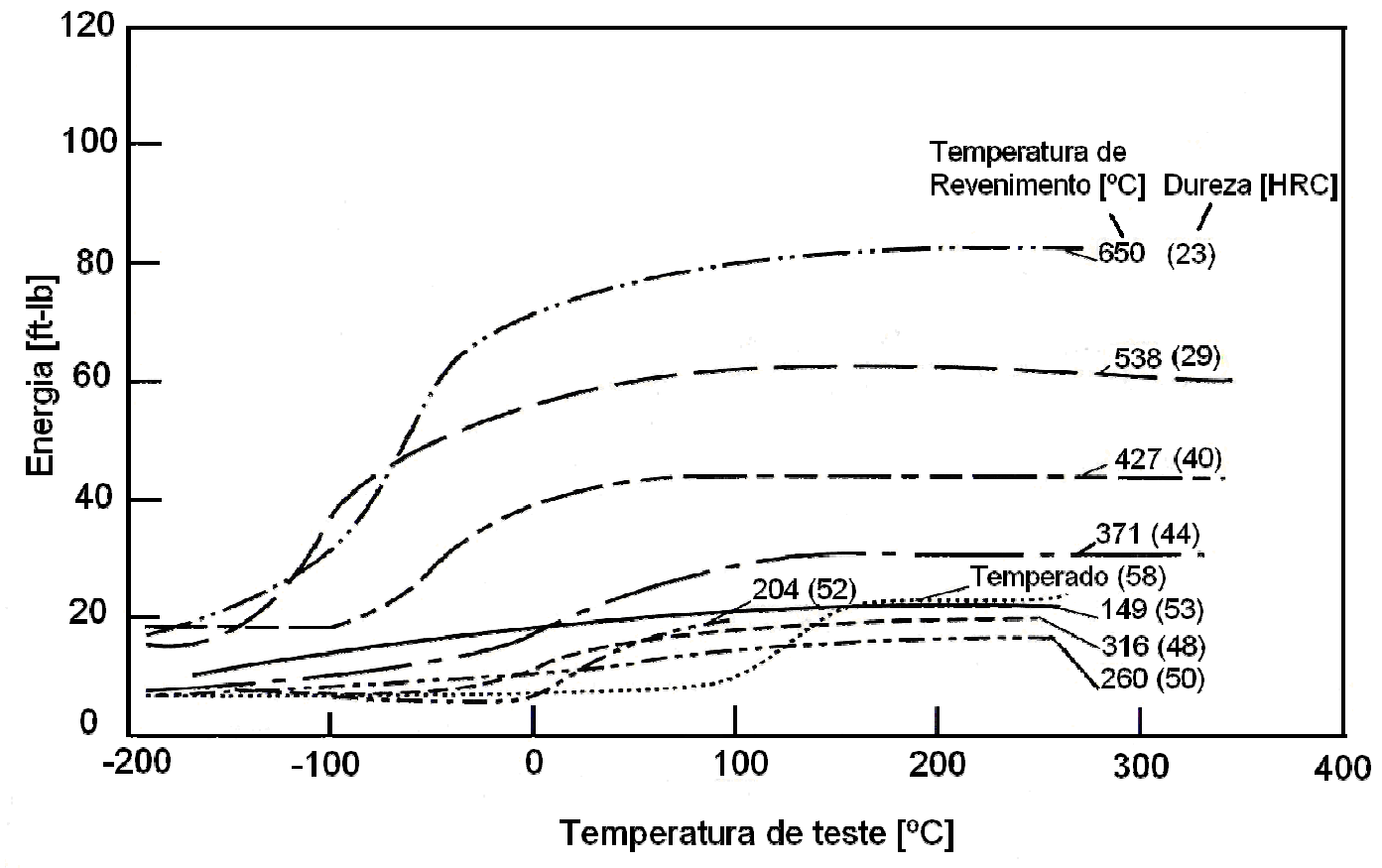

Figura 16: Curvas de revenimento para um aço carbono revenido em diferentes temperaturas (BROOKS, 1996). 


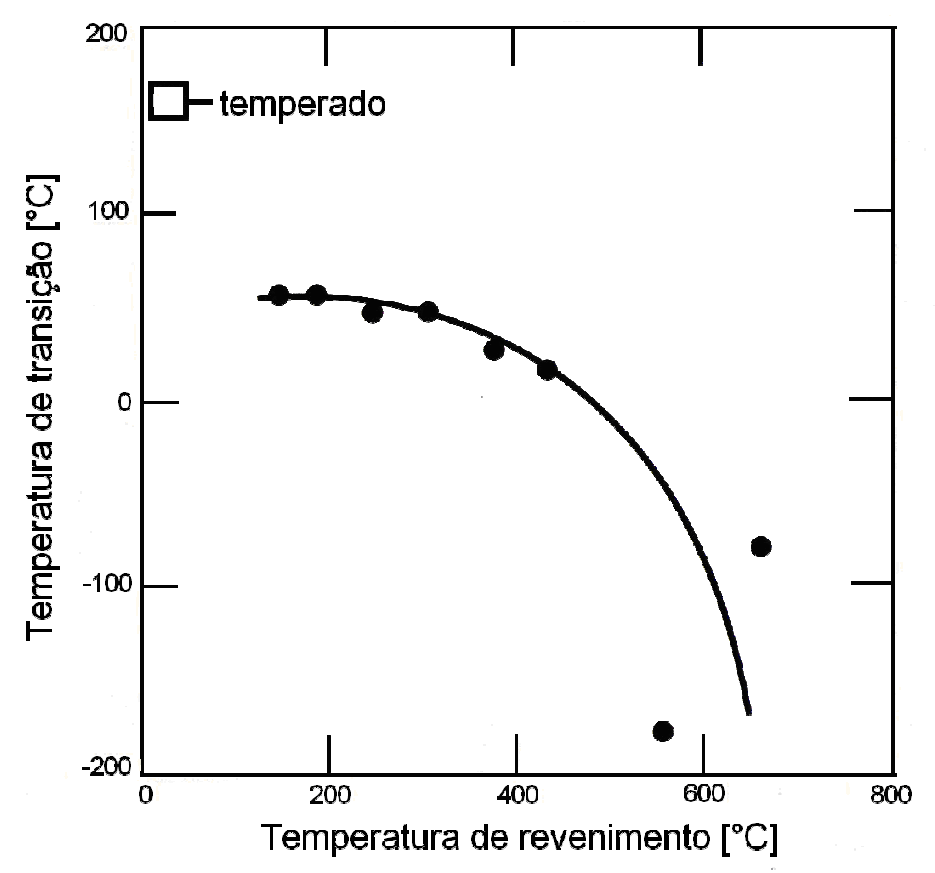

Figura 17: Temperatura de transição em função da temperatura de revenimento, derivado da Figura 16 (BROOKS, 1996).
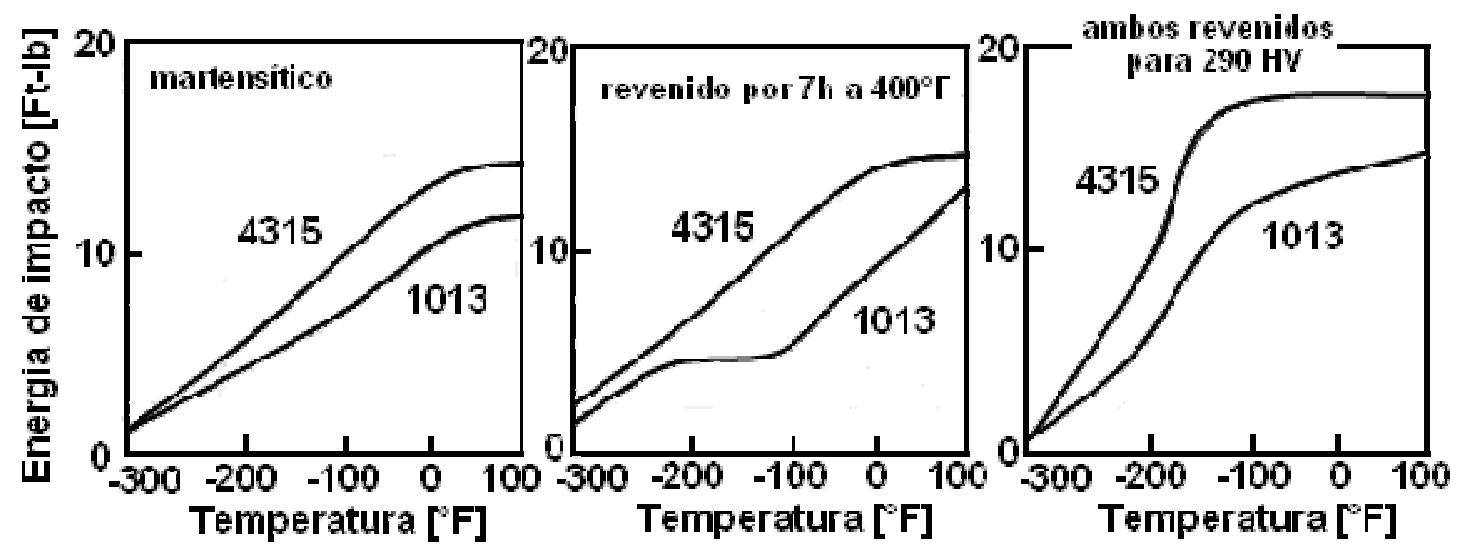

Figura 18: Energia de impacto em função da temperatura de teste para os aços SAE 1013 e SAE 4315 (BROOKS, 1996).

A Figura 19 ilustra a variação nas propriedades mecânicas para um aço carbono e para um aço ligado em função da temperatura de revenimento. 0 alongamento e a redução de área aumentam, enquanto o limite de escoamento (LE) e o limite de resistência à tração (LRT) diminuem com o incremento da temperatura de revenimento. Em geral as propriedades mecânicas dos aços ligados quando comparados a dos aços carbono refletem o mesmo comportamento de seus dados 
de dureza, apresentando valores maiores para os LE e LRT e valores mais baixos para o alongamento (ductilidade). As propriedades mecânicas para o aço SAE 5160 revenido em diferentes condições estão listadas na Tabela 1. Brooks (1996) ressalta a dificuldade de se medir as propriedades mecânicas trativas da martensita, pois o material é tão frágil que muitas vezes se obtém resultados inconsistentes, como por exemplo, o LE de um aço revenido em uma temperatura baixa ser inferior àquele medido para o mesmo aço revenido em uma temperatura mais alta. Este fato pode ser atribuído à provável presença de microtrincas da martensita.
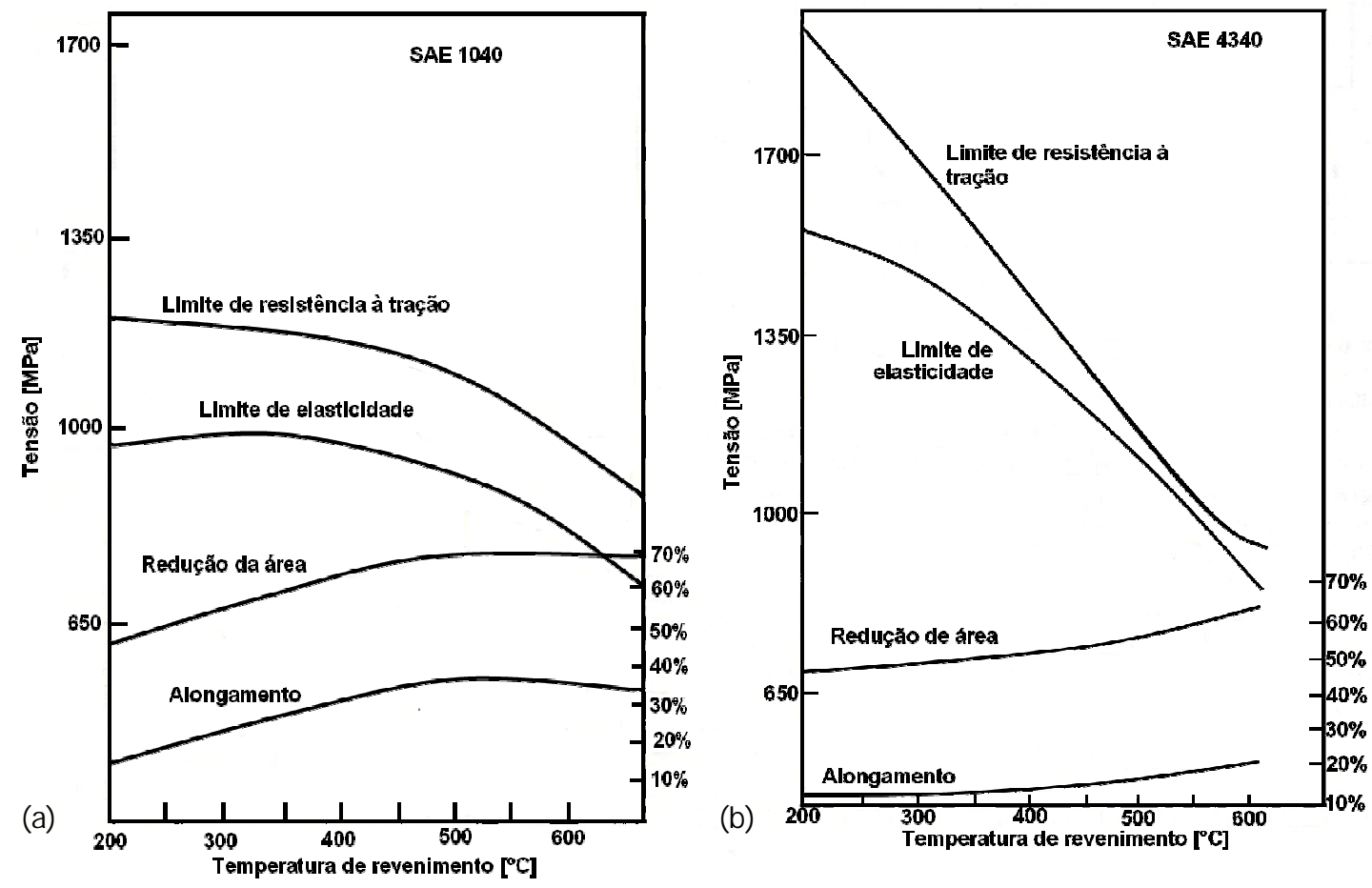

Figura 19: Variações nas propriedades mecânicas em relação à temperatura de revenimento para os açoS (a) SAE 1040 e (b) SAE 4340 (Adaptado de BETHLEHEM STEEL CORPORATION, 1972).

Tabela 1: Propriedades mecânicas para o aço SAE 5160, temperado de 830ㄷ C

\begin{tabular}{cccccc}
\hline $\begin{array}{c}\text { Temperatura de } \\
\text { revenimento [ㅇ] }\end{array}$ & $\begin{array}{c}\text { LRT } \\
{[\mathrm{MPa}]}\end{array}$ & $\begin{array}{c}\mathrm{LE} \\
{[\mathrm{MPa}]}\end{array}$ & $\begin{array}{c}\text { Alongamento } \\
{[\%]}\end{array}$ & $\begin{array}{c}\text { Redução da } \\
\text { área [\%] }\end{array}$ & $\begin{array}{c}\text { Dureza } \\
{[\mathrm{HB}]}\end{array}$ \\
\hline 540 & 1170 & 1070 & 14,2 & 45,1 & 341 \\
595 & 1050 & 924 & 16,6 & 50,6 & 302 \\
650 & 917 & 793 & 19,8 & 55,5 & 269 \\
\hline
\end{tabular}

(HARVEY, 1980). 
Krauss (1990) observa que o LE e o LRT apresentam valores bem distantes quando revenidos em temperaturas mais baixas e, tendem a se aproximar após revenimento em temperaturas mais altas (Figura 19). Trata-se de uma característica dos aços carbono e de baixa liga revenidos e está relacionado às diferenças no comportamento do encruamento desenvolvido durante o revenimento. A Figura 20 traz curvas tensão-deformação que ilustra as variações no encruamento desenvolvido como resultado do revenimento da martensita tipo ripas em uma liga Fe-0,2C. A taxa de encruamento na amostra temperada é bastante alta, como demonstrado pelo aumento crescente tanto da tensão quanto da deformação, enquanto a curva tensão-deformação para a amostra revenida é quase plana, indicando uma taxa de encruamento muito baixa. Esta diferença no comportamento de encruamento é atribuída à interação das discordâncias com as partículas de cementita relativamente grosseiras que se formam durante o revenimento. Nas amostras temperadas, as discordâncias se emaranham e formam uma subestrutura compacta de células finas com deformação crescente. Nas amostras revenidas a presença das partículas grosseiras de cementita garante que tais discordâncias permaneçam uniformemente distribuídas o que impede o desenvolvimento de uma estrutura de célula com uma discordância bem definida.

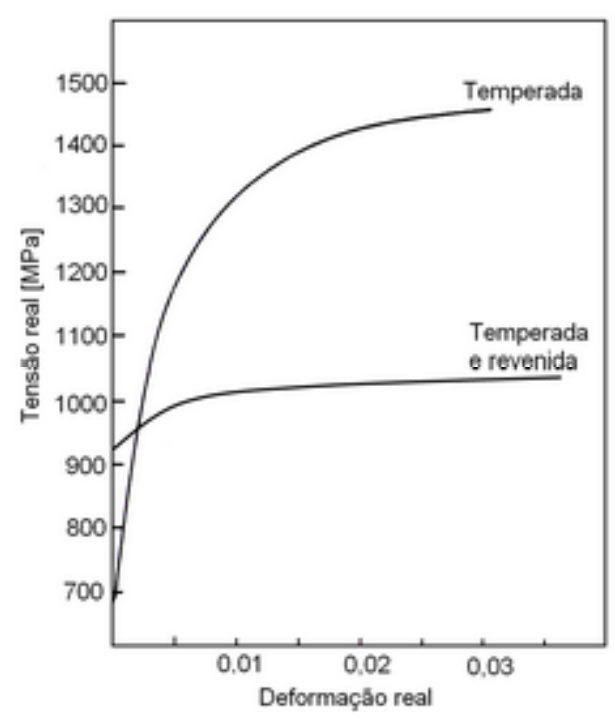

Figura 20: Curvas tensão-deformação obtidas para a martensita tipo ripas de um aço carbono Fe-0,2C temperado e temperado e revenido (KRAUSS, 1990). 


\subsubsection{Mudanças estruturais}

\subsubsection{Estágios de revenimento nos aços carbono}

Sabe-se que a estrutura martensítica formada pela têmpera é altamente instável. Krauss (1990) explica que tal instabilidade se deve à supersaturação dos átomos de carbono no reticulado cristalino tcc da martensita, à energia de deformação associada às distorções eminentes ou estruturas de macla da martensita, à energia interfacial associada à alta densidade nos contornos das ripas ou placas, e à austenita retida que está presente até mesmo nos aços de baixo carbono. Todos os motivos atribuídos à instabilidade da martensita servirão de força motriz para uma reação durante o revenimento. Por exemplo, a supersaturação dos átomos de carbono proporciona a força motriz para a formação dos carbonetos; a alta energia de deformação para a recuperação; a alta energia interfacial para o crescimento de grão ou coalescimento da matriz ferrítica e a instabilidade da austenita para a formação de ferrita e de cementita.

A resposta ao revenimento também depende da estrutura inicial do componente, a qual é fortemente influenciada pelas temperaturas $M_{i}$ e $M_{f}$. Aços que apresentam uma temperatura $M_{i}$ elevada têm a tendência de sofrer um fenômeno denominado auto-revenimento, que consiste no revenimento durante a têmpera, ou seja, há formação de carbonetos dispersos durante o resfriamento. Na Tabela 2, estão resumidos os quatro principais estágios de revenimento para os aços carbono.

Tabela 2: Estágios de revenimento dos aços carbono

\begin{tabular}{|c|c|c|}
\hline Estágio & Descrição & $\begin{array}{l}\text { Temperatura } \\
{[\stackrel{\circ}{C}]}\end{array}$ \\
\hline 1 & $\begin{array}{l}\text { Formação do carboneto de transição } \varepsilon \text { e a diminuição da } \\
\text { quantidade de carbono na matriz martensítica em até } \\
0,25 \% \text { C. Perda parcial da tetragonalidade da martensita. }\end{array}$ & $100-250$ \\
\hline II & Decomposição da austenita retida em ferrita e cementita. & $200-300$ \\
\hline III & $\begin{array}{l}\text { Substituição do carboneto de transição e da martensita de } \\
\text { baixo carbono por cementita e ferrita. }\end{array}$ & $250-350$ \\
\hline IV & $\begin{array}{l}\text { Coalescimento e esferoidização da cementita e } \\
\text { recristalização da ferrita. }\end{array}$ & $\begin{array}{l}\text { Acima de } \\
350^{\circ} \mathrm{C}\end{array}$ \\
\hline
\end{tabular}

(KRAUSS, 1990 e HONEYCOMBE e BHADESHIA, 1995). 
Segundo Honeycombe e Bhadeshia (1995) a martensita formada nos aços de médio e alto carbono $(0,3$ a 1,5 \%C) não é estável na temperatura ambiente, pois os átomos de carbono intersticiais se difundem no reticulado tetragonal da martensita nesta temperatura. Esta instabilidade aumenta entre a temperatura ambiente e $250^{\circ} \mathrm{C}$, quando o carboneto $\varepsilon$ se precipita da martensita. De fato, nos aços de alto carbono, se observa um aumento na dureza quando revenidos no intervalo entre 50 e $100^{\circ} \mathrm{C}$, o que é atribuído ao endurecimento por precipitação da martensita pelo carboneto $\varepsilon$ (Figuras 10 e 11, páginas 34 e 35). Ao final do primeiro estágio a martensita preserva sua estrutura tetragonal. No entanto Krauss (1990) mostra que há a formação de outras estruturas durante o primeiro estágio. Trata-se de uma estrutura modulada associada ao agrupamento dos átomos de carbono no plano (102) da martensita e de um carboneto com estrutura ortorrômbica e composição $\mathrm{Fe}_{4} \mathrm{C}$. Esta estrutura se forma entre 0 e $90^{\circ} \mathrm{C}$, enquanto a estrutura anterior se forma entre 60 e $80^{\circ} \mathrm{C}$. Assim, o revenimento envolve muito mais que quatro estágios de revenimento, como Krauss (1984) resumiu na Tabela 3, porém neste trabalho serão discutidos apenas os quatro primeiros estágios de revenimento.

Tabela 3: Sequência dos eventos no revenimento dos aços

\begin{tabular}{|c|c|}
\hline $\begin{array}{c}\text { Temperatura } \\
{\left[{ }^{\circ} \mathrm{C}\right]}\end{array}$ & Reação \\
\hline-40 a 100 & $\begin{array}{l}\text { Agrupamento de } 2 \text { a } 4 \text { átomos de carbono nos sítios octaédricos da } \\
\text { martensita e segregação dos átomos de carbono para os contornos } \\
\text { das discordâncias. }\end{array}$ \\
\hline 20 a 100 & $\begin{array}{l}\text { Arranjos modulados dos átomos de carbono no plano (102) da } \\
\text { martensita. }\end{array}$ \\
\hline 60 a 80 & Carboneto $\mathrm{Fe}_{4} \mathrm{C}$. \\
\hline 100 a 200 & Precipitação do carboneto $\eta$, antes identificado como carboneto $\varepsilon$. \\
\hline 200 a 350 & Transformação da austenita retida em ferrita e cementita. \\
\hline 250 a 700 & $\begin{array}{l}\text { Formação da ferrita e da cementita; eventual desenvolvimento de } \\
\text { carbonetos coalescidos na matriz ferrítica de grãos equiaxiais. Este } \\
\text { estágio aparentemente se inicia pela formação dos carbonetos } \chi \text { nos } \\
\text { aços de alto carbono. }\end{array}$ \\
\hline 500 a 700 & Formação dos carbonetos de liga nos aços contendo $\mathrm{Cr}$, Mo, V e W. \\
\hline 350 a 550 & $\begin{array}{l}\text { Segregação e cosegregaçao das impurezas e dos elementos de liga } \\
\text { substitutivos, o que provoca a fragilização do revenimento. }\end{array}$ \\
\hline
\end{tabular}
(KRAUSS, 1984). 
A princípio os carbonetos de transição $\varepsilon$ foram identificados como tendo uma estrutura hexagonal. Porém Krauss (1990) relata que mais tarde se percebeu que 0 carboneto de transição possui na verdade uma estrutura ortorrômbica isomorfa com carbonetos de transição metálicos do tipo $\mathrm{M}_{2} \mathrm{C}$ (onde $\mathrm{M}$ representa a combinação dos átomos de $\mathrm{Fe}$ e $\mathrm{Cr}$ ). Os carbonetos de transição com esta estrutura foram designados como carboneto $\eta$. As estruturas dos carbonetos $\varepsilon$ e $\eta$ são muito similares e se diferenciam principalmente pelos pontos de difração de elétrons que vêm de um arranjo regular de átomos de carbono do carboneto $\eta$. Tanto 0 carboneto $\varepsilon$, $\mathrm{Fe}_{2,4} \mathrm{C}$, quanto 0 carboneto $\eta$, $\mathrm{Fe}_{2} \mathrm{C}$, têm quantidade de carbono substancialmente maior que a cementita, $\mathrm{Fe}_{3} \mathrm{C}$, que se forma em temperaturas mais altas. Estudos cinéticos mostram que o primeiro estágio de revenimento depende da difusão do carbono por meio da martensita com uma energia de ativação de 80 $\mathrm{kJ} / \mathrm{mol}$.

Durante o segundo estágio acontece a transformação da austenita retida no intervalo entre 200 e $300^{\circ} \mathrm{C}$ após a estabilização do carboneto de transição. Análises da cinética de transformação da austenita revelaram uma energia de ativação de 115 $\mathrm{kJ} / \mathrm{mol}$ para o segundo estágio de revenimento (KRAUSS, 1990). Honeycombe e Bhadeshia (1995) destacam ainda o aumento volumétrico nesta fase e afirmam que há indícios que a austenita retida se transforma em bainita inferior, que consiste em ferrita e carboneto $\varepsilon$. A Figura 21 mostra que a quantidade de austenita retida para os aços 4130 e 4340 fica em torno de $2 \%$ e $4 \%$ respectivamente, quando revenidos por 1 hora, a transformação começa aos $200^{\circ} \mathrm{C}$ e em torno dos $300^{\circ} \mathrm{C}$ a cementita já começa a fazer parte da microestrutura do aço.

O terceiro estágio de revenimento consiste na formação da ferrita e da cementita como preconiza o diagrama Fe-C. No entanto, Krauss (1990) relata que há alguma evidência, especialmente nos aços de alto carbono, que a formação do carboneto $\chi$ ou Hägg preceda a da cementita. 0 carboneto $\chi$ tem uma estrutura monoclínica, e composição $\mathrm{Fe}_{5} \mathrm{C}_{2}$. No entanto, apesar das diferenças entre a cementita e 0 carboneto $\chi$, suas estruturas relativamente complexas são similares e difíceis de separar por técnicas de raio-x ou difração por elétrons. Devido à dificuldade experimental em diferenciar o carboneto $\chi$ da cementita, a temperatura e 
composições dos aços para os quais os carbonetos $\chi$ são formados ainda não foram completamente definidos.

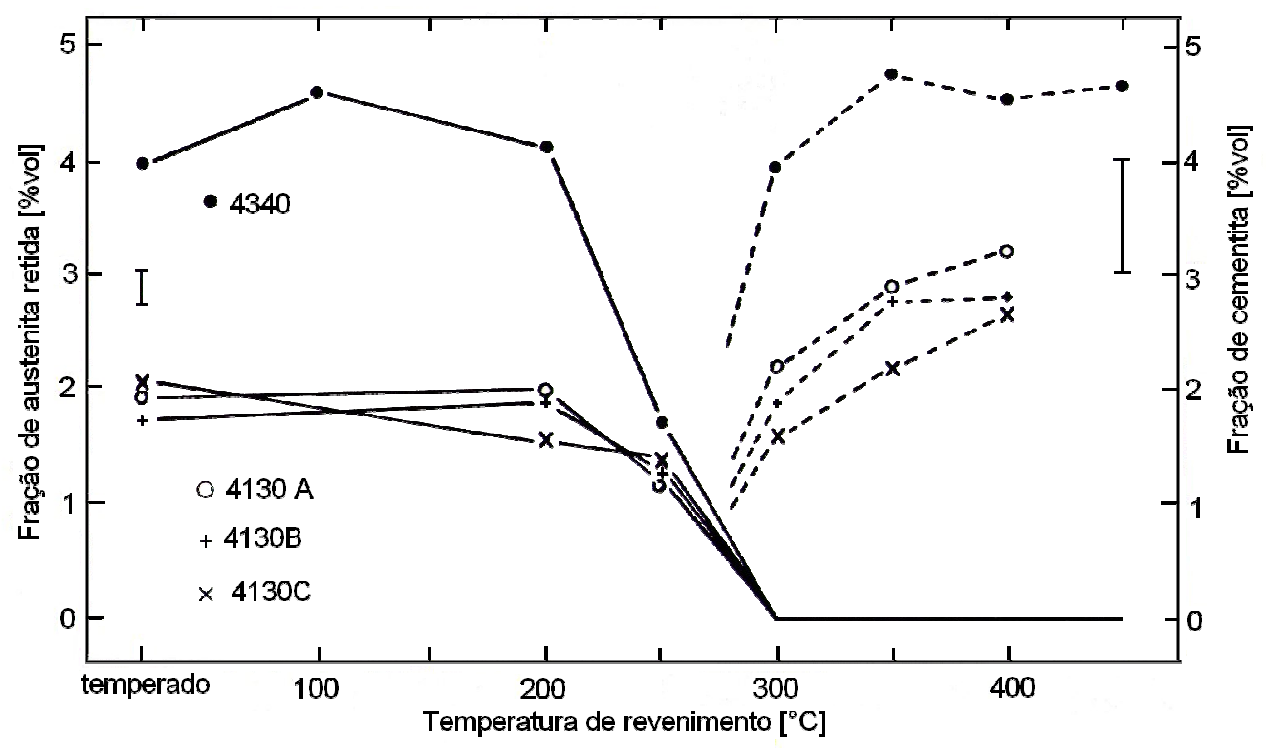

Figura 21: Quantidade de austenita retida e de cementita em função da temperatura de revenimento para os aços 4130 e 4340 (KRAUSS, 1990).

O sítio mais provável para a nucleação da cementita é na interface do carboneto de transição com a matriz. À medida que as partículas de cementita crescem as partículas do carboneto $\varepsilon$ vão desaparecendo. Os contornos das maclas presentes na martensita de alto carbono também são sítios para a nucleação e crescimento da cementita, assim como a região de contorno de grão, seja entre as ripas da martensita ou contorno de grão original da austenita (HONEYCOMBE e BHADESHIA, 1995).

A Tabela 4 mostra a estrutura e a composição química dos carbonetos formados durante o revenimento.

Tabela 4: Carbonetos formados durante o revenimento

\begin{tabular}{cccc}
\hline Designação & Nome & Estrutura & Composição \\
\hline$\eta$ & & ortorrômbica & $\mathrm{Fe}_{2} \mathrm{C}$ \\
$\chi$ & carboneto Hägg & monoclínica & $\mathrm{Fe}_{2,2} \mathrm{C}$ \\
$\varepsilon$ & & hexagonal & $\mathrm{Fe}_{2,4} \mathrm{C}$ \\
$\theta$ & cementita & ortorrômbica & $\mathrm{Fe}_{3} \mathrm{C}$ \\
\hline
\end{tabular}

(BROOKS, 1996). 
Durante o quarto estágio de revenimento a cementita passa pelos processos de coalescimento e de esferoidização. O coalescimento se inicia em torno de $350^{\circ} \mathrm{C}$, enquanto a esferoidização vai aumentando gradativamente até $700^{\circ} \mathrm{C}$. Ao final deste intervalo os contornos da martensita tipo ripas são substituídos por contornos de grãos ferríticos mais equiaxiais, através de um processo que é definido como recristalização. O resultado final é um arranjo equiaxial de grãos de ferrita com partículas esféricas de cementita, principalmente nos contornos de grão.

A esferoidização da cementita é favorecida pelo decréscimo da energia superficial e também acontece preferencialmente nos contornos entre ripas e nos antigos contornos da austenita, embora algumas partículas permaneçam na matriz. Os contornos são priorizados devido à maior facilidade de difusão nestas regiões.

O contorno original da martensita se mantém estável até $600^{\circ} \mathrm{C}$. No entanto entre $350-600^{\circ} \mathrm{C}$ há uma redistribuição das discordâncias entre as ripas. Isto induz a uma redução marcante na densidade da discordância e à formação de grãos ferríticos na forma de ripas similarmente orientados como as ripas da martensita original. Este processo, que é essencialmente um tipo de recuperação, é substituído entre 600 e $700^{\circ} \mathrm{C}$ pela recristalização que resulta na formação de grãos de ferrita equiaxiais com partículas esféricas de cementita nos contornos e entre os grãos. Este processo é mais comum nos aços de baixo carbono. Nos aços de alto carbono 0 aumento na densidade das partículas de cementita é muito mais efetivo nos contornos da ferrita, assim a recristalização é muito mais lenta. 0 processo final é o coalescimento contínuo das partículas de cementita e o crescimento gradual do grão de ferrita (HONEYCOMBE e BHADESHIA, 1995).

\subsubsection{Nucleação e crescimento dos carbonetos de liga}

Para os aços ligados, Brooks (1996) destaca que os estágios de revenimento incluem aqueles descritos para os aços carbono, mas pode haver ainda a formação dos carbonetos de liga, além da cementita e do carboneto $\varepsilon$. Os carbonetos de liga aparecem no intervalo de temperatura entre 500 e $700^{\circ} \mathrm{C}$ após uma ou duas horas na temperatura. Geralmente ocorre em aços contendo $\mathrm{Cr}$, Mo, V ou W. Estes carbonetos são responsáveis pelo endurecimento secundário e/ou pelo atraso pronunciado do amolecimento durante o revenimento. 
Segundo Honeycombe e Bhadeshia (1995) os carbonetos de liga podem ser formados de pelo menos três maneiras: por nucleação in situ nas partículas préexistentes de cementita, por nucleação separada dentro da matriz ferrítica e nos contornos e nos sub-contornos de grãos.

A nucleação in situ nas partículas pré-existentes de cementita é um evento trivial, porém como estas partículas são convenientemente bastante espaçadas em temperaturas acima de $500^{\circ} \mathrm{C}$, a contribuição deste tipo de nucleação de carboneto de liga para a resistência é muito limitada.

A nucleação dos carbonetos nos diversos tipos de contorno é esperada porque estes sítios são energeticamente favoráveis o que também fornece condição para uma difusão relativamente rápida do soluto. Consequentemente o processo de envelhecimento é comumente mais avançado nestas regiões e o precipitado mais maciço. Geralmente o primeiro carboneto a se formar não é o carboneto de equilíbrio final e, em alguns aços, pelo menos três carbonetos de liga podem ser formados sucessivamente. Nestas circunstâncias, 0 carboneto de liga de equilíbrio frequentemente inicia sua nucleação nos contornos de grão, cresce rapidamente e substitui o carboneto de não-equilíbrio entre os grãos.

\subsubsection{Variações dimensionais}

Os aços revenidos tendem a se contrair devido às transformações que sofrem. Durante a têmpera a formação da martensita está associada a um acréscimo de volume. Durante o revenimento a martensita se decompõe em uma mistura de ferrita e cementita resultando em uma diminuição de volume à medida que a temperatura de revenimento aumenta. No entanto, é preciso fazer uma ressalva, a austenita retida no componente temperado provoca um aumento de volume no segundo estágio de revenimento. A Figura 22 mostra a variação sofrida no comprimento, na largura, e na espessura pelo aço ferramenta 01, austenitizado em $830^{\circ} \mathrm{C}$, temperado em óleo e revenido por 1 hora. 

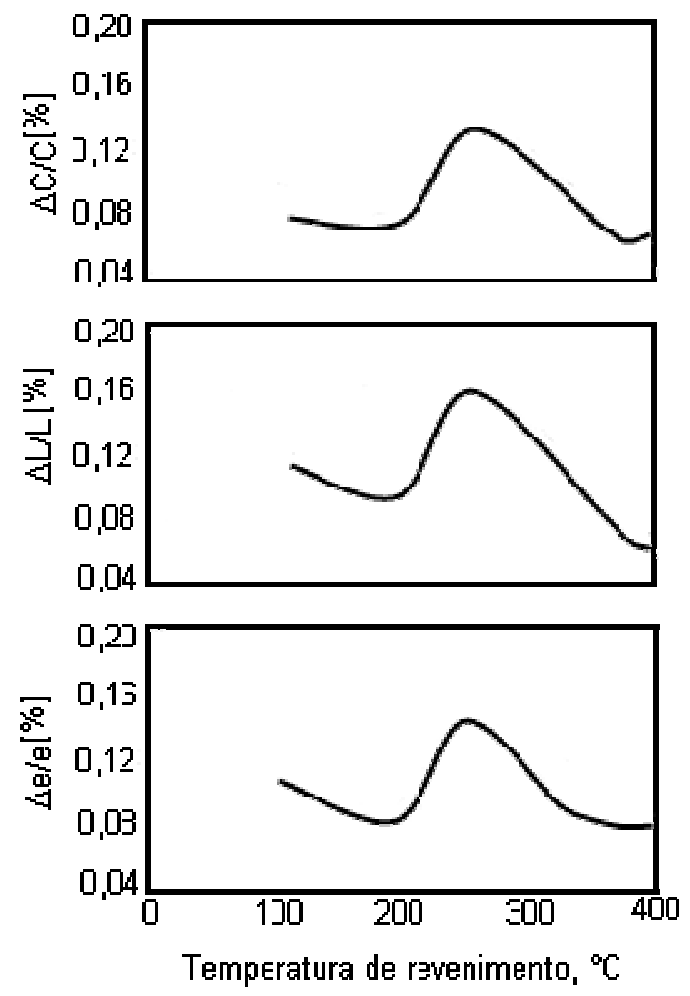

Figura 22: Variações dimensionais em decorrência do revenimento para o aço ferramenta 01 (AMERICAN SOCIETY FOR METALS, 1998).

\subsubsection{Efeito da quantidade de carbono}

Sabe-se que a dureza como temperada é altamente influenciada pela quantidade de carbono. A temperatura $M_{i}$ diminui com 0 aumento do carbono $\mathrm{e}$ consequentemente a probabilidade de acontecer o auto-revenimento é menor. A Figura 23 mostra o amolecimento como função da temperatura de revenimento e do teor de carbono. Este amolecimento se deve basicamente ao rápido crescimento da cementita com o aumento da temperatura de revenimento, um processo que depende da difusão do carbono e do ferro.

\subsubsection{Efeito dos elementos de liga}

Segundo Krauss (1990) alguns elementos de liga além de melhorar a temperabilidade têm a capacidade de diminuir a taxa de amolecimento durante 0 revenimento. Os elementos mais efetivos neste sentido são os potenciais formadores de carbonetos tais como: cromo, molibdênio e vanádio. Ressalta-se ainda que se 
estiverem presentes em quantidade suficiente, estes elementos não só atrasam 0 amolecimento, mas também promovem um acréscimo na dureza nas temperaturas mais altas, devido à formação dos carbonetos de liga conforme explanado na seção 2.4.2.2. Este aumento de dureza é frequentemente reportado como endurecimento secundário.

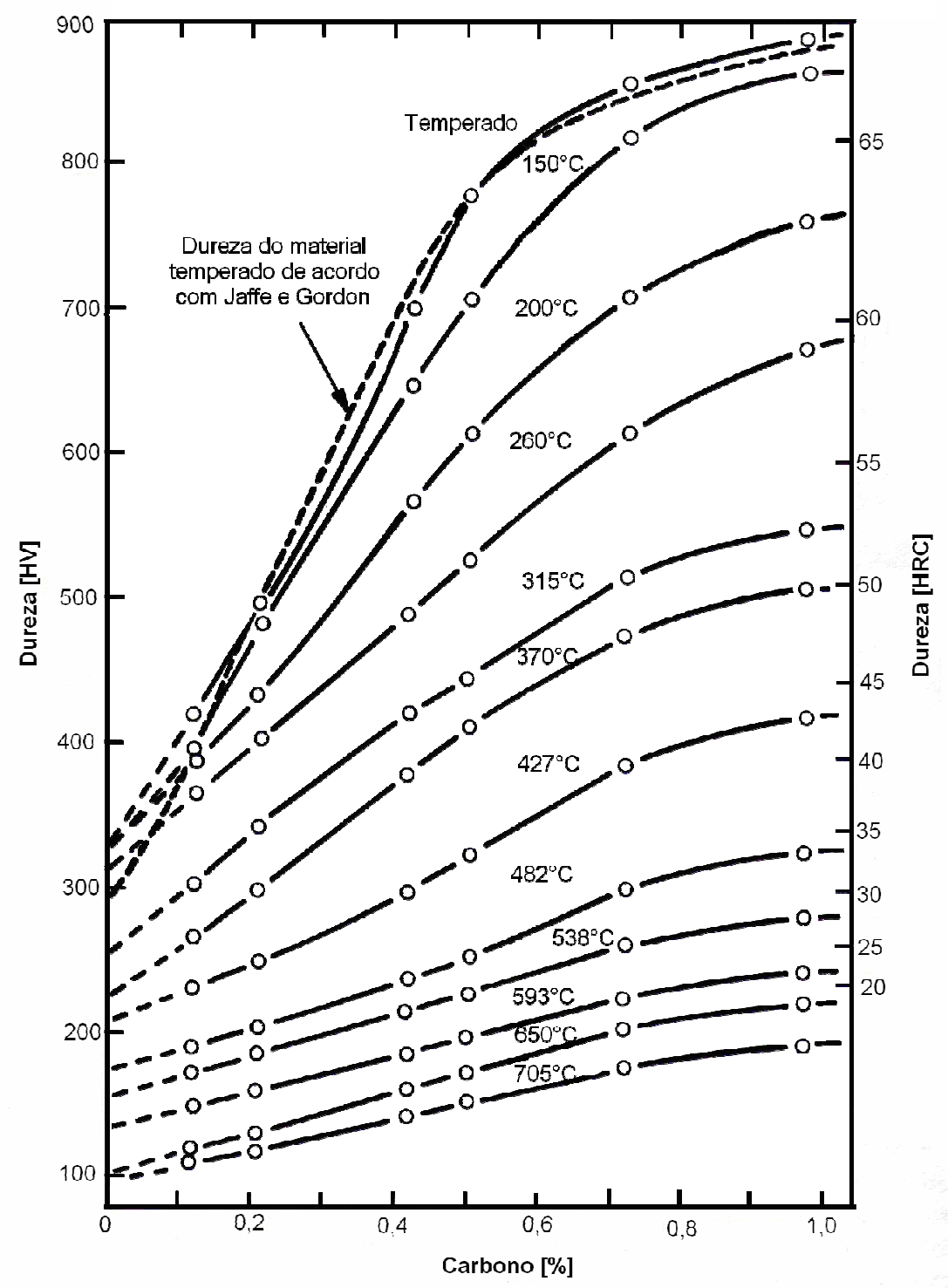

Figura 23: Dureza da martensita revenida em ligas de aço Fe-C. Estas curvas mostram a relação da quantidade de carbono e dureza após 0 revenimento em várias temperaturas por uma hora (GRANGE; HIBRAL e PORTER, 1977). 
Honeycombe e Bhadeshia (1995) relatam que o coalescimento dos carbonetos nos aços é um fenômeno que influencia diretamente as propriedades mecânicas. A taxa de coalescimento depende do coeficiente de difusão do soluto e, sob as mesmas condições, a dada temperatura, a cementita coalesce mais rapidamente que os carbonetos de liga já formados. Isto acontece nos aços que a cementita e os carbonetos de liga coexistem, onde a dispersão da cementita é sempre mais grosseira. Esta habilidade de formar uma refinada dispersão de carbonetos de liga no intervalo entre 500 e $600^{\circ} \mathrm{C}$, que permanece refinada até depois de um longo período de revenimento, é o que permite o desenvolvimento de altos níveis de resistência. A melhora da resistência pode ser superior àquela obtida pela martensita temperada. Este fenômeno é denominado endurecimento secundário e acontece nas ligas de alta concentração de molibdênio, vanádio, tungstênio, titânio e cromo.

Honeycombe e Bhadeshia (1995) definem o endurecimento secundário como um tipo de endurecimento por precipitação, no qual uma dispersão de cementita grosseira é substituída por uma dispersão mais refinada de carbonetos de liga. A Figura 14 (pagina 35) mostrou o efeito do molibdênio no endurecimento secundário.

Brooks (1996) resume o efeito de alguns elementos de liga no revenimento na Tabela 5.

\subsubsection{Fenômenos de fragilização}

É denominada fragilidade da martensita revenida (FMR) o fenômeno que acontece nos aços revenidos entre 250 e $370^{\circ} C$. É também denominada de fragilidade azul porque ocorre em temperaturas que provocam uma oxidação azulada no aço. Segundo Vatavuk e Canale (2008) esta fragilização acontece devido à precipitação da cementita nos contornos de grão e entre as agulhas de martensita, podendo estar associada ou não a segregação dos átomos de impureza. Por esta razão este intervalo de temperatura deve ser evitado na prática, embora ele possa aumentar o limite de resistência à tração. Tanto a fratura intergranular quanto a fratura transgranular são observadas na FMR (AMERICAN SOCIETY FOR METALS, 1998). 
Tabela 5: Efeitos dos elementos de liga no revenimento dos aços

\begin{tabular}{|c|c|}
\hline Elemento & Efeito \\
\hline $\mathrm{Mn}$ & $\begin{array}{l}\text { Aumenta a dureza da martensita revenida atrasando o coalescimento dos } \\
\text { carbonetos, o que previne o crescimento de grão na matriz ferrítica. }\end{array}$ \\
\hline $\mathrm{Ni}$ & $\begin{array}{l}\text { Pouco influencia na dureza revenida, não é um formador de carboneto, } \\
\text { mas atua como um fraco reforço da solução sólida. }\end{array}$ \\
\hline $\mathrm{Cu}$ & $\begin{array}{l}\text { Precipita quando o aço é aquecido por volta de } 425-650^{\circ} \mathrm{C} \text { e assim pode } \\
\text { produzir um grau de endurecimento por precipitação. }\end{array}$ \\
\hline $\mathrm{Si}$ & $\begin{array}{l}\text { Aumenta a dureza da martensita revenida. Também atrasa o } \\
\text { amolecimento a } 316 \cong \mathrm{C} \text { e inibe a conversão do carboneto } \varepsilon \text { em cementita. }\end{array}$ \\
\hline Mo & $\begin{array}{l}\text { Retarda o amolecimento da martensita. Acima de } 540^{\circ} \mathrm{C} \text { se particiona na } \\
\text { fase de carboneto, criando pequenas e numerosas partículas de } \\
\text { carbonetos. Além disso, ele reduz a suscetibilidade à fragilidade do } \\
\text { revenimento. }\end{array}$ \\
\hline $\mathrm{Cr}$ & $\begin{array}{l}\text { Potente formador de carboneto atrasa o amolecimento da martensita e } 0 \\
\text { coalescimento dos carbonetos substituindo alguns átomos de } \mathrm{Fe} \mathrm{da} \mathrm{Fe}_{3} \mathrm{C} \text {. }\end{array}$ \\
\hline V & $\begin{array}{l}\text { Formador de carboneto mais potente que o } \mathrm{Cr} \text { e o Mo exibindo um efeito } \\
\text { mais acentuado em ligas equivalentes. } \mathrm{O} \text { efeito intenso do } \mathrm{V} \text { se deve a } \\
\text { formação de um carboneto de liga que substitui a } \mathrm{Fe}_{3} \mathrm{C} \text { em altas } \\
\text { temperaturas de revenimento e permanece como uma dispersão fina até } \\
\text { a temperatura } \mathrm{A}_{1}\end{array}$ \\
\hline W & $\begin{array}{l}\text { Potencial formador de carboneto que se comporta como o Mo nos aços } \\
\text { comuns. }\end{array}$ \\
\hline $\begin{array}{l}\mathrm{Ti}, \mathrm{Nb} \\
\mathrm{Zr}\end{array}$ & Potenciais formadores de carbonetos. \\
\hline B & $\begin{array}{l}\text { Não provoca nenhum efeito nas características de revenimento da } \\
\text { martensita, embora um efeito prejudicial na tenacidade possa ser } \\
\text { resultado da transformação de produtos não martensíticos. }\end{array}$ \\
\hline
\end{tabular}

(Adaptado de BROOKS, 1996).

O outro tipo de fragilidade é denominado fragilização do revenido e acontece no intervalo de temperatura entre 450 e $600^{\circ} \mathrm{C}$. Esta fragilidade está diretamente relacionada à segregação das impurezas próxima aos contornos de grão da austenita. A susceptibilidade a esta fragilidade aumenta com a presença dos elementos de liga Mn, Cr e Ni (VATAVUK e CANALE, 2008).

A combinação da segregação das impurezas tais como fósforo e enxofre nos contornos de grão da austenita durante a austenitização e a formação da cementita nos contornos antigos da austenita durante o revenimento são responsáveis pelo modo de fratura intergranular na fragilização da martensita revenida. 0 modo de fratura transgranular é causado pela formação da cementita entre as ripas paralelas 
de martensita durante o revenimento. A Figura 24 mostra como o aumento na quantidade de fósforo tende a fragilizar os aços de baixa liga.

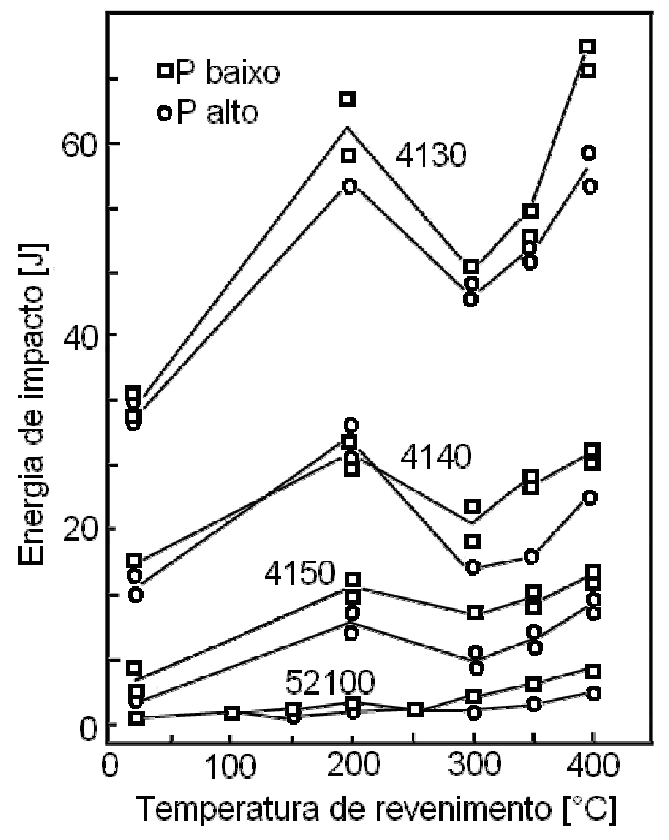

Figura 24: Energia de impacto absorvida em um corpo de prova Charpy não entalhado para aços com diferentes teores de carbono e fósforo (KRAUSS, 1990).

\subsection{PARÂMETROS DE REVENI MENTO}

O processo de revenimento é dependente tanto da temperatura quanto do tempo na temperatura de processo. A escolha inapropriada destes parâmetros pode afetar potencialmente a fragilização do revenido, o alívio das tensões, o trincamento atribuível à corrosão sob tensão, a dureza, a tenacidade e a transformação da austenita retida.

Um parâmetro de revenimento $(P)$, combinando tempo e temperatura, foi utilizado por Hollomon e Jaffe (1945) a fim de interpretar os resultados obtidos do revenimento na dureza revenida dos aços temperados. Para isso adotaram que a hipótese mais óbvia da relação entre tempo e temperatura de revenimento é aquela que assume a forma da equação de difusão. Eles estudaram seis aços carbono cuja 
quantidade de carbono variou entre 0,31 e 1,51\% e assumiram que a dureza era uma função do parâmetro:

$$
t e^{-Q / R T}
$$

onde $t$ o tempo de revenimento em segundos, $T$ a temperatura (absoluta) de revenimento, $R$ a constante ideal dos gases e $Q$ não é uma constante, mas uma variável, uma função da dureza $(H)$, como expressa a equação (3):

$$
Q=f_{1}(H)
$$

Considerando a teoria da velocidade de reação:

$$
t_{0}=t e^{-Q / R T}
$$

Reescrevendo a equação (4) na forma logarítmica, tem-se:

$$
\log t_{0}=\log t-\left(\frac{Q}{2,3 R T}\right) \log e
$$

Rearranjando a equação (5) e igualando a equação (2):

$$
T\left(\log t-\log t_{0}\right)=P
$$

Fazendo $c=-\log t_{0}$ e substituindo na equação (6), tem-se que o parâmetro de revenimento $P$ :

$$
P=T(c+\log t)
$$

A equação (7) ficou conhecida como o parâmetro de revenimento de Hollomon-Jaffe. Para calcular o valor da constante $c$ basta considerar que a mesma dureza pode ser alcançada por diferentes combinações de tempo e temperatura, gerando o mesmo valor para o parâmetro de revenimento:

$$
\begin{gathered}
P_{1}=P_{2} \\
T_{1}\left(c+\log t_{1}\right)=T_{2}\left(c+\log t_{2}\right)
\end{gathered}
$$

Isolando $C$ :

$$
-c=\frac{T_{1} \log t_{1}-T_{2} \log t_{2}}{T_{2}-T_{1}}
$$


ou

$$
\frac{T_{1}}{T_{2}}=\frac{c+\log t_{2}}{c+\log t_{1}}
$$

Ao utilizar a equação (7) para relacionar seus dados de dureza, tempo e temperatura de revenimento Holomon e Jaffe (1945) verificaram que o ajuste ficava em $\pm 1 \mathrm{HRC}$, exceto para os aços carbono com $0,97 \%$ de carbono e aços com austenita retida. Também observaram que o valor da constante $c$ variava para cada tipo de aço e que seu valor diminuía linearmente com a quantidade de carbono. Propuseram $c=19,5$ para os aços e ligas com quantidade de carbono variando de 0,25 a 0,4\%, e $c=15$ para aços ferramenta com teor de carbono entre 0,9 e 1,2\%. Verificaram também que quando não havia endurecimento secundário a dureza variava linearmente por um "intervalo considerável". A Figura 25 mostra um dos nomogramas obtidos neste estudo.

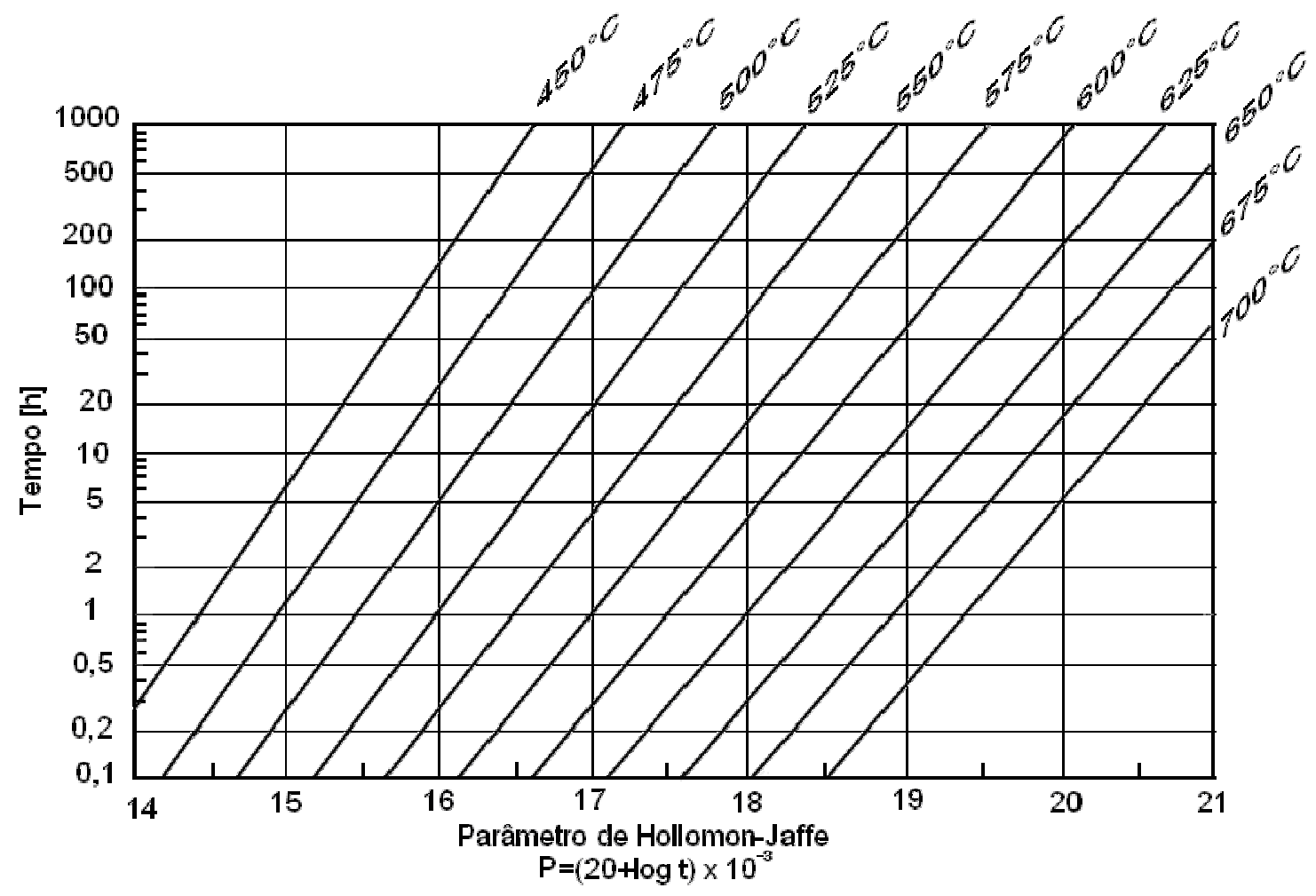

Figura 25: Nomograma ilustrando a relação tempo de revenimento, temperatura de revenimento e o parâmetro de Hollomon-Jaffe (Adaptado de Hollomon e Jaffe, 1945). 
Nehrenberg (1950) desenvolveu curvas de revenimento para os aços inoxidáveis e para o aço AISI 4340, como mostra a Figura 26. Baseado em dados experimentais e no trabalho de Hollomon e Jaffe (1945), Nehrenberg (1950) modificou o parâmetro de revenimento $P$ utilizado para predizer a dureza dos aços revenidos. A equação (12) apresenta tal modificação que consistiu apenas em atribuir um valor fixo para a constante $c$ igual a 20 :

$$
P=T(20+\log t)
$$

onde $T$ é a temperatura em escala absoluta e $t$ é tempo de revenimento em horas.

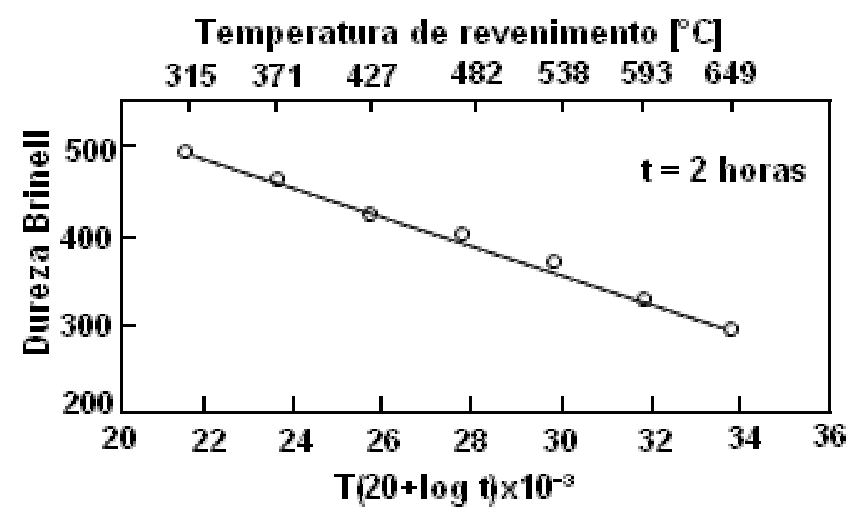

Figura 26: Curva mestre de revenimento para o aço AISI 4340 temperado em óleo após austenitização a $816^{\circ} \mathrm{C}$ (NEHRENBERG, 1950).

Larson e Miller (1952) estudaram o efeito do tempo e temperatura de revenimento nos dados de ruptura e de fluência para um aço de baixo carbono, um aço ligado com molibdênio, um aço ligado com cromo, dois tipos de aço inoxidável, um aço liga, uma liga não ferrosa e uma liga de titânio. Eles usaram a equação de Nehrenberg (1950), equação (12), com $c=20$. Numa percepção tardia a equação que ficou conhecida como de Lason-Miller deveria ter sido chamada de equação de Nehrenberg (CANALE et al., 2005). No entanto, Nehrenberg (1950) considerou a dureza como dependente do material, enquanto Larson e Miller (1952) assumiram que a relação era função da tensão de fluência e ruptura e não da dureza.

Quando a equação de Larson-Miller for utilizada para análise de dados de fluência a variável $T$ passa a ser a temperatura de teste e deve estar na escala a 
Rankine e $t$ passa a ser o tempo em horas necessário para a ruptura. A taxa de ruptura e a fluência são inversamente proporcionais ao tempo $(t)$ :

$$
r \propto 1 / t
$$

então:

$$
\frac{\Delta h}{R}=T(c+\log t)
$$

onde $\Delta h$ é a energia de ativação, $R$ a constante ideal dos gases, $t$ o tempo até a ruptura e $c=20$, como originalmente reportado por Nehrenberg (1950). Embora seja comum adotar 0 valor de $c=20$, pode-se assumir que 0 valor de $c$ em determinada tensão $(\sigma)$ pode ser calculado em duas temperaturas de teste $\left(T_{1}\right.$ e $\left.T_{2}\right)$ e o logt para cada temperatura usando a equação (10) e usando o parâmetro Larson-Miller calculado de $P=T(c+\log t)$ como mostra a Figura 27.

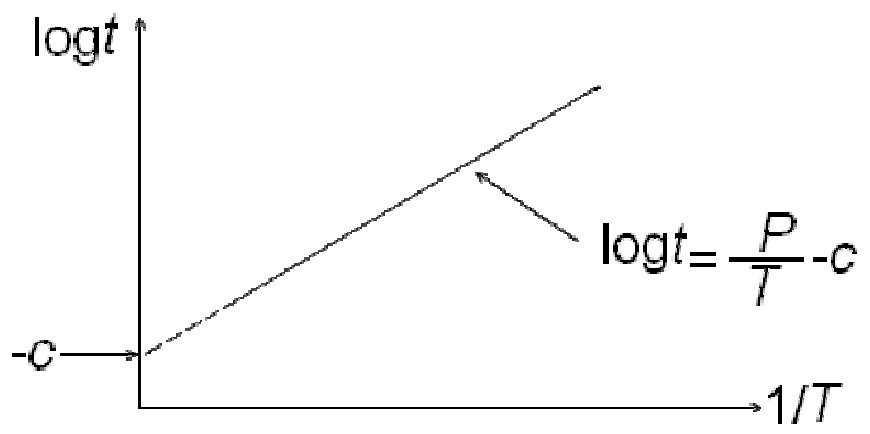

Figura 27: Determinação gráfica do parâmetro do material $c$ dos dados de ruptura (HUANG, 2003).

Grange e Baughman (1956) aplicaram os valores de $c$ reportados por Hollomon e Jaffe (1945) para uma enorme amostra de dados disponível na base de dados do Laboratório U.S. e concluíram que as variações de $c$ não eram críticas, mas poderiam variar muito, dependendo dos elementos de liga presentes no aço. A significância da variação do valor de $c$ fica evidente na Figura 28. Foi reportado que o melhor ajuste acontecia quando se utilizava $c=18$ e que a correlação melhorava usando a escala de dureza Vickers (que na época denominava-se dureza medida por pirâmide de diamante, com a sigla em inglês DPH). 


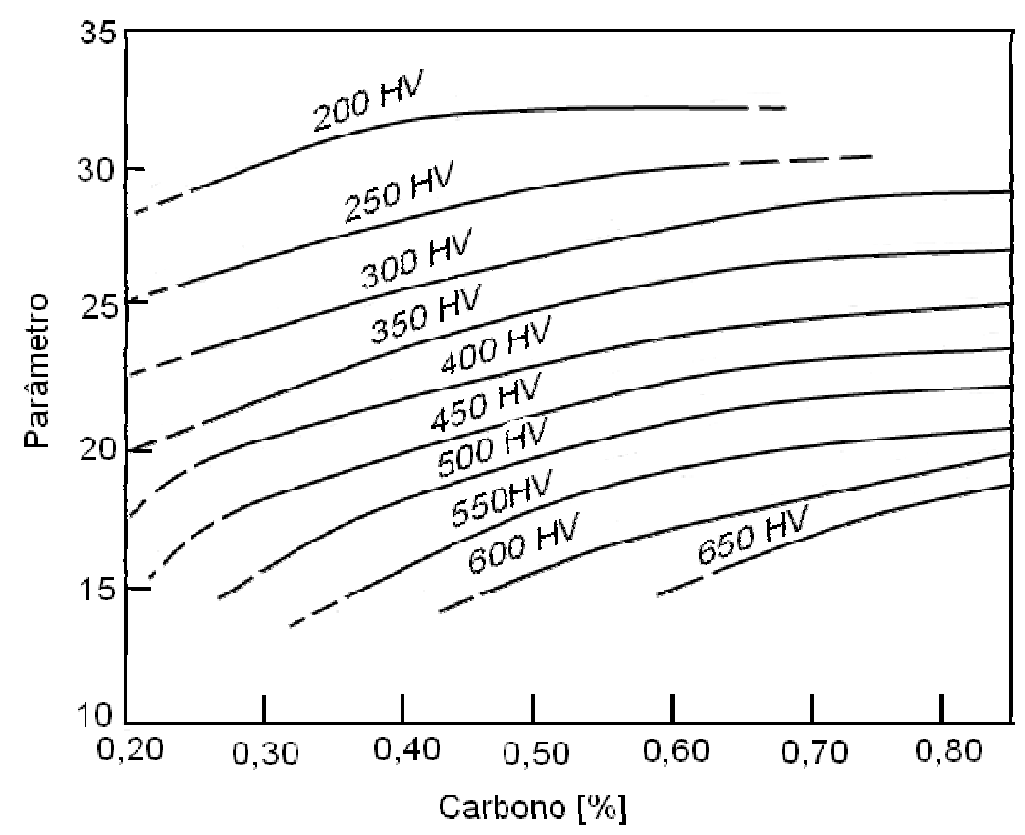

Figura 28: Variação da dureza em relação à quantidade de carbono (GRANGE e BAUGHMAN, 1956).

A Figura 29 mostra que usando $c=18$ há um melhor ajuste para uma série de aços carbono (AISI 1030, 1050 e 1080). À medida que a dureza diminui há uma tendência aparente das curvas se fundirem o que provavelmente acontece devido à formação de carbonetos coalescidos quando a dureza se aproxima daquela da ferrita.

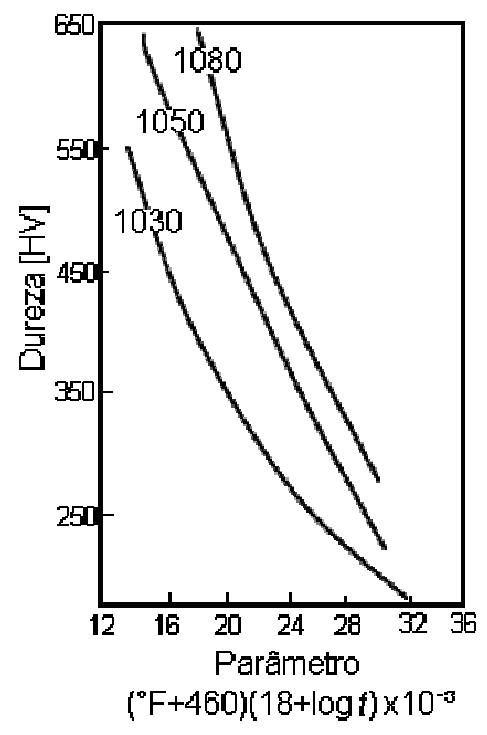

Figura 29: Curvas de revenimento para os aços carbono AISI 1030, 1050 e 1080 (GRANGE e BAUGHMAN, 1956). 
Grange e Baughman (1956) também mostraram que os elementos de liga afetam diferentemente o comportamento do aço revenido. A Figura 30 traz as curvas de revenimento para os aços AISI 4340 e AISI 5140. Para destacar o efeito do elemento de liga em cada figura também está presente uma curva de um aço carbono com quantidade de carbono similar. Foi estabelecido um método para calcular o incremento na dureza provocado pelos elementos de liga que consiste em somar a dureza do aço carbono com um "fator de liga" (expresso como incremento de dureza na escala Vickers, $\Delta \mathrm{HV}$ ). Observa-se que os dois aços devem conter a mesma quantidade de carbono. Tais fatores podem ser observados na Tabela 6, e o cálculo da dureza corrigida para o aço ligado é feito através da equação (14):

$$
H V_{\text {liga }}=\mathrm{HV}_{\text {aço carbono }}+\Delta \mathrm{HV}_{\mathrm{Mn}}+\Delta \mathrm{HV}_{\mathrm{P}}+\Delta \mathrm{HV}_{\mathrm{Si}}+\Delta \mathrm{HV}_{\mathrm{Ni}}+\Delta \mathrm{HV}_{\mathrm{Cr}}+\Delta \mathrm{HV}_{\mathrm{Mo}}+\Delta \mathrm{HV}_{\mathrm{V}}
$$

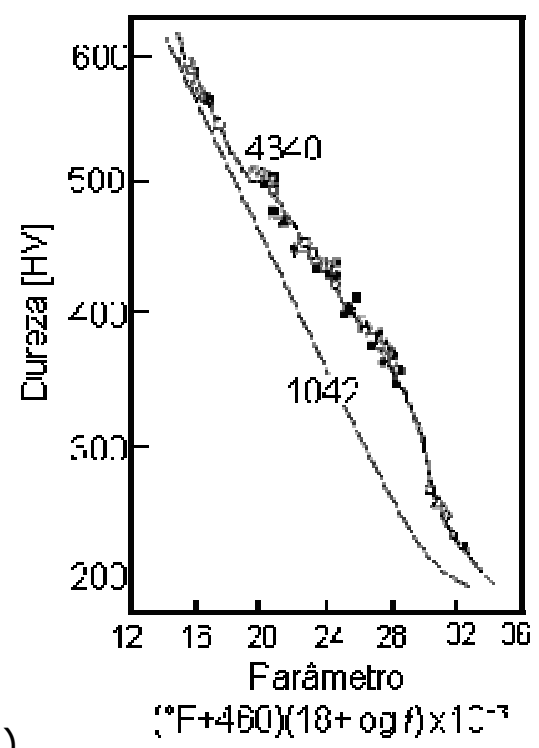

(a)

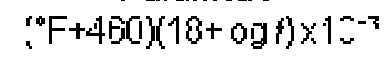

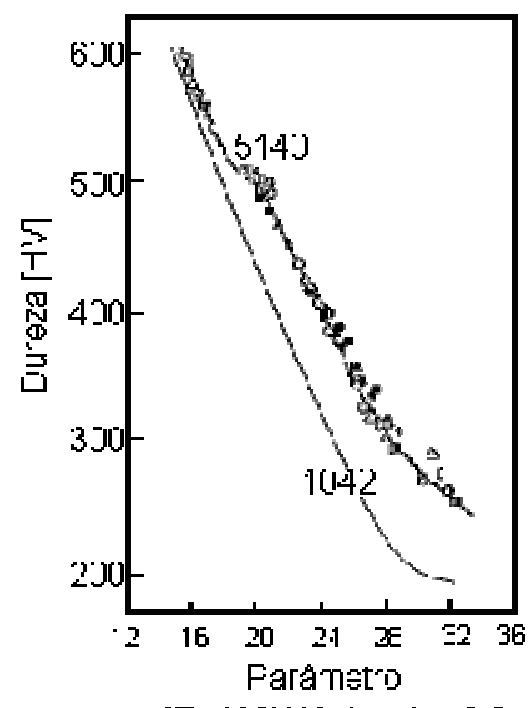

(b)

Figura 30: Curva de revenimento para os aços (a) AISI 4340 e (b) AISI 5140 (GRANGE e BAUGHMAN, 1956).

É possível citar ainda vários pesquisadores que se basearam no trabalho de Hollomon e Jaffe (1945). Manson e Haferd (1953) consideraram a tensão de fluência e de ruptura. Murphy e Whoodhead (1972) mostraram algumas limitações dos parâmetros existentes até então. Wan et al. (2005) desenvolveram um modelo matemático para calcular a dureza baseado no parâmetro de Hollomon e Jaffe. Zhang et al. (2004) descreveram cineticamente o amolecimento do aço durante o 
revenimento. E por fim, Filetin (1999) modelou curvas de revenimento para dois tipos de aços ferramenta utilizando redes neurais.

Tabela 6: Fatores para a previsão da dureza após o revenimento dos aços liga.

\begin{tabular}{lccccccc}
\hline Elemento & Intervalo & \multicolumn{7}{c}{ Fator de incremento $(\Delta \mathrm{HV})$} \\
\cline { 3 - 8 } & $(\%)$ & 20 & 22 & 24 & 26 & 28 & 30 \\
\hline $\mathrm{Mn}$ & $0.85-2.1$ & 35 & 25 & 30 & 30 & 30 & 25 \\
$\mathrm{Si}$ & $0.3-2.2$ & 65 & 60 & 30 & 30 & 30 & 30 \\
$\mathrm{Ni}$ & $\leq 4$ & 5 & 3 & 6 & 8 & 8 & 6 \\
$\mathrm{Cr}$ & $\leq 1.2$ & 50 & 55 & 55 & 55 & 55 & 55 \\
$\mathrm{Mo}$ & $\leq 0.35$ & 40 & 90 & 160 & 220 & 240 & 210 \\
& & $20^{2}$ & $45^{2}$ & $80^{2}$ & $110^{2}$ & $120^{2}$ & $105^{2}$ \\
$\mathrm{~V}^{1}$ & $\leq 0.2$ & 0 & 30 & 85 & 150 & 210 & 150 \\
\hline
\end{tabular}

1. Para aços AISI/SAE com cromo e vanádio, pode não ser aplicável quando o vanádio for o único formador de carboneto presente.

2. Se houver $\mathrm{Cr}$ entre 0,5 e $1,2 \%$ usar este fator.

Note que o fator do boro é 0 .

(GRANGE e BAUGHMAN, 1956).

Essa revisão dos parâmetros de revenimento ilustra que não há ainda um consenso neste sentido. Assim, a busca para outras soluções se justifica.

\subsection{REDES NEURAIS}

Para Haykin (1994) uma rede neural artificial (RNA) é um sistema massivamente paralelo e distribuído, composto por unidades de processamento simples que possuem uma capacidade natural de armazenar e utilizar conhecimento, sendo sua função aprender e manter um determinado modelo suficientemente consistente para alcançar os objetivos de uma aplicação de interesse. Esse sistema atua como um estimador de função não linear e não paramétrico que aprende a mapear entradas em saídas segundo uma superfície não-linear e multidimensional adequando-se a funções não lineares e multivariadas.

As RNAs não são programadas, mas sim treinadas. Devido a essa característica, elas são melhores aplicadas a problemas cujas soluções são difíceis de especificar, mas para os quais haja uma abundância de exemplos (SHEPPARD e GENT, 1991). Isto faz com que as RNAs sejam ideais para aplicações ricas em dados, mas pobres em teoria. Elas aprendem e desenvolvem soluções ajustando seu aprendizado de acordo com os exemplos e por meio das regras de aprendizagem. 
Essas regras de aprendizagem são algoritmos eficientes de computação para 0 descobrimento de transformações não lineares apropriadas entre o espaço do problema e o espaço das soluções.

As RNAs são também mais robustas do que os procedimentos sequênciais tradicionais. Devido a sua estrutura massivamente e paralelamente distribuída, o conhecimento é distribuído e armazenado através das interconexões gerando uma suave degradação em seu desempenho se os nós são destruídos. Essa característica de robustez também habilita a RNA a abstrair características essenciais de dados com ruídos, incompletos ou parcialmente incorretos.

As RNAs podem de fato representar muitos conceitos estatísticos. Um simples perceptron, por exemplo, tem uma forte associação com a análise discriminante. Um perceptron é um modelo que define um limite de decisão para as classes - 1 e 1 , sendo que este limite é sempre linear. Uma camada múltipla de perceptrons pode ser estatisticamente interpretada como uma função de regressão não-linear estimada pela otimização de alguma medida de ajuste dos dados de treinamento (como por exemplo, os mínimos quadrados). Os pesos representam os parâmetros de inclinação e o bias representa os pontos de interseção das retas com a origem. De uma forma similar, as RNAs têm uma versão para a análise estatística de clusters que se chama aprendizagem não supervisionada (CHENG e TITTERINTON, 1994).

Múltiplas camadas de perceptrons também conhecidos como rede de múltiplas camadas (MLP, sigla em inglês) podem separar os dados de entrada em várias categorias. Segundo Haykin (1994) uma MLP tem três características distintivas:

- O modelo de cada neurônio da rede inclui uma função de ativação nãolinear e diferenciável em qualquer ponto. Uma forma de nãolinearidade que satisfaz esta condição é uma não-linearidade sigmóide definida pela função logística:

$$
y_{j}=\frac{1}{1+\exp \left(-v_{j}\right)}
$$

onde $v_{j}$ é a soma ponderada de todas as entradas sinápticas acrescida do bias do neurônio $j$, e $y_{j}$ é a saída do neurônio. A presença da não-linearidade é importante porque, do contrário, a relação entrada-saída poderia ser reduzida àquela de um 
perceptron de camada única. Além disso, a utilização da função logística tem motivação biológica uma vez que tenta considerar a fase refratária do neurônio.

- A rede contém uma ou mais camadas de neurônios ocultos. Estes neurônios ocultos capacitam a rede a aprender tarefas complexas extraindo progressivamente as características mais significativas dos padrões (vetores) de entrada.

- A rede exibe um alto grau de conectividade, determinado pelas sinapses da rede. Uma modificação na conectividade da rede requer uma mudança na população das conexões sinápticas ou de seus pesos.

A Figura 31 mostra o gráfico da arquitetura de uma MLP com duas camadas ocultas e uma camada de saída. Observa-se que a rede é totalmente conectada. Isto significa que um neurônio em qualquer camada da rede está conectado a todos os neurônios da camada anterior. O fluxo de sinal através da rede progride para frente, da esquerda para a direita e de camada em camada.

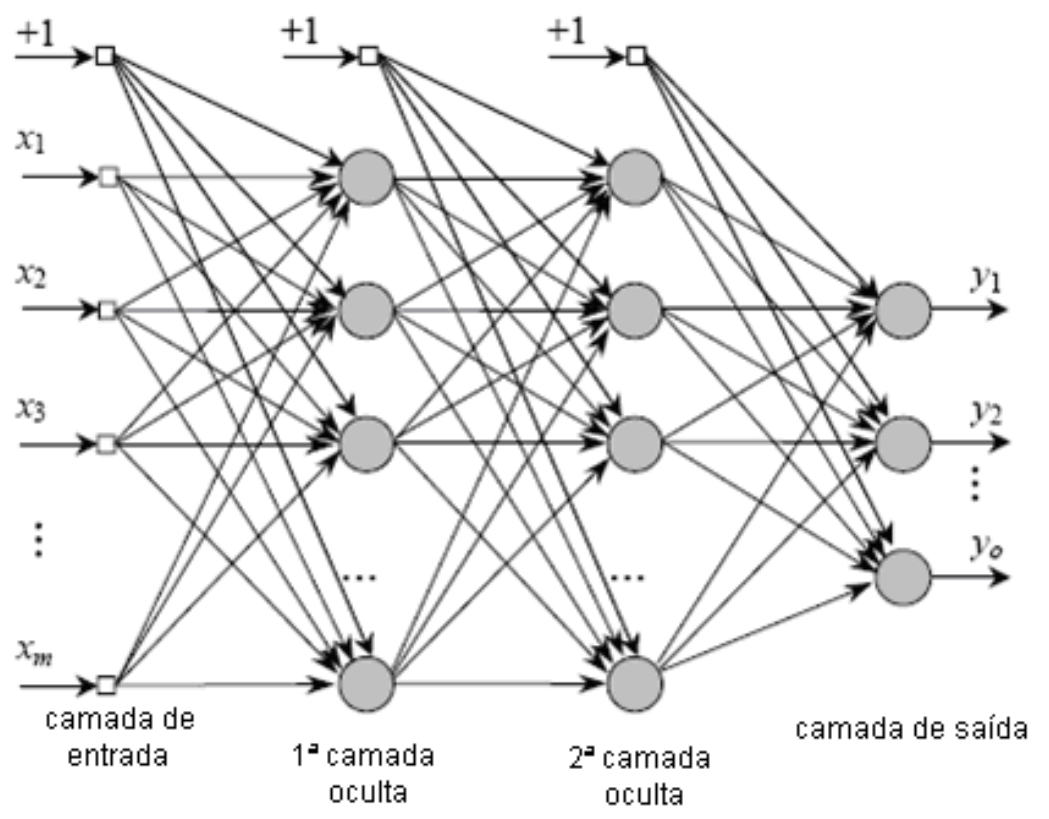

Figura 31: Gráfico da arquitetura de uma rede MLP com duas camadas ocultas (HAYKIN, 1994).

Uma vez que a rede é iniciada, os pesos e os biases são determinados, ou seja, começa o treinamento, para produzir a saída desejada. 0 treinamento muitas vezes é realizado diretamente com retropropagação. O conjunto de treinamento é 
repetidamente apresentado à rede e a saída da rede é comparada ao valor real (saída desejada). A cada iteração, ou época, o erro entre a saída da rede e a saída desejada é computado, normalmente pela média dos erros quadráticos. Este erro é utilizado para ajustar os pesos e biases da última camada, então da penúltima e assim por diante. Dependendo da natureza dos dados utilizados no conjunto de treinamento, a rede pode ser treinada adequadamente em poucas épocas ou centenas de iterações serão necessárias. As particularidades do algoritmo de retropropagação serão descritas na próxima seção.

\subsubsection{Redes de retropropagação}

As redes de retropropagação ou backpropagation são as RNAs mais populares. Uma rede de propagação direta com regra de aprendizagem baseada no algoritmo de retropropagação do erro é mostrada pela Figura 32. Segundo Haykin (1994) é possível identificar dois tipos de sinais nesta rede: um sinal funcional e um sinal de erro. Um sinal funcional ou sinal de entrada que incide no terminal da entrada da rede, propaga-se para frente, neurônio por neurônio, e emerge no terminal de saída da rede como um sinal de saída. É denominado sinal funcional porque ele realiza uma função útil na saída da rede e porque em cada neurônio através do qual ele passa, ele é calculado como uma função das entradas e dos pesos associados, aplicados aquele neurônio. O sinal de erro se origina na saída do neurônio da rede e se propaga para trás (camada por camada) através da rede. É chamado sinal de erro porque sua computação por cada neurônio da rede envolve uma função dependente do erro, de uma forma ou de outra.

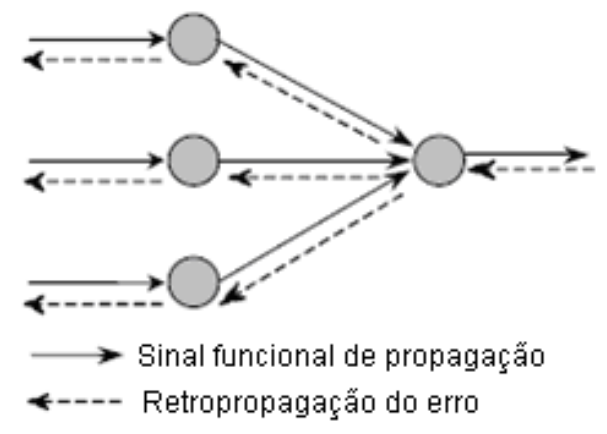

Figura 32: Direção dos dois sinais básicos em uma rede de retropropagação (HAYKIN, 1994). 
A seção anterior descreveu a parte de alimentação direta da rede. A retropropagação se refere ao método que ajusta ou corrige os pesos e os biases para produzir uma saída de rede coerente com o conjunto de treinamento. Deve-se salientar que o desempenho da rede depende da qualidade do conjunto de treinamento. Outra característica da rede de retropropagação é que as funções de ativação devem ser diferenciáveis.

Conforme descrito por Kessler (2005), uma iteração do algoritmo pode ser representada por:

$$
x_{k+1}=x_{k}-\eta_{k} g_{k}
$$

onde $x$ é um vetor que contém os pesos e biases, $g$ é o gradiente e $\eta$ a taxa de aprendizagem. Assim se faz necessário um índice de desempenho que indique 0 quanto a saída da rede se aproxima dos dados reais. A idéia é diminuir o erro médio quadrático (MSE, sigla em inglês) a cada iteração. O MSE ou $F(x)$ pode ser obtido pela comparação da saída da rede $(t)$ e dos valores medidos (a) e é dado por:

$$
F(x)=E\left(e^{2}\right)=E\left\lfloor(t-a)^{2}\right]
$$

onde

$$
x=\left[\begin{array}{l}
w \\
b
\end{array}\right]
$$

onde $w$ representa os pesos e $b$ os biases. Quando há múltiplas saídas o MSE é calculado por:

$$
F(x)=E\left(e^{T} e\right)=E\left\lfloor(t-a)^{T}(t-a)\right\rfloor
$$

que pode ser aproximada por:

$$
\hat{F}(x)=(t(k)-a(k))^{T}(t(k)-a(k))=e^{T}(k) e(k)
$$

onde a suposição do erro quadrático é substituída pelo erro quadrático na iteração $k$.

Para encontrar o erro mínimo utiliza-se o algoritmo do gradiente descendente que será mostrado a seguir: 


$$
\begin{gathered}
w_{i, j}^{m}(k+1)=w_{i, j}^{m}(k)-\eta \frac{\partial}{\partial w_{i, j}^{m}} \hat{F} \\
b_{i}^{m}(k+1)=b_{i}^{m}(k)-\eta \frac{\partial}{\partial b_{i}^{m}} \hat{F}
\end{gathered}
$$

As derivadas parciais das equações (21) e (22) são obtidas por:

$$
\begin{aligned}
& \frac{\partial}{\partial w_{i, j}^{m}} \hat{F}=\frac{\partial}{\partial n_{i}^{m}} \hat{F} \times \frac{\partial}{\partial w_{i, j}^{m}} n_{i}^{m} \\
& \frac{\partial}{\partial b_{i, j}^{m}} \hat{F}=\frac{\partial}{\partial n_{i}^{m}} \hat{F} \times \frac{\partial}{\partial b_{i, j}^{m}} n_{i}^{m}
\end{aligned}
$$

As derivadas parciais são usadas neste caso porque o erro é uma função indireta dos pesos e dos biases. Isto aparece apenas nas redes MLP. O segundo termo das equações (23) e (24) pode ser obtido por:

$$
n_{i}^{m}=\sum_{j=1}^{s^{m-1}} w_{i, j}^{m} a_{j}^{m-1}+b_{i}^{m}
$$

que resulta em:

$$
\frac{\partial}{\partial w_{i, j}^{m}} n_{i}^{m}=a_{j}^{m-1}, \frac{\partial}{\partial b_{i}^{m}} n_{i}^{m}=1
$$

A sensibilidade pode ser definida como:

$$
S_{i}^{m} \equiv \frac{\partial}{\partial n_{i}^{m}} \hat{F}
$$

Substituindo a equação (27) nas equações (25) e (26):

$$
\begin{gathered}
\frac{\partial}{\partial w_{i, j}^{m}} \hat{F}=s_{i}^{m} a_{j}^{m-1} \\
\frac{\partial}{\partial b_{i}^{m}} \hat{F}=s_{i}^{m}
\end{gathered}
$$

Agora, o algoritmo do gradiente descendente possa a ser representado por: 


$$
\begin{gathered}
w_{i, j}^{m}(k+1)=w_{i, j}^{m}(k)-\eta s_{i}^{m} a_{j}^{m-1} \\
b_{i}^{m}(k+1)=b_{i}^{m}(k)-\eta s_{i}^{m}
\end{gathered}
$$

ou na forma matricial:

$$
\begin{gathered}
W^{m}(k+1)=W^{m}(k)-\eta s^{m}\left(a^{m-1}\right)^{T} \\
b^{m}(k+1)=b^{m}(k)-\eta s^{m}
\end{gathered}
$$

As sensibilidades podem ser computadas. A relação periódica que existe entre a camada atual e a anterior é a idéia atrás da retropropagação. Para calcular a relação periódica é utilizada a matriz jacobiana:

$$
\frac{\partial n^{m+1}}{\partial n^{m}}=\left[\begin{array}{cccc}
\frac{\partial n_{1}^{m+1}}{\partial n_{1}^{m}} & \frac{\partial n_{1}^{m+1}}{\partial n_{2}^{m}} & \cdots & \frac{\partial n_{1}^{m+1}}{\partial n_{s^{m}}^{m}} \\
\frac{\partial n_{2}^{m+1}}{\partial n_{1}^{m}} & \frac{\partial n_{2}^{m+1}}{\partial n_{2}^{m}} & \cdots & \frac{\partial n_{21}^{m+1}}{\partial n_{s^{m}}^{m}} \\
\vdots & \vdots & \ddots & \vdots \\
\frac{\partial n_{s^{m+1}}^{m+1}}{\partial n_{1}^{m}} & \frac{\partial n_{s^{m+1}}^{m+1}}{\partial n_{2}^{m}} & \cdots & \frac{\partial n_{s^{m+1}}^{m}}{\partial n_{s^{m}}^{m}}
\end{array}\right]
$$

Se faz necessário uma expressão para a matriz, então considerando os elementos $i, j$ da matriz:

$$
\frac{\partial n_{i}^{m+1}}{\partial n_{j}^{m}}=\frac{\partial}{\partial n_{j}^{m}}\left(\sum_{l=1}^{s^{m}} w_{i, l}^{m+1} a_{l}^{m}+b_{i}^{m+1}\right)=w_{i, j}^{m+1} \frac{\partial a_{j}^{m}}{\partial n_{j}^{m}}=w_{i, j}^{m+1} \frac{\partial}{\partial n_{j}^{m}} f^{m}\left(n_{j}^{m}\right)
$$

fazendo

$$
\dot{f}^{m}\left(n_{j}^{m}\right)=\frac{\partial}{\partial n_{j}^{m}} f^{m}\left(n_{j}^{m}\right)
$$

e substituindo a equação (36) na equação (35):

$$
\frac{\partial n_{i}^{m+1}}{\partial n_{j}^{m}}=w_{i, j}^{m+1} \dot{f}^{m}\left(n_{j}^{m}\right)
$$

que permite que o jacobiano: 


$$
\frac{\partial n_{i}^{m+1}}{\partial n_{j}^{m}}=W^{m+1} \dot{F}^{m}\left(n^{m}\right)
$$

onde

$$
\dot{F}^{m}\left(n^{m}\right)=\left[\begin{array}{cccc}
\dot{f}^{m}\left(n_{1}^{m}\right) & 0 & \cdots & 0 \\
0 & \dot{f}^{m}\left(n_{2}^{m}\right) & \cdots & 0 \\
\vdots & \vdots & \ddots & \vdots \\
0 & 0 & \cdots & \dot{f}^{m}\left(n_{s^{m}}^{m}\right)
\end{array}\right]
$$

Assim a relação para a sensibilidade pode ser escrita da seguinte forma:

$$
S^{m}=\dot{F}^{m}\left(n^{m}\right)\left(W^{m+1}\right)^{T} S^{m+1}
$$

Neste ponto fica evidente que as sensibilidades foram encontradas pela retropropagação da última camada para a primeira. O ponto de início, $s^{m}$, também deve se encontrado usando a camada final.

$$
s_{i}^{M}=\frac{\partial}{\partial n_{i}^{M}} \hat{F}=\frac{\partial}{\partial n_{i}^{M}}(t-a)^{T}(t-a)=\frac{\partial}{\partial n_{i}^{M}} \sum_{j=1}^{s^{M}}\left(t_{j}-a_{j}\right)^{2}=-2\left(t_{i}-a_{i}\right) \frac{\partial a_{i}}{\partial n_{i}^{M}}
$$

Agora usando a relação

$$
\frac{\partial a_{i}}{\partial n_{i}^{M}}=\frac{\partial a_{i}^{M}}{\partial n_{i}^{M}}=\frac{\partial}{\partial n_{i}^{M}} f^{M}\left(n_{i}^{M}\right)=\dot{f}^{M}\left(n_{i}^{M}\right)
$$

substituindo

$$
s_{i}^{M}=-2\left(t_{i}-a_{i}\right) \dot{f}^{M}\left(n_{i}^{M}\right)
$$

ou na forma matricial

$$
s^{M}=-2 \dot{F}^{M}\left(n^{M}\right)(t-a)
$$

Finalmente, todas as equações necessárias para executar a retropropagação foram desenvolvidas.

O treinamento é um processo que consiste em repetir este algoritmo até que o erro se torne aceitável ou algum outro critério seja alcançado. Primeiramente se determina os pesos e biases. Então as variáveis de entrada são propagadas pela rede e baseada no erro produzido, equação (44) a sensibilidade é calculada na 
última camada usando a equação (40). Os pesos são atualizados pela equação (33) e os biases pela equação (32).

\subsubsection{Algoritmo de Levenberg-Marquardt}

O algoritmo de Levenberg-Marquardt (LM) é um tipo de algoritmo de retropropagação que emprega uma variação do método de Newton. A descrição completa deste método foi feita por Hagan e Menhaj (1994) e também foi reproduzida por Kessler (2005). Enquanto o algoritmo de retro-propagação está baseado na expansão da série de Taylor de primeira ordem, o método de Newton utiliza uma série de Taylor de segunda ordem:

$$
F\left(x_{k+1}\right) \approx F\left(x_{k}+\Delta x_{k}\right) \approx F\left(x_{k}\right)+g_{k}^{T} \Delta x_{k}+\frac{1}{2} \Delta x_{k}^{T} A_{k} \Delta x_{k}
$$

Calculando o gradiente da equação (45) em relação a $\Delta x_{k}$ e igualando a zero tem-se:

$$
g_{k}+A_{k} \Delta x_{k}=0
$$

isolando $\Delta x_{k}$

$$
\Delta x_{k}=-A_{k}^{-1} g_{k}
$$

Então, define-se o método de Newton como:

$$
x_{k+1}=x_{k}-A_{k}^{-1} g_{k}
$$

onde o gradiente e a matriz hessiana são definidos como as equações (46) e (47) respectivamente:

$$
\begin{gathered}
\left.g_{k} \equiv \nabla F(x)\right|_{x=x_{k}} \\
\left.A_{k} \equiv \nabla^{2} F(x)\right|_{x=x_{k}}
\end{gathered}
$$

Assumindo que $F(x)$ é a função objetivo e tem a forma da soma dos quadrados:

$$
F(x)=\sum_{i=1}^{N} v_{i}^{2}(x)=v^{T}(x) v(x)
$$


considerando o j-ésimo elemento do gradiente:

$$
[\nabla F(x)]_{j}=\frac{\partial}{\partial x_{j}} F(x)=2 \sum_{i=1}^{N} v_{i}(x) \frac{\partial}{\partial x_{j}} v_{i}(x)
$$

Escrevendo o gradiente na forma matricial:

$$
\nabla F(x)=2 J^{T}(x) v(x)
$$

onde

$$
J(x)=\left[\begin{array}{cccc}
\frac{\partial}{\partial x_{1}} v_{1}(x) & \frac{\partial}{\partial x_{2}} v_{1}(x) & \cdots & \frac{\partial}{\partial x_{n}} v_{1}(x) \\
\frac{\partial}{\partial x_{1}} v_{2}(x) & \frac{\partial}{\partial x_{2}} v_{2}(x) & \cdots & \frac{\partial}{\partial x_{n}} v_{2}(x) \\
\vdots & \vdots & \ddots & \vdots \\
\frac{\partial}{\partial x_{1}} v_{n}(x) & \frac{\partial}{\partial x_{2}} v_{n}(x) & \cdots & \frac{\partial}{\partial x_{n}} v_{n}(x)
\end{array}\right]
$$

Como o método de Newton é de segunda ordem, a matriz hessiana pode ser aproximada como:

$$
\left[\nabla^{2} F(x)\right]_{k, j}=\frac{\partial^{2}}{\partial x_{k} \partial x_{j}} F(x)=2 \sum_{i=1}^{N}\left\{\frac{\partial}{\partial x_{k}} v_{i}(x) \frac{\partial}{\partial x_{j}} v_{i}(x)+v_{i}(x) \frac{\partial^{2}}{\partial x_{k} \partial x_{j}} v_{i}(x)\right\}
$$

ou na forma matricial

$$
\nabla^{2} F(x)=2 J^{T}(x) J(x)+2 S(x)
$$

onde

$$
s(x)=\sum_{i=1}^{N} v_{i}(x) \nabla^{2} v_{i}(x)
$$

0 método Gauss-Newton assume que $s(x) \approx 0$, então a matriz hessiana pode ser escrita como:

$$
\nabla^{2} F(x) \cong 2 J^{T}(x) J(x)
$$

O método de Gauss-Newton resulta da substituição das equações (58) e (53) na equação (48): 


$$
\begin{gathered}
x_{k+1}=x_{k}-\left[2 J^{T}\left(x_{k}\right) J\left(x_{k}\right)\right]^{-1} 2 J^{T}\left(x_{k}\right) e\left(x_{k}\right)=x_{k}-\left[J^{T}\left(x_{k}\right) J\left(x_{k}\right)\right]^{-1} J^{T}\left(x_{k}\right) e\left(x_{k}\right) \\
\Delta x=\left[J^{T}(x) \cdot J(x)\right]^{-1} J^{T}(x) \cdot e(x)
\end{gathered}
$$

Nota-se na equação (60) que apenas a matriz jacobiana permanece no método de Gauss-Newton, e pelo fato da matriz hessiana ter sido eliminada a eficiência computacional é melhorada, uma vez que não se faz mais necessário o cálculo das derivadas de segunda ordem.

0 método de LM modifica o Gauss-Newton ao incluir um fator $\mu$ responsável pelo ajuste do tamanho do incremento realizado pelo algoritmo, como mostra a equação (61):

$$
\Delta x=\left[J^{T}(x) \cdot J(x)+\mu l\right]^{-1} J^{T}(x) \cdot v(x)
$$

Assim, quando $\mu$ aumenta o algoritmo se aproxima do método do gradiente descendente e quando o valor de $\mu$ se aproxima de zero, o algoritmo se torna GaussNewton.

Portanto o algoritmo LM é similar ao de retro-propagação tradicional, exceto pelo fato que o jacobiano agora é determinado pelas derivativas de primeira ordem dos pesos, biases e erros da rede, como mostra a equação (62).

$$
J(x)=\left[\begin{array}{ccccc}
\frac{\partial e_{1,1}}{\partial w_{1,1}^{1}} \frac{\partial e_{1,1}}{\partial w_{1,2}^{1}} & \cdots & \frac{\partial e_{1,1}}{\partial w_{S^{1}, R}^{1}} \frac{\partial e_{1,1}}{\partial b_{1}^{1}} & \cdots \\
\frac{\partial e_{2,1}}{\partial w_{1,1}^{1}} \frac{\partial e_{2,1}}{\partial w_{1,2}^{1}} & \cdots & \frac{\partial e_{2,1}}{\partial w_{S^{1}, R}^{1}} \frac{\partial e_{2,1}}{\partial b_{1}^{1}} & \cdots \\
\cdots & \cdots & \cdots & \cdots \\
\frac{\partial e_{S^{M}, 1} \frac{\partial e_{S^{M}, 1}}{\partial w_{1,1}^{1}} \frac{\partial w_{1,2}^{1}}{\partial w_{S^{M}, 1}}}{\cdots} & \frac{\partial e_{S^{M}, 1}}{\partial w_{S^{1}, R}^{1}} & \cdots \\
\frac{\partial e_{1,2}^{1}}{\partial w_{1,1}^{1}} \frac{\partial e_{1,2}}{\partial w_{1,2}^{1}} & \cdots & \frac{\partial e_{1,2}^{1}}{\partial w_{S^{1}, R}^{1}} \frac{\partial e_{1,2}}{\partial b_{1}^{1}} & \cdots \\
\cdots & \cdots & { }_{\cdots} & \cdots
\end{array}\right]
$$

Para utilizar este algoritmo nas redes MLP, deve-se calcular o termo de sensibilidade é obtido por 


$$
S_{i, h}^{\sim m} \equiv \frac{\partial v_{h}}{\partial n_{i, q}^{m}}=\frac{\partial e_{k, q}}{\partial n_{i, q}^{m}}
$$

onde

$$
h=(q-1) S^{M}+k
$$

Ao definir a sensibilidade desta forma, os termos da matriz jacobiana para os pesos podem ser calculados mais facilmente:

$$
[J]_{h, 1}=\frac{\partial v_{h}}{\partial x_{1}}=\frac{\partial e_{k, q}}{\partial w_{i, j}^{m}}=\frac{\partial e_{k, q}}{\partial n_{i, q}^{m}} \times \frac{\partial n_{i, q}^{m}}{\partial w_{i, j}^{m}}=s_{i, h}^{\sim m} \times \frac{\partial n_{i, q}^{m}}{\partial w_{i, j}^{m}}=s_{i, j}^{\sim m} \times a_{j, q}^{m-1}
$$

ou para os biases

$$
[J]_{h, l}=\frac{\partial v_{h}}{\partial x_{l}}=\frac{\partial e_{k, q}}{\partial b_{i}^{m}}=\frac{\partial e_{k, q}}{\partial n_{i, q}^{m}} \times \frac{\partial n_{i, q}^{m}}{\partial b_{i}^{m}}=\boldsymbol{s}_{i, h}^{\sim m} \times \frac{\partial n_{i, q}^{m}}{\partial b_{i}^{m}}=\boldsymbol{s}_{i, h}^{\sim m}
$$

De forma análoga, para a camada final:

$$
\boldsymbol{s}_{i, h}^{\sim M} \equiv \frac{\partial v_{h}}{\partial n_{i, q}^{M}}=\frac{\partial e_{k, q}}{\partial n_{i, q}^{M}}=\frac{\partial}{\partial n_{i, q}^{M}}\left(t_{k, q}-a_{k, q}^{M}\right)=\frac{\partial a_{k, q}^{M}}{\partial n_{i, q}^{M}}=\left(\begin{array}{c}
-f^{m}\left(n_{i, q}^{m}\right), \text { se } i=k \\
0, \text { se } i \neq k
\end{array}\right)
$$

Assim, pode-se iniciar a rede por:

$$
S_{q}^{\sim M}=-F^{M}\left(n_{q}^{M}\right)
$$

onde o lado direito é definido pela equação (39). As colunas da matriz $s_{q}^{\sim M}$ são retropropagadas pela rede usando a equação (40) para produzir uma linha do jacobiano.

As colunas também podem ser retro-propagadas simultaneamente por

$$
S_{q}^{\sim m}=F^{m}\left(n_{q}^{m}\right)\left(W^{m+1}\right) S_{q}^{\sim m+1}
$$

As matrizes de sensibilidade total para cada camada no método de Marquardt são formadas acrescentando cada matriz de entrada

$$
S^{\sim m}=\left\lfloor S_{1}^{\sim m}\left|S_{2}^{\sim m}\right| \ldots S_{Q}^{\sim m}\right]
$$

O algoritmo LM pode ser resumido da seguinte forma:

- Especificam-se os pesos e biases

- Os sinais de entrada são propagados pela rede 
- É calculada a soma dos erros quadráticos pela equação (51)

- É computado o jacobiano pela equação (62) e as sensibilidades pelas equações (69) e (63)

- Atualizam-se os pesos e biases pelas equações (65) e (66)

- Resolve a equação (61) para encontrar $\Delta x_{k}$

- Recalcula-se o erro médio quadrático, que se for menor que o erro anterior, computa-se $\frac{\mu}{v}$ e deixa $x_{k+1}=x_{k}+\Delta x_{k}$ e se a soma não for reduzida, então se multiplica $\mu$ por $\nu$ e retorna ao passo anterior.

\subsubsection{Pré-processamento dos dados de entrada}

As funções sigmóides se caracterizam pela presença de saturação, ou seja, para valores muito grandes de seu argumento elas estarão operando na região saturada da curva (MATHWORKS, 2008). Por este motivo é importante normalizar os dados de entrada em um intervalo pré-definido, por exemplo, $[0,1]$ ou $[-1,1]$. A equação (71) permite normalizar os dados de entrada no intervalo $[-1,1]$ e a equação (72) em um intervalo de média zero e desvio padrão unitário.

$$
\begin{gathered}
x_{n}=\frac{x-x_{\min }}{x_{\max }-X_{\min }}-\frac{1}{2} \\
x_{n}=\sigma x_{i}+\bar{x}
\end{gathered}
$$

\subsubsection{Arquitetura da rede}

Segundo De Castro (1998) a quantidade de neurônios na camada de entrada é definida pelo problema, no entanto a quantidade de neurônios nas camadas intermediárias de saída é uma característica do projeto.

Sabe-se que quanto maior a quantidade de neurônios na camada oculta, maior a capacidade de mapeamento não-linear da rede MLP. No entanto a presença de ruído nas amostras de treinamento podem ocasionar um sobre-ajustamento dos dados. Uma rede com poucos neurônios na camada oculta pode não ser capaz de aproximar a função adequadamente, causando um sub-ajustamento. 
Para evitar o sobre-ajustamento além de dimensionar a camada oculta corretamente, pode-se utilizar mais duas técnicas durante o treinamento. São elas a regularização e validação cruzada, que serão explicadas nas próximas seções.

\subsubsection{Regularização bayesiana}

A regularização é um método utilizado para melhorar a capacidade de generalização da rede. Este método consiste na restrição dos valores dos pesos, possibilitando uma suavização da saída da rede.

A regularização bayesiana adiciona um termo a função de desempenho, ou erros quadráticos, usado anteriormente. Se $E_{D}$ representa o erro quadrático e $E_{w}$ a soma dos pesos quadráticos, então a função de desempenho modificada pode ser expressa por:

$$
F=\beta E_{D}+\alpha E_{w}
$$

onde $\alpha$ e $\beta$ são os parâmetros da função objetivo. Se $\alpha<<\beta$ os erros da rede serão menores. No entanto se $\alpha>>\beta$ os valores dos pesos serão minimizados, produzindo uma saída mais suave e consequentemente melhorando a generalização (DAN FORESEE e HAGAN, 1997).

\subsubsection{Validação cruzada}

Esta técnica, conforme descrito por Kessler (2005), consiste em dividir o conjunto dados em três partes: treinamento, teste e validação, interrompendo o treinamento antes que ocorra o sobre-ajustamento. Ou seja, enquanto a rede treina o conjunto destinado ao treinamento ela também avalia o conjunto de validação em cada iteração. No momento em que o erro do conjunto de validação for superior ao erro obtido nas iterações anteriores, o treinamento é interrompido. A Figura 33 mostra o momento em que o sobre-ajustamento acontece. Geralmente, o erro de validação é uma estimativa do erro de generalização. 


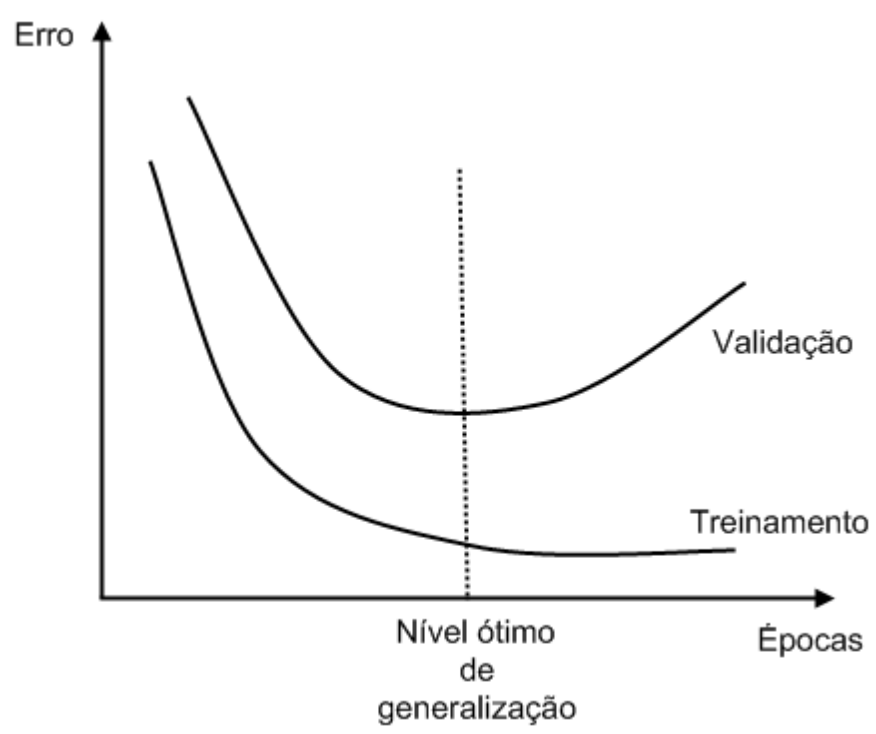

Figura 33: Idéia da validação cruzada (HAYKIN, 1994).

Utilizando-se da técnica descrita o presente trabalho, busca as soluções para a predição das propriedades mecânicas obtidas após o revenimento dentro do universo das redes neurais. 


\section{MATERI AIS E MÉTODOS}

Este trabalho está baseado em uma modelagem experimental. Ou seja, em um primeiro momento foram realizados testes reais de dureza e de tração que depois serviram de base para a construção de uma rede neural artificial que foi construída para calcular estes mesmos valores em função da composição química, da temperatura de revenimento e do tempo de revenimento. A modelagem foi feita utilizando o programa MatLab.

\subsection{MATERI AIS UTI LI ZADOS}

Cinco aços para beneficiamento foram escolhidos para realizar os testes. A designação dos aços e a composição química de cada um podem ser observadas na Tabela 7. São aços com ampla faixa de utilização e apesar de apresentarem elementos de liga, não sofrem o endurecimento secundário.

Tabela 7: Composição química dos aços ensaiados

\begin{tabular}{lllllllll}
\hline Aço & $\% \mathrm{C}$ & $\% \mathrm{Mn}$ & $\% \mathrm{P}$ & $\% \mathrm{~S}$ & $\% \mathrm{Si}$ & $\% \mathrm{Ni}$ & $\% \mathrm{Cr}$ & $\% \mathrm{Mo}$ \\
\hline AISI 4140 & 0,41 & 0,88 & 0,016 & 0,018 & 0,23 & - & 1,02 & 0,22 \\
AISI 4340 & 0,39 & 0,75 & 0,019 & 0,016 & 0,26 & 1,74 & 0,79 & 0,26 \\
AISI 5160 & 0,62 & 0,88 & 0,012 & 0,018 & 0,22 & - & 0,79 & - \\
AISI 6150 & 0,51 & 0,81 & 0,021 & 0,014 & 0,28 & - & 0,98 & - \\
AISI E52100 & 1,02 & 0,40 & 0,017 & 0,014 & 0,23 & - & 1,42 & - \\
\hline
\end{tabular}

\subsection{TRATAMENTO TÉRMI CO}

Os corpos de prova de tração, $\phi=6 \mathrm{~mm}$, foram temperados em um óleo mineral convencional, sem agitação e a $60^{\circ} \mathrm{C}$. Seguindo os procedimentos estabelecidos pela norma ASTM D6200 - 07, verificou-se que se trata de um óleo com taxa máxima de resfriamento de $90^{\circ} \mathrm{C} / \mathrm{s}$ a $514^{\circ} \mathrm{C}$. As temperaturas de austenitização respeitaram os limites estabelecidos por Harvey (1982) e foi igual a $850^{\circ} \mathrm{C}$ para todos os aços. $\mathrm{O}$ tempo nesta temperatura foi igual a duas horas. Durante este processo os 
corpos de prova foram colocados em uma caixa com carvão com o objetivo de se evitar a descarbonetação.

A princípio, o tratamento de revenimento foi realizado em 9 temperaturas e em 5 tempos diferentes, com resfriamento ao ar. As temperaturas utilizadas foram: 100, 150, 200, 250, 300, 400, 500, 600 e $700^{\circ} \mathrm{C}$. O tempo em cada temperatura foi de 10, 90, 900, 9000 e 86400 s. Durante o processo a temperatura do forno variou em $\pm 10^{\circ} \mathrm{C}$, e 0 tempo foi contado após o encharque do corpo de prova. No entanto para o ensaio de tração foram descartados os aços revenidos por 10s a 100, 150, 200, 250 e $300^{\circ} \mathrm{C}$, que foram substituídos por amostras revenidas a 250,300, 400, 500, 600 e $700^{\circ} \mathrm{C}$ durante 1 hora. Tal decisão foi necessária devido à alta dureza obtida pelos corpos de prova revenidos por 10 s nas temperaturas mais baixas, cujos resultados de tração não correspondiam à realidade provavelmente devido à fragilidade da martensita, conforme relatado por Brooks, (1996). Os ensaios de dureza por sua vez seguiram normalmente. A Tabela 8 mostra os fatores e níveis a serem ensaiados.

Tabela 8: Fatores e níveis a serem ensaiados

\begin{tabular}{|c|c|}
\hline Fatores & Níveis \\
\hline Aço & $\begin{array}{c}\text { AISI 4140, AISI 4340, AISI 5160, AISI } 6150 \\
\text { e AISI E52100 }\end{array}$ \\
\hline $\begin{array}{l}\text { Temperatura de } \\
\text { revenimento }[\underline{\circ} \mathrm{C}]\end{array}$ & $\begin{array}{c}100,150,200,250,300,400,500,600 \mathrm{e} \\
700\end{array}$ \\
\hline $\begin{array}{l}\text { Tempo de revenimento [s] } \\
\text { Replicância }\end{array}$ & $\begin{array}{c}10,90,900,3600,9000 \text { e } 86300 \\
3\end{array}$ \\
\hline
\end{tabular}

Assim, foi gerado um total de 741 corpos de prova para realizar os testes de dureza e de tração produzindo dados que posteriormente seriam utilizados no treinamento e teste das redes neurais.

\subsection{MEDI DAS DE DUREZA}

As medidas de dureza foram feitas na superfície do corpo de prova. O durômetro utilizado foi o modelo LECO RT-240, com carregamento de 150 kgf e de 100 kgf, para medições nas escalas Rockwell C (HRC) e 
Rockwell B (HRB) respectivamente. Este equipamento possui uma função que permite a conversão da escala HRC em escala Vickers (HV) automaticamente. Para a conversão dos dados de HRB em HV foi utilizada a norma ASTM E 140 - 07. Decidiu-se trabalhar na escala Vickers com o objetivo de facilitar a manipulação dos dados obtidos. Em cada amostra foram realizadas 5 medições ao longo da superfície do corpo de prova. Observa-se que não houve descarbonetação nas peças, e que por este motivo pode-se escolher a superfície e não a seção transversal como é praxe para realizar as medidas.

\subsection{ENSAI O DE TRAÇÃO}

Os ensaios de tração seguiram a norma da ASTM E 8M (2004). O teste foi conduzido utilizando replicância igual a 3. As dimensões do corpo de prova podem ser observadas na Figura 34. O ensaio realizado na máquina MTS, com célula de carga de $100 \mathrm{kN}$ e $\dot{\varepsilon}=0,8 \mathrm{~mm} / \mathrm{s}$, consiste na aplicação de uma carga crescente até a ruptura do corpo de prova.

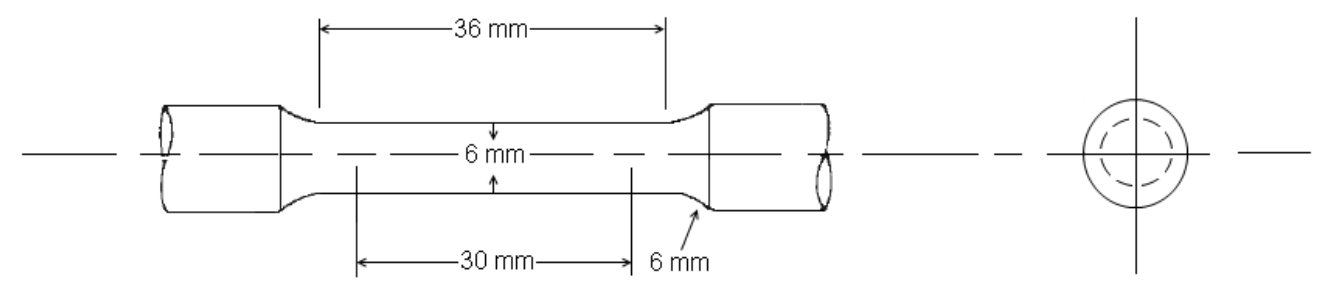

Figura 34: Corpo de prova cilíndrico para teste de tração de materiais metálicos.

Os resultados obtidos são curvas, como as exemplificadas pela Figura 35, as quais são denominadas curvas tensão-deformação ( $\sigma-\varepsilon$ ) de onde é possível extrair propriedades mecânicas tais como: limite de resistência à tração (LRT), limite de escoamento (LE), tensão de ruptura $\left(\sigma_{r}\right)$, módulo de elasticidade $(E)$, módulo de tenacidade $\left(U_{t}\right)$ e módulo de resiliência $\left(U_{r}\right)$. A extração de todos estes dados das curvas obtidas seguiu 
os procedimentos descritos pela norma ASTM 8M - 04 e pelo manual da ASM (2000) para testes mecânicos e serão descritos a seguir.

O limite de resistência à tração e a tensão de ruptura podem ser extraídos diretamente da curva tensão-deformação. Para os materiais dúcteis o limite de escoamento é facilmente identificado como mostra a Figura 35 (a). O limite de escoamento corresponde à tensão máxima onde o material ainda obedece à lei de Hooke, ou seja, ainda apresenta um comportamento elástico. Quando o limite de escoamento não está evidente considera-se o limite de escoamento convencional, que corresponde à tensão obtida na deformação de 0,2\%, como mostra a Figura 35 (b).
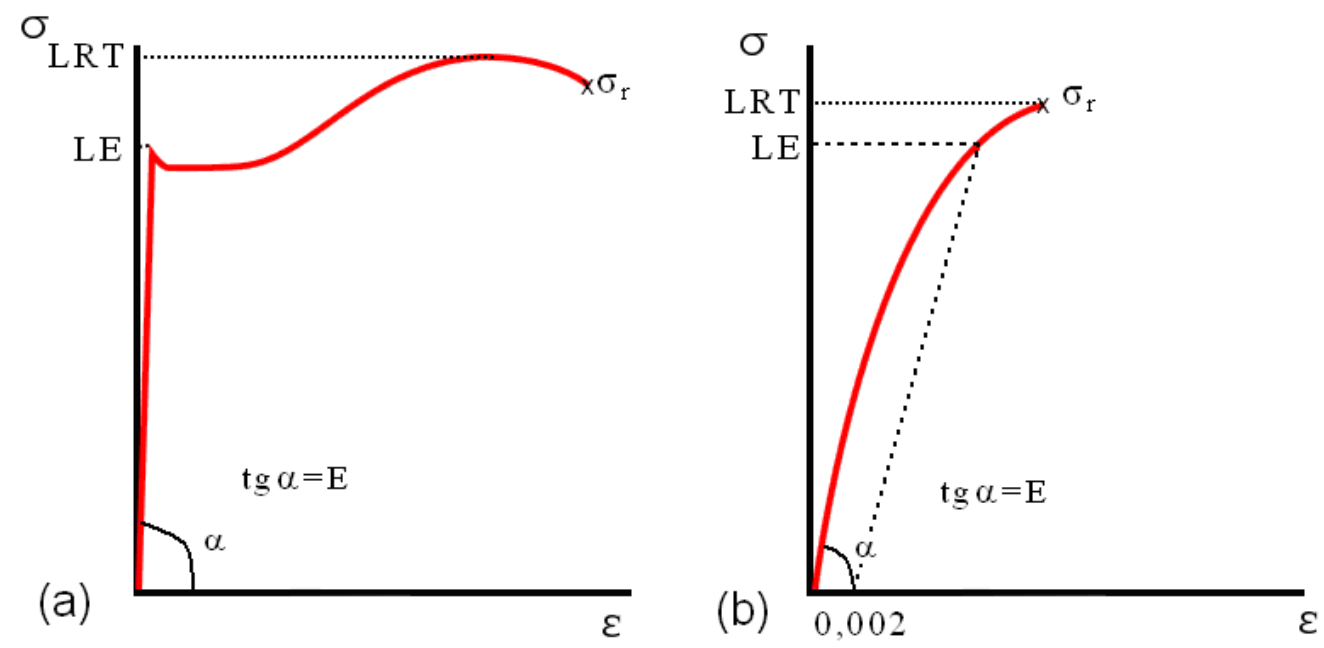

Figura 35: Curvas típicas de tração obtidas para um material (a) dúctil e para um (b) frágil.

O módulo de elasticidade, também conhecido como módulo de Young, indica a rigidez do material. Quanto maior o valor de $E$, maior a rigidez do material. Esta propriedade é obtida na região do gráfico onde material obedece à lei de Hooke e corresponde a tangente do ângulo $\alpha$ (Figura 35), podendo ser obtida pela equação:

$$
\mathrm{E}=\frac{\sigma}{\varepsilon}=\operatorname{tg} \alpha
$$


O módulo de tenacidade indica a capacidade de absorção de energia até a fratura e corresponde a área total do gráfico $\sigma-\varepsilon$. Esta área indica a quantidade de trabalho por unidade de volume no material, sem causar sua ruptura. Quanto maior a área abaixo da curva $\sigma-\varepsilon$, mais tenaz é o material. A tenacidade é um parâmetro que abrange tanto a resistência quanto a ductilidade. Para os materiais dúcteis o módulo de tenacidade pode ser estimado pela equação (75):

$$
\mathrm{U}_{\mathrm{t}} \approx \frac{\mathrm{LE}+\mathrm{LRT}}{2} \varepsilon_{\mathrm{f}}
$$

onde $\varepsilon_{\mathrm{f}}$ corresponde à deformação quando o material sofre a ruptura. Para os materiais frágeis, assume-se que a curva é uma parábola e a área abaixo desta é dada por:

$$
\mathrm{U}_{\mathrm{t}} \approx \frac{2}{3} \mathrm{LRT} \varepsilon_{\mathrm{f}}
$$

O módulo de resiliência corresponde à energia absorvida no campo elástico e corresponde a esta área do gráfico, como mostra a equação:

$$
\mathrm{U}_{\mathrm{r}}=\frac{1}{2} \mathrm{LE} \varepsilon_{\mathrm{e}}=\frac{1}{2} \mathrm{LE} \frac{\mathrm{LE}}{\mathrm{E}}=\frac{\mathrm{LE}^{2}}{2 \mathrm{E}}
$$

onde $\varepsilon_{e}$ corresponde a deformação correspondente ao limite de escoamento.

\subsection{ANÁLI SE ESTATÍ STI CA}

\subsubsection{Regressão e correlação}

O coeficiente de correlação, também denominado coeficiente de Pearson, é uma medida do grau de associação entre duas variáveis. $\mathrm{O}$ grau de associação máximo é igual a 1 quando a associação é diretamente proporcional e quando inversamente proporcional igual a -1 (MATHWORKS, 2008). O valor de R igual a 1 indicaria uma correlação perfeita entre $x$ e $y$. A equação (78) mostra como obter este coeficiente: 


$$
R=\frac{\sum_{i}\left(x_{i}-\bar{x}\right)\left(y_{i}-\bar{y}\right)}{\sqrt{\sum_{i}\left(x_{i}-\bar{x}\right)^{2}} \sqrt{\sum_{i}\left(y_{i}-\bar{y}\right)^{2}}}
$$

A regressão linear consiste na obtenção de uma equação linear capaz de estimar o valor de uma variável através de outra. Esta relação é descrita pela equação:

$$
y=a x+b
$$

onde a corresponde ao coeficiente angular da reta e b ao intercepto-y (ponto de intersecção da reta com a ordenada). A dispersão dos dados é representada pela Figura 36 e é ajustada pela técnica dos mínimos quadrados, onde os valores de $a$ e b são obtidos por:

$$
\begin{gathered}
a=\frac{n \sum x y-\left(\sum x\right)\left(\sum y\right)}{n \sum x^{2}-\left(\sum x\right)^{2}} \\
b=\frac{\sum y}{n}-a \frac{\sum x}{n}
\end{gathered}
$$

Em um ajuste perfeito (isto é, $\mathrm{x}=\mathrm{y}$ ) o coeficiente angular da reta deveria ser 1 e intercepto-y igual a zero.

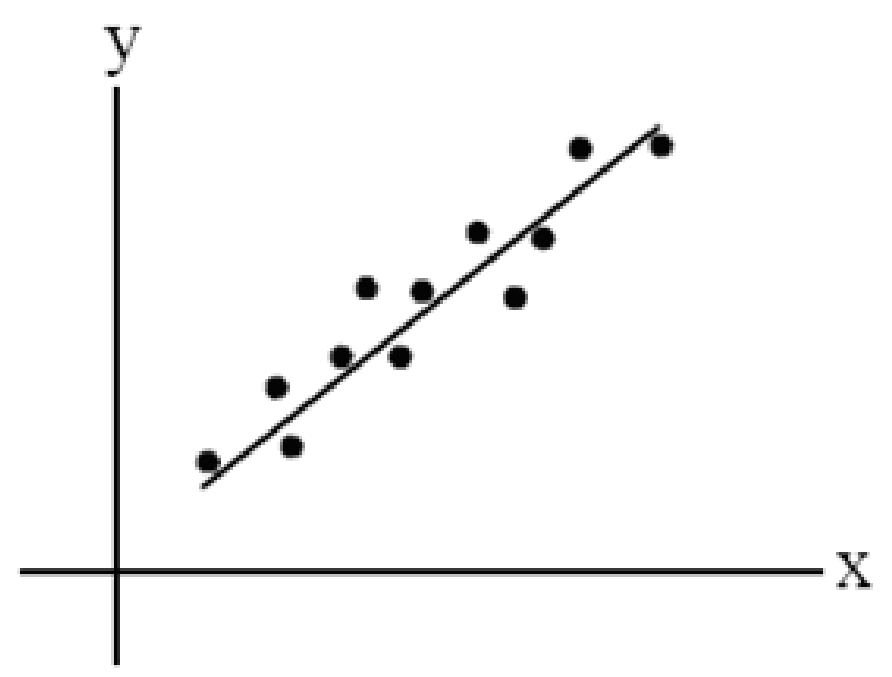

Figura 36: Diagrama de dispersão indicando o melhor ajuste obtido por regressão linear. 


\subsubsection{Análise de variância}

O objetivo da análise de variância, ou ANOVA (sigla em inglês) é comparar a média de duas amostras independentes. Considera-se 0 seguinte teste de hipóteses:

$$
\left\{\begin{array}{l}
\mathrm{H}_{0}: \mu_{1}=\mu_{2} \\
\mathrm{H}_{\mathrm{A}}: \mu_{1} \neq \mu_{2}
\end{array}\right.
$$

Onde se verifica qual a porção da variância total, explicada pela regressão, é estatisticamente significante. A hipótese nula $\left(\mathrm{H}_{0}\right)$ é a de que a média da variável 1 é igual a média da variável 2, portanto ao rejeitar $\mathrm{H}_{0}$ admiti-se que 1 e 2 têm médias diferentes (MONTGOMERY, 1997). $H_{A}$ é denominada hipótese alternativa. As variâncias descritas serão comparadas a:

$$
F=\frac{\frac{\sum_{i=1}^{n}\left(\hat{y}_{i}-\bar{y}\right)^{2}}{v_{\text {grupo }}}}{\frac{\sum_{i=1}^{n}\left(y_{i}-\hat{y}_{i}\right)^{2}}{v_{\text {erro }}}}=\frac{M S_{\text {grupo }}}{M S_{\text {erro }}}
$$

que, sob $H_{0}$, tem distribuição $F$ com graus de liberdade ( $v_{\text {grupo }}$ e $v_{\text {erro }}$ ). Portanto rejeita-se $\mathrm{H}_{\mathrm{A}}$ quando $\mathrm{MS}_{\text {grupo }}$ for significativamente maior que

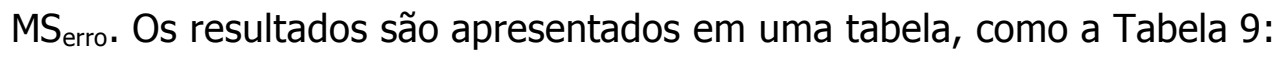

Tabela 9: Resultados do teste da ANOVA

\begin{tabular}{lcccccc}
\hline & & $\begin{array}{c}\text { Graus de } \\
\text { liberdade }\end{array}$ & $\begin{array}{c}\text { Soma dos } \\
\text { quadrados }\end{array}$ & $\begin{array}{c}\text { Quadrados } \\
\text { médios }\end{array}$ & $\mathrm{F}$ & Valor $\mathrm{p}$ \\
\hline $\begin{array}{l}\text { Entre } \\
\text { grupos }\end{array}$ & os & $v_{\text {grupo }}$ & $\mathrm{SS}_{\text {grupo }}$ & $\mathrm{MS}_{\text {grupo }}$ & $\mathrm{MS}_{\text {grupo }} /$ & \\
$\begin{array}{l}\text { Dentro } \\
\text { grupos }\end{array}$ & dos & $v_{\text {erro }}$ & $\mathrm{SS}_{\text {erro }}$ & $\mathrm{MS}_{\text {erro }}$ & & \\
\begin{tabular}{l} 
Total \\
\hline
\end{tabular} & & $v_{\text {grupo }}-v_{\text {erro }}$ & $\mathrm{SS}_{\text {total }}$ & $\mathrm{SS}_{\text {total }}$ & & \\
\hline
\end{tabular}

Quando a amostra for pequena, ou seja, menor que 30, deve-se empregar o teste t-student para calcular o teste de hipóteses. 


$$
\mathrm{t}_{v}=\frac{\overline{\mathrm{x}}_{1}-\overline{\mathrm{x}}_{2}}{\mathrm{~S} \sqrt{\frac{1}{\mathrm{n}_{1}}+\frac{1}{\mathrm{n}_{2}}}}
$$

onde $S$ é o desvio padrão. Os resultados serão apresentados em uma disposição como a da Tabela 10. O critério de rejeição se baseia no valor de $\mathrm{H}$. Quando a $\mathrm{H}=0$ deve-se aceitar a hipótese nula de que as médias são iguais e quando $\mathrm{H}=1$ rejeita-se tal hipótese.

Tabela 10: Resultados do teste de hipóteses da distribuição t.

\begin{tabular}{ccccc}
\hline $\begin{array}{c}\text { Graus de } \\
\text { liberdade }\end{array}$ & $\mathrm{H}$ & $\begin{array}{c}\text { Intervalo de } \\
\text { confiança }\end{array}$ & $\mathrm{t}$ & Confiança \\
\hline
\end{tabular}

Em resumo, o que se espera é encontrar um valor para o coeficiente de correlação e para o coeficiente angular próximo a 1, um valor-p pequeno para o teste de ANOVA ou $\mathrm{H}=0$ para o teste $t$. Se todas estas condições forem satisfeitas o modelo poderá ser validado.

\subsubsection{Análise dos componentes principais}

Em algumas situações, o vetor de entrada da rede neural é grande, no entanto os vetores estão altamente correlacionados (redundantes). Tal situação permite utilizar uma técnica estatística para reduzir o vetor de entrada. Trata-se da análise dos componentes principais. Esta técnica provoca três efeitos: ortogonaliza os componentes do vetor de entrada; ordena os componentes ortogonais (componentes principais) de forma que o que apresentar maior variação apareça primeiro; e elimina aqueles componentes que contribuem menos na variação do conjunto de dados (MATHWORKS, 2008). Esta técnica permite diminuir o número de variáveis de entrada da rede, mas não revela quais os vetores que foram eliminados. 


\section{RESULTADOS E DI SCUSSÃO}

\subsection{RESULTADOS EXPERI MENTAIS}

\subsubsection{Dureza}

Os valores de dureza apresentados refletem a média de 5 medidas efetuadas na superfície plana do corpo de prova de tração, conforme preconiza a literatura. A Tabela 12 traz os valores médios da dureza medida para cada material temperado. As Tabelas 13, 14, 15, 16 e 17 mostram os valores médios para cada condição, para oS aços AISI 4140, AISI 4340, AISI 5160, AISI 6150 e AISI E52100, respectivamente. Para todos os aços observa-se uma tendência de decréscimo da dureza com o aumento do tempo e da temperatura de revenimento.

Tabela 11: Dureza média do material temperado.

\begin{tabular}{cc}
\hline Aço & Dureza [HV] \\
\hline AISI 4140 & 668,7 \\
AISI 4340 & 609,5 \\
AISI 5160 & 733,0 \\
AISI 6150 & 772,0 \\
AISI E52100 & 777,0 \\
\hline
\end{tabular}

Tabela 12: Dureza medida para o aço AISI 4140.

\begin{tabular}{|c|c|c|c|c|c|c|c|c|c|}
\hline \multirow{2}{*}{ Tempo [s] } & \multicolumn{9}{|c|}{ Dureza [HV] } \\
\hline & $100^{\circ} \mathrm{C}$ & $150^{\circ} \mathrm{C}$ & $200^{\circ} \mathrm{C}$ & $250^{\circ} \mathrm{C}$ & $300^{\circ} \mathrm{C}$ & $400^{\circ} \mathrm{C}$ & $500^{\circ} \mathrm{C}$ & $600^{\circ} \mathrm{C}$ & $700^{\circ} \mathrm{C}$ \\
\hline 10 & 683,2 & 701,6 & 661,4 & 627,0 & 617,5 & 604,0 & 508,5 & 459,3 & 426,3 \\
\hline 90 & 667,7 & 665,0 & 655,1 & 636,0 & $*$ & 587,8 & * & $*$ & * \\
\hline 900 & 676,3 & 619,0 & 651,0 & 577,0 & 522,6 & 519,0 & * & * & * \\
\hline 3600 & * & * & * & 528,0 & 502,5 & 430,8 & 374,0 & 327,9 & 242,0 \\
\hline 9000 & 662,0 & 556,8 & 548,2 & 514,5 & 487,7 & 425,2 & 362,1 & 301,2 & 234,0 \\
\hline 86400 & 661,4 & 535,0 & 520,0 & 510,0 & 442,4 & 401,0 & $*$ & 287,6 & 216,0 \\
\hline
\end{tabular}


Tabela 13: Dureza medida para o aço AISI 4340.

\begin{tabular}{|c|c|c|c|c|c|c|c|c|c|}
\hline \multirow{2}{*}{ Tempo [s] } & \multicolumn{9}{|c|}{ Dureza [HV] } \\
\hline & $100 \div \mathrm{C}$ & $150^{\circ} \mathrm{C}$ & $200 \div \mathrm{C}$ & $250^{\circ} \mathrm{C}$ & $300^{\circ} \mathrm{C}$ & $400^{\circ} \mathrm{C}$ & $500^{\circ} \mathrm{C}$ & $600^{\circ} \mathrm{C}$ & $700^{\circ} \mathrm{C}$ \\
\hline 10 & 631,0 & 602,2 & 609,4 & 593,2 & 575,3 & 584,2 & 449,9 & 436,4 & 344,0 \\
\hline 90 & 611,0 & 598,6 & 602,2 & 586,0 & 514,8 & 486,8 & 447,2 & 367,7 & 331,0 \\
\hline 900 & 602,2 & 615,0 & 598,6 & 557,8 & 511,2 & 460,1 & 372,0 & 330,6 & 327,0 \\
\hline 3600 & * & * & * & 521,5 & 488,2 & 433,4 & 365,7 & 316,4 & 239,0 \\
\hline 9000 & 600,4 & 547,2 & 522,6 & 479,1 & 455,6 & 404,1 & 350,4 & 255,6 & 216,0 \\
\hline 86400 & 593,2 & 529,6 & 466,2 & 448,2 & 437,8 & 361,7 & 341,0 & 244,5 & 205,0 \\
\hline
\end{tabular}

*Condições não ensaiadas

Tabela 14: Dureza medida para o aço AISI 5160.

\begin{tabular}{cccccccccc}
\hline \multirow{2}{*}{ Tempo [s] } & \multicolumn{7}{c}{ Dureza [HV] } \\
\cline { 2 - 10 } & $100 \circ \mathrm{C}$ & $150 \circ \mathrm{C}$ & $200 \circ \mathrm{C}$ & $250 \mathrm{O}$ & $300 \circ \mathrm{C}$ & $400 \circ \mathrm{C}$ & $500 \circ \mathrm{C}$ & $600 \circ \mathrm{C}$ & $700 \circ \mathrm{C}$ \\
\hline 10 & 703,9 & 706,2 & 699,3 & 701,6 & 667,7 & 649,0 & 582,0 & 553,6 & 407,0 \\
90 & 694,7 & 692,4 & 692,4 & 697,0 & 665,6 & 570,2 & 499,5 & 465,8 & 331,0 \\
900 & 699,3 & 680,9 & 674,0 & 641,0 & 563,7 & 455,6 & 397,0 & 413,1 & 278,3 \\
3600 & $*$ & $*$ & $*$ & 548,8 & 514,0 & 432,1 & 345,9 & 285,1 & 234,0 \\
9000 & 674,0 & 659,3 & 598,6 & 544,0 & 436,4 & 390,0 & 332,4 & 259,6 & 228,0 \\
86400 & 651,0 & 620,0 & 540,8 & 460,2 & 431,1 & 386,8 & 266,6 & 242,0 & 185,0 \\
\hline
\end{tabular}

${ }^{*}$ Condições não ensaiadas

Tabela 15: Dureza medida para o aço AISI 6150.

\begin{tabular}{cccccccccc}
\hline \multirow{2}{*}{ Tempo [s] } & \multicolumn{8}{c}{ Dureza [HV] } \\
\cline { 2 - 10 } & $100^{\circ} \mathrm{C}$ & $150^{\circ} \mathrm{C}$ & $200 \circ \mathrm{C}$ & $250^{\circ} \mathrm{C}$ & $300^{\circ} \mathrm{C}$ & $400^{\circ} \mathrm{C}$ & $500^{\circ} \mathrm{C}$ & $600^{\circ} \mathrm{C}$ & $700^{\circ} \mathrm{C}$ \\
\hline 10 & 791,6 & 777,6 & 746,0 & 772,0 & 703,9 & 667,7 & 623,0 & 505,5 & 425,2 \\
90 & 769,4 & 774,8 & 713,1 & 706,2 & 671,9 & 623,0 & 492,4 & 438,8 & 366,6 \\
900 & 783,2 & 797,2 & 694,0 & 637,0 & 563,7 & 508,5 & 438,0 & 367,7 & 352,2 \\
3600 & $*$ & $*$ & $*$ & 565,1 & 522,0 & 476,2 & 391,0 & 327,0 & 250,4 \\
9000 & 761,6 & 639,2 & 622,6 & 539,2 & 505,3 & 436,9 & 371,1 & 311,9 & 228,0 \\
86400 & 706,2 & 607,6 & 585,4 & 518,7 & 500,5 & 386,8 & 361,2 & 278,0 & 190,0 \\
\hline
\end{tabular}

${ }^{*}$ Condições não ensaiadas

Tabela 16: Dureza medida para o aço AISI E52100.

\begin{tabular}{cccccccccc}
\hline \multirow{2}{*}{ Tempo [s] } & \multicolumn{10}{c}{ Dureza [HV] } \\
\cline { 2 - 10 } & $100^{\circ} \mathrm{C}$ & $1500^{\circ} \mathrm{C}$ & $200^{\circ} \mathrm{C}$ & $250^{\circ} \mathrm{C}$ & $300^{\circ} \mathrm{C}$ & $400^{\circ} \mathrm{C}$ & $500^{\circ} \mathrm{C}$ & $6000^{\circ} \mathrm{C}$ & $700^{\circ} \mathrm{C}$ \\
\hline 10 & 773,4 & 767,0 & 777,6 & 764,0 & 761,0 & 692,0 & 647,8 & 587,8 & 368,0 \\
90 & 777,0 & 762,0 & 753,0 & 759,0 & 738,0 & 671,9 & 561,7 & 540,0 & 343,0 \\
900 & 772,0 & 778,0 & 745,5 & 659,0 & 641,0 & 555,0 & 550,0 & 476,0 & 325,9 \\
3600 & $*$ & $*$ & $*$ & 635,0 & 599,0 & 522,0 & 458,0 & 359,0 & 263,7 \\
9000 & 764,0 & 690,1 & 660,3 & 628,0 & 573,0 & 513,0 & 395,6 & 318,3 & 250,0 \\
86400 & 690,1 & 681,0 & 620,8 & 596,5 & 558,9 & 448,0 & 367,5 & 273,1 & 180,0 \\
\hline
\end{tabular}




\subsubsection{Teste de tração}

O limite de resistência à tração pode ser observado nas Figuras 37, 38, 39, 40 e 41, para os aços AISI 4140, 4340, 5160, 6150 e E52100 respectivamente. Através destes dados é possível observar que o limite de resistência à tração diminui com a temperatura e com o tempo de revenimento. É importante ressaltar que todos os resultados apresentados nesta seção correspondem ao valor médio de cada propriedade obtida para os 3 corpos de prova testados, conforme estabelece a norma ASTM E8M - 04.

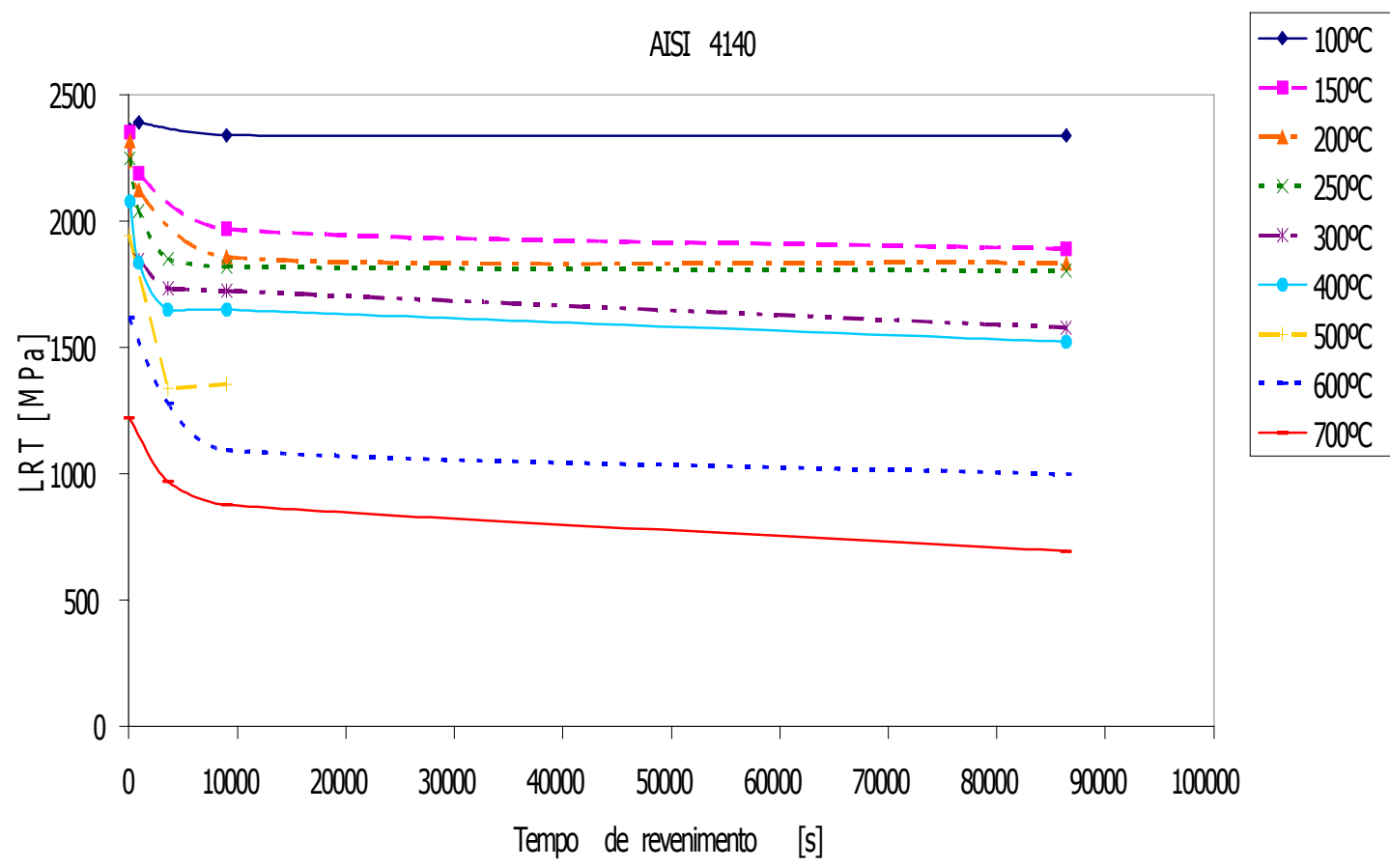

Figura 37: LRT obtidos para o aço AISI 4140 revenido em diversas condições. 


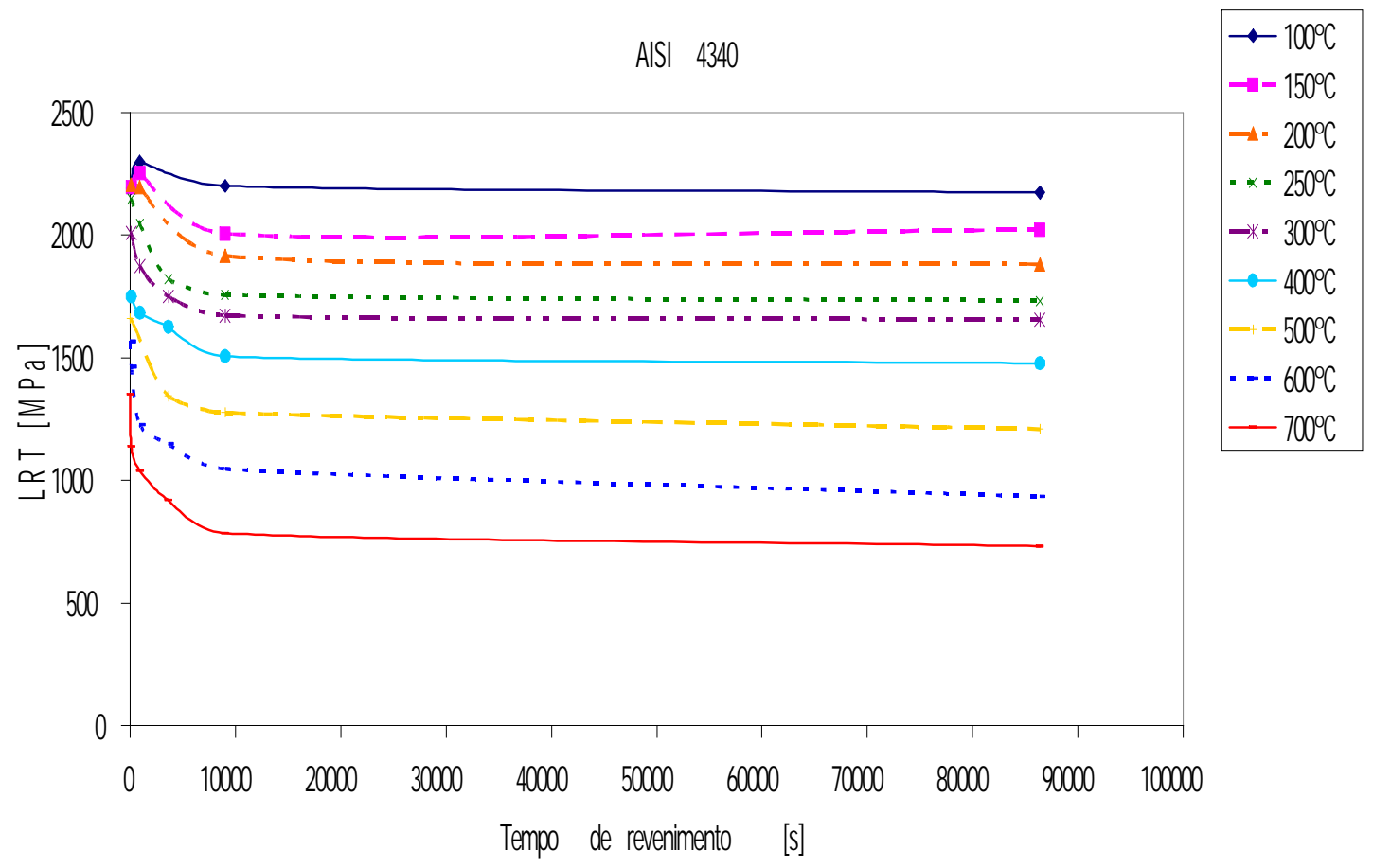

Figura 38: LRT obtidos para o aço AISI 4340 revenido em diversas condições.

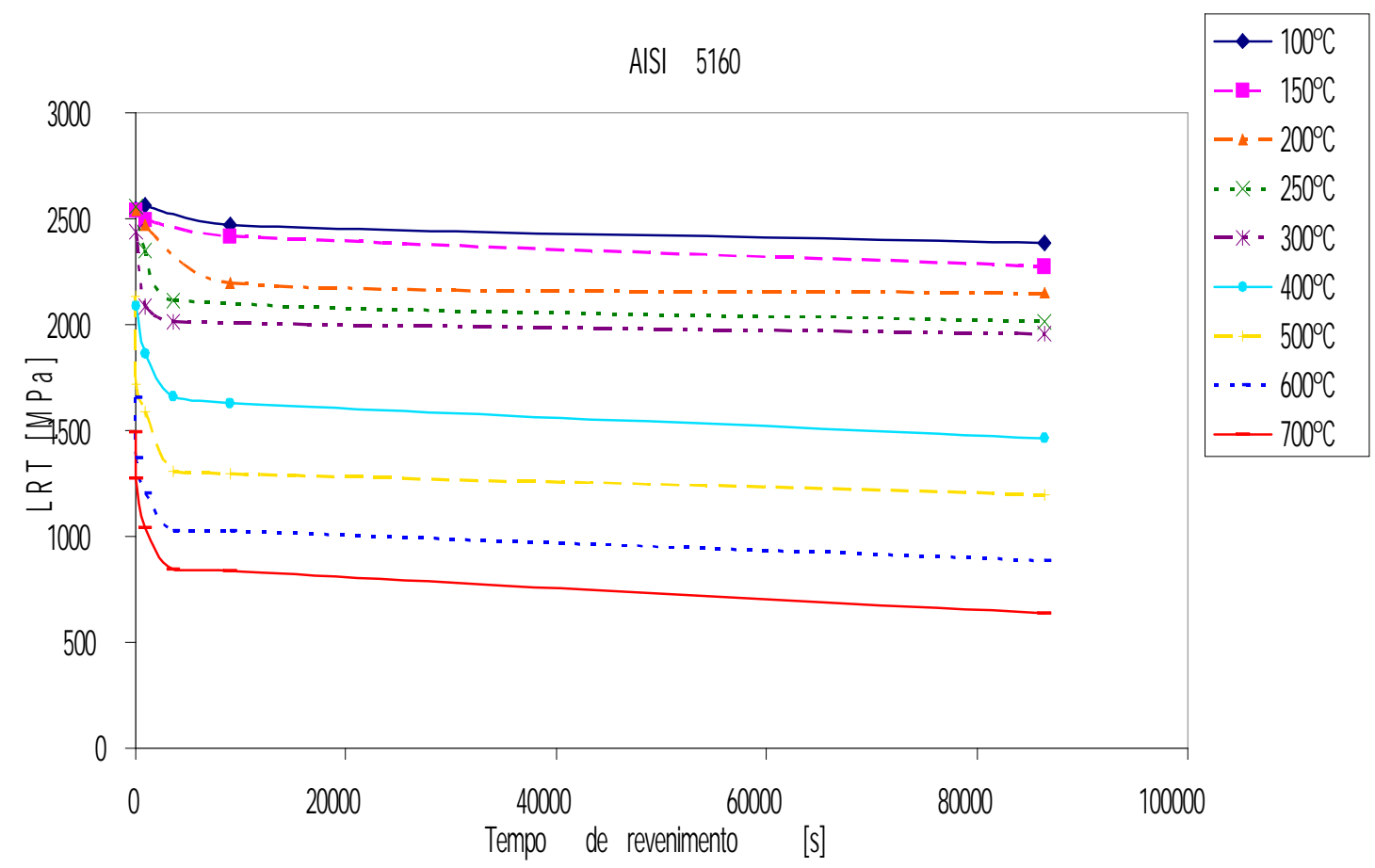

Figura 39: LRT obtidos para o aço AISI 5160 revenido em diversas condições. 


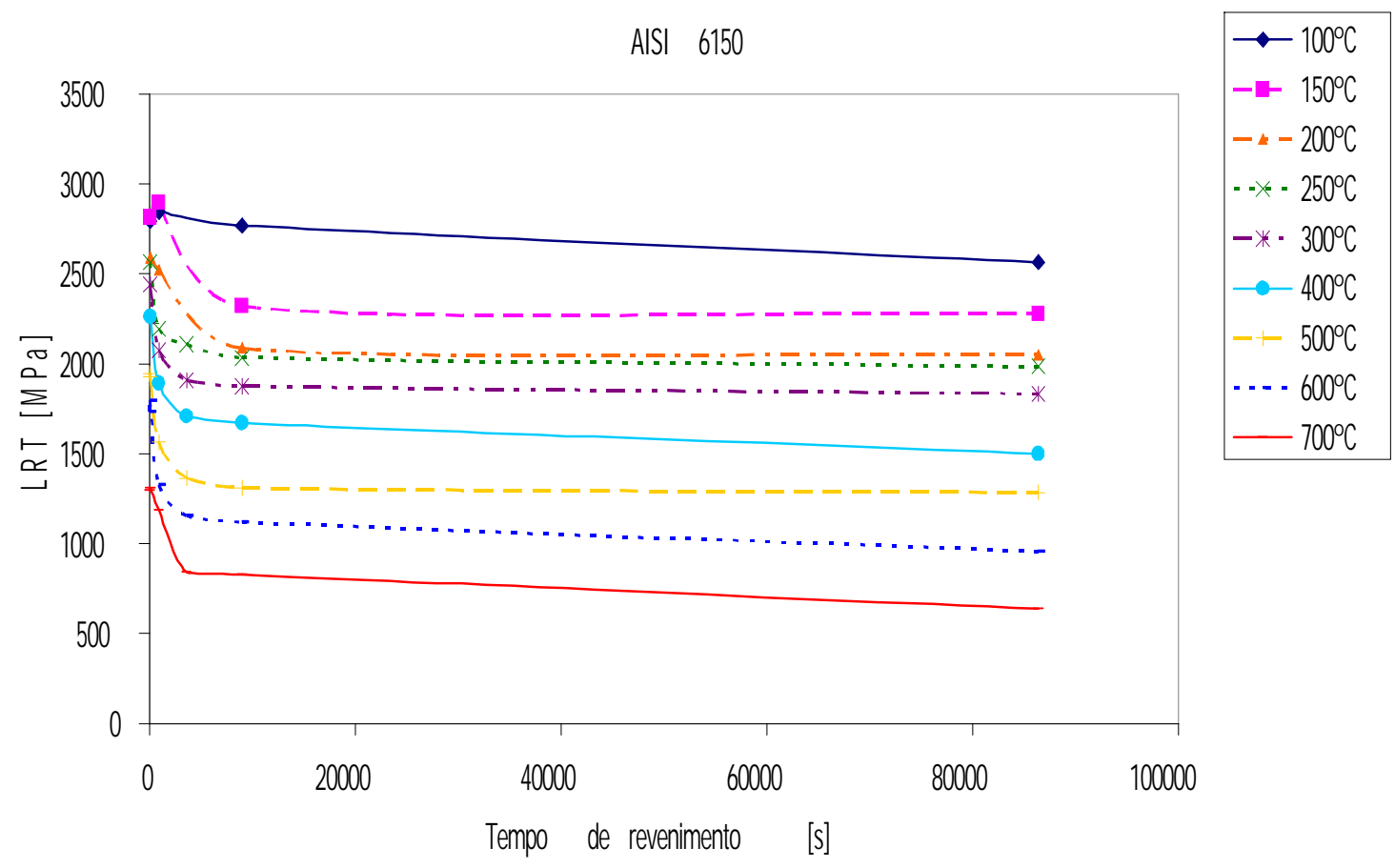

Figura 40: LRT obtidos para o aço AISI 6150 revenido em diversas condições.

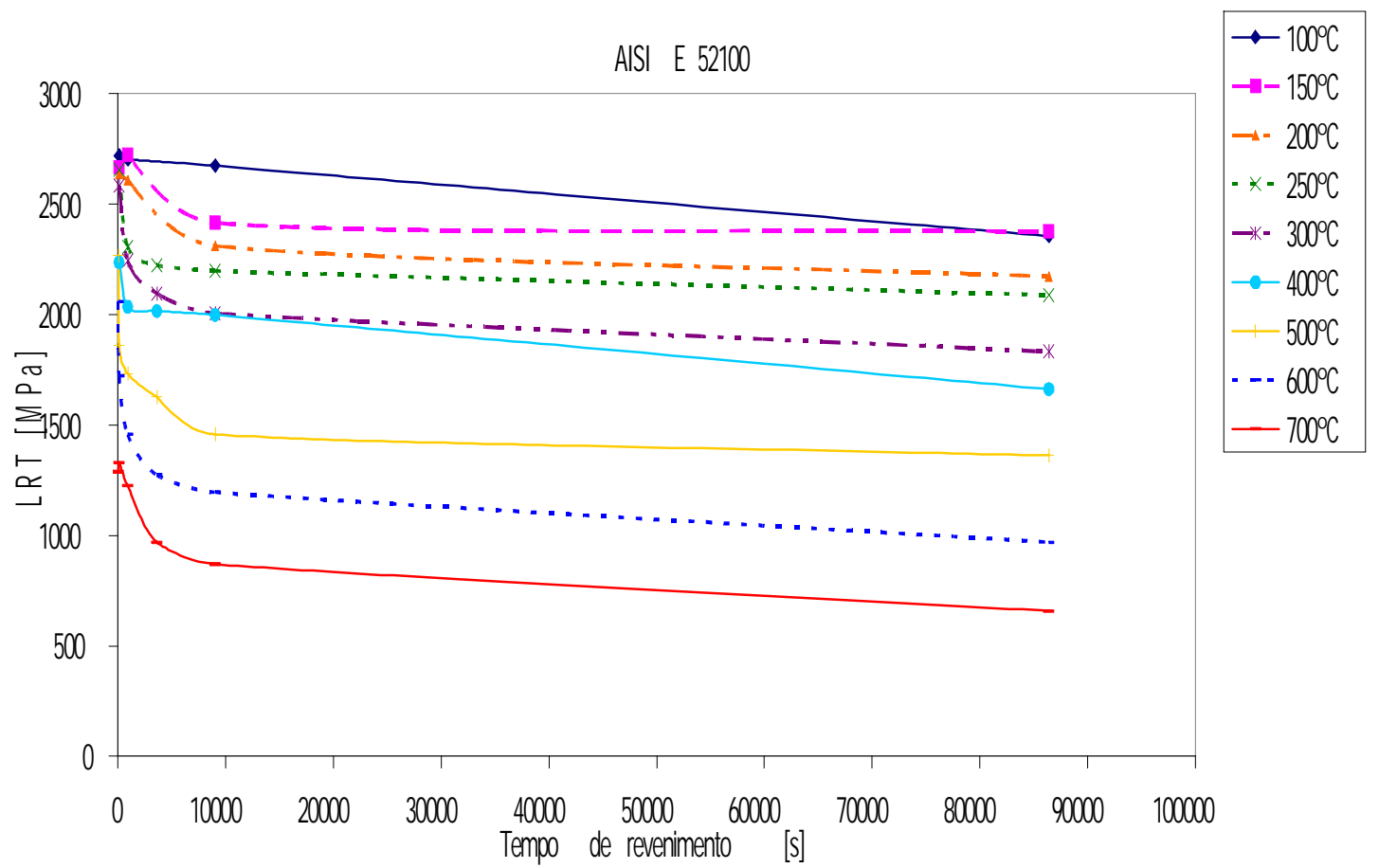

Figura 41: LRT obtidos para o aço AISI E52100 revenido em diversas condições. 
As Figuras 42, 43, 44, 45 e 46 trazem os valores da tensão de ruptura levantados a partir das curvas tensão-deformação de cada condição testada.

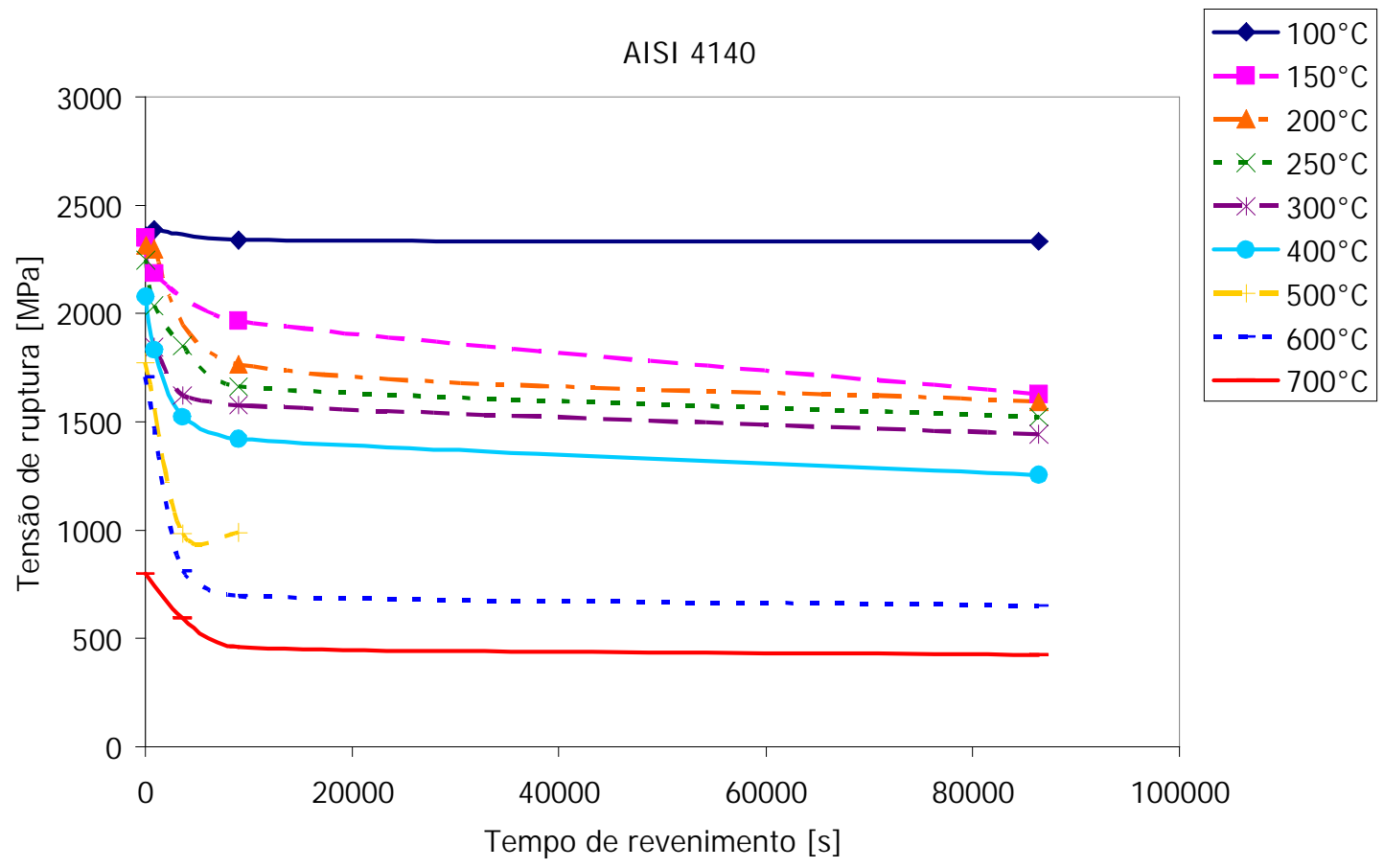

Figura 42: Tensão de ruptura obtida para o aço AISI 4140.

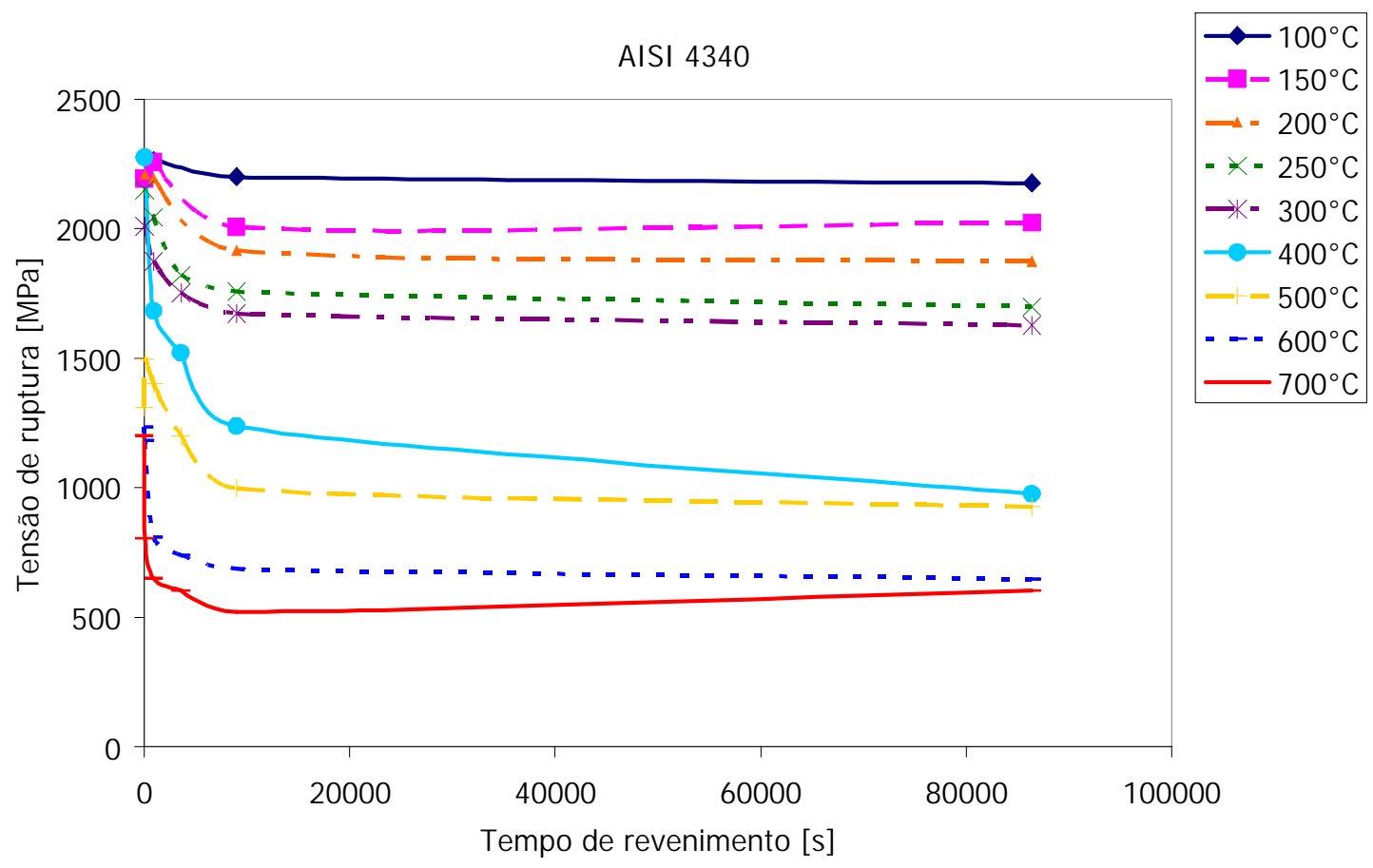

Figura 43: Tensão de ruptura obtida para o aço AISI 4340. 


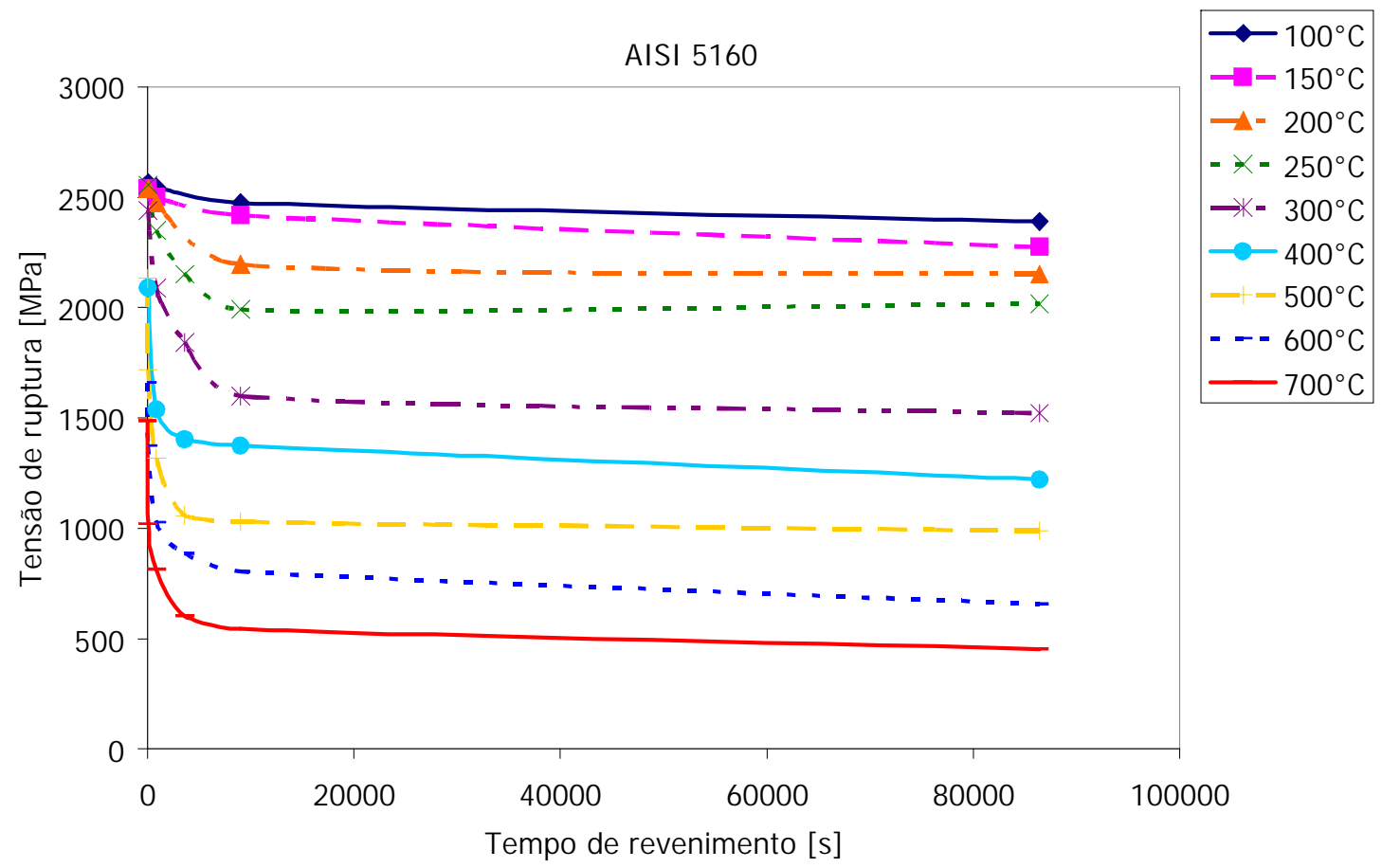

Figura 44: Tensão de ruptura obtida para o aço AISI 5160.

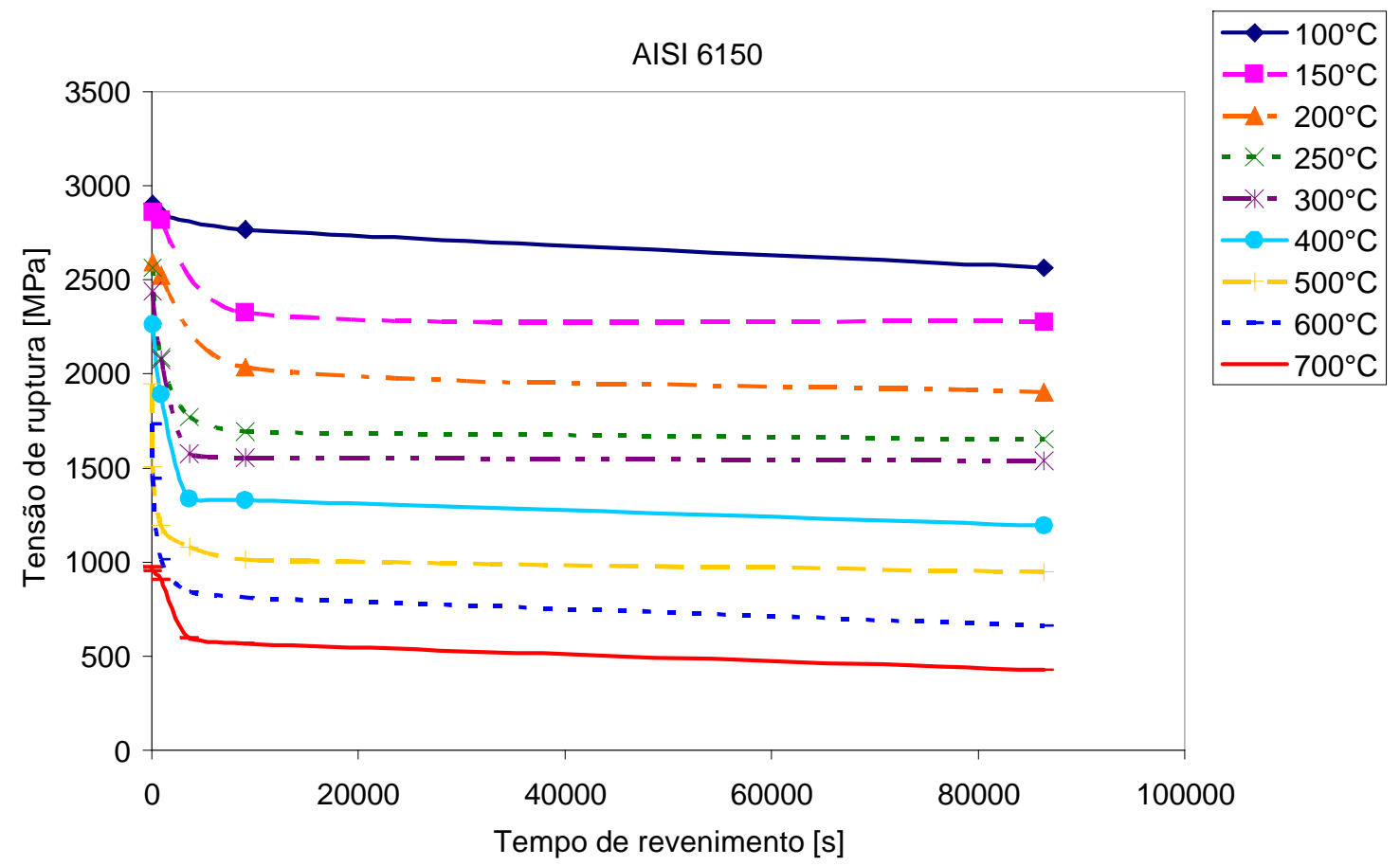

Figura 45: Tensão de ruptura obtida para o aço AISI 6150. 


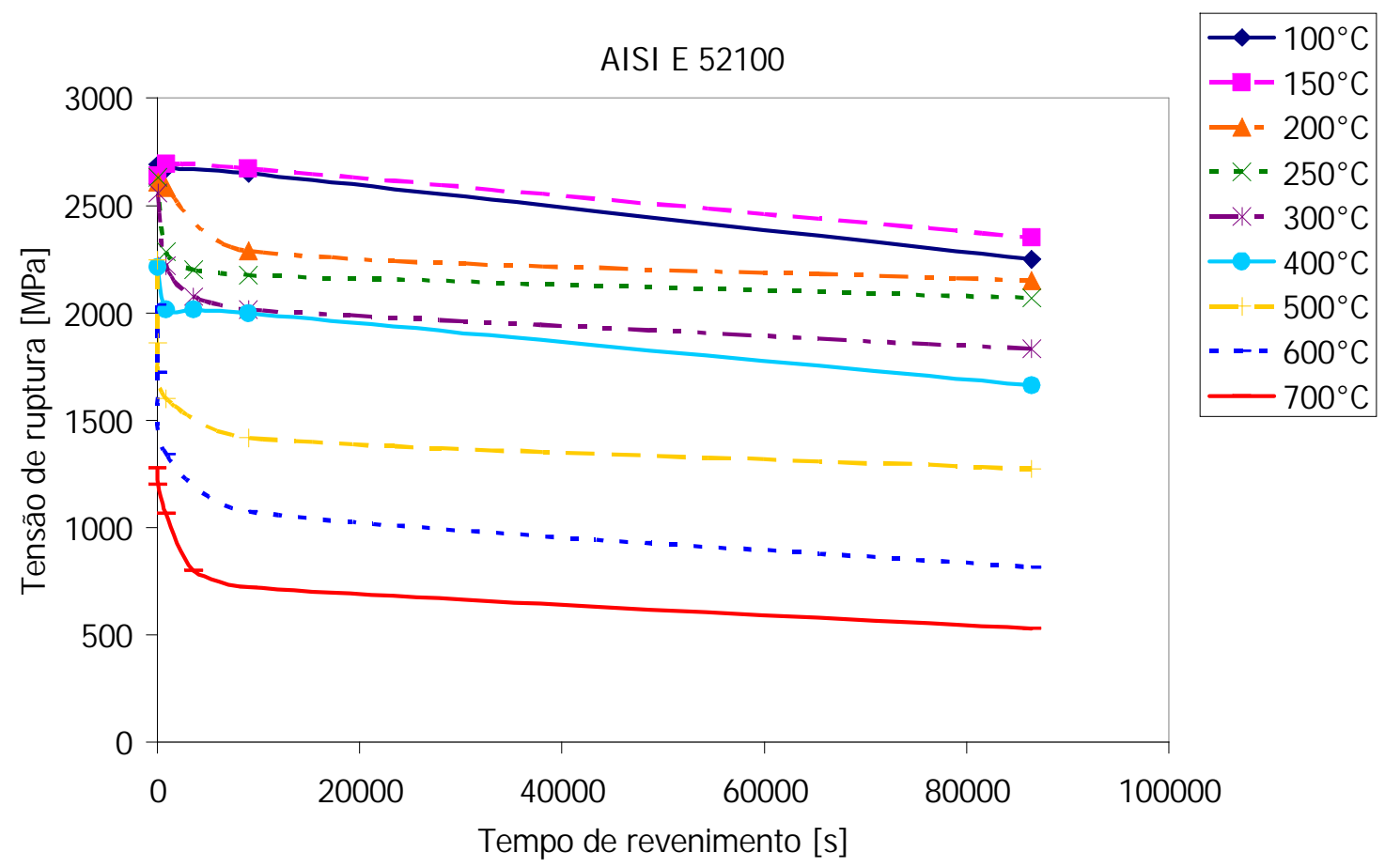

Figura 46: Tensão de ruptura obtida para o aço AISI E52100.

O limite de escoamento é a tensão máxima que o material suporta ainda no regime elástico de deformação, onde o material ainda obedece à lei de Hooke. As Figuras 47, 48, 49, 50 e 51 mostram os valores levantados para os aços AISI 4140, AISI 4340, AISI 5160, AISI 6150 e AISI E52100 respectivamente. De forma análoga ao limite de resistência à tração, o limite de escoamento também decresce com 0 aumento da temperatura e do tempo de revenimento. Este resultado está de acordo com o que preconiza a literatura. Na Figura 52 é possível notar que os aços revenidos a 100 e $150^{\circ} \mathrm{C}$ têm valores muito similares para o LE, isto pode ser explicado pelo fato de que os aços de alto carbono tendem a apresentar uma resistência maior se revenidos a $150^{\circ} \mathrm{C}$. 


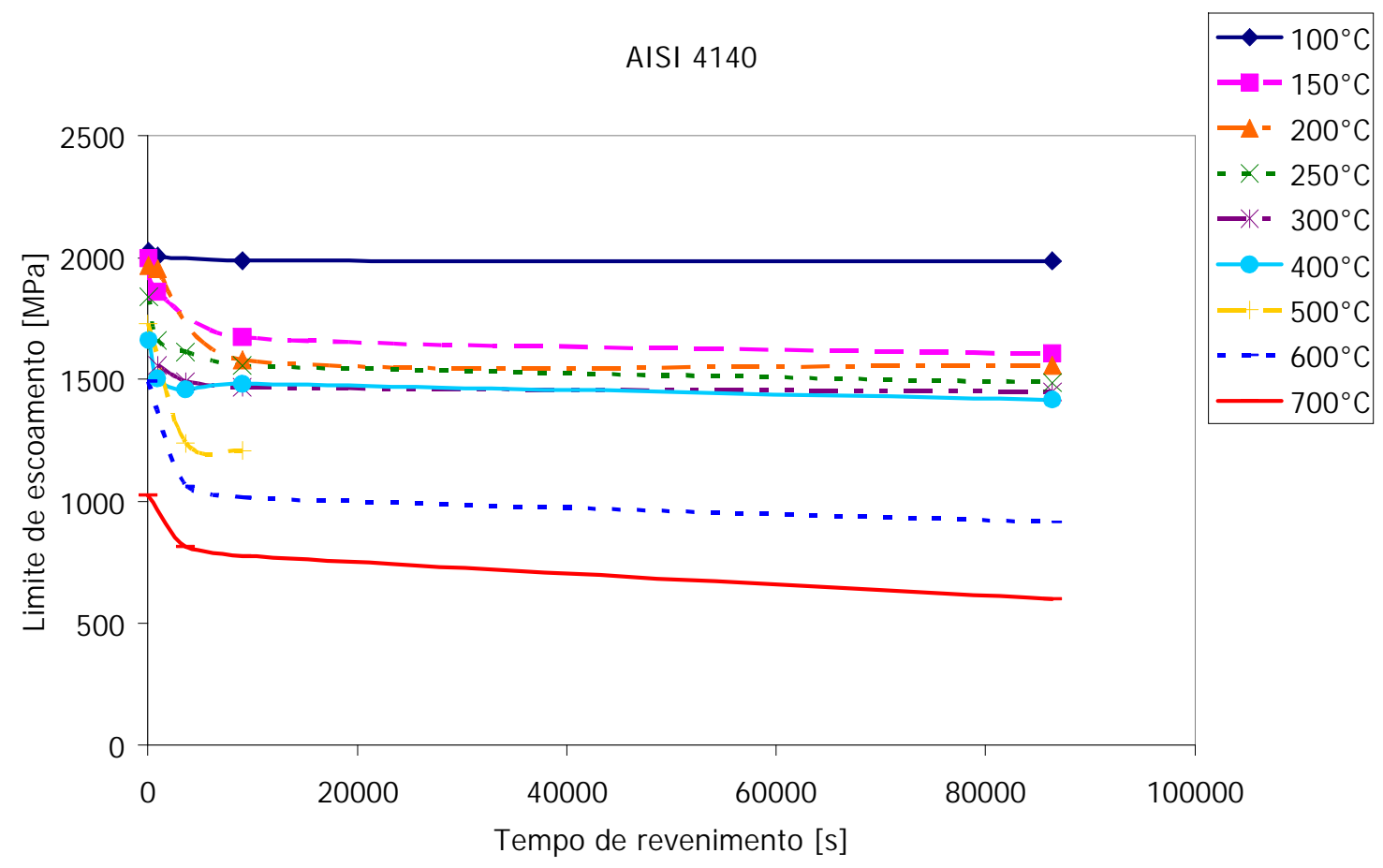

Figura 47: Limite de escoamento obtido para o aço AISI 4140.

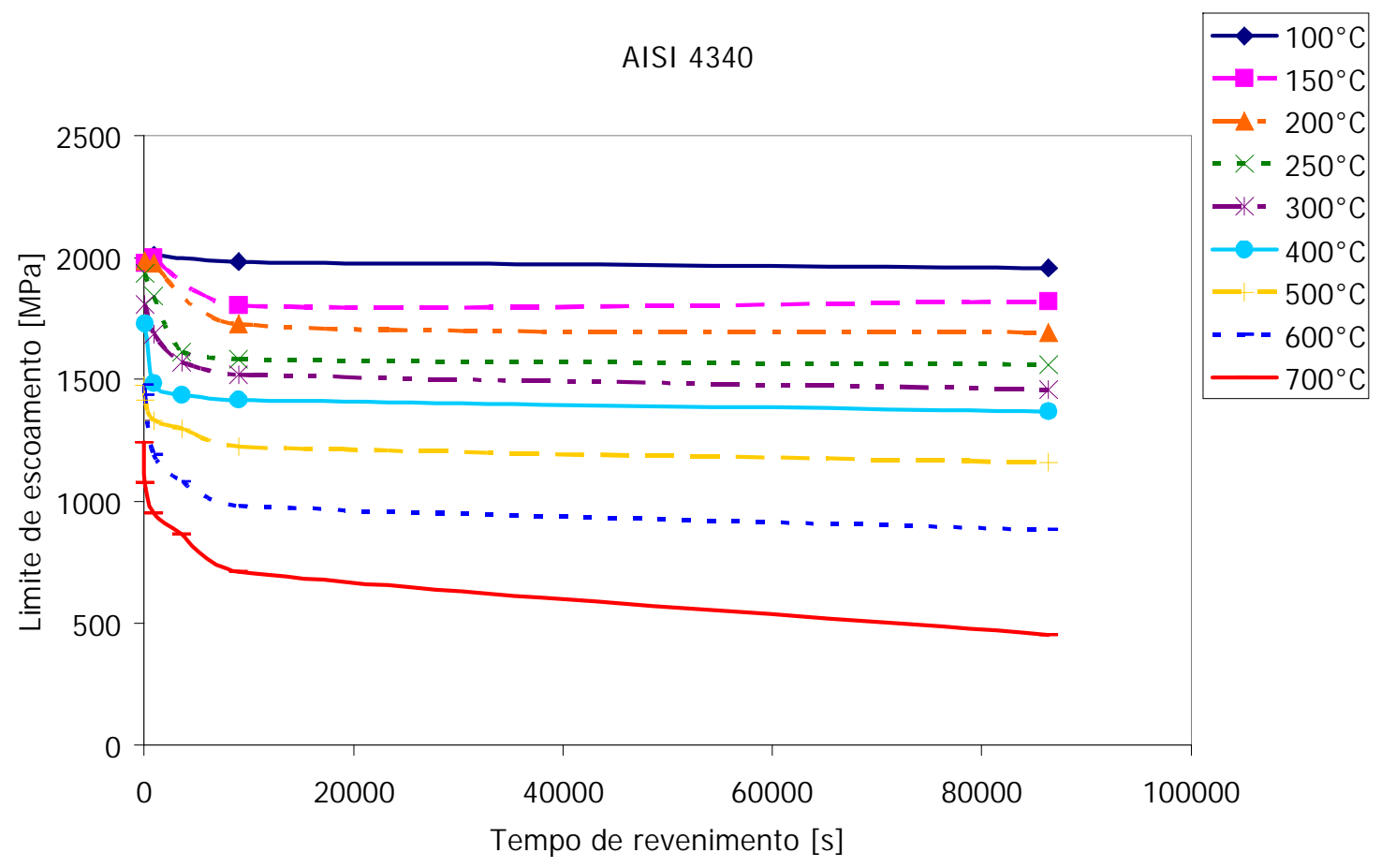

Figura 48: Limite de escoamento obtido para o aço AISI 4340. 


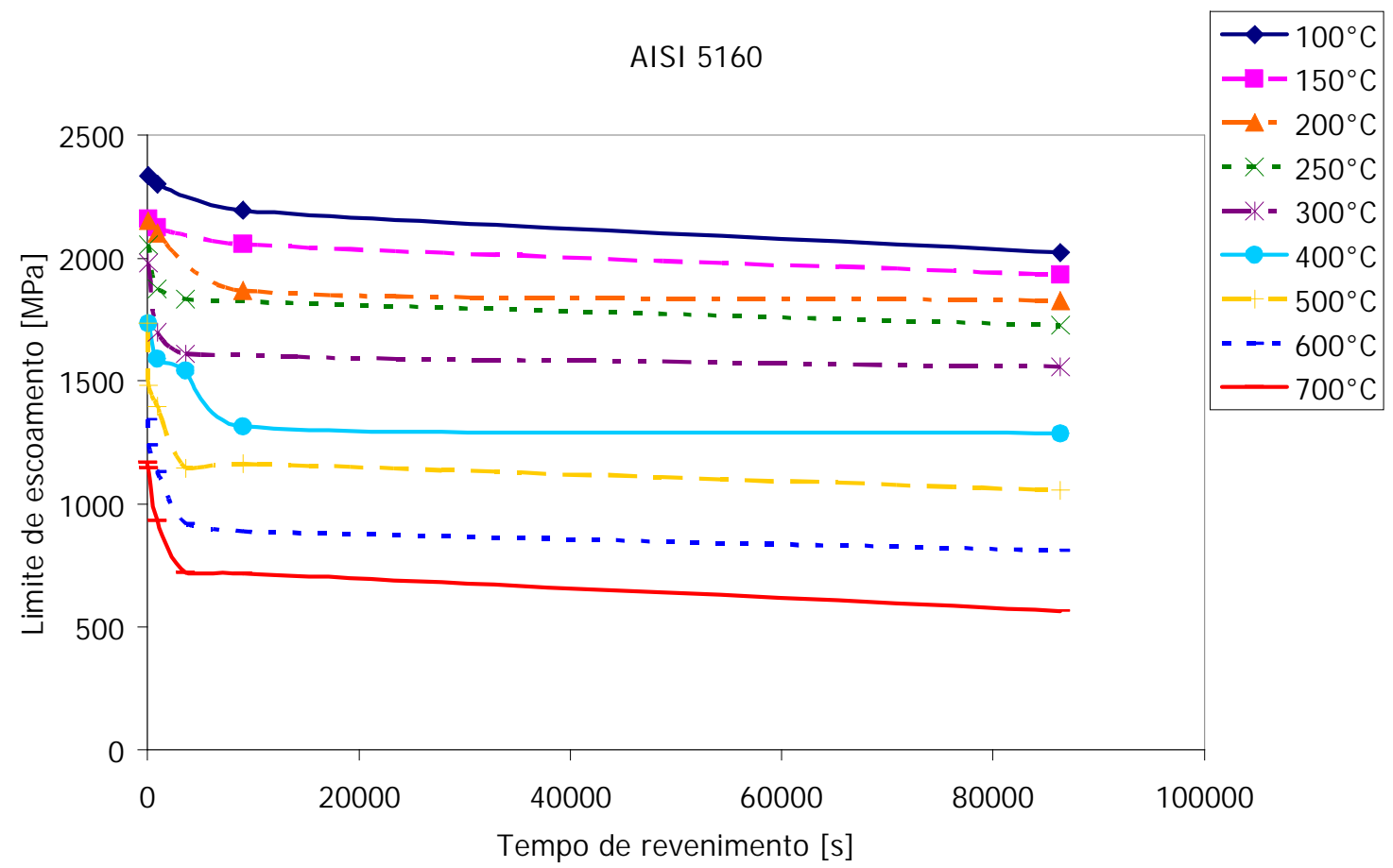

Figura 49: Limite de escoamento obtido para o aço AISI 5160.

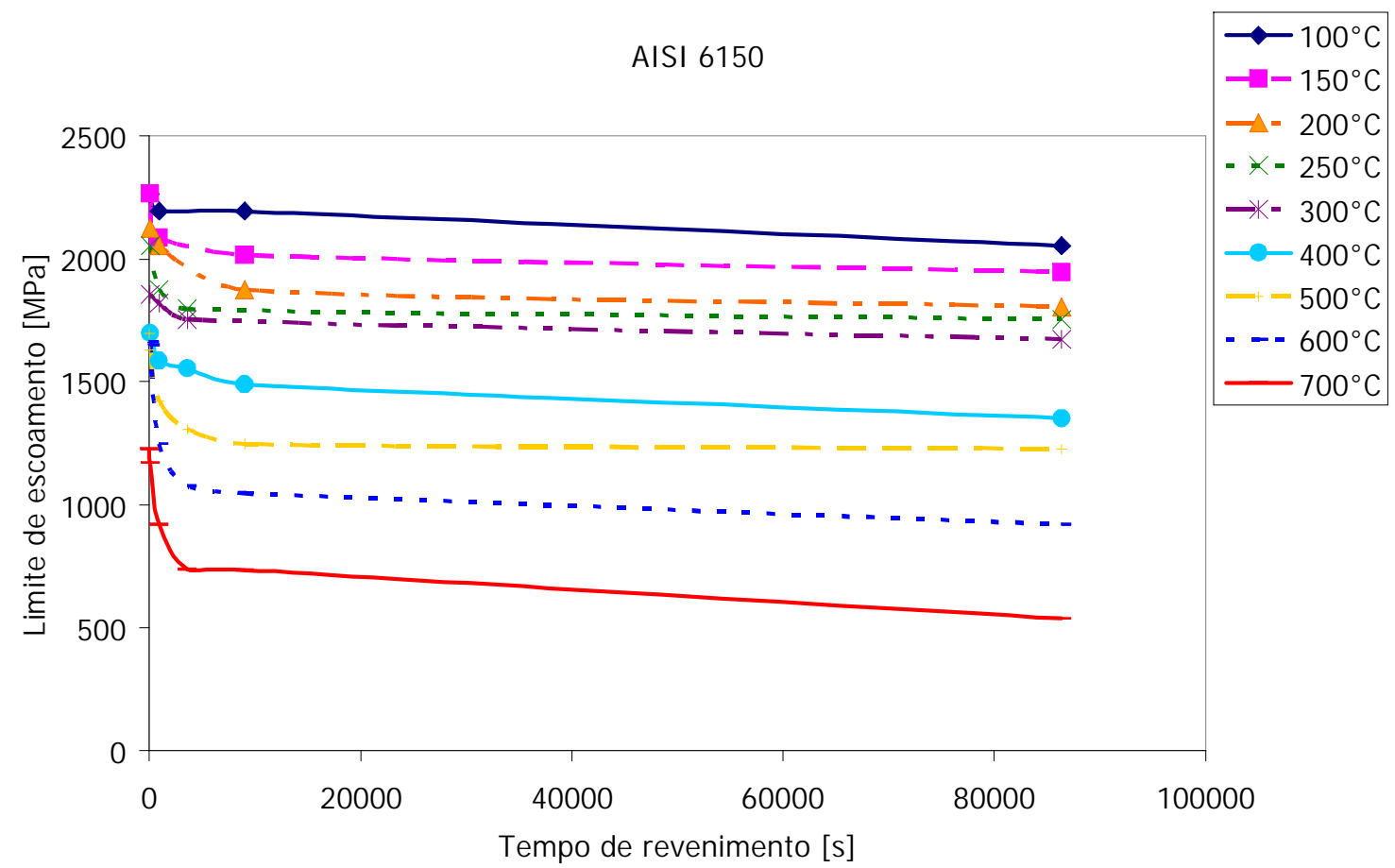

Figura 50: Limite de escoamento obtido para o aço AISI 6150. 


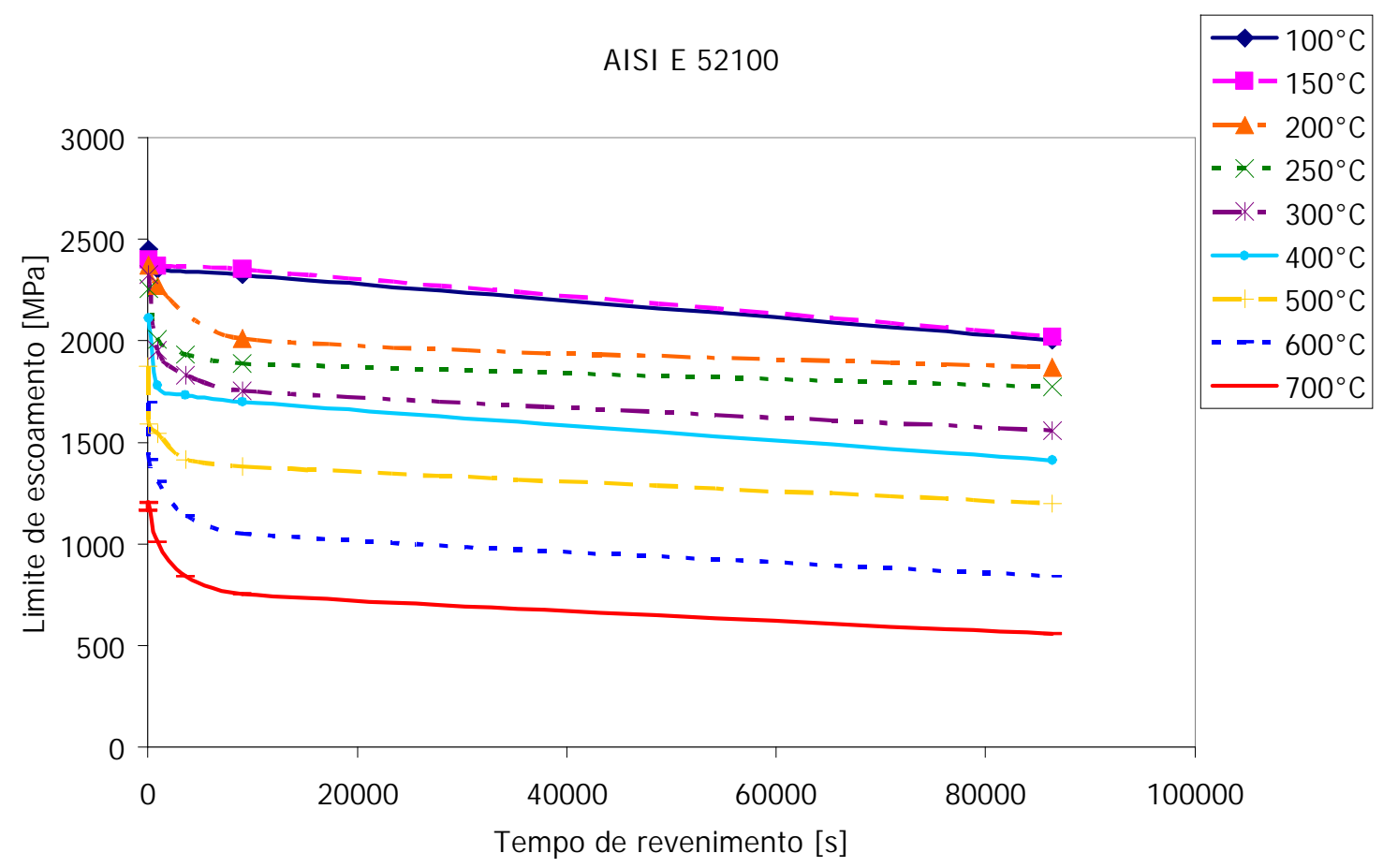

Figura 51: Limite de escoamento obtido para o aço AISI E52100.

0 módulo de resiliência foi calculado pela equação (77) e pode ser observado nas Figuras 52, 53, 54, 55 e 56. É possível observar que seu valor diminui com 0 aumento do tempo e da temperatura de revenimento. Tal resultado era esperado, pois a resiliência mede a habilidade do material em absorver energia quando deformado elasticamente e retornar à forma original quando descarregado e os corpos de prova revenidos nas temperaturas inferiores também exibem maior valor para o limite de escoamento. 


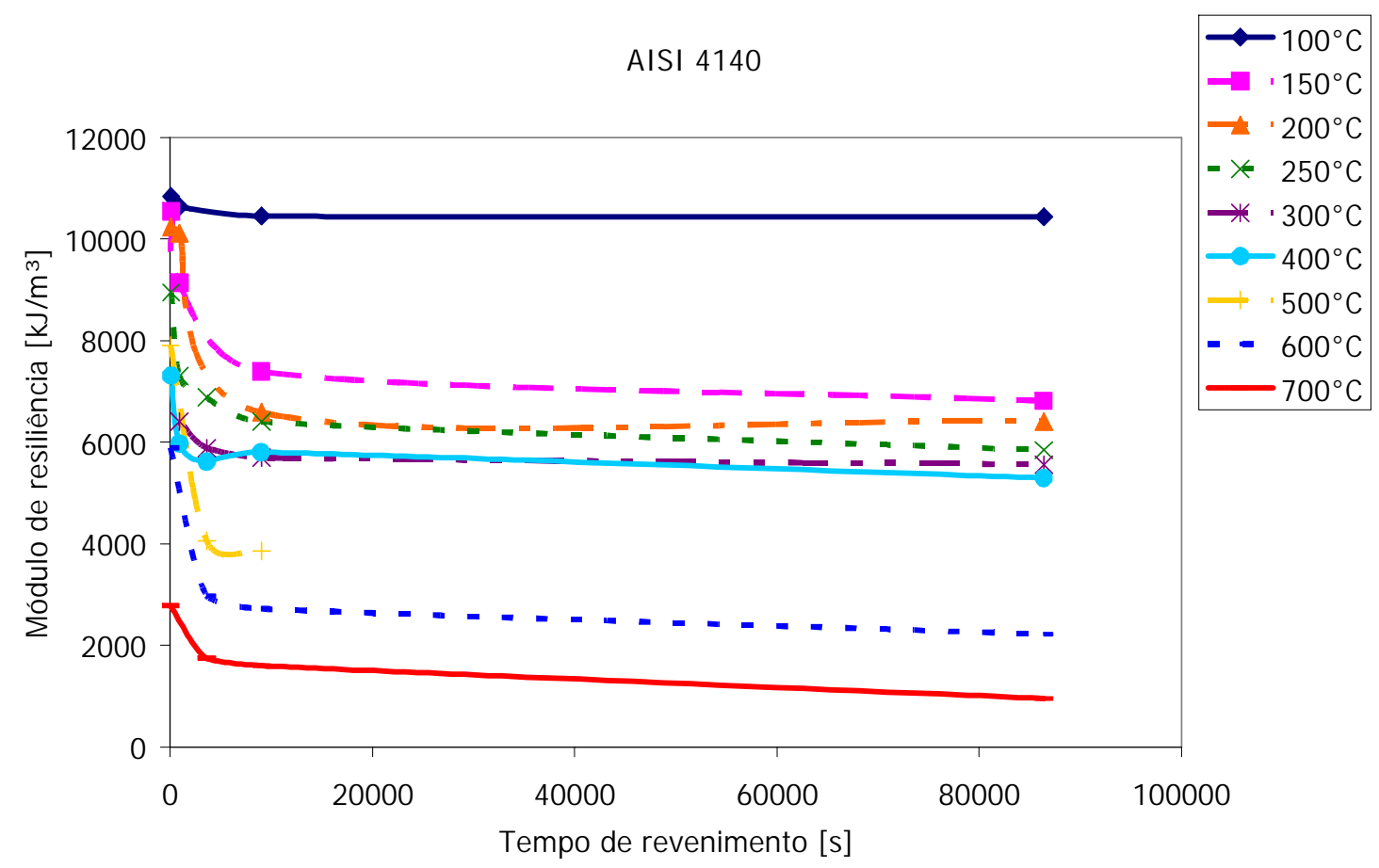

Figura 52: Módulo de resiliência obtido para o aço AISI 4140.

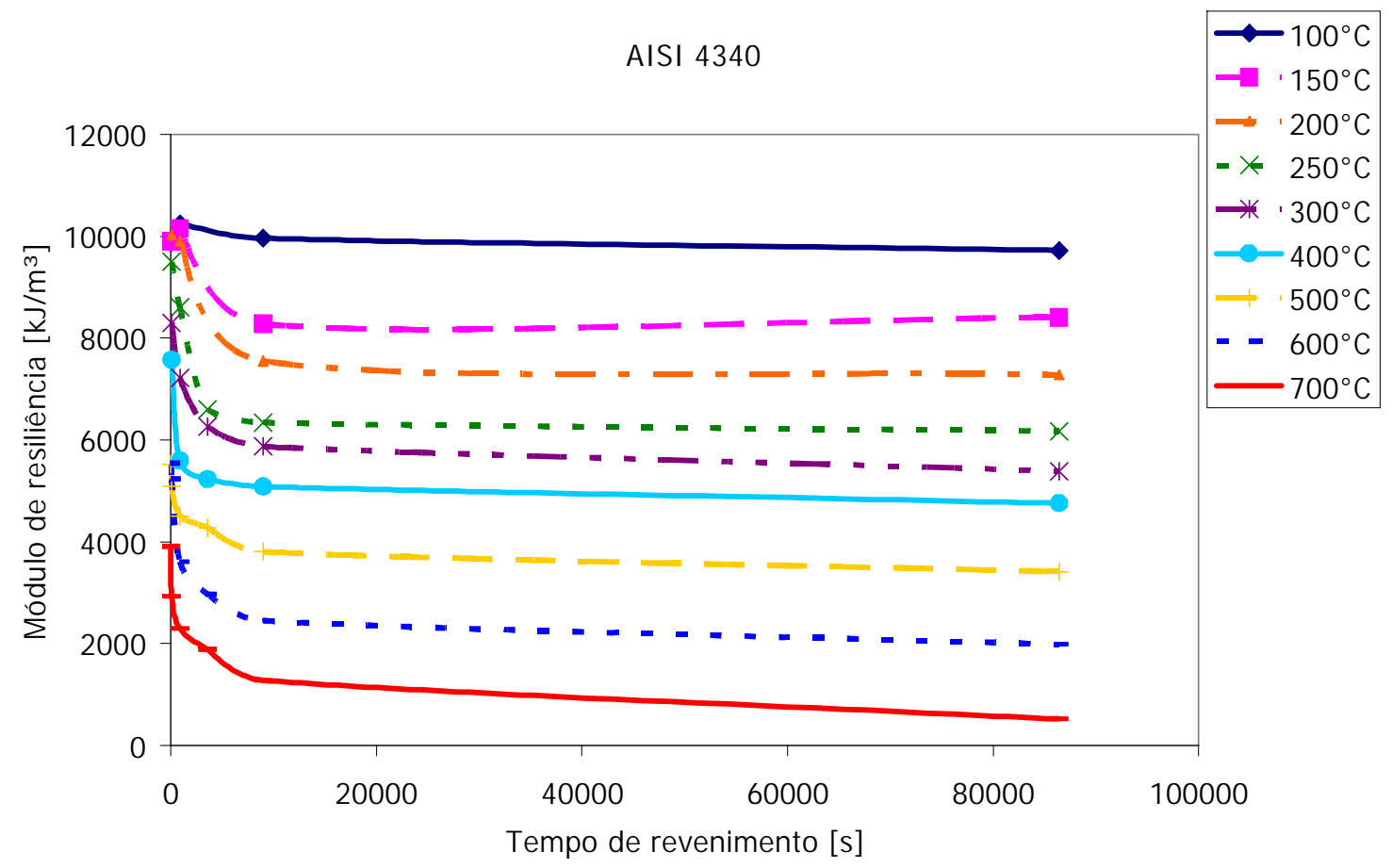

Figura 53: Módulo de resiliência obtido para o aço AISI 4340. 


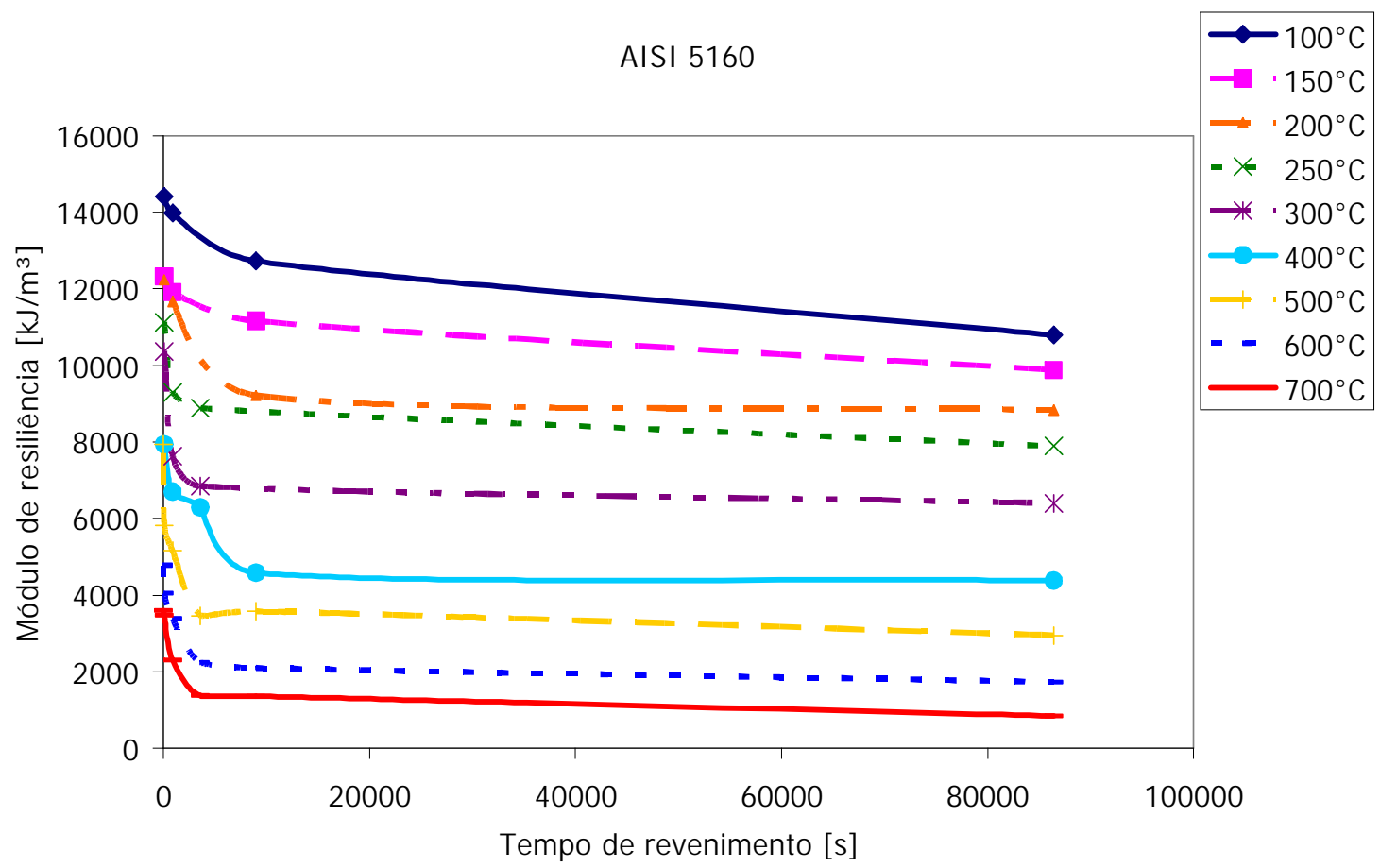

Figura 54: Módulo de resiliência obtido para o aço AISI 5160.

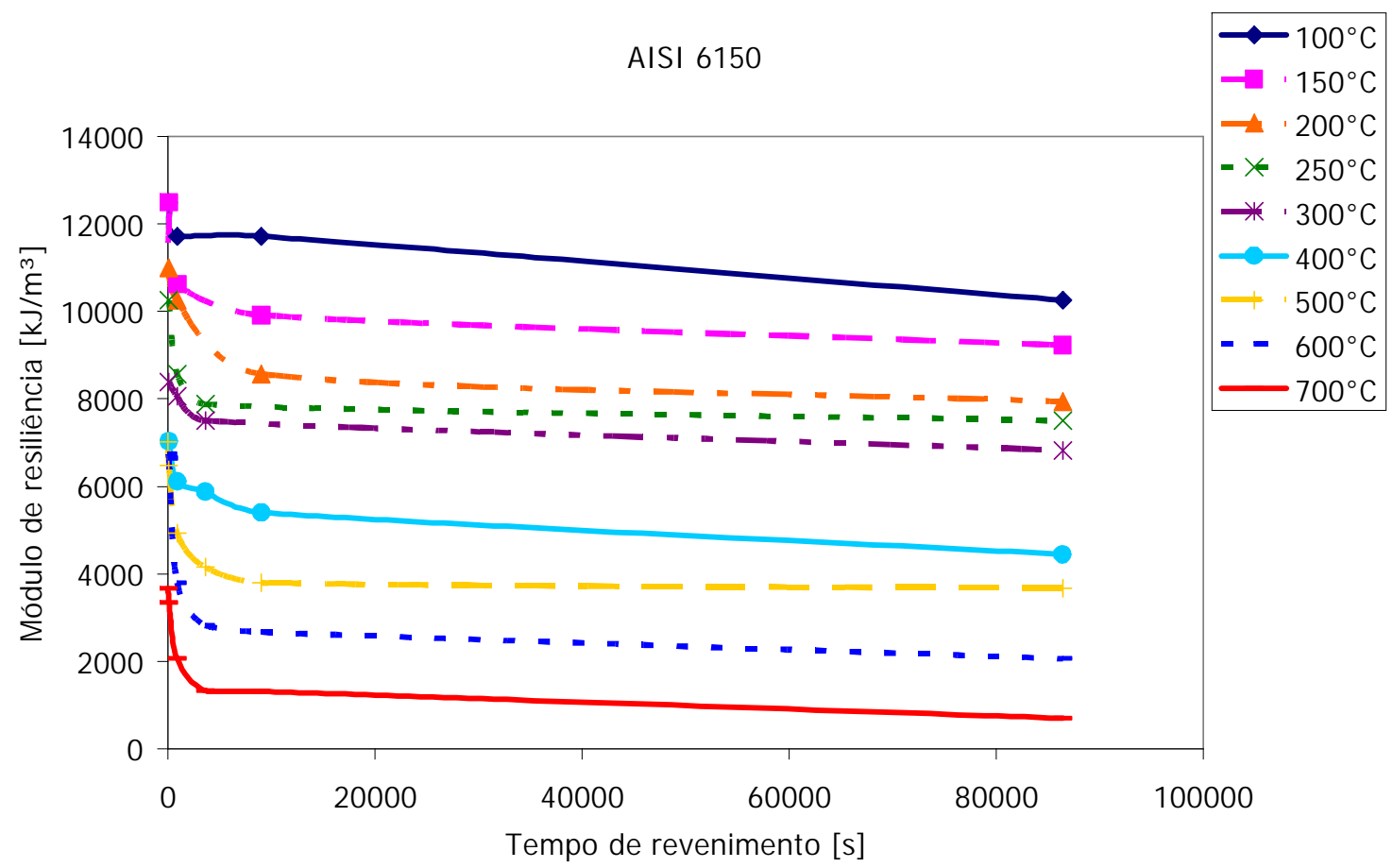

Figura 55: Módulo de resiliência obtido para o aço AISI 6150. 


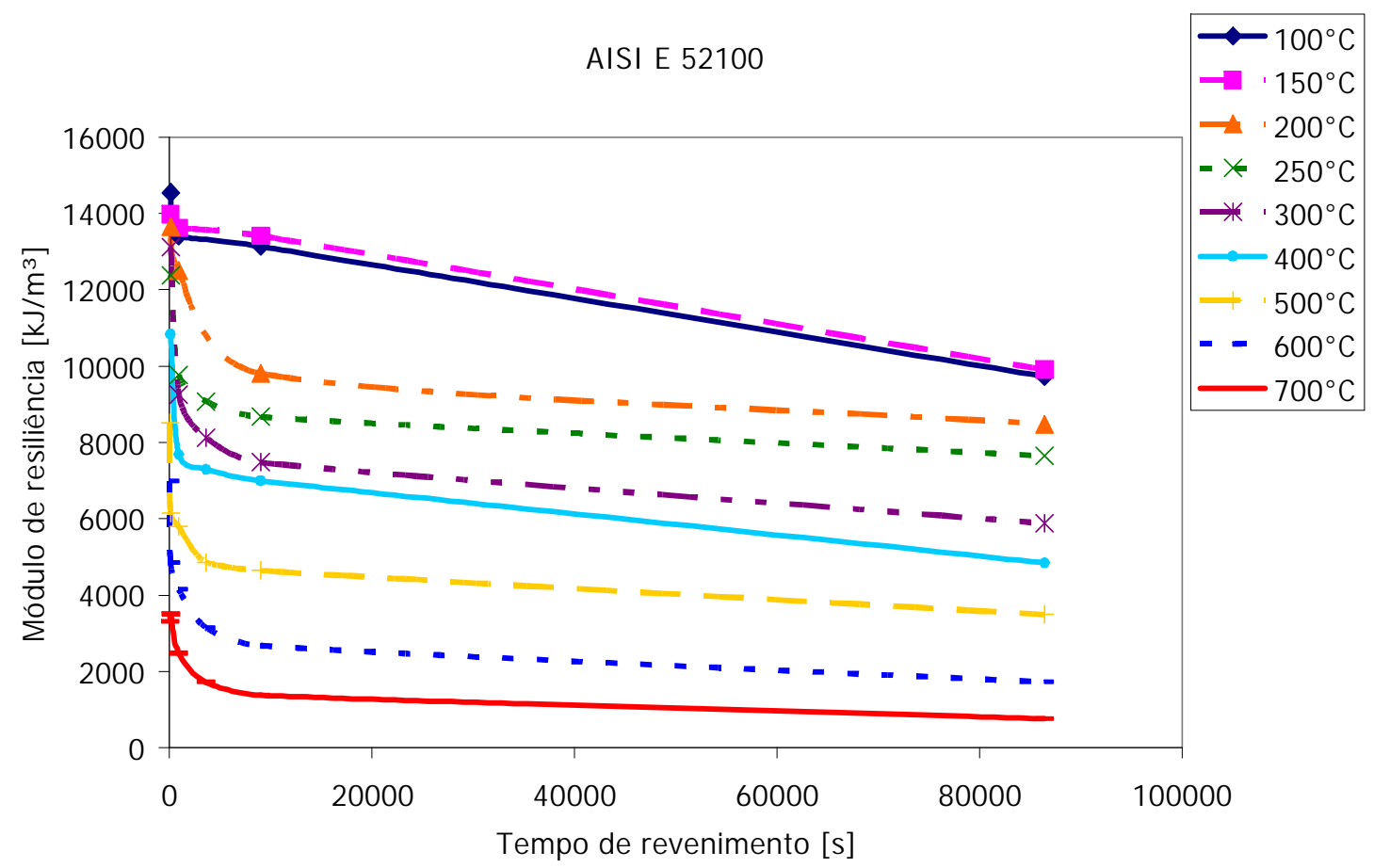

Figura 56: Módulo de resiliência obtido para o aço AISI E52100.

O módulo de tenacidade foi calculado pelas equações (75) e (76), podendo ser observado nas Figuras 57, 58, 59, 60 e 61 para os aços AISI 4140, 4340, 5160, 6150 e E52100 respectivamente. 0 módulo de tenacidade reflete a resistência e a ductilidade do material e corresponde a área total da curva tensão-deformação. Nestas figuras é possível observar que em algumas temperaturas há uma queda deste módulo se comparado a uma curva correspondente a uma temperatura de revenimento inferior. Para o aço AISI 4140, assim como para o aço AISI 4340, este efeito acontece entre 250 e $300^{\circ} \mathrm{C}$. Para o aço AISI 5160 entre 200 e 250ㄷ. Já para o aço AISI 6150 este efeito é mais discreto, mas se nota um decréscimo do módulo de tenacidade a $200^{\circ} \mathrm{C}$. O aço AISI E52100 por sua vez apresenta um comportamento diferenciado no que se refere ao módulo de tenacidade: abaixo de $400^{\circ}$ C nota-se que há um distanciamento das curvas de revenimento e, que na faixa de 200-250ㄷ C há uma queda acentuada do módulo de tenacidade. Observa-se também que os corpos de prova revenidos por uma hora tendem a melhorar sua tenacidade especialmente nas temperaturas mais altas e para os aços com $0,4 \%$ de carbono. 


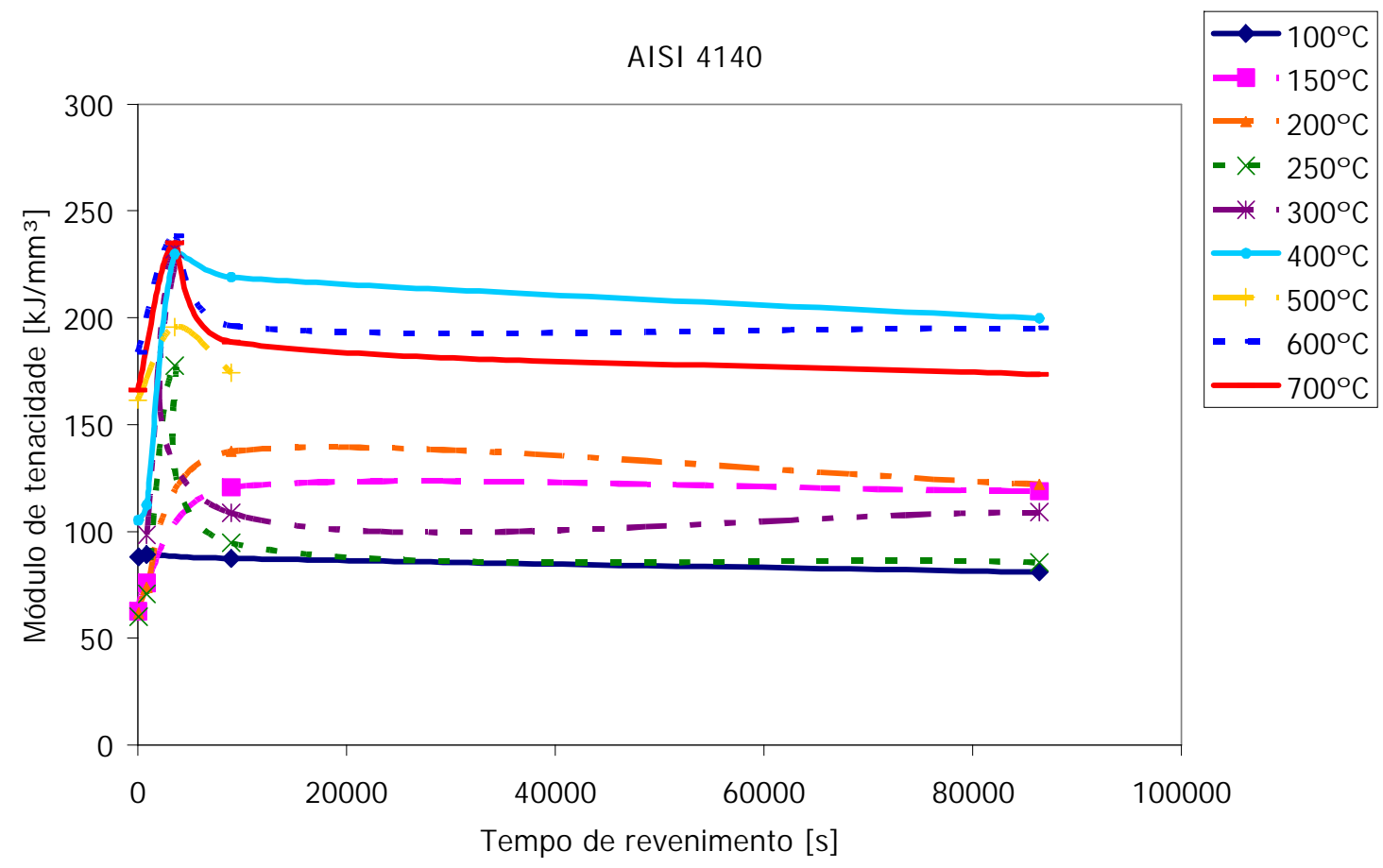

Figura 57: Módulo de tenacidade obtido para o aço AISI 4140 revenido em diferentes condições.

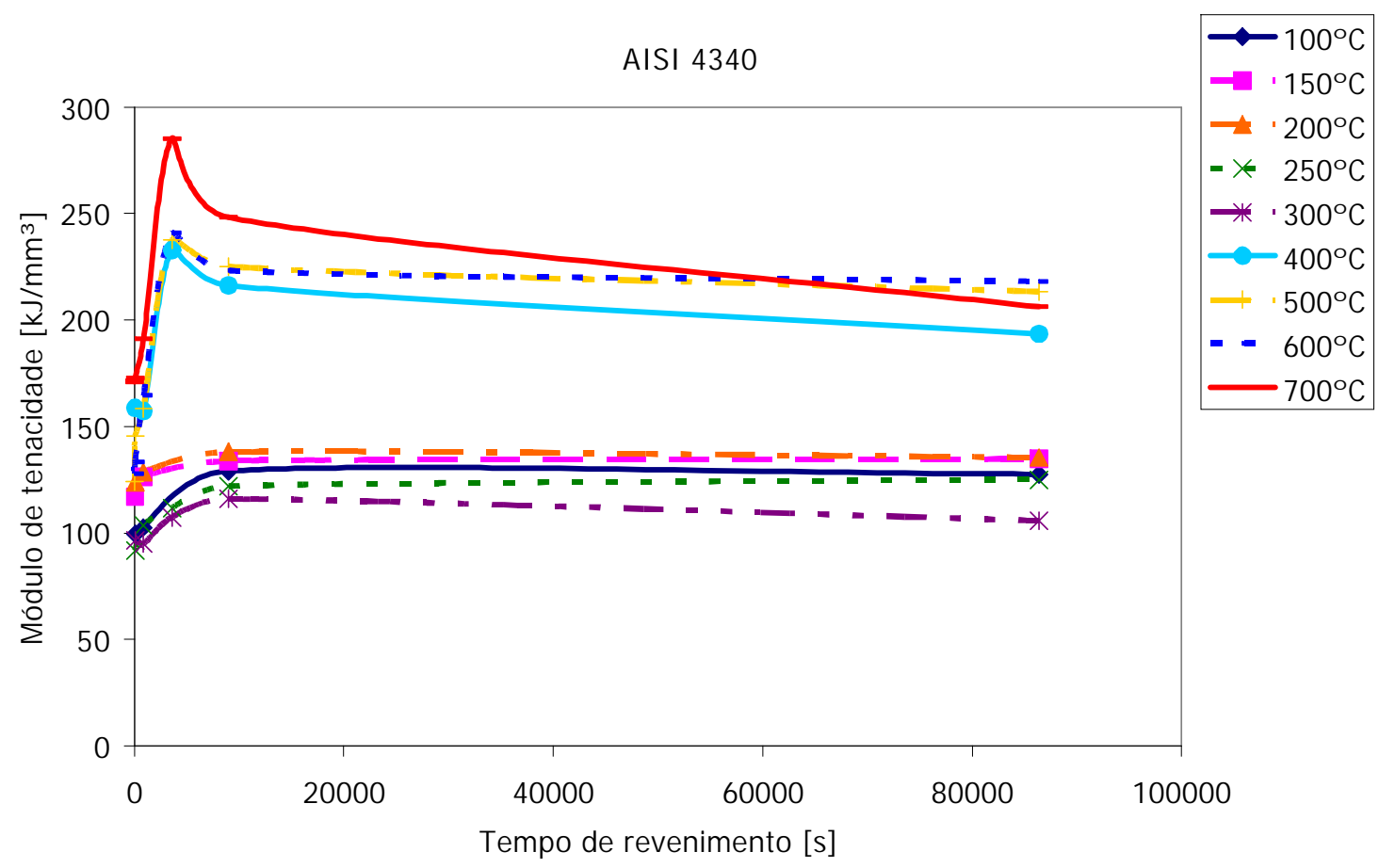

Figura 58: Módulo de tenacidade obtido para o aço AISI 4340 revenido em diferentes condições. 


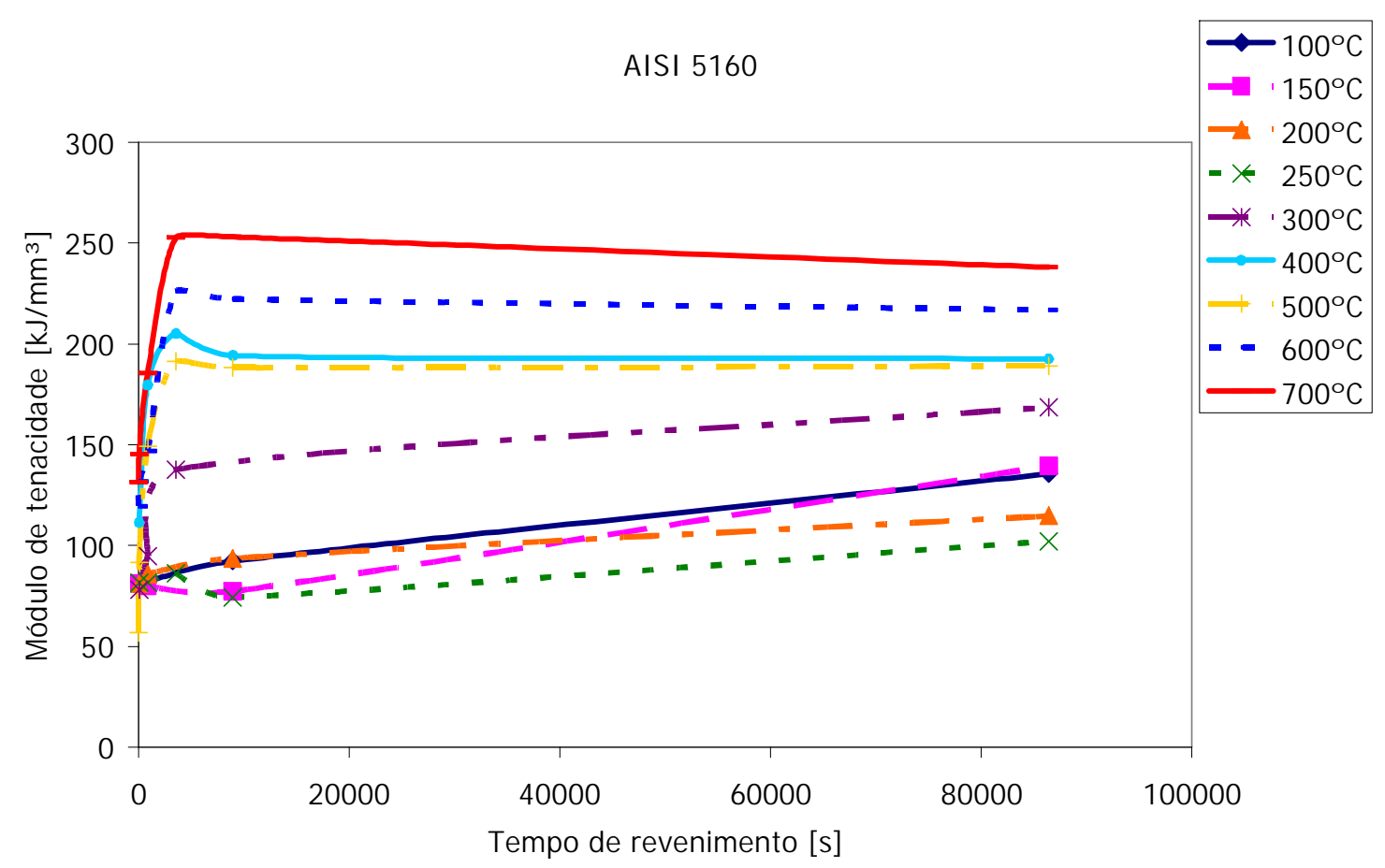

Figura 59: Módulo de tenacidade obtido para o aço AISI 5160 revenido em diferentes condições.

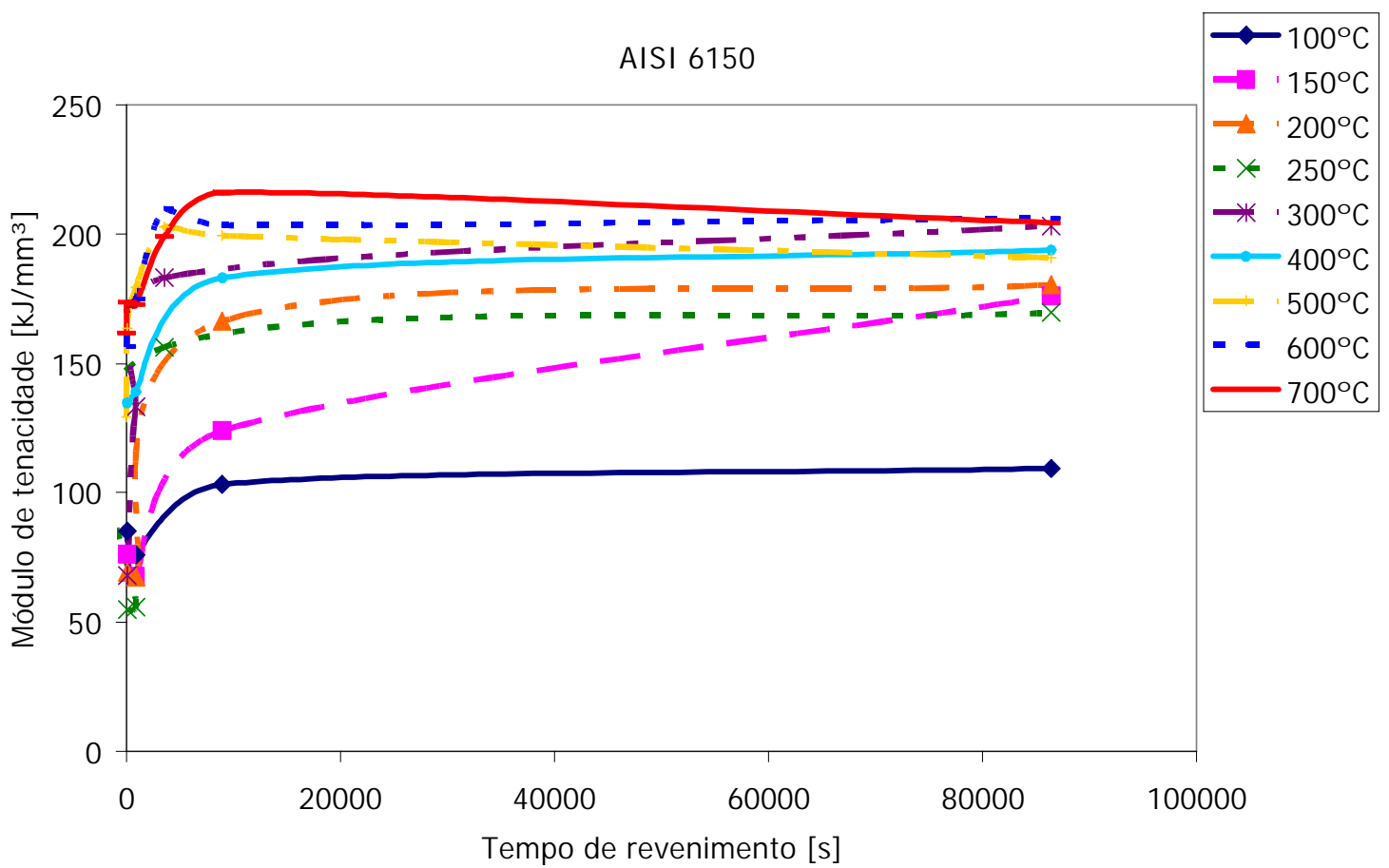

Figura 60: Módulo de tenacidade obtido para o aço AISI 6150 revenido em diferentes condições. 


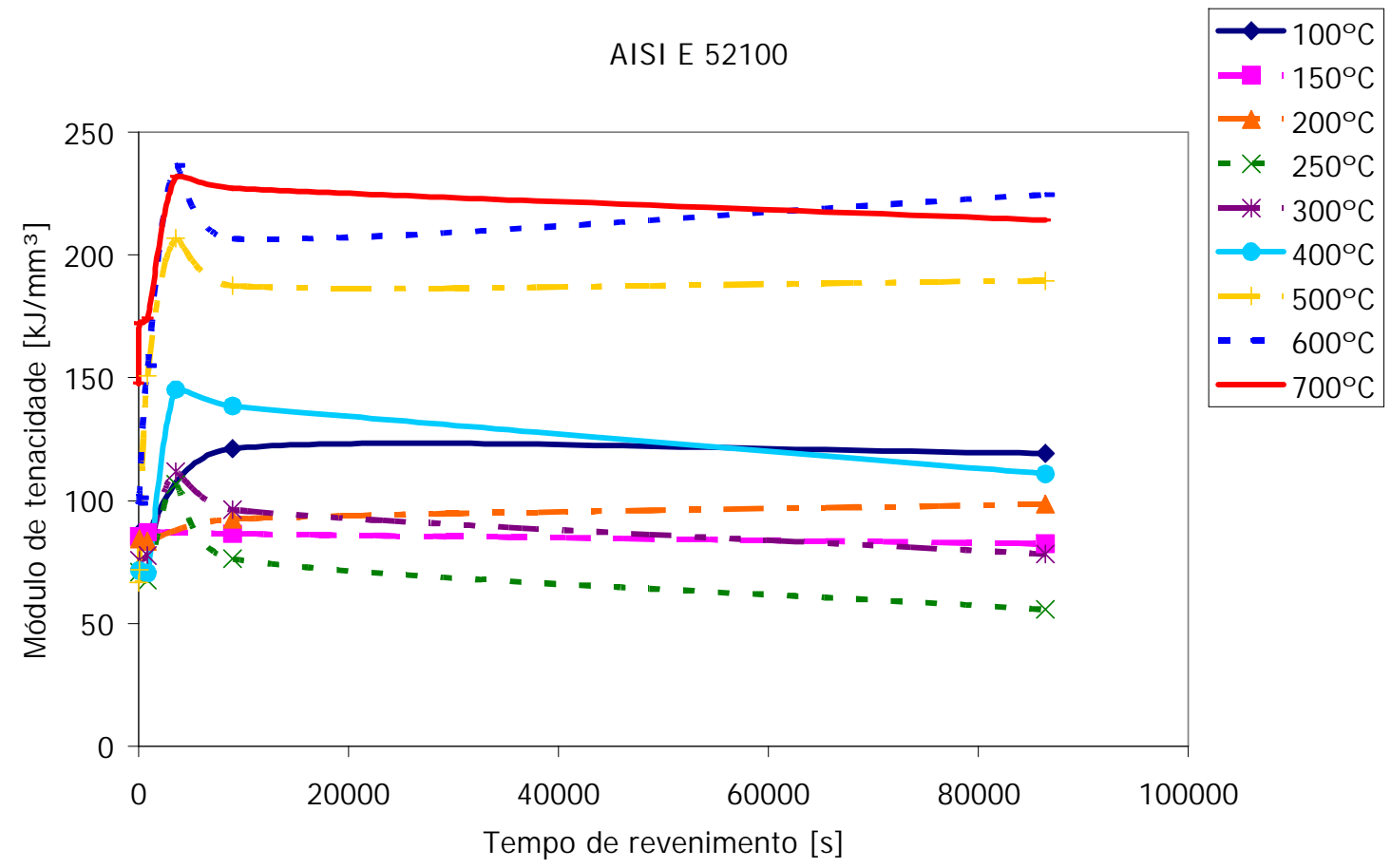

Figura 61: Módulo de tenacidade obtido para o aço AISI E52100 revenido em diferentes condições.

\subsection{RESULTADOS SI MULADOS}

A modelagem por redes neurais foi feita através do programa MatLab. Devido ao tamanho da amostra de dados e o número elevado de variáveis de saída, total de 6, decidiu-se por construir uma rede isolada para calcular cada propriedade mecânica. Esta decisão implicou na diminuição dos parâmetros livres da rede o que facilitou a sua convergência. Para se chegar a um modelo definitivo, centenas de redes foram testadas para cada problema. Aqui será apresentado apenas o modelo que gerou o melhor ajuste em cada caso.

\subsubsection{Dureza}

A base de dados utilizada para construir a rede neural de dureza é composta pelos dados obtidos experimentalmente na seção anterior e pelos dados utilizados por Grange e Baughman (1956). Os valores utilizados por Grange e Baughman (1956) podem ser verificados no Anexo A. A Tabela 17 mostra as variáveis de entrada da rede e seus respectivos valores máximo, mínimo, médio e desvio padrão. 
Tabela 17: Variáveis de entrada da rede projetada para modelar a dureza.

\begin{tabular}{lcccc}
\hline Variáveis de entrada & Min. & Max. & Média & Desvio Padrão \\
\hline Temperatura [으 & 99 & 704 & 410 & 174 \\
Tempo [s] & 10 & 115200 & 20215 & 33143 \\
$\% \mathrm{C}$ & 0,36 & 1,02 & 0,487 & 0,182 \\
$\% \mathrm{Mn}$ & 0,4 & 0,88 & 0,727 & 0,125 \\
$\% \mathrm{P}$ & 0,012 & 0,026 & 0,018 & 0,003 \\
$\% \mathrm{~S}$ & 0,014 & 0,032 & 0,022 & 0,006 \\
$\% \mathrm{Si}$ & 0,15 & 0,28 & 0,215 & 0,039 \\
$\% \mathrm{Ni}$ & 0 & 3,41 & 0,677 & 1,015 \\
$\% \mathrm{Cr}$ & 0 & 1,42 & 0,762 & 0,412 \\
$\% \mathrm{Mo}$ & 0 & 0,33 & 0,107 & 0,128 \\
\hline
\end{tabular}

Para modelar os dados de dureza concluiu-se que o melhor algoritmo é o Levenberg-Marquardt modificado com regularização bayesiana, com a soma dos erros quadráticos (SSE) como função de desempenho e sem validação cruzada. Para chegar a esta conclusão centenas de redes foram previamente testadas.

O conjunto de dados foi divido em um conjunto para treinamento e outro para teste da rede. 0 conjunto de teste corresponde a $10 \%$ do conjunto total escolhido randomicamente com o objetivo de se obter um grupo mais representativo do problema. Os dados de entrada e de saída foram normalizados no intervalo [-1,1].

A arquitetura da rede pode ser vista no desenho esquemático da Figura 62, onde se nota que a rede continha 10 variáveis de entrada e 3 camadas, sendo que nas camadas intermediárias haviam 15 neurônios em cada uma com função de ativação igual a tangente hiperbólica, e um neurônio na camada de saída com uma função de ativação linear. Os parâmetros utilizados no treinamento podem ser observados na Tabela 18.

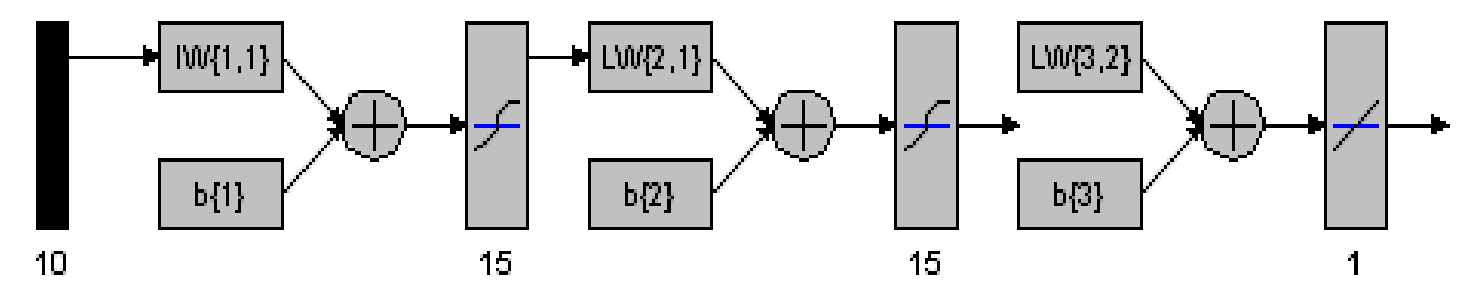

Figura 62: Rede neural com 10 variáveis de entrada e duas camadas ocultas e uma camada de saída. 
Tabela 18: Parâmetros de treinamento da rede de dureza.

\begin{tabular}{ll}
\hline Gradiente mínimo & $1 \mathrm{e}-10$ \\
$\mu$ & 0,005 \\
Decréscimo de $\mu$ & 0,1 \\
Incremento de $\mu$ & 10 \\
Máximo $\mu$ & $1 \mathrm{e}+10$ \\
\hline
\end{tabular}

A Figura 63 traz o decaimento da soma dos erros quadráticos (SSE) durante 0 treinamento. 0 treinamento durou 2001 épocas e a SSE ao final do treinamento foi igual a 2,9 HV. 0 treinamento foi realizado até que um dos critérios de convergência fosse alcançado. Neste caso o algoritmo convergiu quando foi atingido o valor máximo do fator $\mu$. Outro critério de convergência é quando a SSE e a soma dos pesos quadráticos (SSW) se mantêm constantes por várias iterações. Na Figura 64 pode-se analisar o comportamento da SSW durante o processo de treinamento. $\mathrm{Na}$ Figura 65 é possível constatar que foram utilizados 301 parâmetros na redução dos pesos e que a rede continha um total de 421 parâmetros, indicando que a rede estava bem dimensionada para representar o problema.

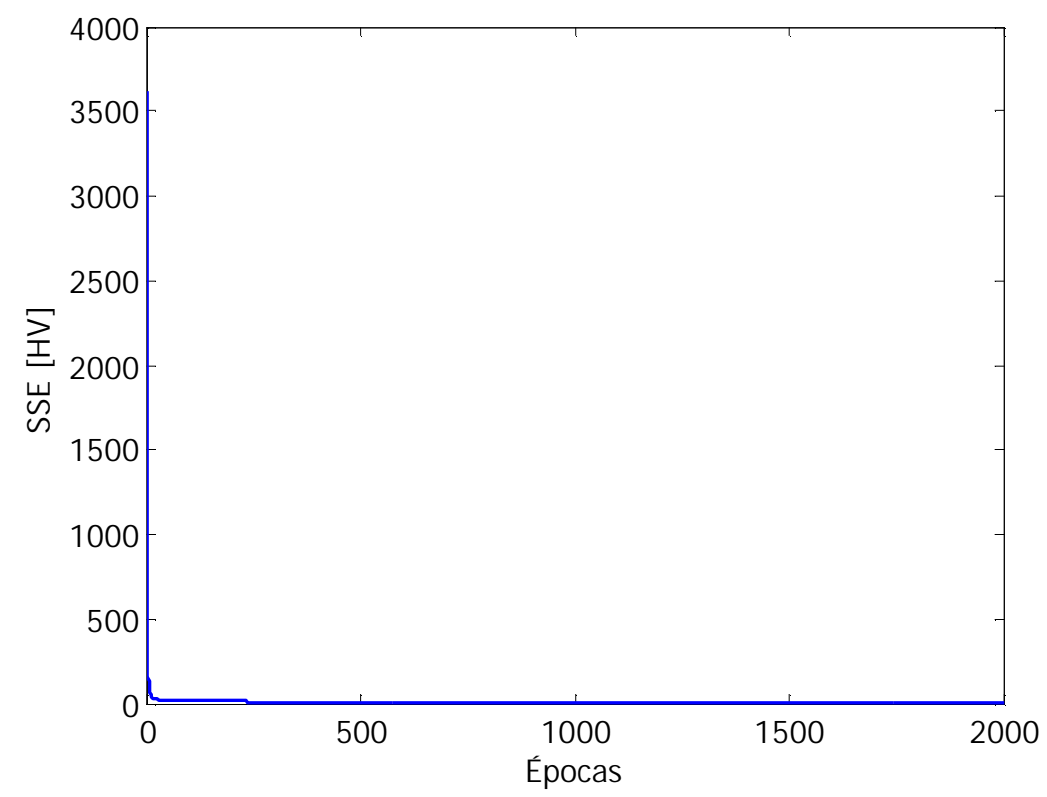

Figura 63: Decaimento do erro durante 0 treinamento da RNA construída para calcular a dureza. 


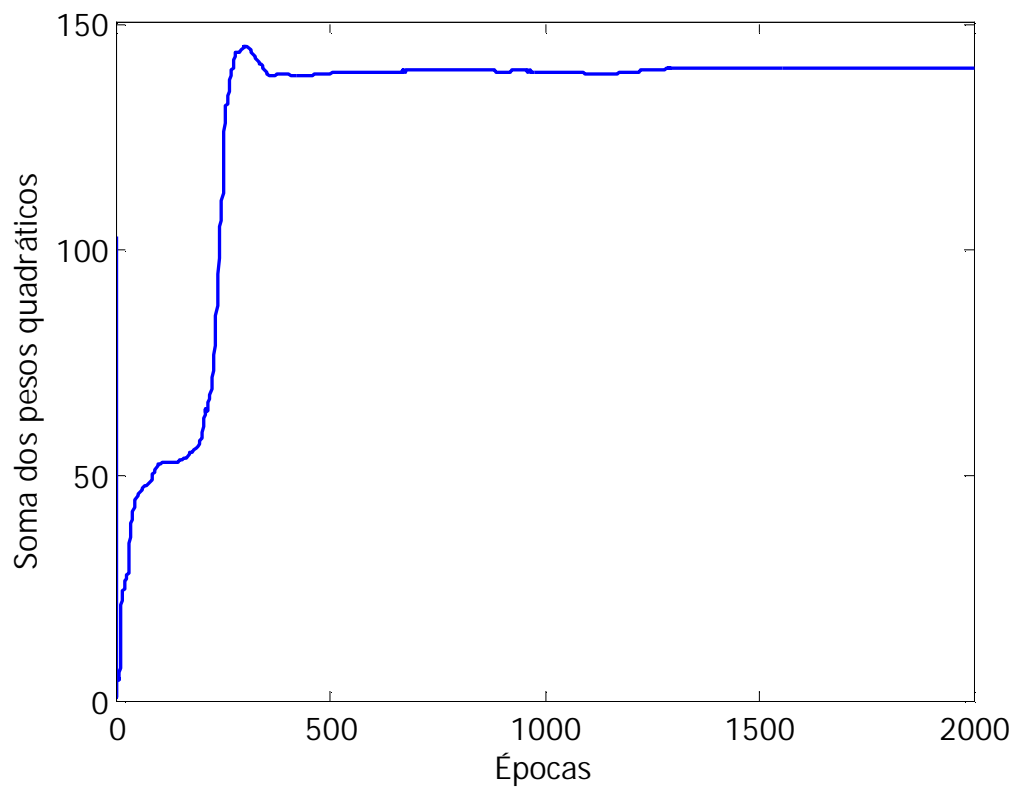

Figura 64: Soma dos pesos quadráticos durante o treinamento da RNA construída para calcular a dureza.

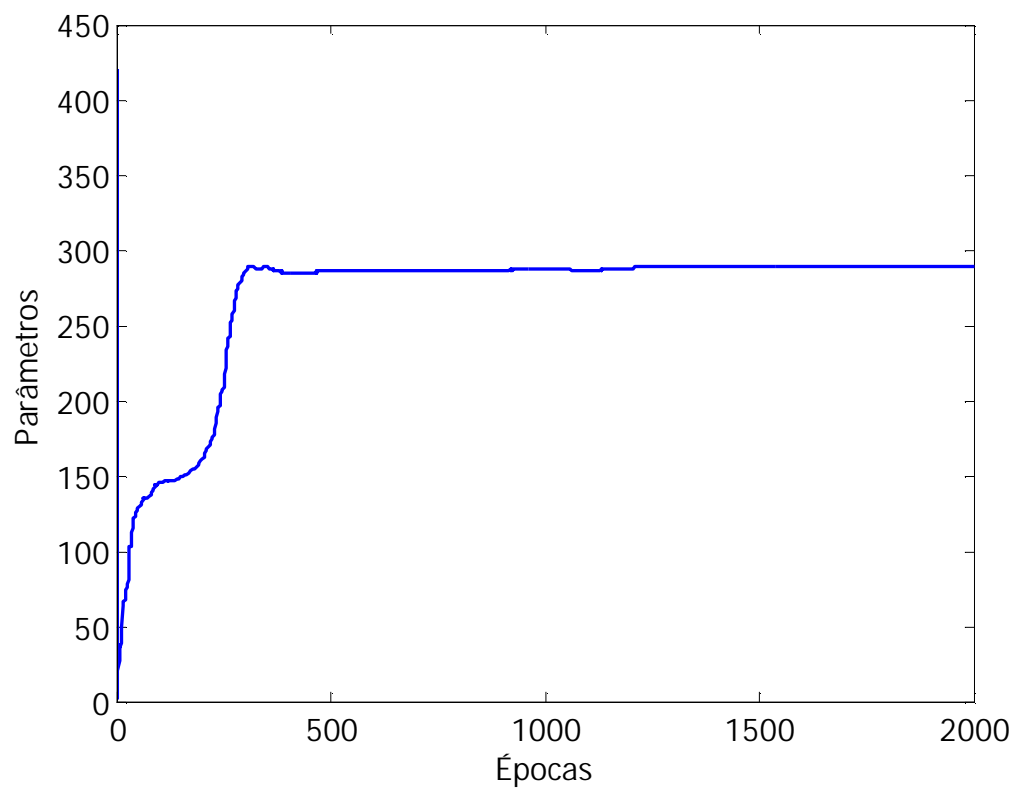

Figura 65: Parâmetros efetivamente utilizados durante o treinamento da RNA construída para calcular a dureza. 
Para validar a rede escolhida foi feita uma análise estatística comparando os valores de dureza medidos e os valores calculados pela RNA. O coeficiente de Pearson para o conjunto de teste foi igual a 0,993 e para o conjunto de treinamento igual a 0,983 indicando que o grupo modelado pela RNA tem forte correlação com 0 grupo experimental. Na Figura 66 observa-se a regressão linear para os dados utilizados no treinamento, onde se verifica que a reta de regressão praticamente se sobrepõe à reta que indicaria a igualdade entre os valores medidos e calculados, indicando um excelente ajuste. De forma análoga, pode-se concluir que para o conjunto de teste o ajuste também foi ótimo, como pode ser visto na Figura 67.

Além da correlação também foi realizada análise de variância para o conjunto de teste, cujo resultado está resumido na Tabela 19. O valor-F calculado foi de 1077 e o valor tabelado de foi de $F_{0,01 ; 54 ; 2}=99,48$ (MONTGOMERY,1997) e, portanto em um intervalo com $99 \%$ de confiança não é permitido rejeitar a hipótese nula. Ou seja, as médias das duas amostras são iguais e, portanto pode-se validar o modelo. De forma análoga o valor-p obtido foi igual a 0,0045 e para um nível de significância de $0,5 \%$ a hipótese nula pode ser considerada verdadeira.

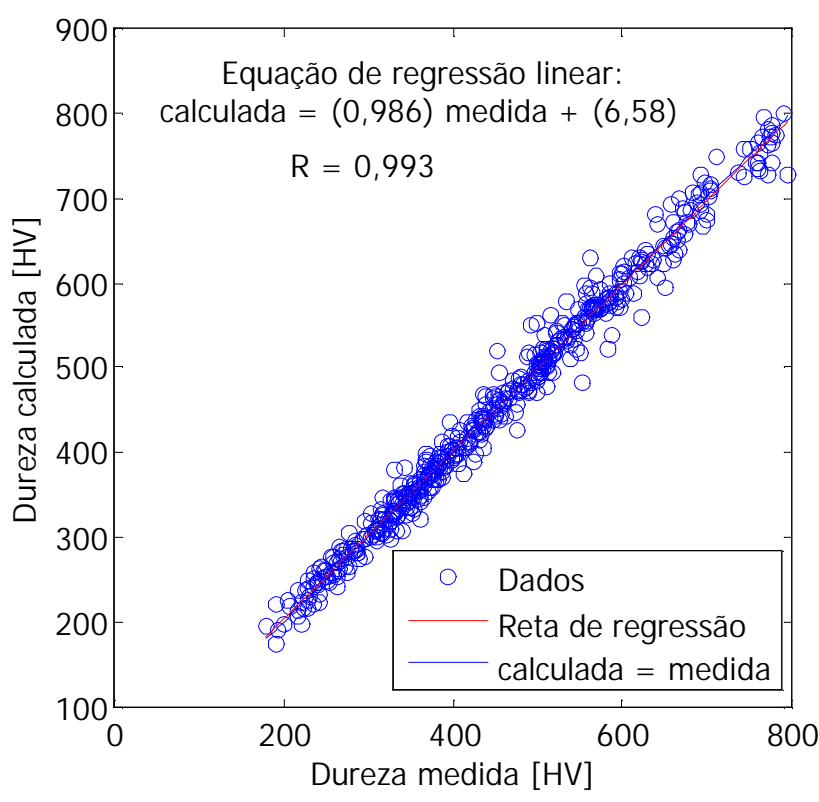

Figura 66: Correlação entre a dureza medida e a dureza calculada pela RNA para o conjunto de treinamento. 


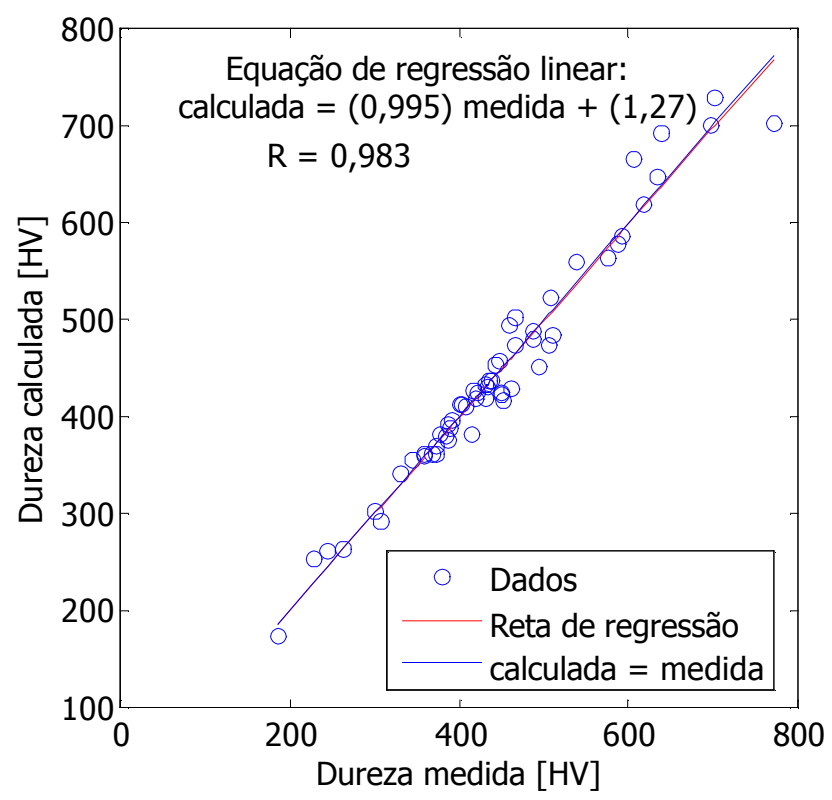

Figura 67: Correlação entre a dureza medida e a dureza calculada pela RNA para o conjunto de teste.

Tabela 19: ANOVA para o conjunto de teste da variável dureza.

\begin{tabular}{ccrrcrc}
\hline & $\begin{array}{r}\text { Graus de } \\
\text { liberdade }\end{array}$ & $\begin{array}{r}\text { Soma dos } \\
\text { quadrados }\end{array}$ & $\begin{array}{r}\text { Quadrados } \\
\text { médios }\end{array}$ & $F$ & $F_{0,01 ; 54 ; 2} *$ & $\begin{array}{c}\text { Valor- } \\
\mathrm{p}\end{array}$ \\
\hline Grupos & 54 & 786294,3 & 14561,01 & 1077,59 & 99,48 & 0,0009 \\
Resíduos & 2 & 27,0 & 13,51 & & & \\
Total & 56 & 786321,3 & & & & \\
\hline$*$ (MONTGOMERY, 1997).
\end{tabular}

As Figuras 68, 69, 70, 71 e 72 mostram a comparação dos resultados experimentais e calculados pela RNA e pelo parâmetro $\mathrm{H}$-J para o conjunto de teste de cada aço testado.

Para calcular a dureza pelo método $\mathrm{H}$-J foi utilizado $c=14,3$ para os aços AISI 5160 e 6150, $c=9,7$ para o aço AISI E52100 e $c=19,5$ para os aços AISI 4140 e 4340. Deve-se ressaltar que o parâmetro de $\mathrm{H}$-J produz resultados de dureza na escala HRC e que a conversão para a escala HV foi feita utilizando a norma da ASTM E $140-07$. 
Na Figura 68 é possível observar o excelente ajuste da RNA para o aço 4140 e como o parâmetro de $\mathrm{H}$-J não funciona bem para os aços ligados.

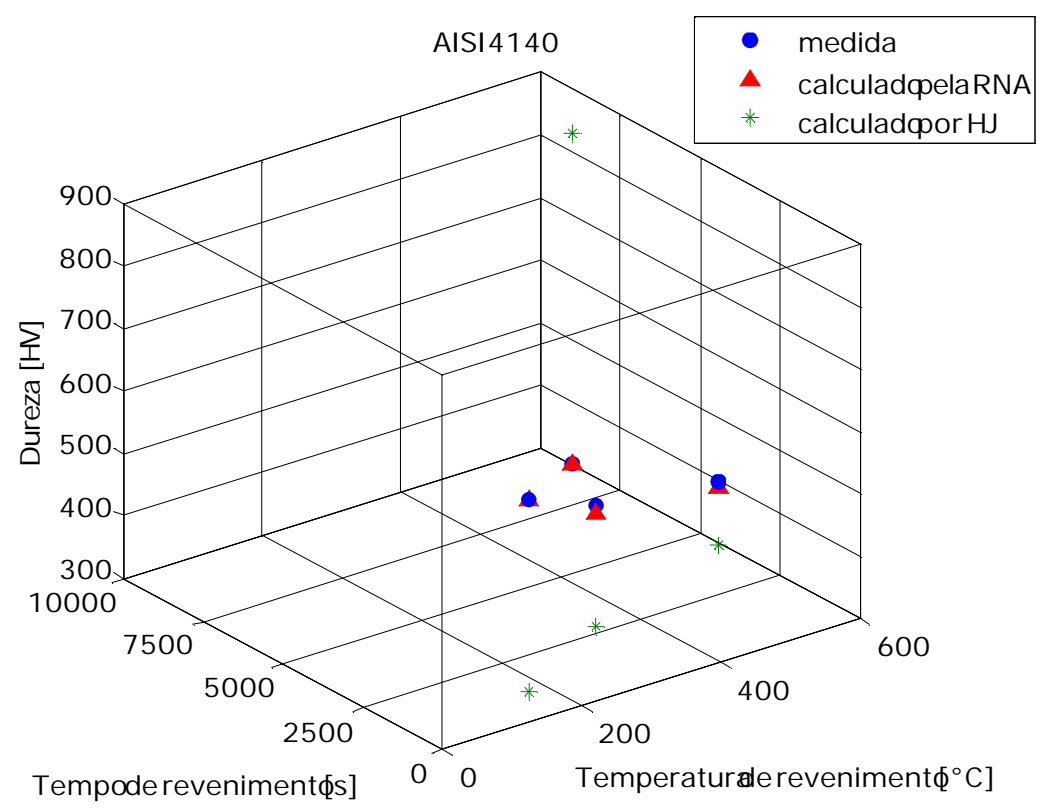

Figura 68: Comparação dos resultados da dureza medida experimentalmente, calculada pela RNA e pelo parâmetro H-J para o aço AISI 4140.

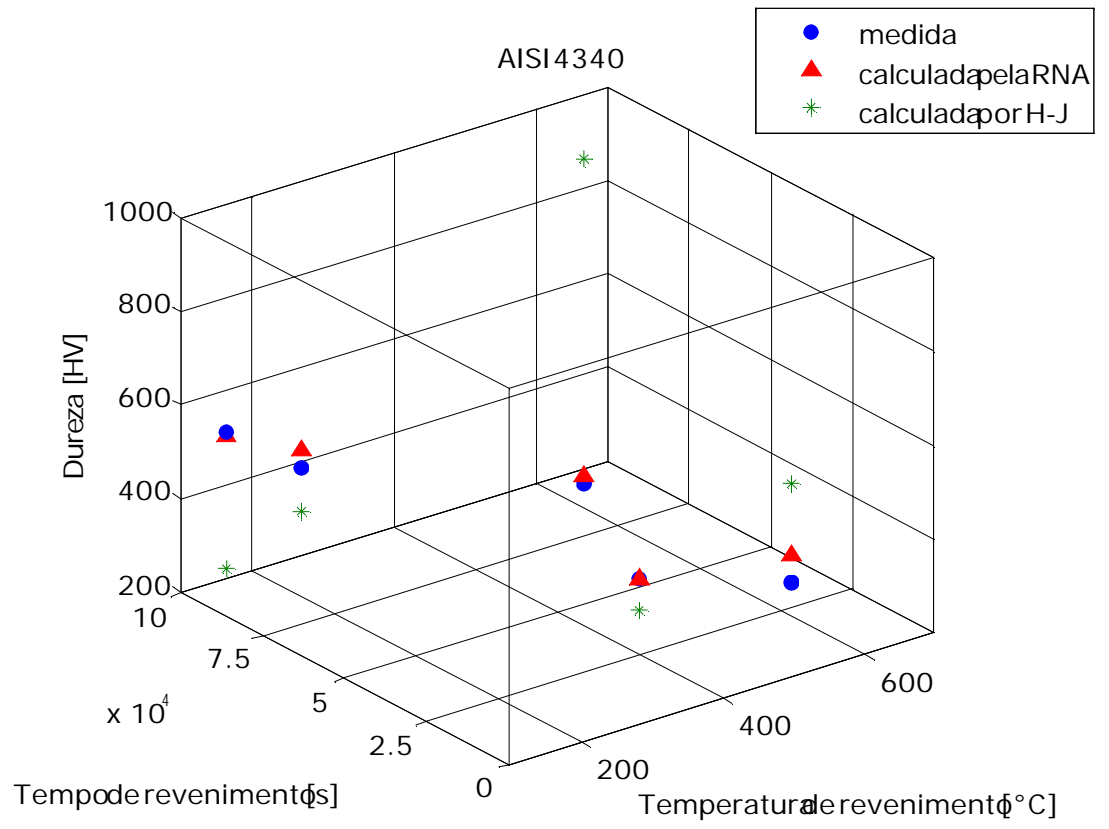

Figura 69: Comparação dos resultados da dureza medida experimentalmente, calculada pela RNA e pelo parâmetro H-J para o aço AISI 4340. 


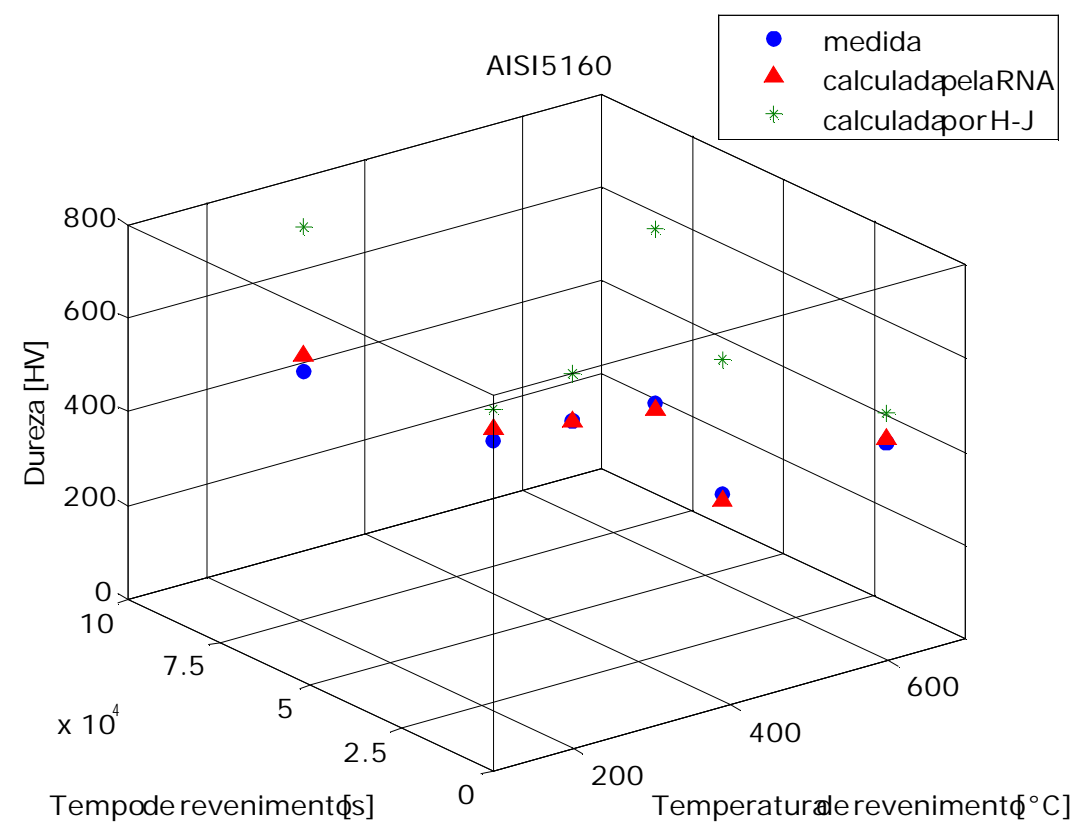

Figura 70: Comparação dos resultados da dureza medida experimentalmente, calculada pela RNA e pelo parâmetro H-J para o aço AISI 5160.

A Figura 71 mostra os dados calculados e medidos para o aço AISI 6150 e a Figura 72 para o aço E52100, onde mais uma vez fica nítido o bom ajuste da modelagem. Os pontos equivalentes a $250^{\circ} \mathrm{C}$ e $9000 \mathrm{~s}$ da Figura 71 podem dar a falsa impressão de que não foram bem ajustados, no entanto esta variação ao ser convertida para escala Rockwell C equivale a aproximadamente $1 \mathrm{HRC}$, sendo portanto um erro perfeitamente aceitável. 


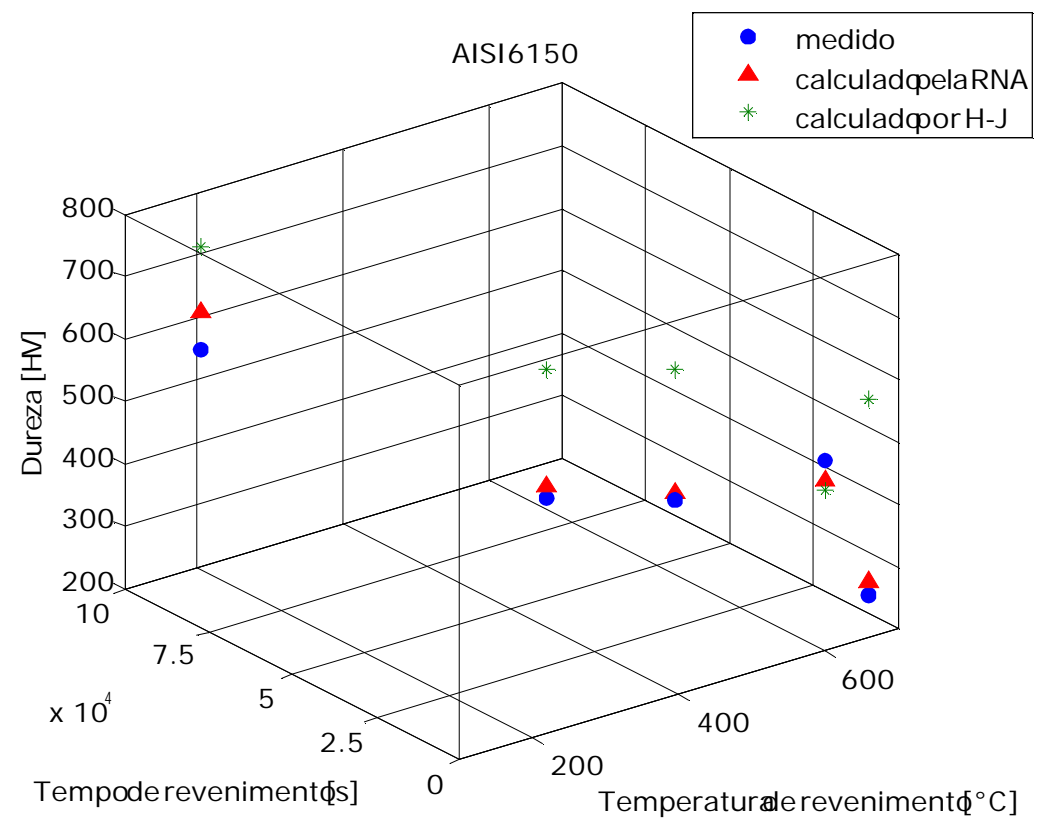

Figura 71: Comparação dos resultados da dureza medida experimentalmente, calculada pela RNA e pelo parâmetro H-J para o aço AISI 6150.

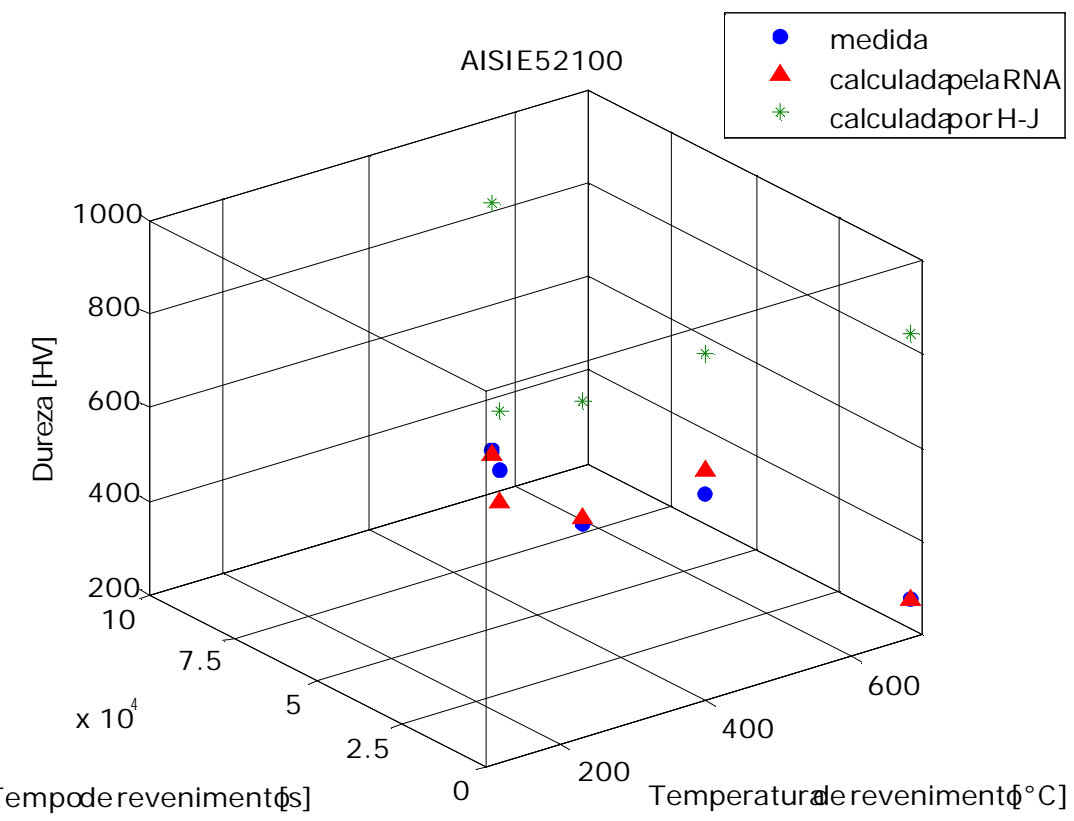

Figura 72: Comparação dos resultados da dureza medida experimentalmente, calculada pela RNA e pelo parâmetro H-J para o aço AISI E52100. 


\subsubsection{Limite de Resistência à tração}

A base de dados utilizada para construir a RNA para calcular o LRT é composta dos dados obtidos experimentalmente na seção 4.1.2 e dos dados da literatura originados pelos trabalhos de Inoue (1980) e Nam et al. (2000). Os valores da literatura podem ser verificados no Anexo B. A Tabela 20 mostra as variáveis de entrada da rede e seus respectivos valores máximo, mínimo, médio e desvio padrão de cada variável da amostra.

Tabela 20: Variáveis de entrada da rede projetada para modelar o LRT e o LE.

\begin{tabular}{lcccc}
\hline Variáveis de entrada & Min. & Max. & Média & Desvio Padrão \\
\hline Temperatura [을 & 99 & 703 & 437 & 179 \\
Tempo [s] & 10 & 3600000 & 153600 & 64538 \\
$\% \mathrm{C}$ & 0,39 & 1,02 & 0,537 & 0,200 \\
$\% \mathrm{Mn}$ & 0,40 & 1,42 & 0,784 & 0,261 \\
$\% \mathrm{P}$ & 0 & 0,024 & 0,017 & 0,006 \\
$\% \mathrm{~S}$ & 0 & 0,019 & 0,014 & 0,005 \\
$\% \mathrm{Si}$ & 0,22 & 1,54 & 0,361 & 0,357 \\
$\% \mathrm{Ni}$ & 0 & 1,74 & 0,217 & 0,576 \\
$\% \mathrm{Cr}$ & 0,04 & 1,42 & 0,813 & 0,402 \\
$\% \mathrm{Mo}$ & 0 & 0,26 & 0,076 & 0,105 \\
\hline
\end{tabular}

A modelagem foi feita através do algoritmo LM modificado com regularização bayesiana, com a soma dos erros quadráticos como função de desempenho e sem validação cruzada. Os dados foram normalizados em um intervalo de média zero e desvio padrão unitário.

O conjunto total de dados foi dividido em dois conjuntos: de teste e de treinamento. Cada um com $17 \%$ e $83 \%$ do total de amostras respectivamente, sendo que o grupo de teste foi retirado de forma aleatória do conjunto total.

Para modelar o LRT foi projetada uma rede com 4 camadas, como mostra a Figura 73. Nas camadas intermediárias, com 7, 7 e 9 neurônios, a função de transferência escolhida foi a tangente hiperbólica e para a camada de saída um função linear. Os parâmetros utilizados no treinamento podem ser observados na Tabela 21. 


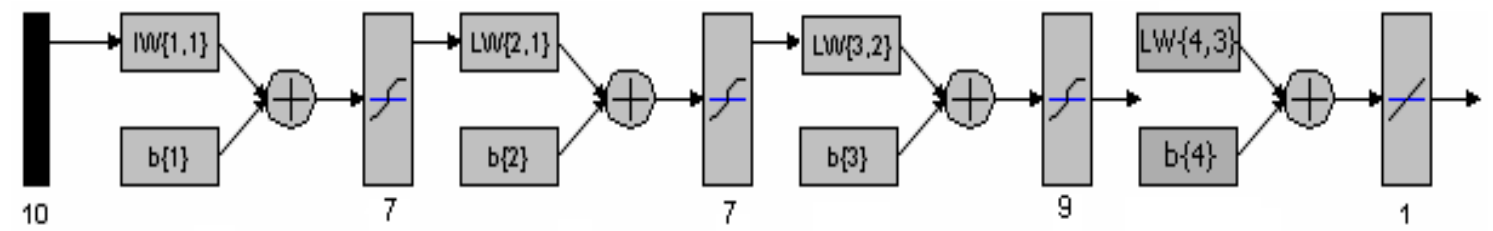

Figura 73: Rede neural com 10 variáveis de entrada e três camadas ocultas e uma camada de saída.

Tabela 21: Parâmetros de treinamento da rede de LRT.

\begin{tabular}{ll}
\hline Gradiente mínimo & $1 \mathrm{e}-10$ \\
$\mu$ & 0,015 \\
Decréscimo de $\mu$ & 0,1 \\
Incremento de $\mu$ & 10 \\
Máximo $\mu$ & $1 \mathrm{e}+10$ \\
\hline
\end{tabular}

0 treinamento durou 344 épocas e foi interrompido quando o fator $\mu$ atingiu seu valor máximo. Ao final do treinamento a função de desempenho apresentava um valor igual a 4,16 MPa. O decréscimo da função de desempenho pode ser observado na Figura 74. As variações da soma dos pesos quadráticos e dos parâmetros utilizados para reduzir os erros durante o treinamento estão nas Figuras 75 e 76 respectivamente.

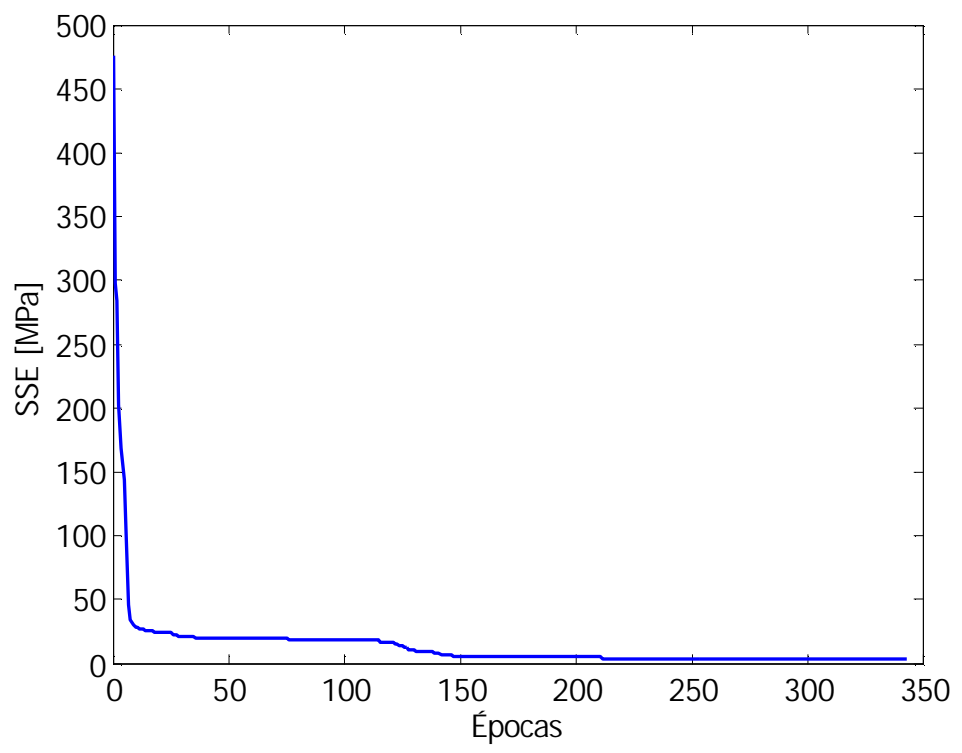

Figura 74: Decaimento do erro durante o treinamento da RNA construída para calcular o LRT. 


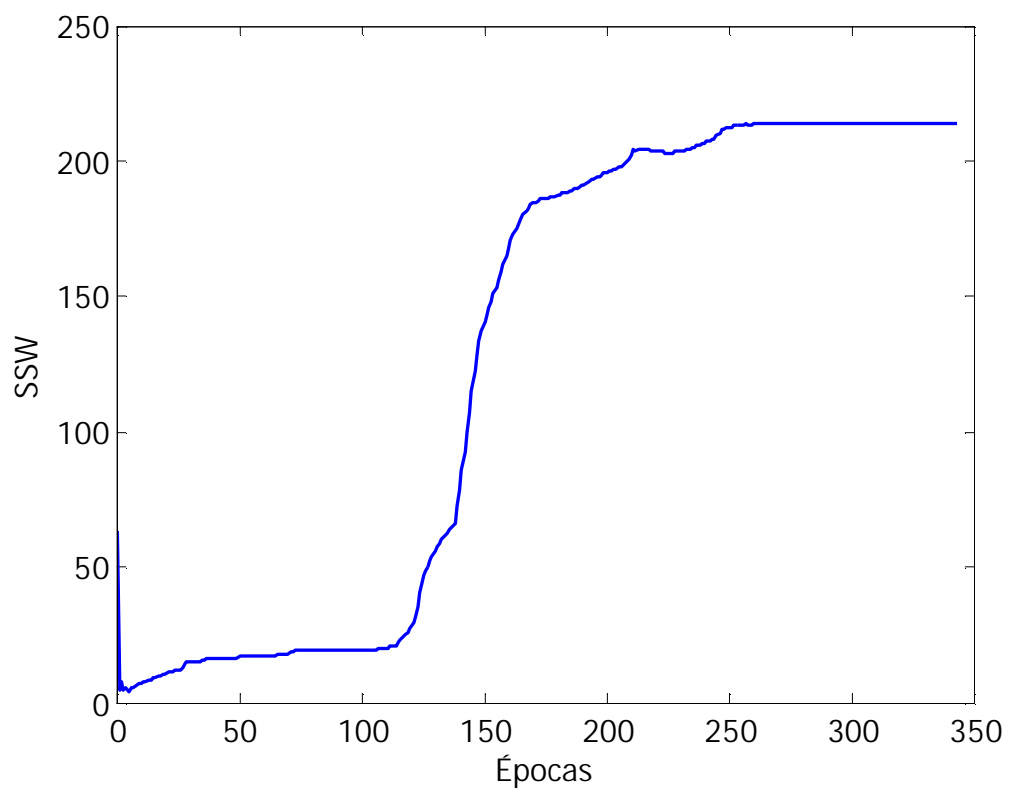

Figura 75: Soma dos pesos quadráticos durante o treinamento da RNA construída para calcular o LRT.

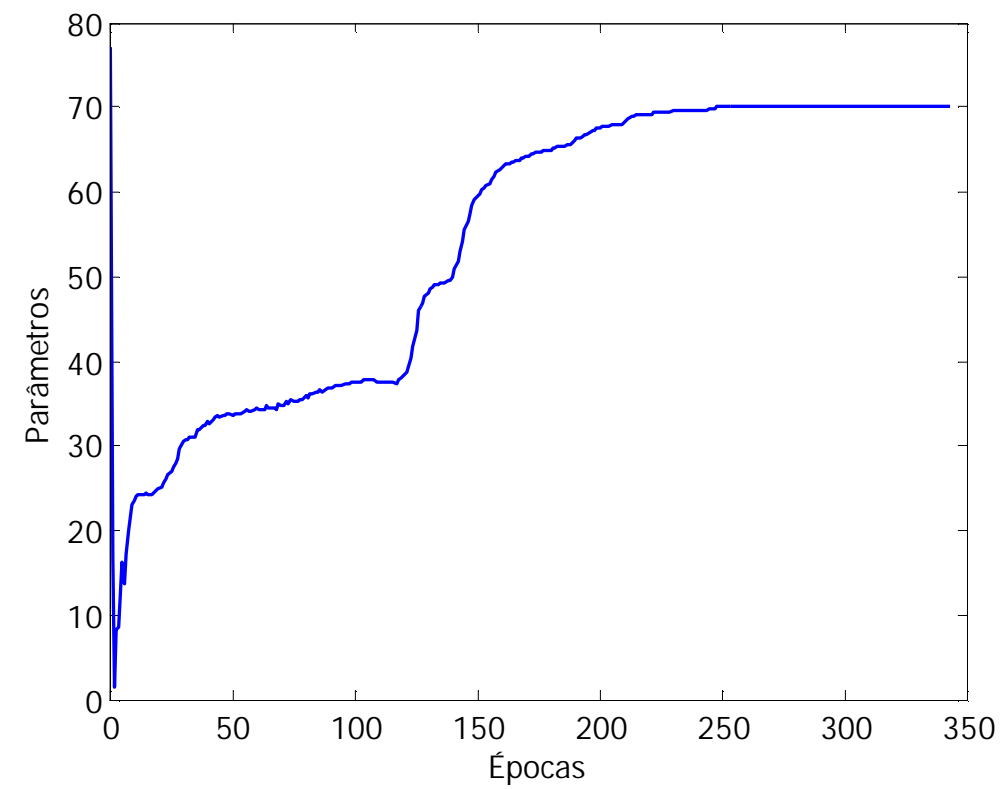

Figura 76: Parâmetros efetivamente utilizados durante 0 treinamento da RNA construída para calcular o LRT.

Para validar a rede escolhida foi feita uma análise estatística comparando os valores do LRT medidos e os valores calculados pela rede neural. A regressão linear para o conjunto de treinamento e para o conjunto de teste pode ser observada nas 
Figuras 77 e 78. 0 nível de correlação entre o LRT medido e o LRT calculado foi excelente tanto para o conjunto de treinamento $(R=0,993)$ quanto para o conjunto de teste $(R=0,989)$. A dispersão dos dados e a regressão linear podem ser observadas nas Figuras 77 e 78, para os conjuntos de treino e de teste, onde se nota um bom ajuste linear para os dois casos.

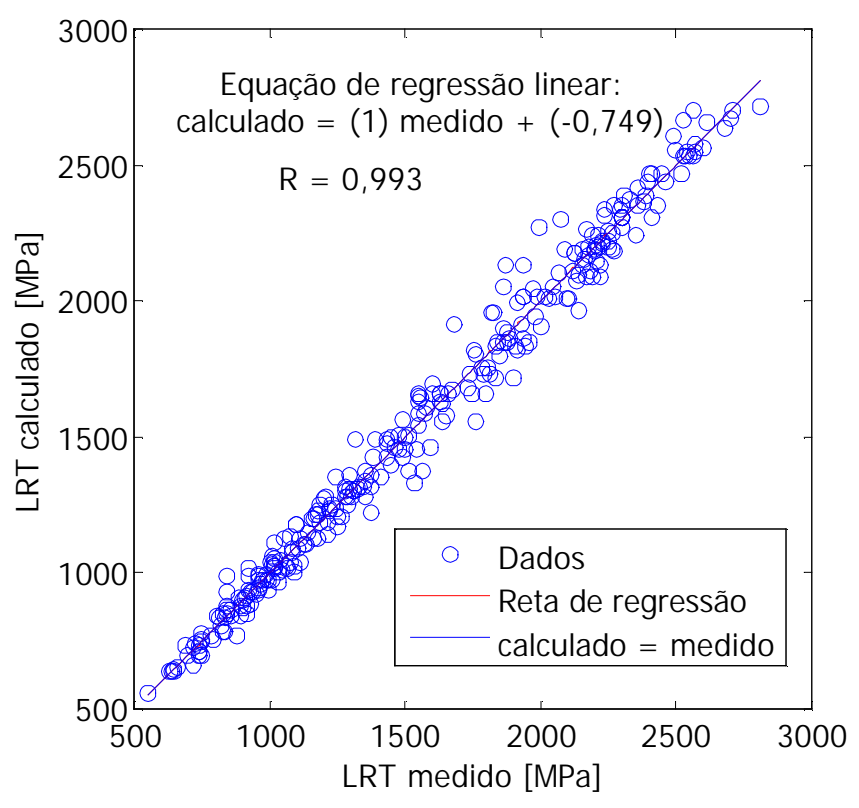

Figura 77: Correlação entre o LRT medido e o LRT calculado pela RNA para 0 conjunto de treinamento. 


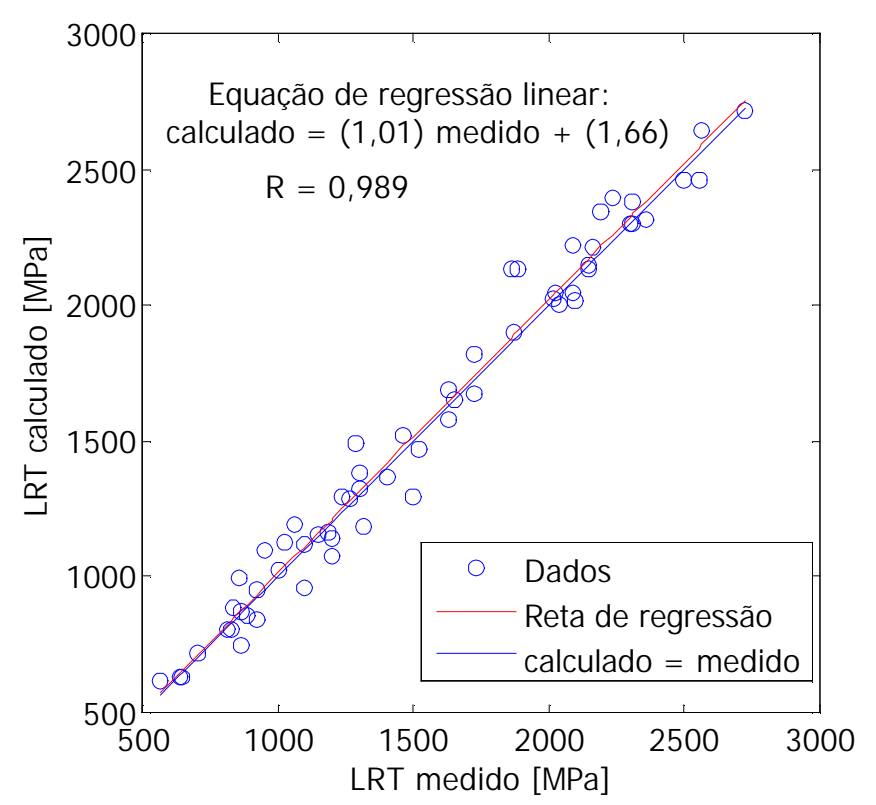

Figura 78: Correlação entre o LRT medido e o LRT calculado pela RNA para o conjunto de teste.

Segundo a análise variância realizada para o conjunto de teste pode-se afirmar com $99 \%$ de confiança que não é permitido rejeitar a hipótese nula, pois o valor de $F$ calculado é superior ao $F$ tabelado. O valor-p obtido foi igual a 0,0079 significa que a um nível de significância de 1\% pode-se aceitar a hipótese nula como verdadeira. Na Tabela 22 são apresentados os dados reverentes à análise de variância que permitiram validar este modelo.

Tabela 22: ANOVA para o conjunto de teste da variável LRT.

\begin{tabular}{ccccccc}
\hline & $\begin{array}{c}\text { Graus de } \\
\text { liberdade }\end{array}$ & $\begin{array}{c}\text { Soma dos } \\
\text { quadrados }\end{array}$ & $\begin{array}{c}\text { Quadrados } \\
\text { médios }\end{array}$ & $\mathrm{F}$ & $\mathrm{F}_{0,01 ; 58 ; 2^{*}}$ & $\begin{array}{c}\text { Valor- } \\
\mathrm{p}\end{array}$ \\
\hline Grupos & 58 & 22302750,41 & 384530,2 & 125,64 & 99,48 & 0,0079 \\
Resíduos & 2 & 6121,15 & 3060,6 & & & \\
$\quad$ Total & 60 & 22308871,56 & & & & \\
\hline *(MONTGOMERY, 1997). & & & & &
\end{tabular}

As Figuras 79, 80, 81, 82 e 83 mostram uma comparação entre as redes testadas e valores obtidos experimentalmente para os aços AISI 4140, 4340, 5160, 6150 e E52100 respectivamente. 


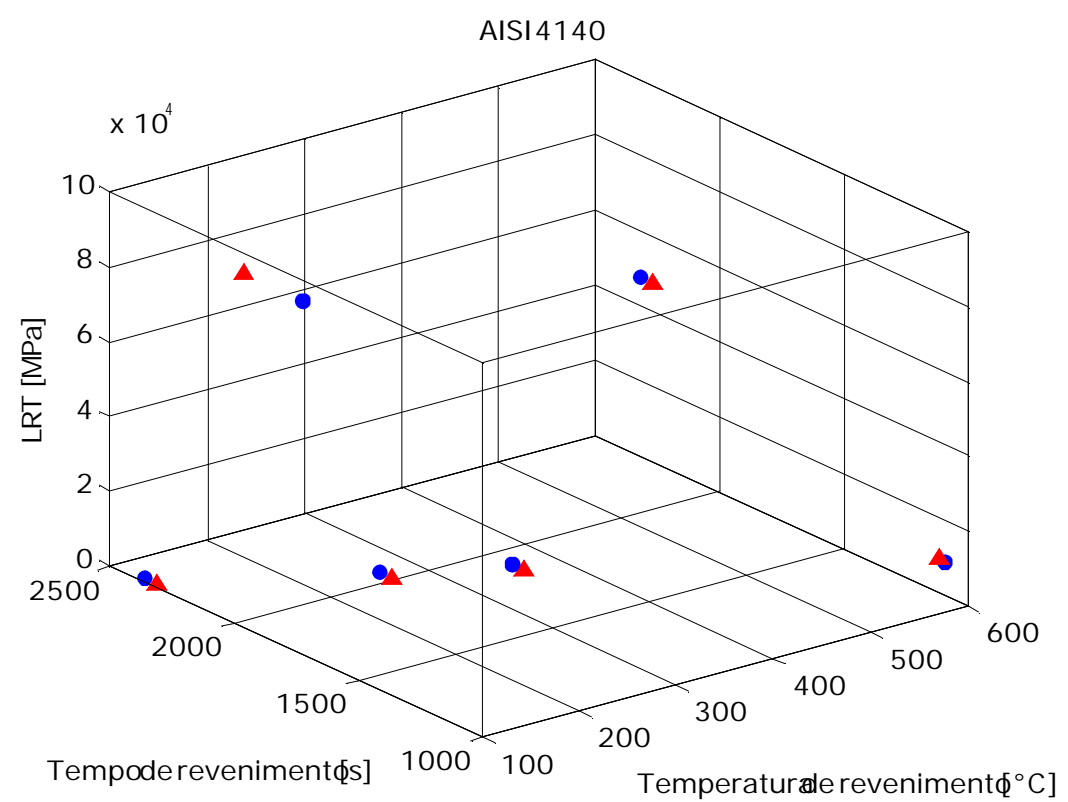

Figura 79: Comparação dos resultados calculados pela RNA com os valores medidos para o LRT obtido pelo conjunto de teste do aço AISI 4140.

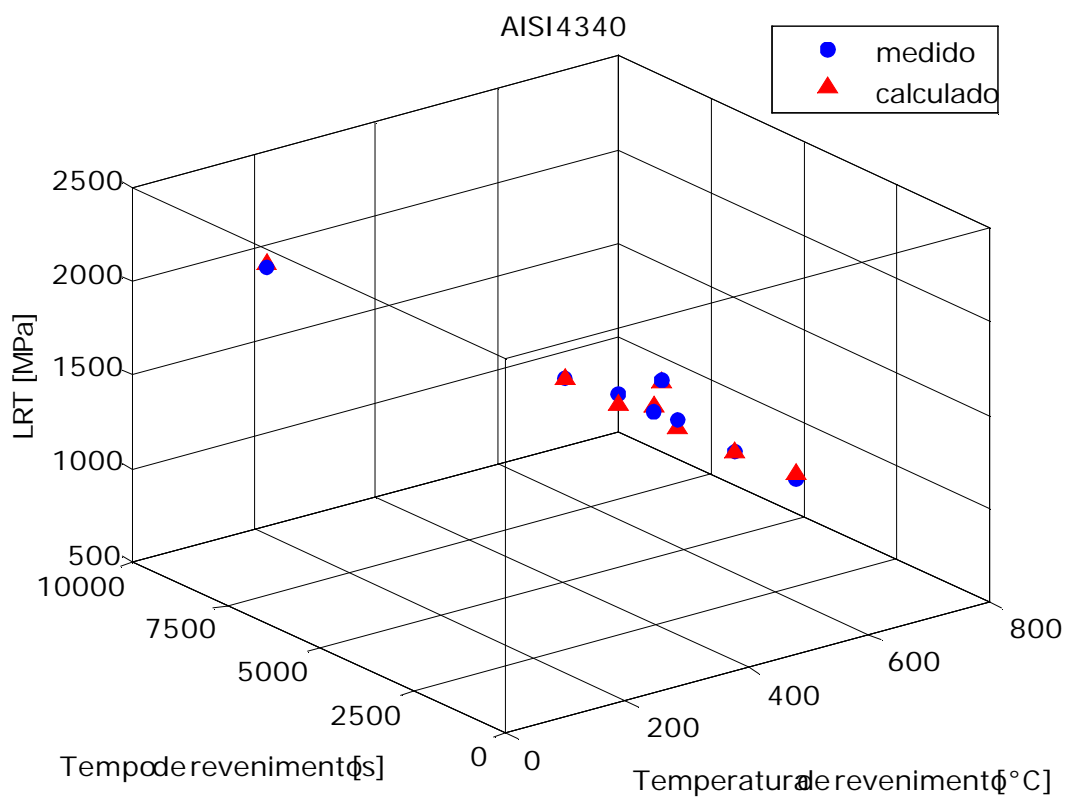

Figura 80: Comparação dos resultados calculados pela RNA com os valores medidos para o LRT obtido pelo conjunto de teste do aço AISI 4340. 


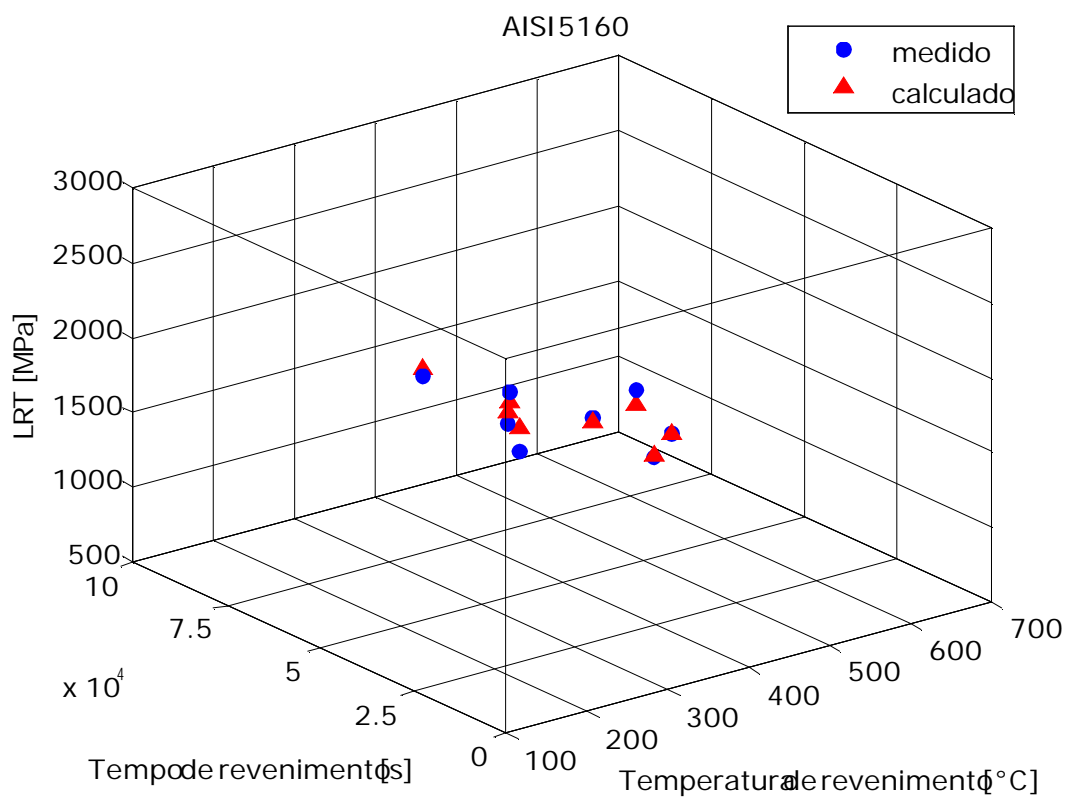

Figura 81: Comparação dos resultados calculados pela RNA com os valores medidos para o LRT obtido pelo conjunto de teste do aço AISI 5160.

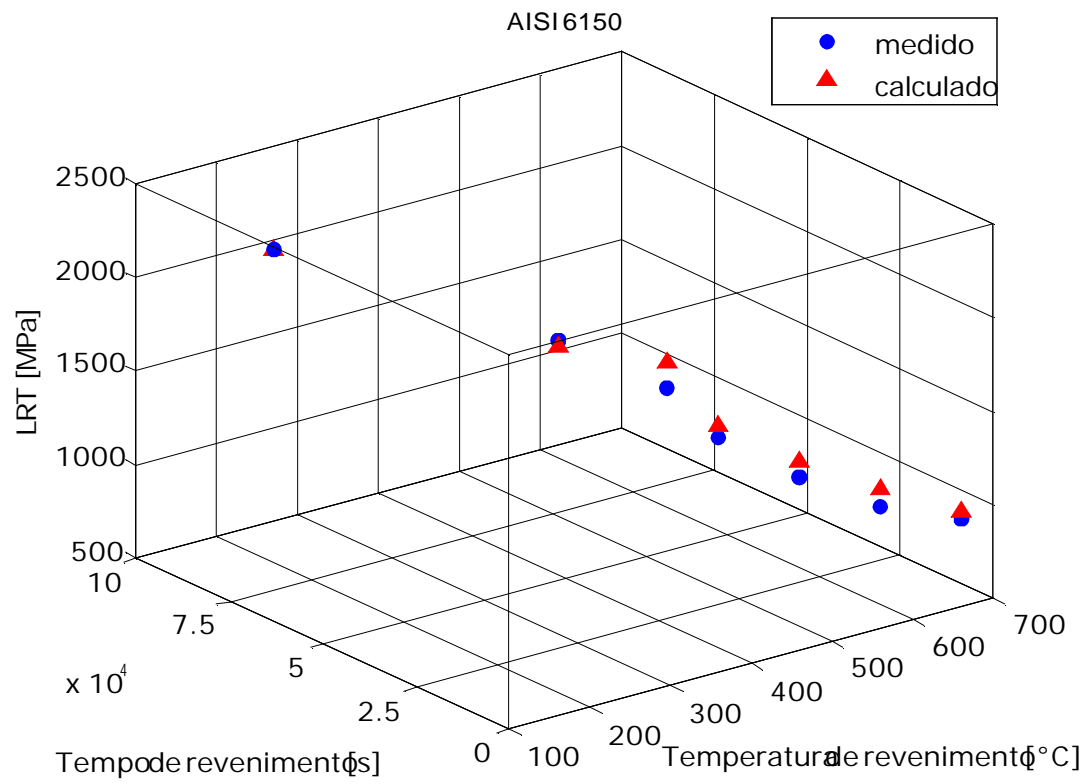

Figura 82: Comparação dos resultados calculados pela RNA com os valores medidos para o LRT obtido pelo conjunto de teste do aço AISI 6150. 


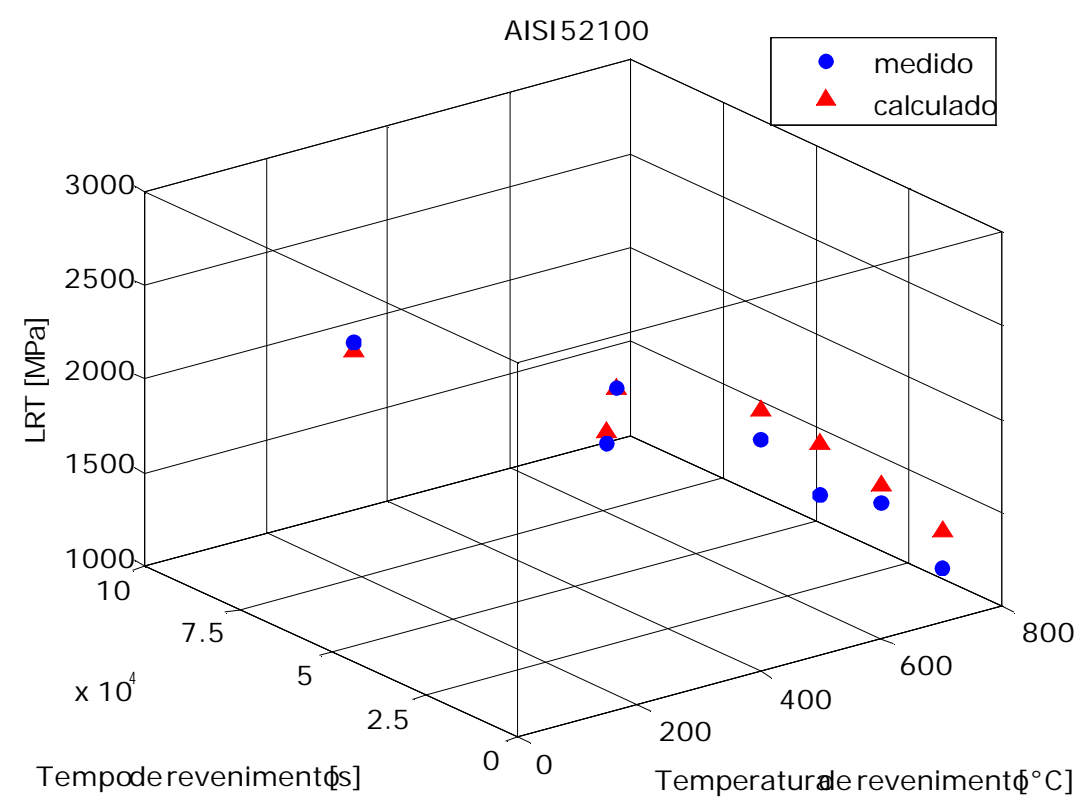

Figura 83: Comparação dos resultados calculados pela RNA com os valores medidos para o LRT obtido pelo conjunto de teste do aço AISI E52100.

\subsubsection{Limite de escoamento}

A base de dados utilizada para construir a RNA para calcular o limite de escoamento foi a mesma utilizada para calcular o limite de resistência à tração (seção 4.2.2) e, portanto suas variáveis de entrada são as mesmas da Tabela 21. A rede construída continha a arquitetura da rede da Figura 84 com 3 camadas, sendo 7 e 14 neurônios nas camadas intermediárias com função de transferência tangente hiperbólica e camada de saída uma função linear.

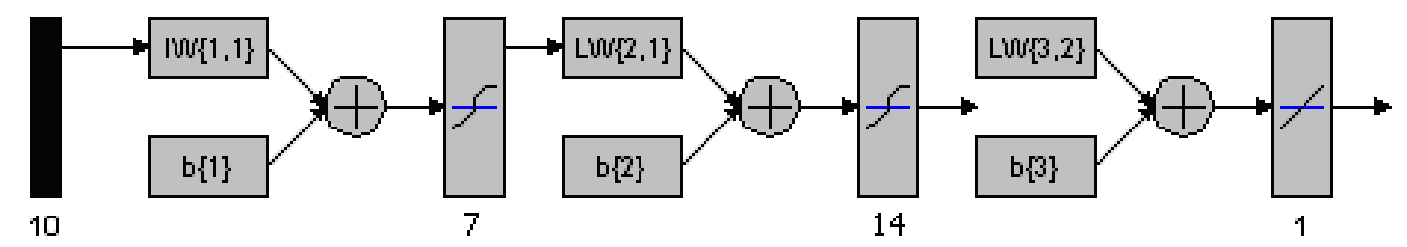

Figura 84: Rede neural com 10 variáveis de entrada e duas camadas ocultas, cada uma com 7 e 14 neurônios e uma camada de saída. 
0 algoritmo escolhido foi o de LM com regularização bayesiana e dados de entrada normalizados em um intervalo de média zero e desvio padrão igual a 1 . 0 conjunto de teste corresponde a $14 \%$ e o conjunto de treinamento a $86 \%$ do total. Os parâmetros utilizados durante o treinamento podem ser vistos na Tabela 21.

Foram realizadas 685 iterações durante o treinamento e o valor do erro ao final deste processo foi igual a 2,2 $\mathrm{MPa}$. 0 treinamento foi interrompido neste ponto pelo programa porque foi atingido o valor máximo do fator $\mu$. A Figura 85 mostra o decaimento do erro durante o treinamento, a Figura 86 a variação da soma dos pesos quadráticos e a Figura 87 os parâmetros utilizados durante o treinamento.

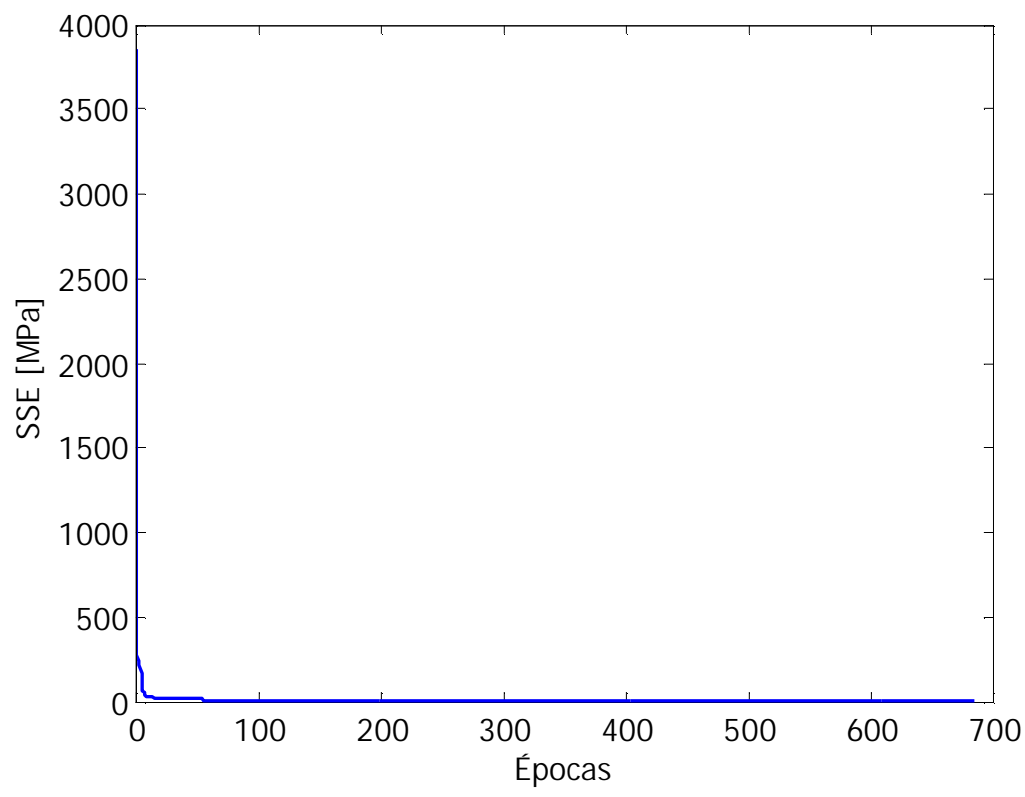

Figura 85: Decaimento do erro durante o treinamento da RNA construída para calcular o limite de escoamento. 


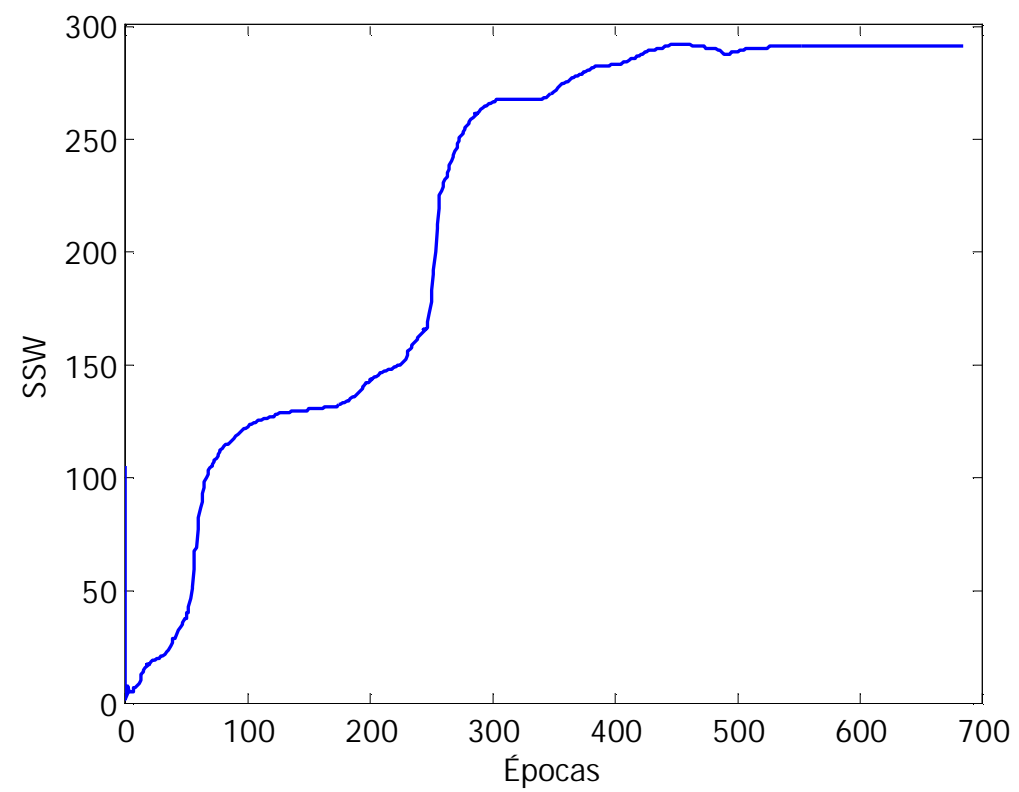

Figura 86: Soma dos pesos quadráticos durante o treinamento da RNA construída para calcular o limite de escoamento.

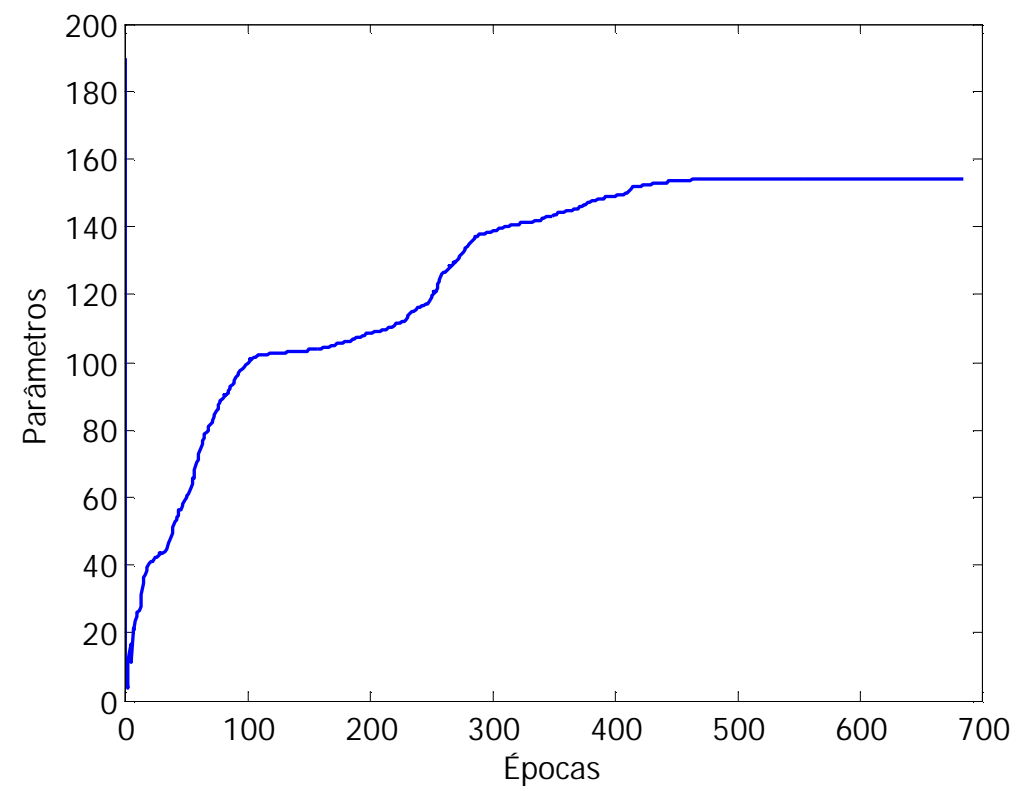

Figura 87: Parâmetros efetivamente utilizados durante o treinamento da RNA construída para calcular o limite de escoamento.

A regressão linear para o conjunto de treinamento e de teste pode ser analisada nas Figuras 88 e 89 respectivamente. 0 que se nota nestas figuras é 0 
bom ajuste linear assim como um excelente coeficiente de correlação para os dois casos ( $R=0,996$ para o treinamento e $R=0,979$ para o teste).

Completando a análise estatística a análise de variância realizada para o grupo de teste mostrou que para um nível de significância de $1 \%$ modelo pode ser validado, pois o valor de $\mathrm{F}$ tabelado é menor que seu valor calculado, permitindo excluir a hipótese alternativa e, consequentemente validar o modelo com um nível de confiança superior a 99\% (valor-p =0,0176). Na Tabela 23 constam os resultados em foram baseadas estas análises.

Tabela 23: ANOVA para o conjunto de teste da variável LE.

\begin{tabular}{lrrrrrr}
\hline & $\begin{array}{c}\text { Graus de } \\
\text { liberdade }\end{array}$ & $\begin{array}{c}\text { Soma dos } \\
\text { quadrados }\end{array}$ & $\begin{array}{c}\text { Quadrados } \\
\text { médios }\end{array}$ & $F$ & $\mathrm{~F}_{0,01 ; 49 ; 2}{ }^{*}$ & Valor-p \\
\hline Grupos & 49 & 11850510,494 & 241847,2 & 567,08 & 99,48 & 0,0018 \\
Resíduos & 2 & 852,95 & 426,5 & & & \\
Total & 51 & 11851363,444 & & & & \\
\hline *(MONTGOMERY, 1997). & & & & &
\end{tabular}

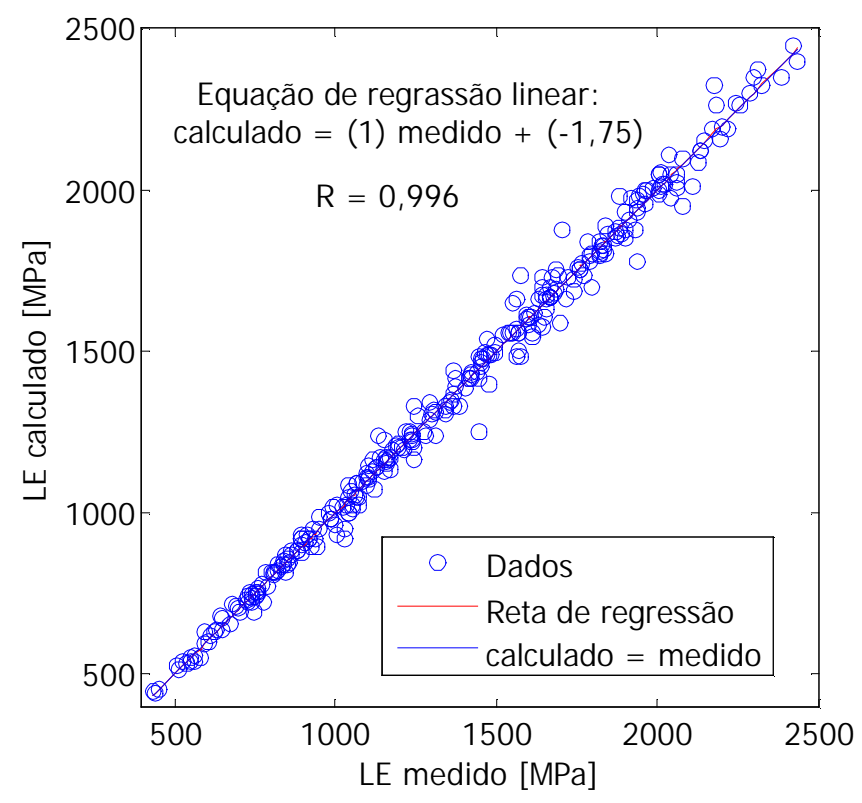

Figura 88: Correlação entre o LE medido e o LE calculado pela RNA para o conjunto de treinamento 


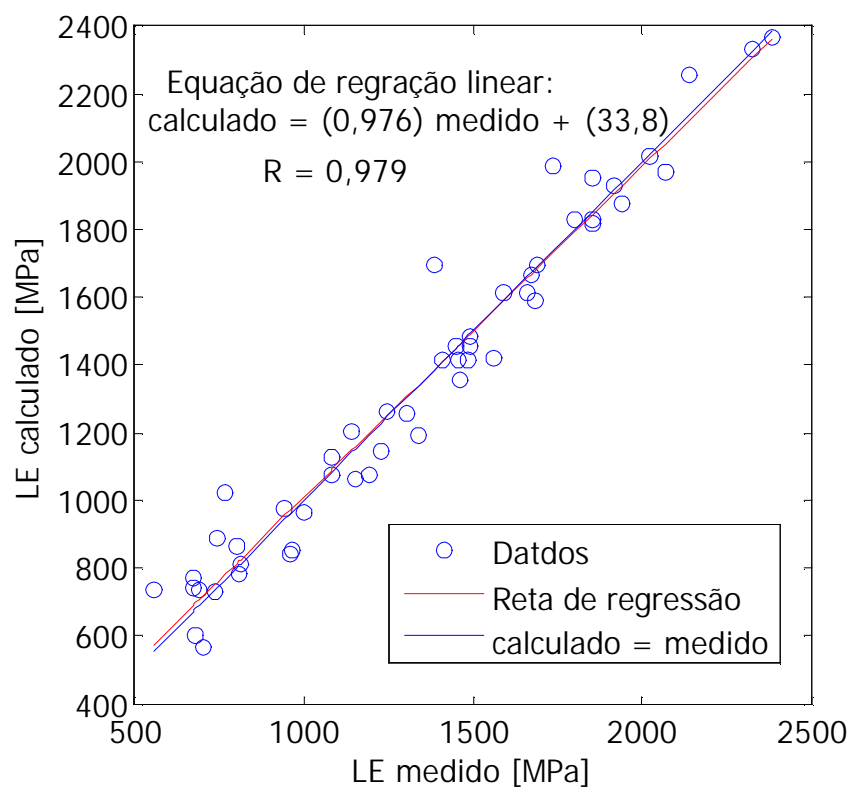

Figura 89: Correlação entre o LE medido e o LE calculado pela RNA para o conjunto de teste.

As Figuras 90, 91, 92, 93 e 94 mostram os valores experimentais e estimados pela rede do conjunto de teste para os aços 4140, 4340, 5160, 6150 e 52100 respectivamente. Em todos os casos pode-se notar que a rede treinada de fato apresenta uma ótima capacidade de generalização, uma vez que consegue ajustar bem dados até então desconhecidos, uma vez que não foram utilizados em seu treinamento. 


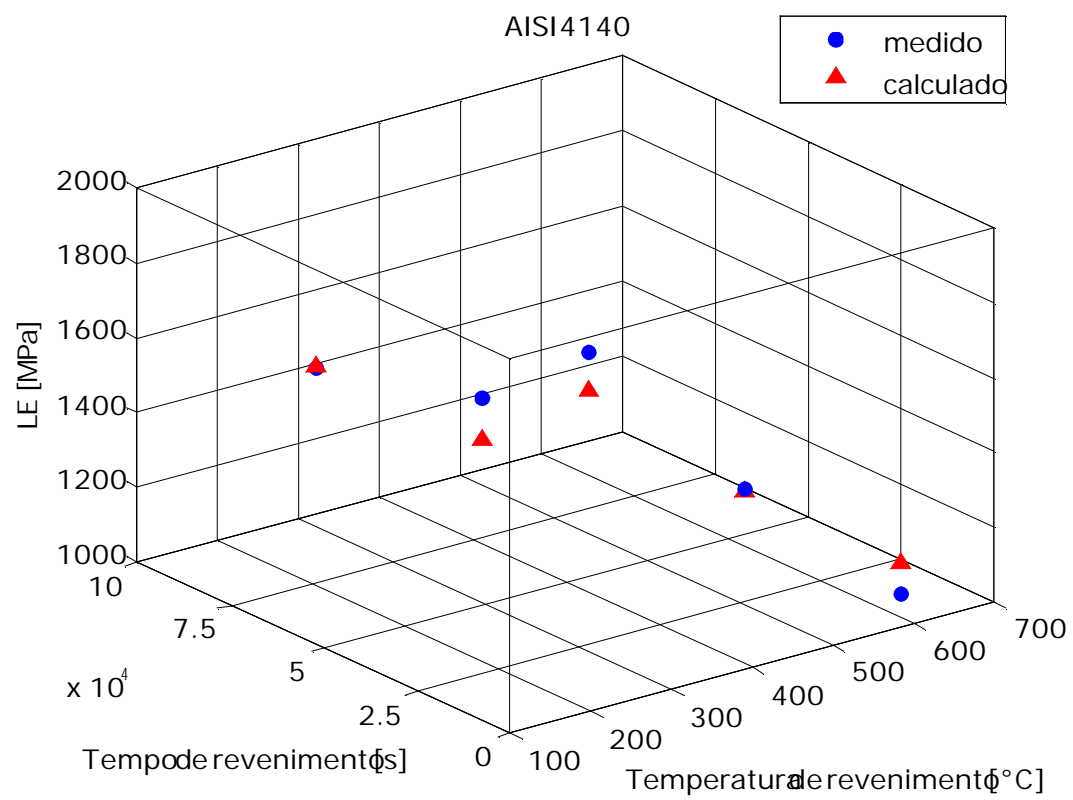

Figura 90: Comparação dos resultados calculados pela RNA com os valores medidos para o LE obtido pelo conjunto de teste do aço AISI 4140.

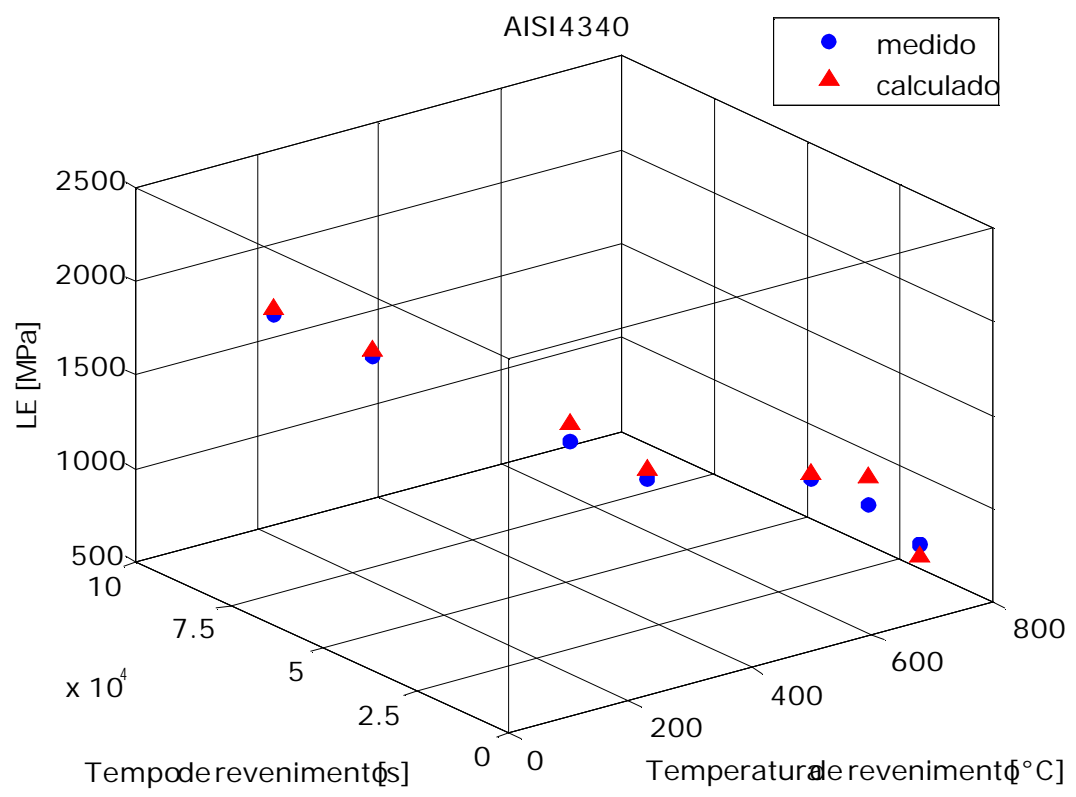

Figura 91: Comparação dos resultados calculados pela RNA com os valores medidos para o LE obtido pelo conjunto de teste do aço AISI 4340. 


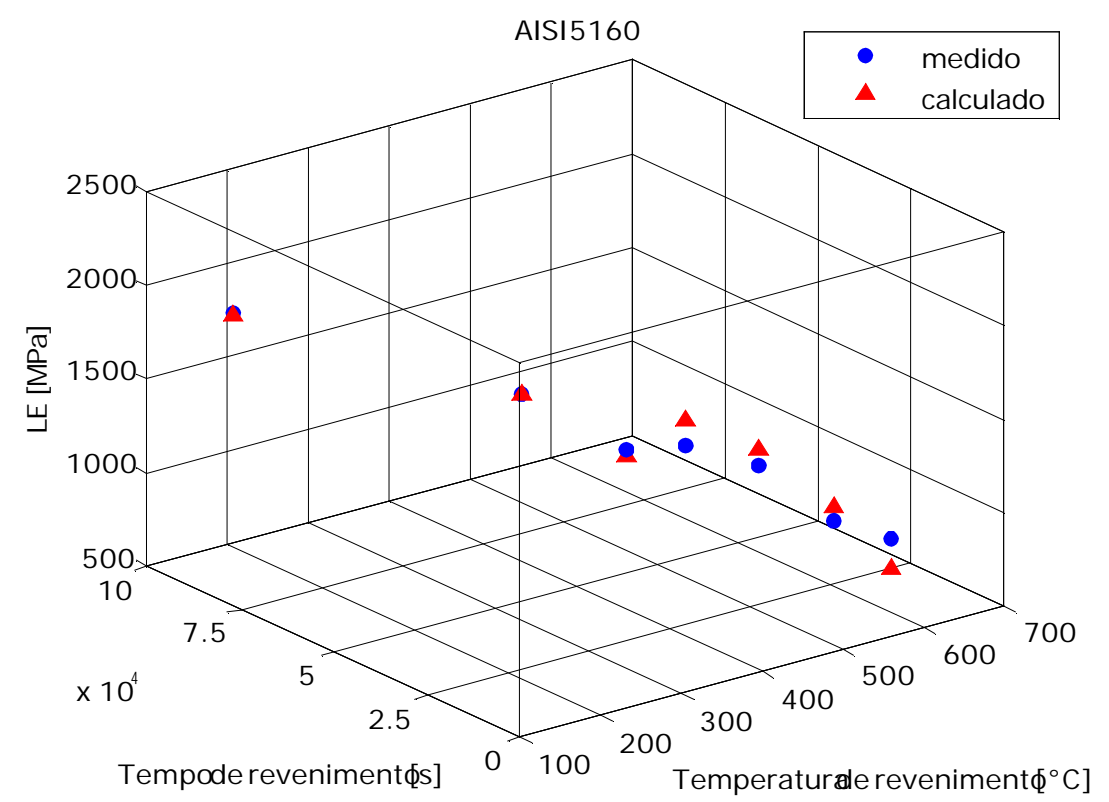

Figura 92: Comparação dos resultados calculados pela RNA com os valores medidos para o LE obtido pelo conjunto de teste do aço AISI 5160.

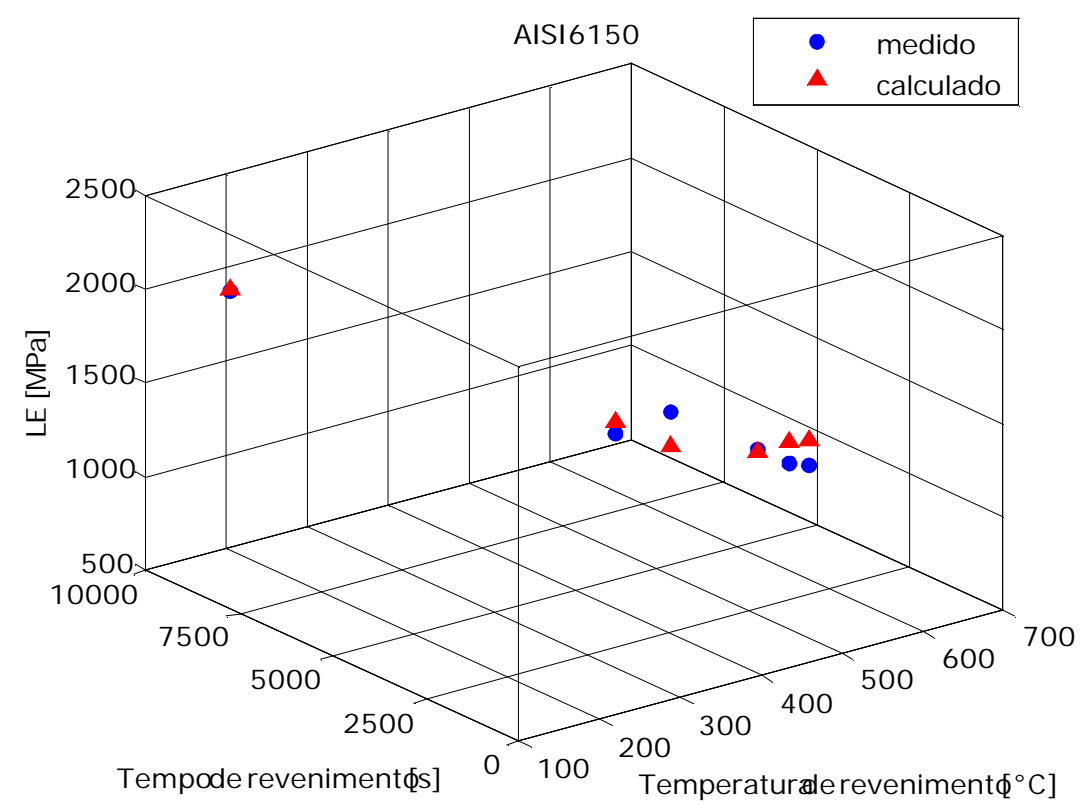

Figura 93: Comparação dos resultados calculados pela RNA com os valores medidos para o LE obtido pelo conjunto de teste do aço AISI 6150. 


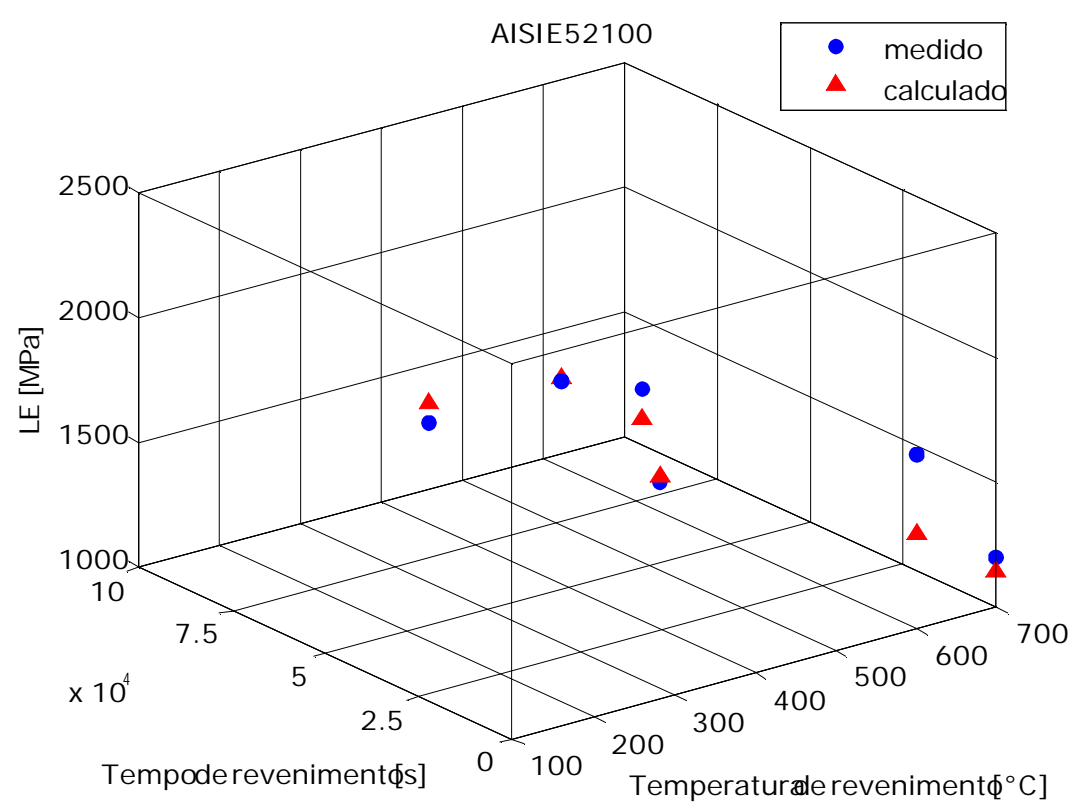

Figura 94: Comparação dos resultados calculados pela RNA com os valores medidos para o LE obtido pelo conjunto de teste do aço AISI E52100.

\subsubsection{Tensão de ruptura}

A base de dados utilizada para construir a RNA para calcular a tensão de ruptura consistiu apenas dos dados obtidos experimentalmente na seção 4.1.2. As estatísticas de suas variáveis de entrada podem ser observadas na Tabela 24.

Tabela 24: Variáveis de entrada da rede projetada para modelar a tensão de ruptura, o módulo de resiliência e o módulo de elasticidade.

\begin{tabular}{lcccc}
\hline Variáveis de entrada & Min. & Max. & Média & Desvio Padrão \\
\hline Temperatura [으 & 99 & 703 & 437 & 179 \\
Tempo [s] & 10 & 3600000 & 153600 & 64538 \\
$\% \mathrm{C}$ & 0,39 & 1,02 & 0,537 & 0,200 \\
$\% \mathrm{Mn}$ & 0,40 & 1,42 & 0,784 & 0,261 \\
$\% \mathrm{P}$ & 0 & 0,024 & 0,017 & 0,006 \\
$\% \mathrm{~S}$ & 0 & 0,019 & 0,014 & 0,005 \\
$\% \mathrm{Si}$ & 0,22 & 1,54 & 0,361 & 0,357 \\
$\% \mathrm{Ni}$ & 0 & 1,74 & 0,217 & 0,576 \\
$\% \mathrm{Cr}$ & 0,04 & 1,42 & 0,813 & 0,402 \\
$\% \mathrm{Mo}$ & 0 & 0,26 & 0,076 & 0,105 \\
\hline
\end{tabular}

Devido ao tamanho reduzido da amostra e principalmente a complexidade do problema, foi preciso reduzir o número de parâmetros da rede, diminuindo a 
quantidade das variáveis de entrada. Para isto foi aplicada a técnica da análise dos componentes principais que eliminou as variáveis de entrada que contribuíram em menos de 4\% na variação total do grupo de entrada. Desta forma a rede passou a contar com 6 variáveis de entrada como mostra a Figura 95.

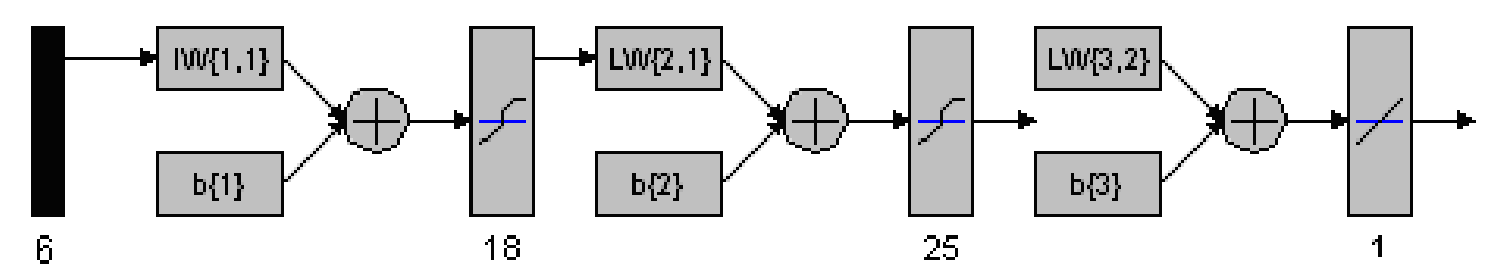

Figura 95: Arquitetura da rede neural proposta para calcular a tensão de ruptura.

O conjunto de treinamento correspondia a $92 \%$ do total de amostras e o gupo para teste aos $8 \%$ restantes. O treinamento foi realiza seguindo o algoritmo LM modificado por 302 iterações apresentando um erro final igual a 2,57 MPa. A Figura 96 mostra o decaimento do erro durante o treinamento. A Figura 97 mostra 0 comportamento da soma dos pesos quadráticos durante o treinamento. A Figura 98 traz os parâmetros utilizados para reduzir o erro em cada época.

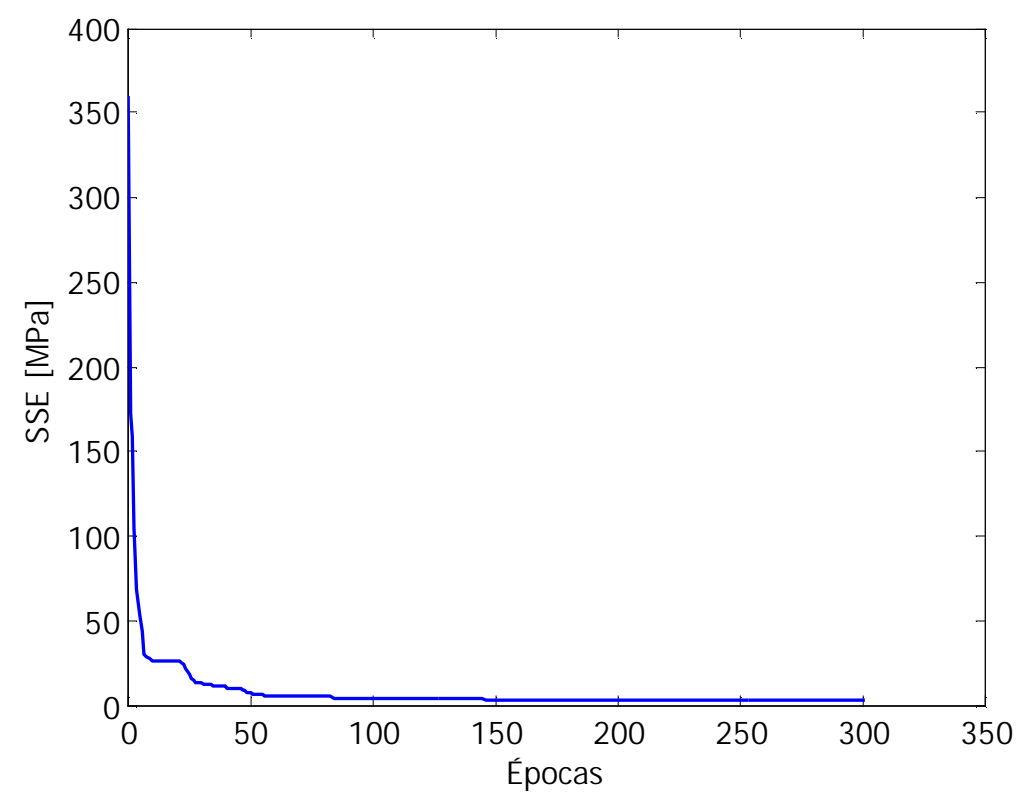

Figura 96: Decaimento do erro durante o treinamento da RNA construída para calcular a tensão de ruptura. 


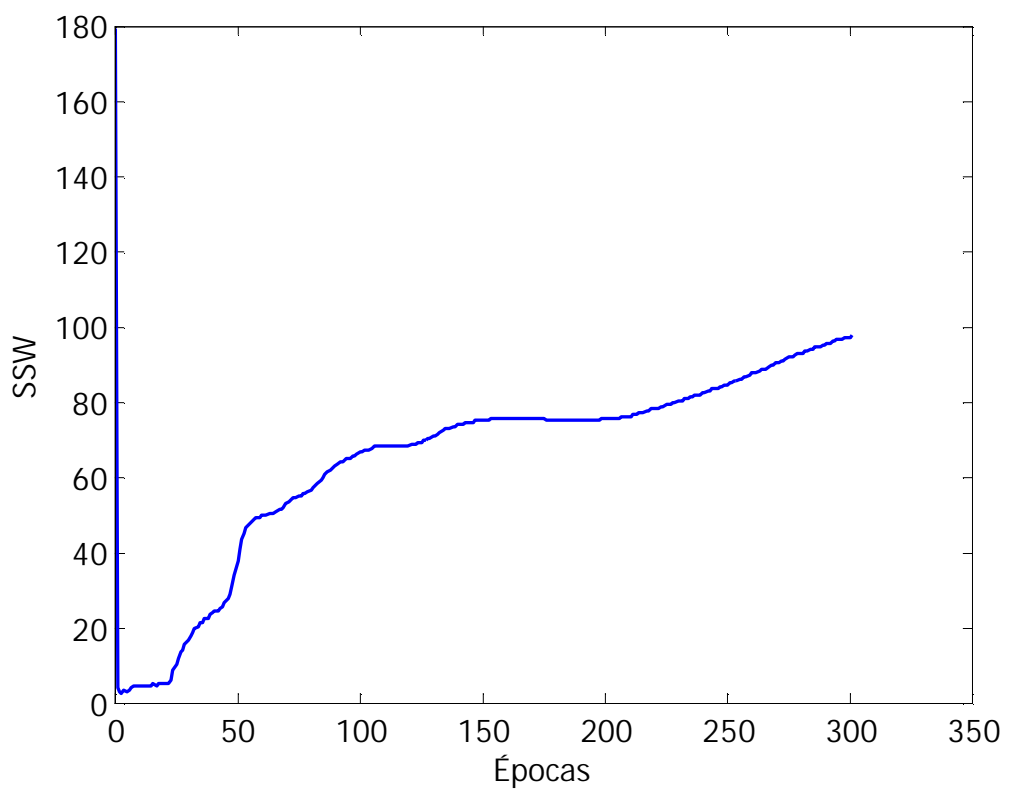

Figura 97: Soma dos pesos quadráticos durante o treinamento da RNA construída para calcular a tensão de ruptura.

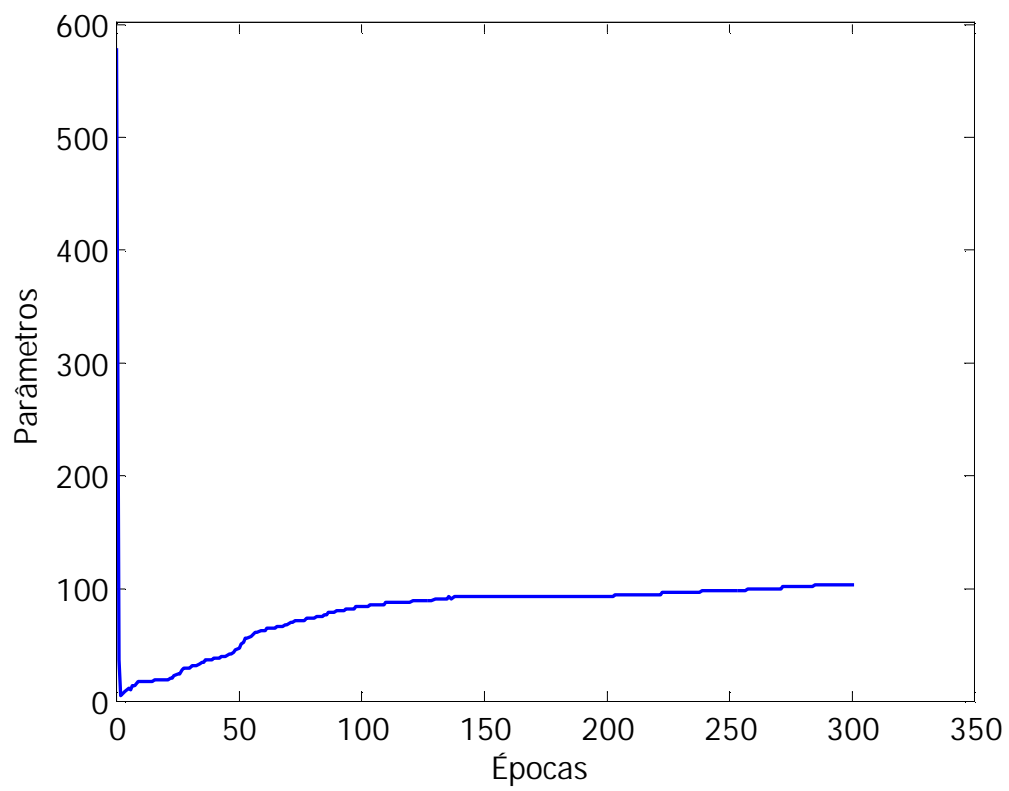

Figura 98: Parâmetros efetivamente utilizados durante o treinamento da RNA construída para calcular a tensão de ruptura.

As Figuras 99 e 100 trazem a análise de regressão linear para os conjuntos de treinamento e teste respectivamente. Os dados medidos e desejados do treinamento 
produziram um coeficiente de correlação igual a 0,993 e as amostras do conjunto de teste geraram $R=0,983$, mais uma vez indicando um bom ajuste linear.

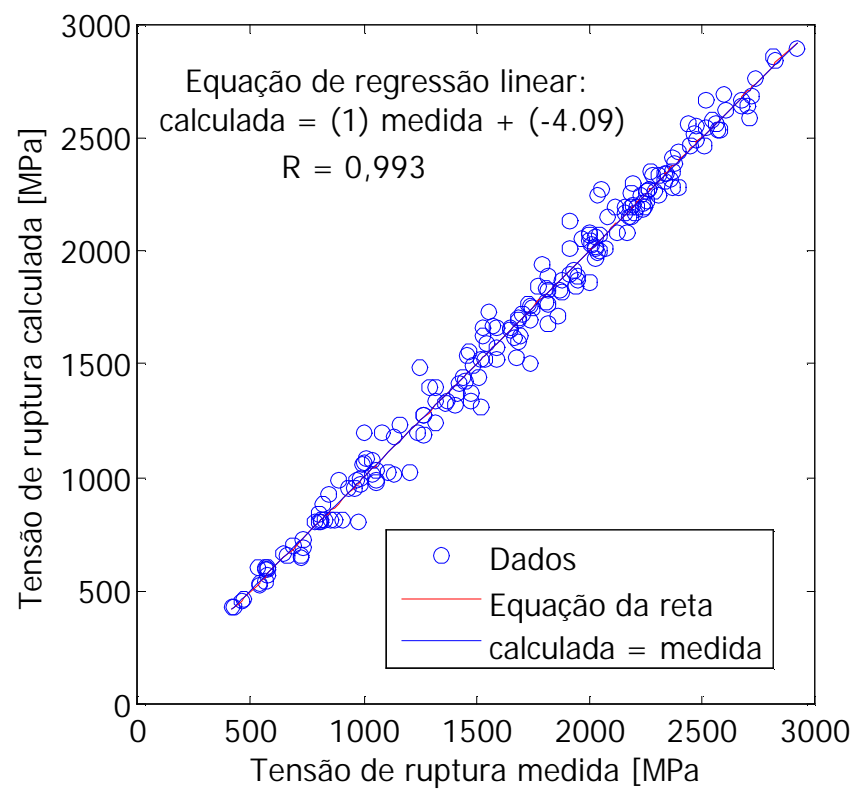

Figura 99: Correlação entre a $\sigma_{r}$ medida e a $\sigma_{r}$ calculada pela RNA para o conjunto de treinamento.

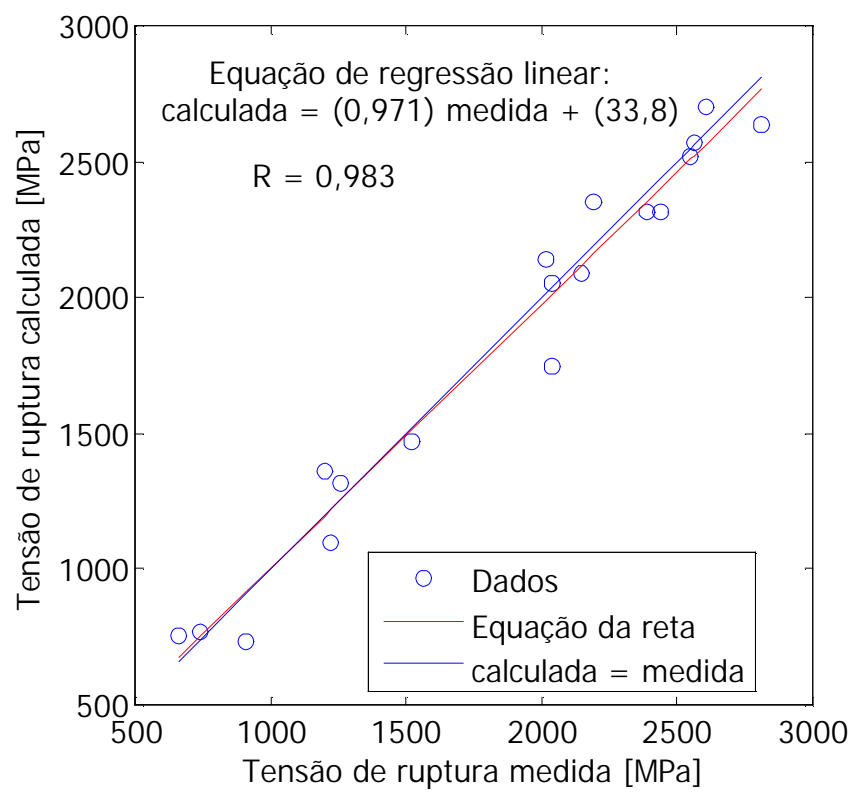

Figura 100: Correlação entre a $\sigma_{r}$ medida e a $\sigma_{r}$ calculada pela RNA para o conjunto de teste. 
$\mathrm{O}$ resultado do teste t-student pode ser visto na Tabela 25 , onde $\mathrm{H}=0$ indica que a hipótese nula é verdadeira com $93 \%$ de confiança e, portanto o modelo pode ser validado para este nível de confiança.

Tabela 25: Teste T-student para o conjunto de teste da $\sigma_{\mathrm{r}}$.

\begin{tabular}{ccccc}
\hline Graus de liberdade & $\mathrm{H}$ & Intervalo de confiança & $\mathrm{t}$ & confiança \\
\hline 34 & 0 & $(-490,37 ; 449,84)$ & $-0,0876$ & $93,07 \%$ \\
\hline
\end{tabular}

As Figuras 101, 102, 103, 104 e 105 mostram os valores obtidos experimentalmente e pela RNA para o conjunto de teste de cada aço testado. 0 que se nota em um melhor ajuste para os aços AISI 4140, 4340 e 5160. 0 pior ajuste aconteceu para o aço AISI E52100, talvez este fato possa ser atribuído ao conjunto de treinamento, pois este material é o que mais se difere dos outros em relação à composição química e, portanto pode-se deduzir que tenham faltado exemplos no treinamento.

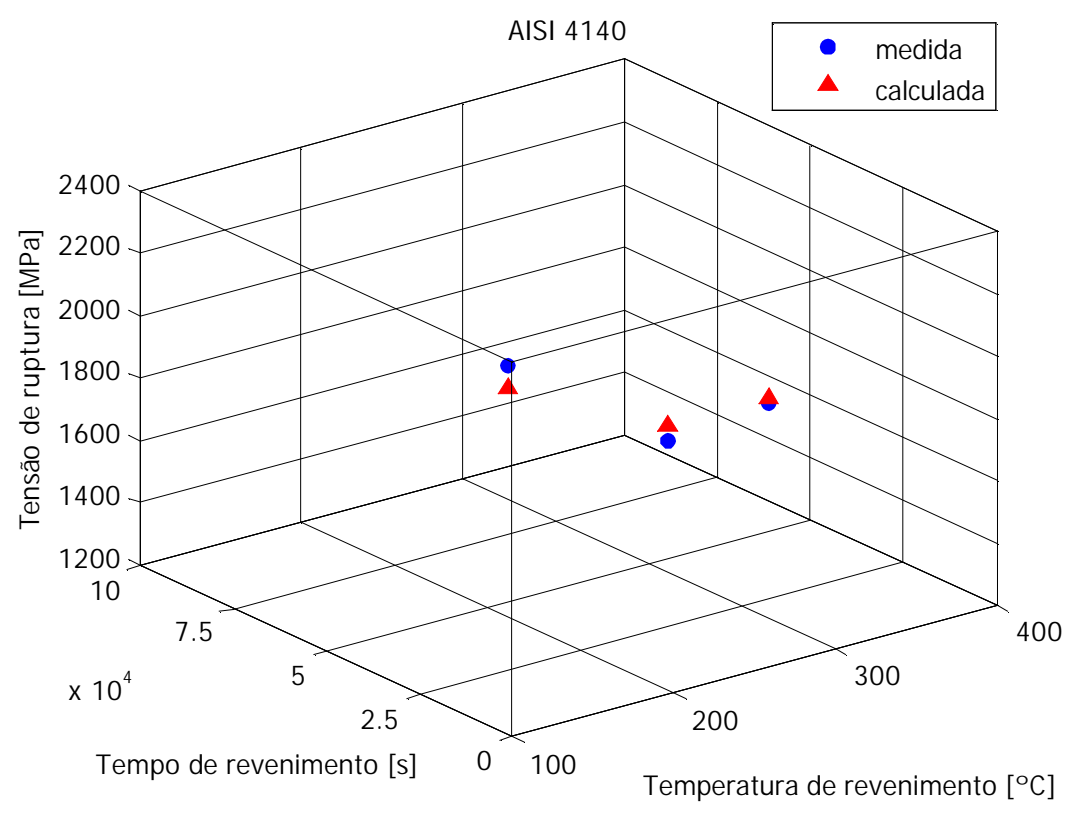

Figura 101: Comparação dos resultados calculados pela RNA com os valores medidos para a $\sigma_{r}$ obtido pelo conjunto de teste do aço AISI 4140. 


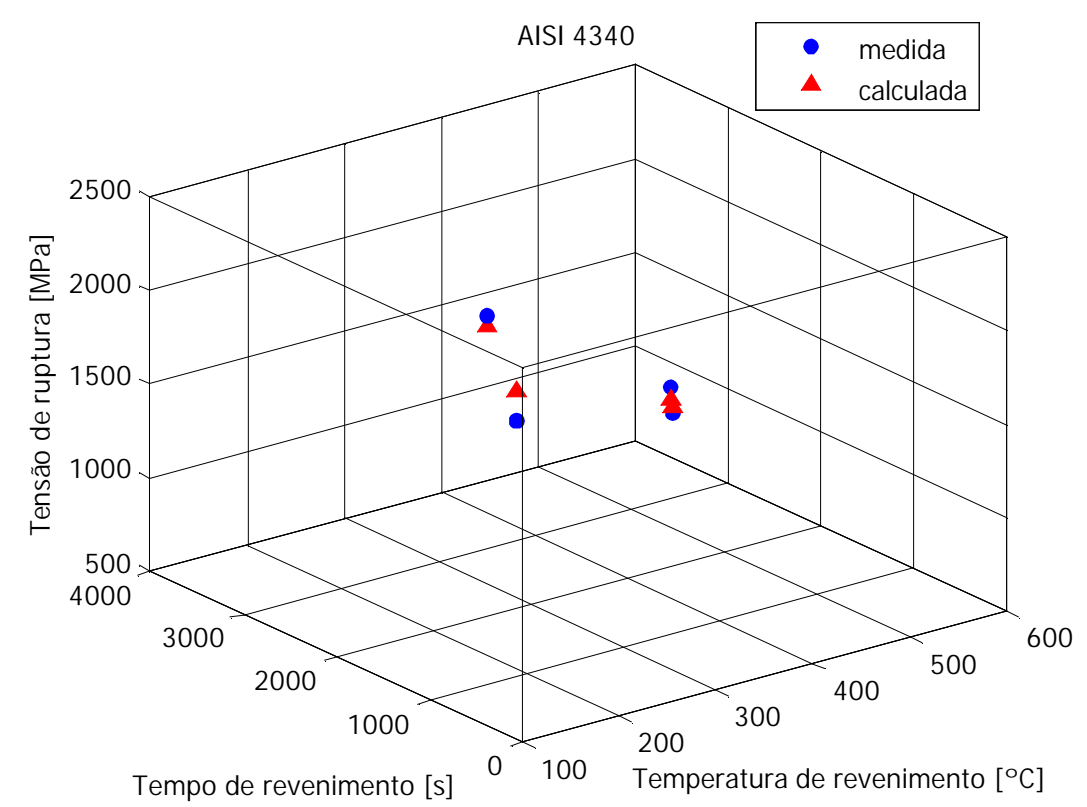

Figura 102: Comparação dos resultados calculados pela RNA com os valores medidos para a $\sigma_{\mathrm{r}}$ obtido pelo conjunto de teste do aço AISI 4340.

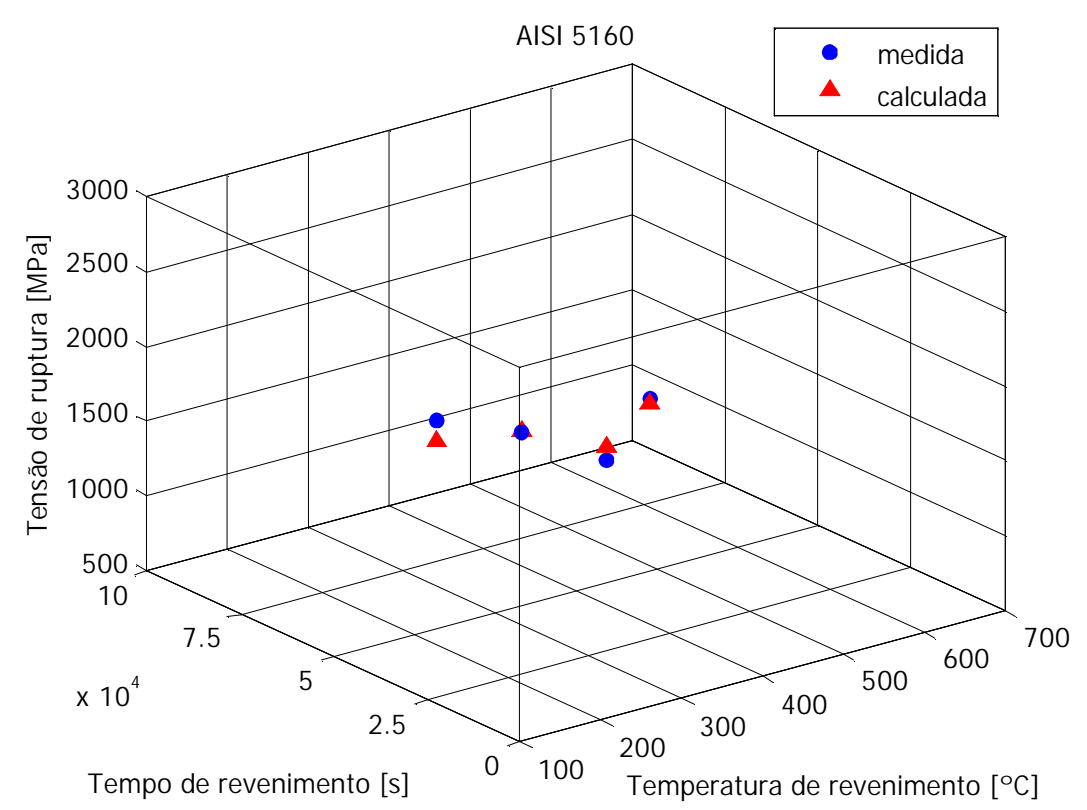

Figura 103: Comparação dos resultados calculados pela RNA com os valores medidos para a $\sigma_{\mathrm{r}}$ obtido pelo conjunto de teste do aço AISI 5160. 


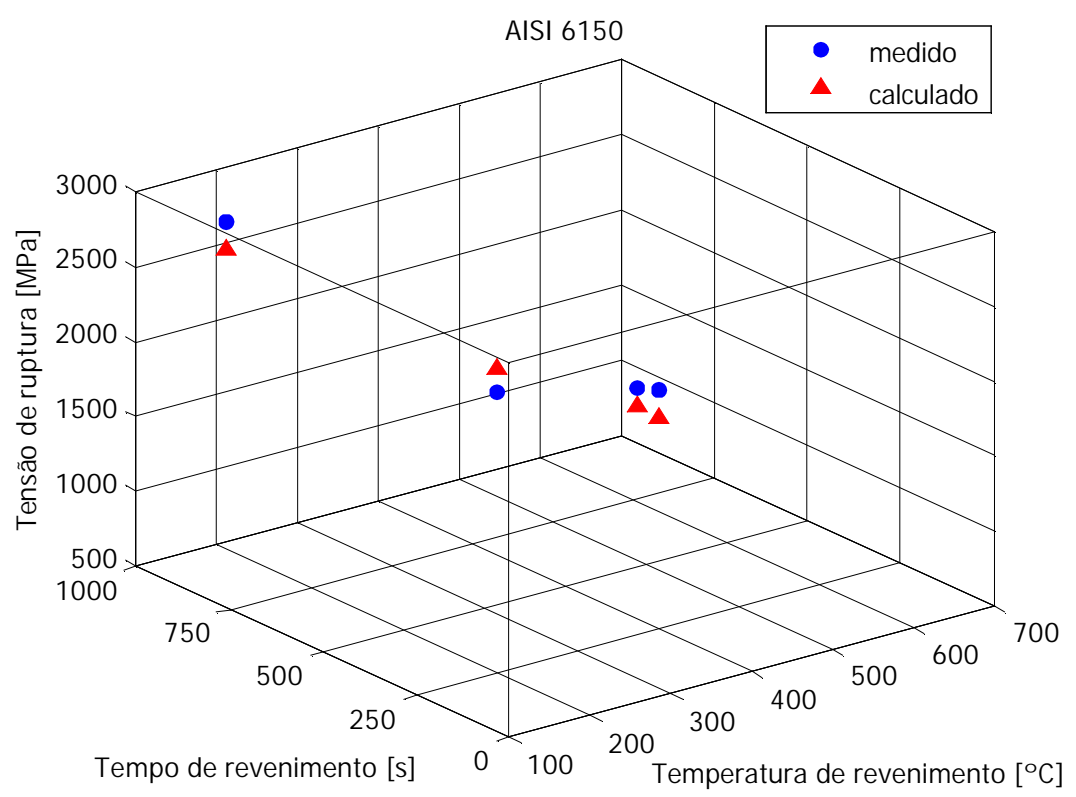

Figura 104: Comparação dos resultados calculados pela RNA com os valores medidos para a $\sigma_{\mathrm{r}}$ obtido pelo conjunto de teste do aço AISI 6150.

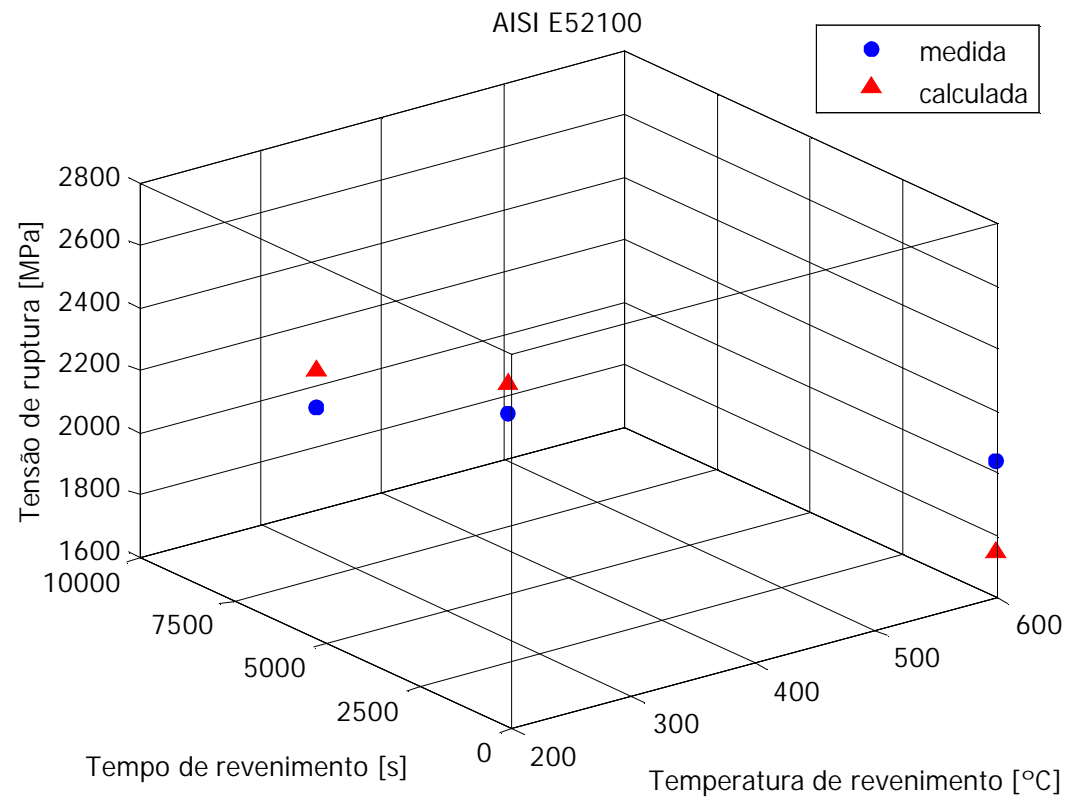

Figura 105: Comparação dos resultados calculados pela RNA com os valores medidos para a $\sigma_{r}$ obtido pelo conjunto de teste do aço AISI E52100. 


\subsubsection{Módulo de resiliência}

O conjunto de dados utilizados para modelar o módulo de resiliência foi 0 mesmo utilizado para o cálculo da tensão de ruptura e corresponde aos dados obtidos experimentalmente na seção 4.1.2. 0 conjunto de treinamento corresponde a $90 \%$ do total e o conjunto de teste aos $10 \%$ restantes. De forma análoga à seção anterior, foi necessário reduzir o tamanho da entrada da rede pela aplicação da análise dos componentes principais que eliminou 4 variáveis de entrada. As informações referentes à média, valores mínimo e máximo de cada variável pode ser observada na Tabela 24. A rede utilizada pode ser vista na Figura 106.

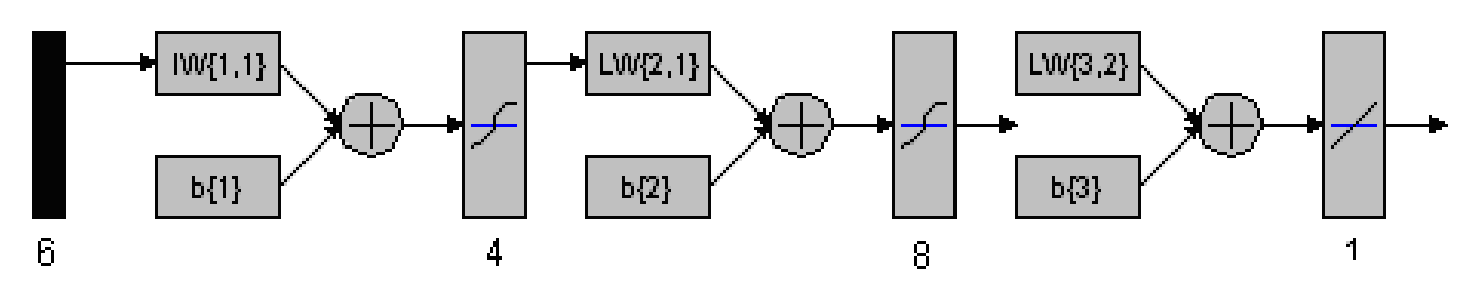

Figura 106: RNA com 6 variáveis de entrada e duas camadas ocultas com 4 e 8 neurônios.

O valor da soma dos erros quadráticos era igual a $3 \mathrm{~kJ} / \mathrm{m}^{3}$ após 305 épocas quando algoritmo atingiu o valor máximo de $\mu$ e interrompeu o treinamento. A Figura 107 ilustra decaimento do erro e as Figuras 108 e 109 ilustram a soma dos pesos quadráticos e os parâmetros utilizados durante o treinamento respectivamente. Através da Figura 109 pode-se notar que a rede era grande o suficiente para ajustar os dados. 


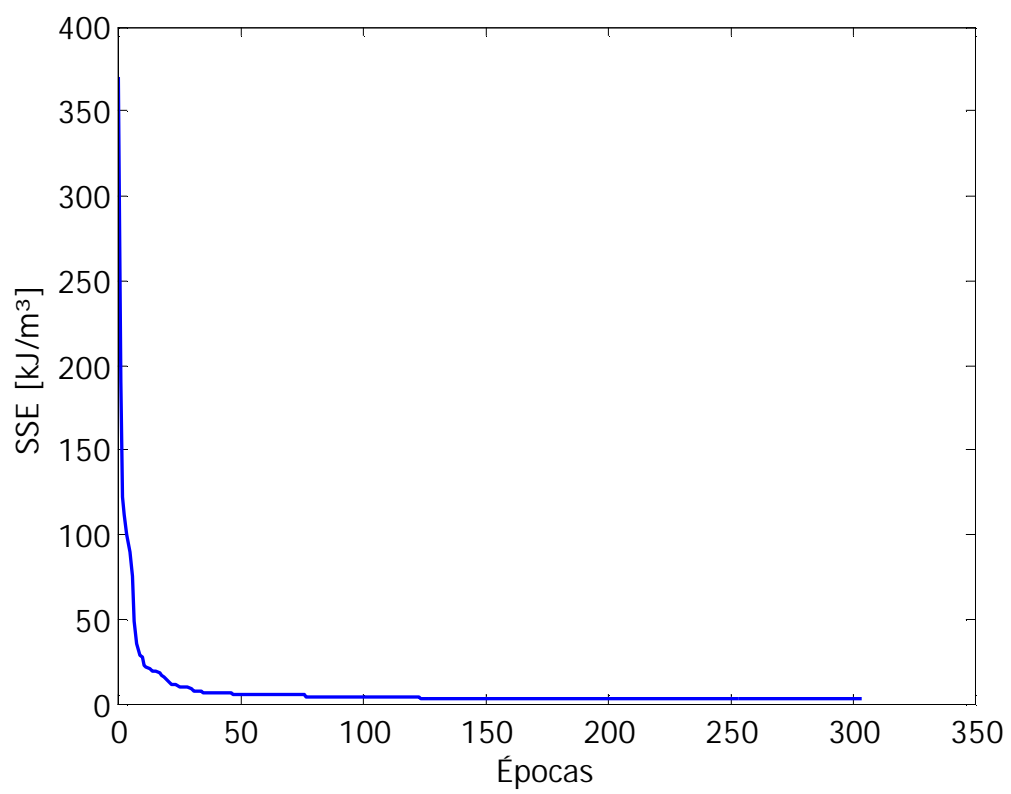

Figura 107: Decaimento do erro durante o treinamento da RNA construída para calcular o módulo de resiliência.

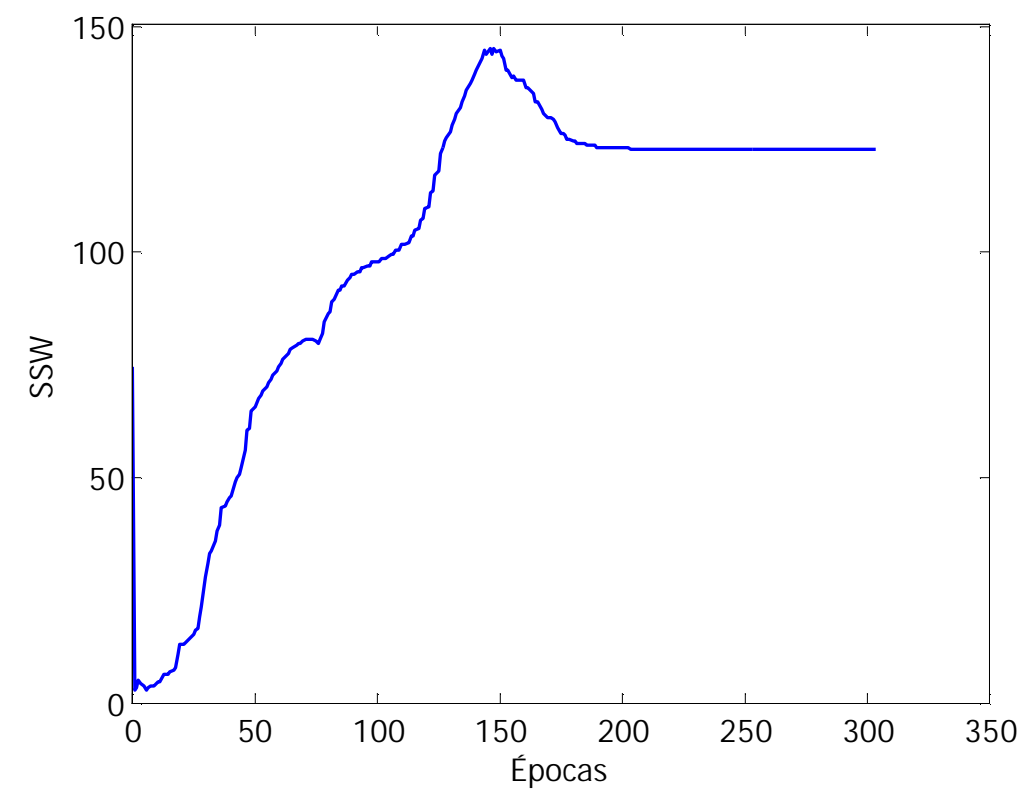

Figura 108: Soma dos pesos quadráticos durante o treinamento da RNA construída para calcular o módulo de resiliência. 


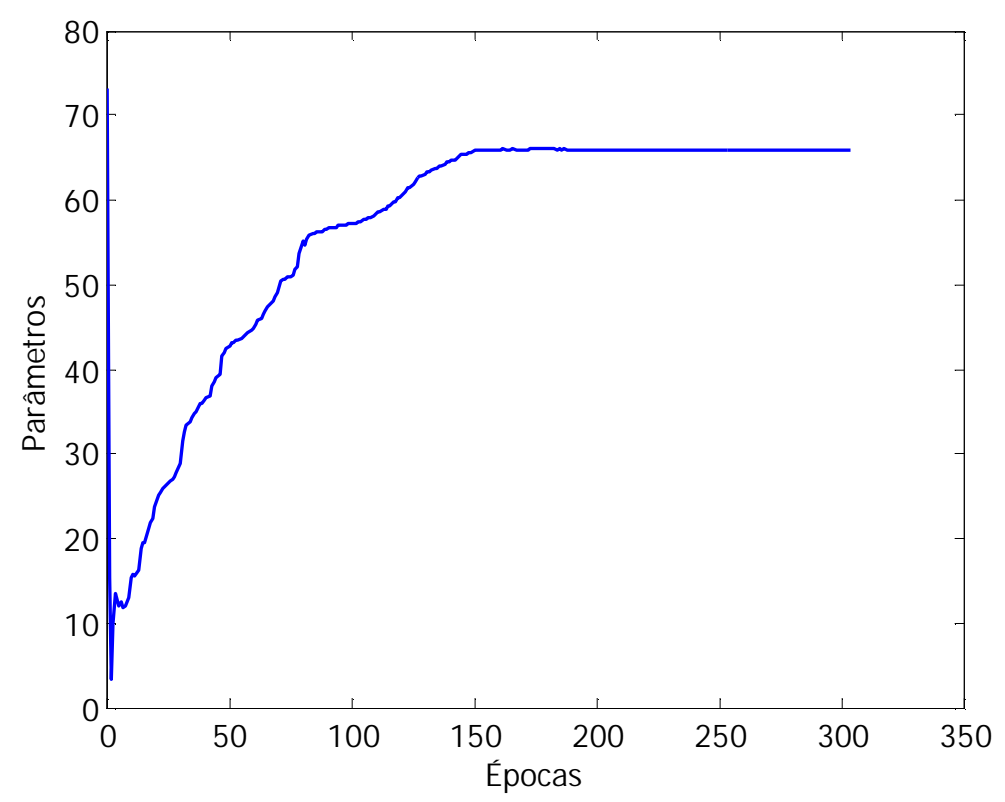

Figura 109: Parâmetros efetivamente utilizados durante o treinamento da RNA construída para calcular o módulo de resiliência.

A regressão linear para o conjunto de treinamento e de teste pode ser analisada nas Figuras 110 e 111 respectivamente. 0 que se nota nestas figuras é o bom ajuste linear assim como um excelente coeficiente de correlação para os dois casos $(R=0,992$ para o treinamento e $R=0,983$ para o teste).

$\mathrm{O}$ resultado do teste t-student pode ser visto na Tabela 26, onde $\mathrm{H}=0$ indica que a hipótese nula é verdadeira com $92 \%$ de confiança e, portanto pode-se validar o modelo para este nível de significância.

Tabela 26: Teste T-student para o conjunto de teste do $U_{r}$.

\begin{tabular}{ccccc}
\hline $\begin{array}{c}\text { Graus de } \\
\text { liberdade }\end{array}$ & $\mathrm{H}$ & $\begin{array}{c}\text { Intervalo de } \\
\text { confiança }\end{array}$ & $\mathrm{t}$ & Confiança \\
\hline 42 & 0 & $(-2,352 ; 2,118)$ & $-0,106$ & $92 \%$ \\
\hline
\end{tabular}




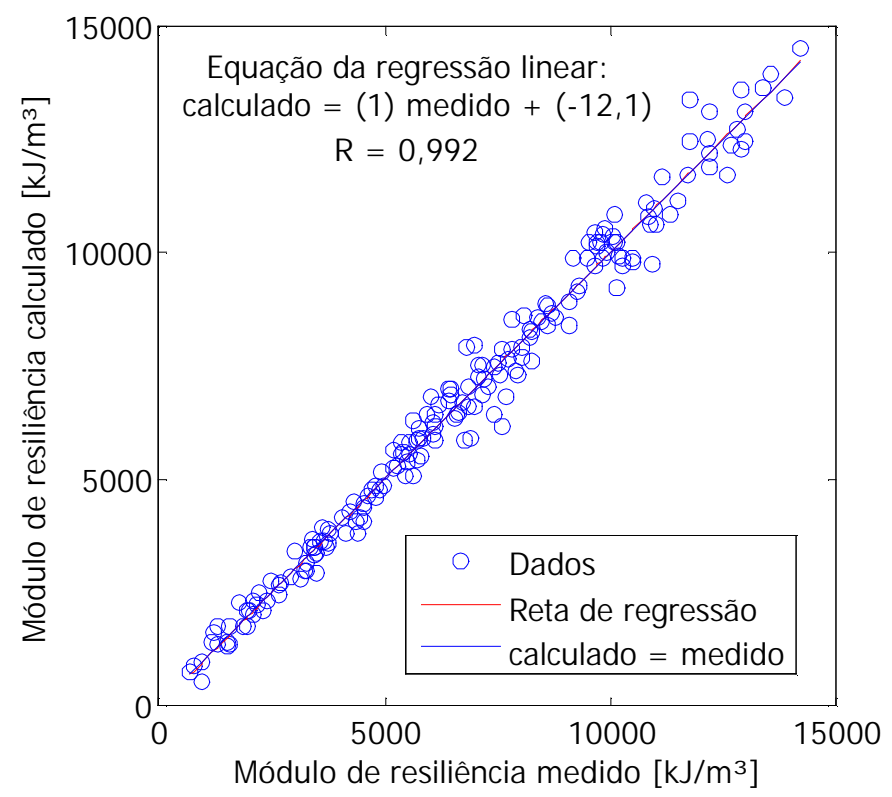

Figura 110: Correlação entre o $U_{r}$ medido e o $U_{r}$ calculado pela RNA para o conjunto de treinamento

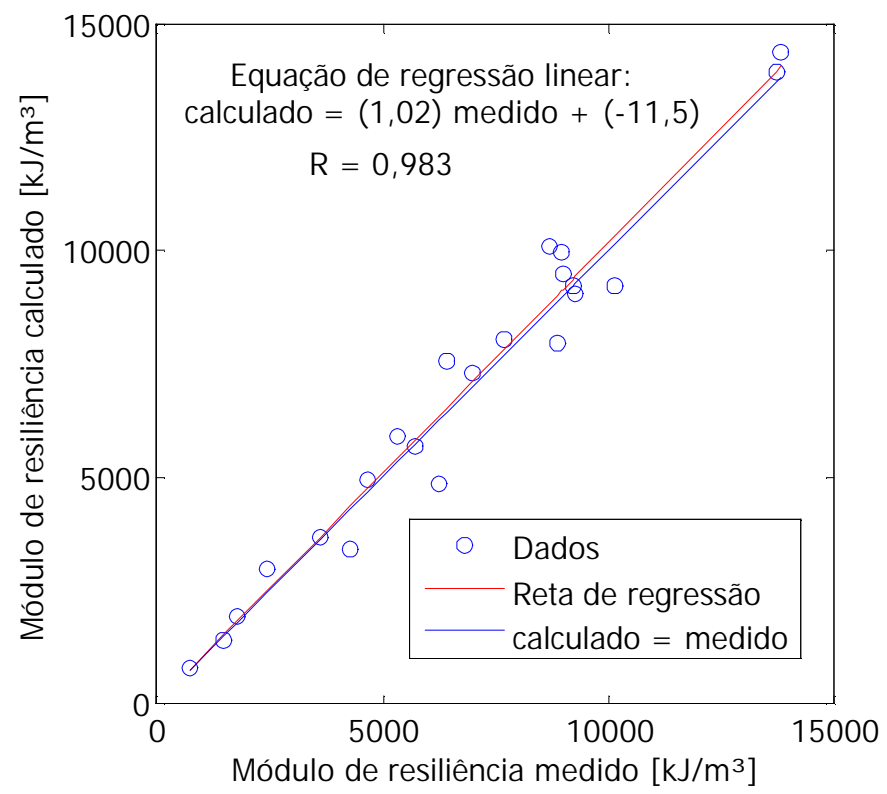

Figura 111: Correlação entre o $U_{r}$ medido e o $U_{r}$ calculado pela RNA para o conjunto de teste.

As Figuras 112, 113, 114, 115 e 116 mostram os valores experimentais e calculados pela RNA para os aços AISI 4140, 4340, 5160, 6150 e E52100 respectivamente. 


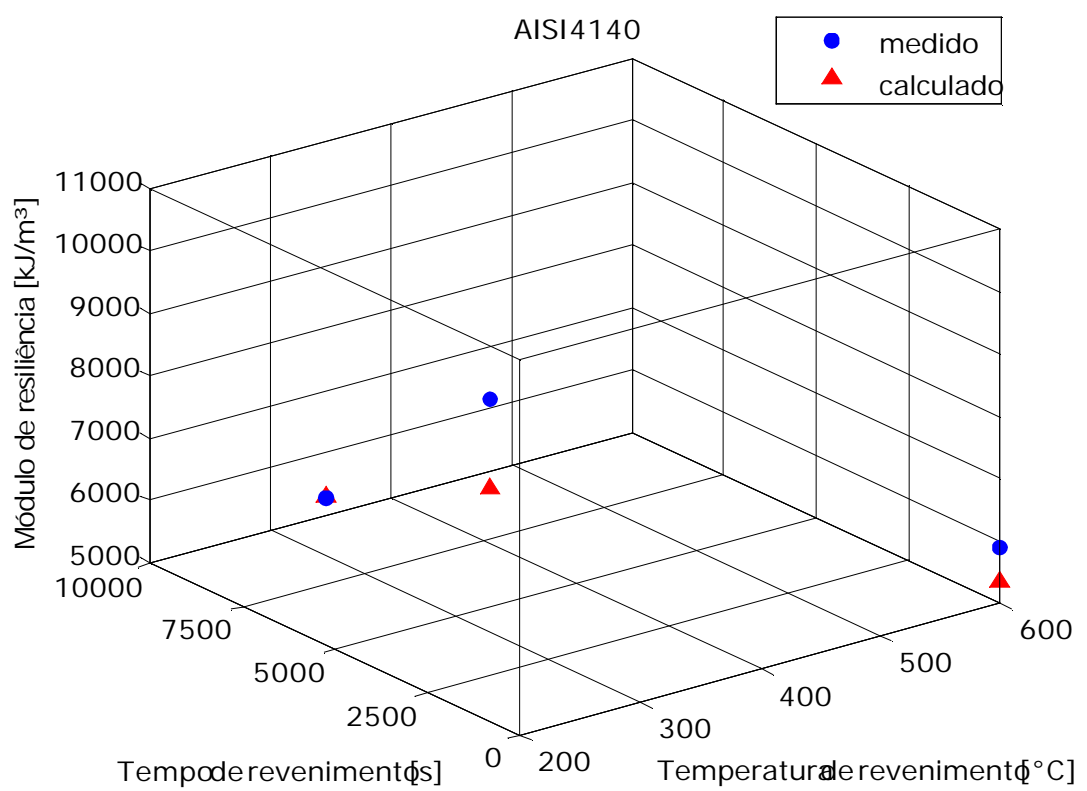

Figura 112: Comparação dos resultados calculados pela RNA com os valores medidos para o $U_{r}$ obtido pelo conjunto de teste do aço AISI 4140.

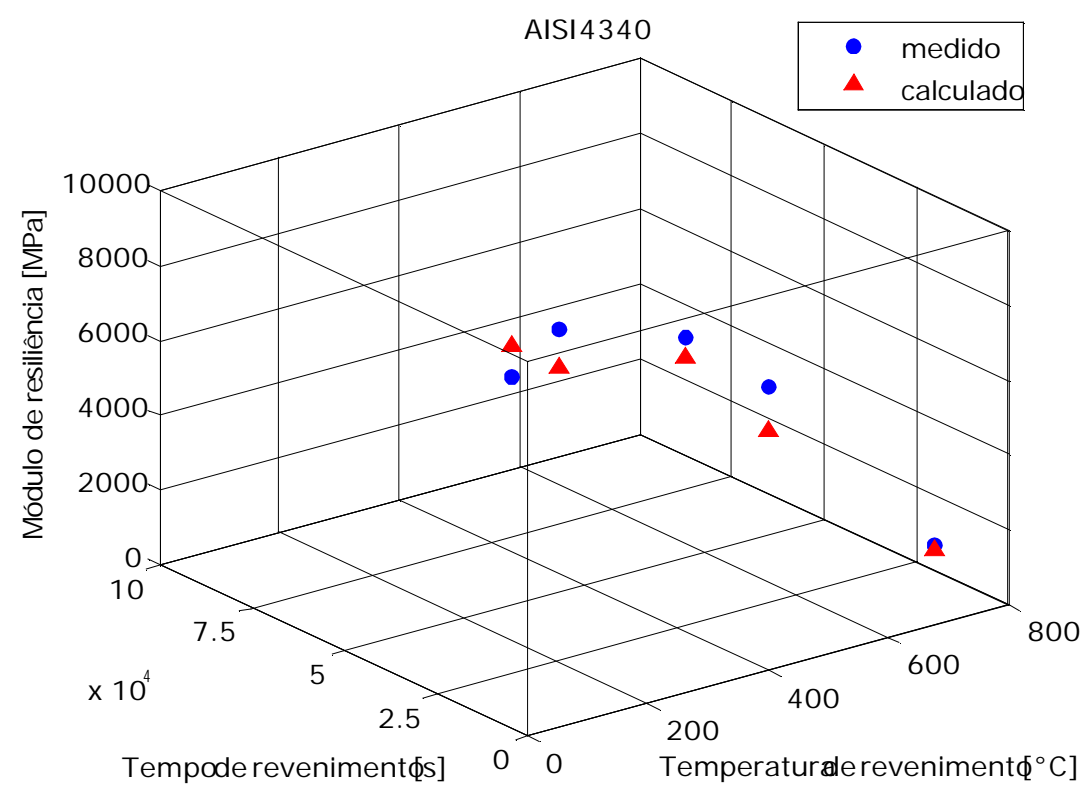

Figura 113: Comparação dos resultados calculados pela RNA com os valores medidos para o $U_{r}$ obtido pelo conjunto de teste do aço AISI 4340. 


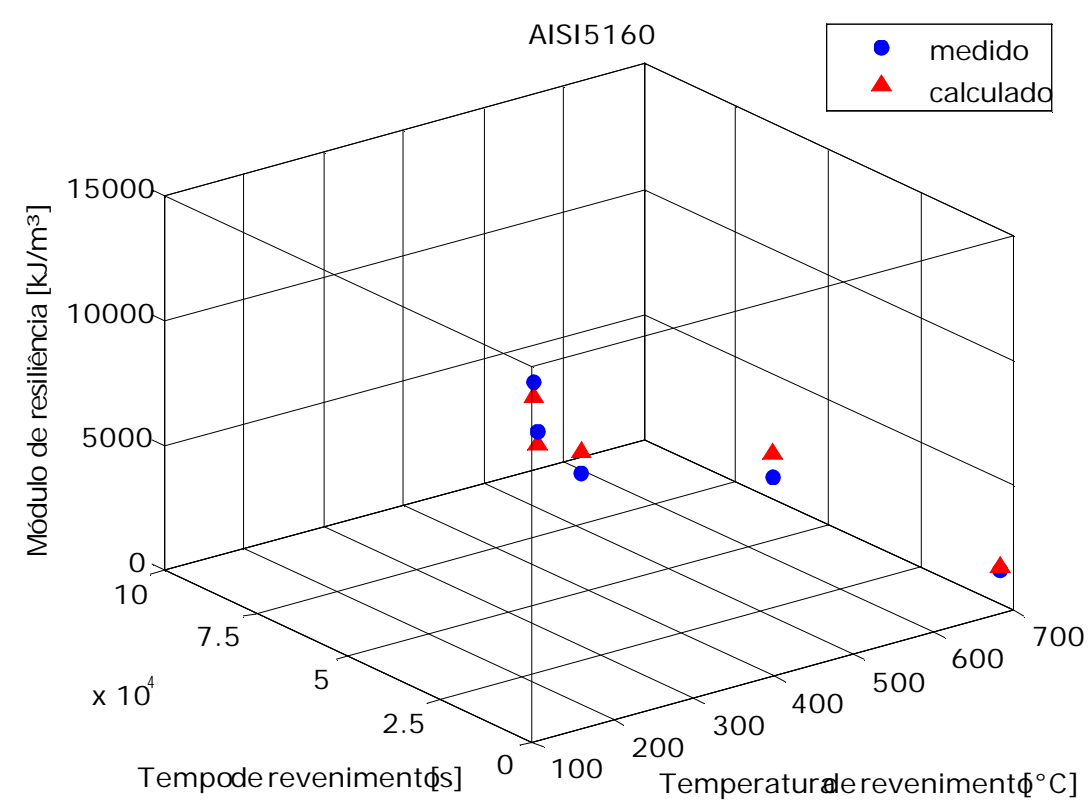

Figura 114: Comparação dos resultados calculados pela RNA com os valores medidos para o $U_{r}$ obtido pelo conjunto de teste do aço AISI 5160.

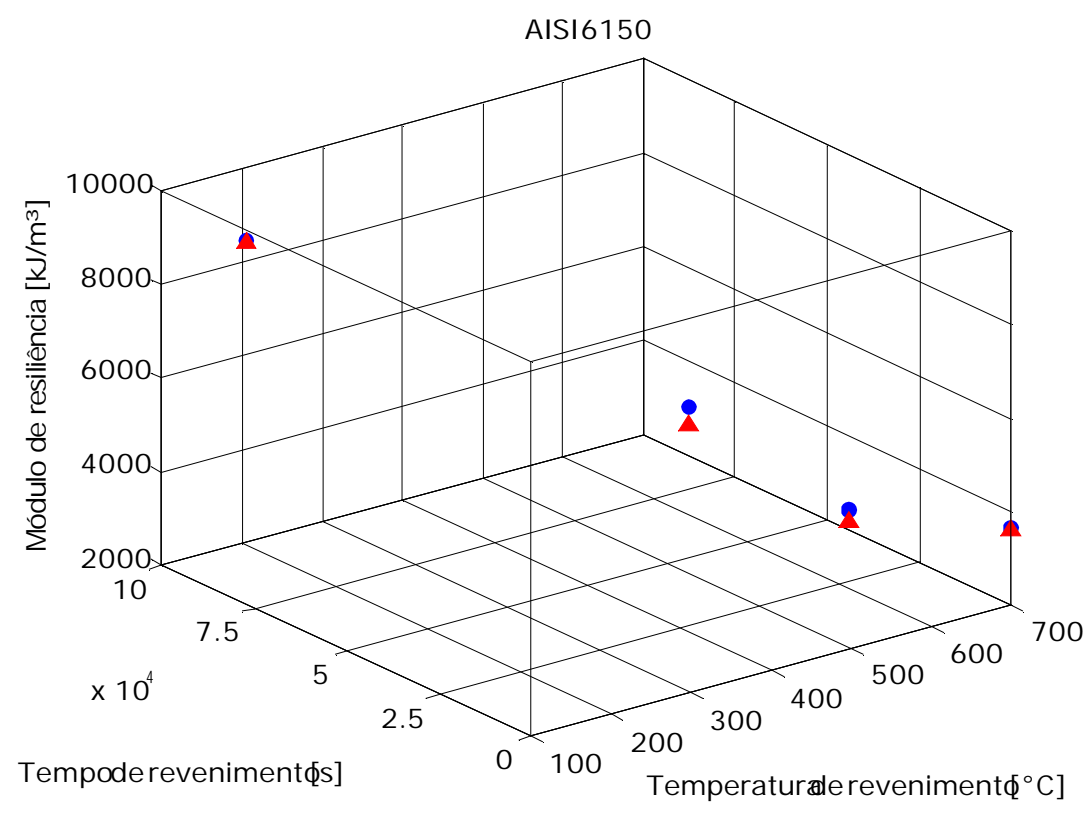

Figura 115: Comparação dos resultados calculados pela RNA com os valores medidos para o $U_{r}$ obtido pelo conjunto de teste do aço AISI 6150. 


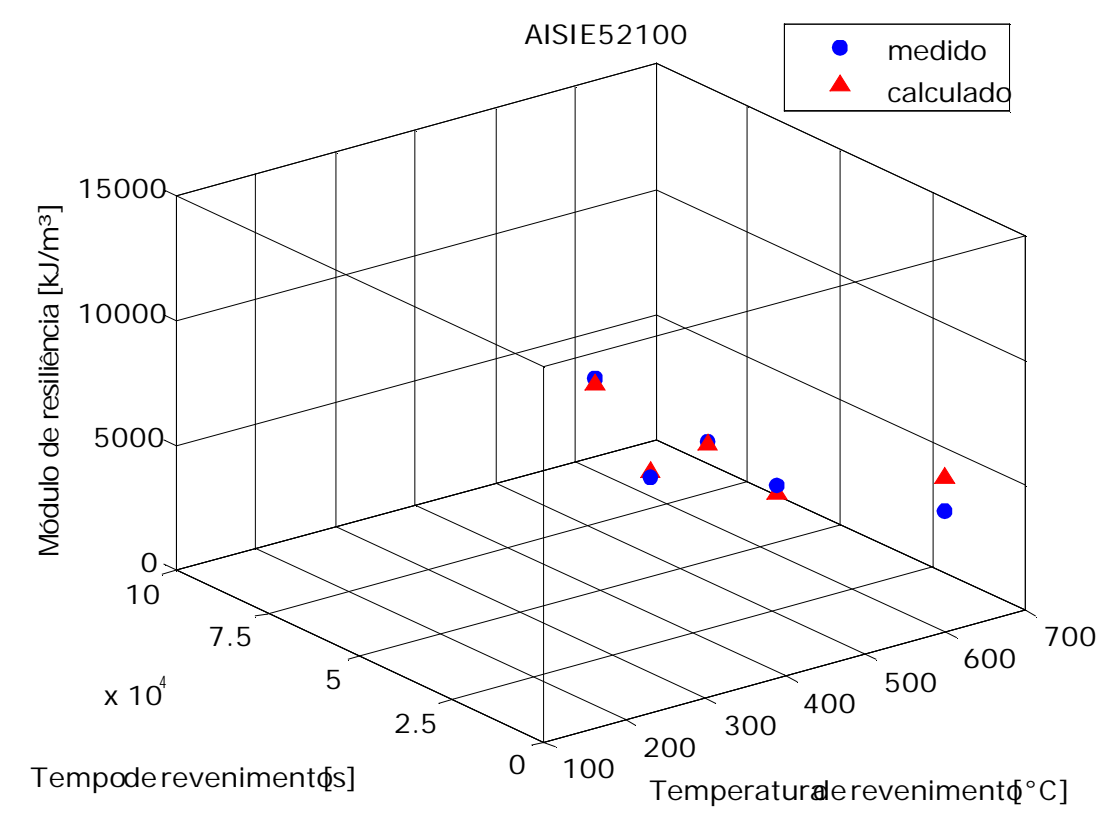

Figura 116: Comparação dos resultados calculados pela RNA com os valores medidos para o $\mathrm{U}_{\mathrm{r}}$ obtido pelo conjunto de teste do aço AISI E52100.

\subsubsection{Módulo de tenacidade}

O conjunto de dados utilizados para modelar o módulo de tenacidade foi 0 mesmo utilizado para o cálculo da tensão de ruptura e do módulo de tenacidade. De forma análoga à seção anterior, foi necessário reduzir o tamanho da entrada da rede pela aplicação da análise dos componentes principais que eliminou 4 variáveis de entrada. As informações referentes à média, valores mínimo e máximo de cada variável pode ser observada na Tabela 24. A rede utilizada pode ser vista na Figura 117.

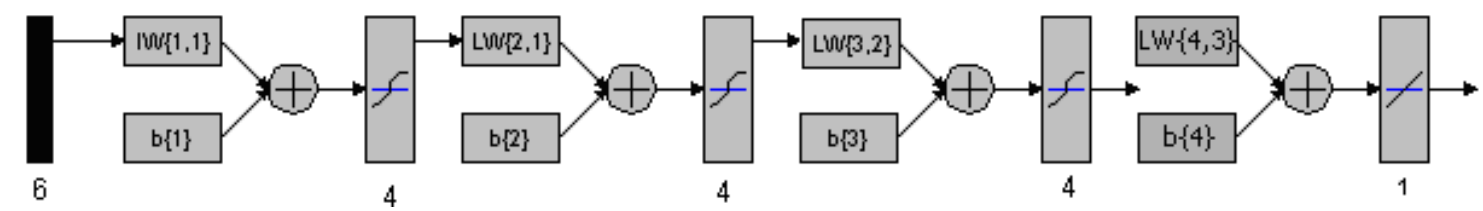

Figura 117: Arquitetura da rede utilizada para calcular o módulo de tenacidade.

O treinamento durou 213 iterações apresentando ao final do processo $\mathrm{SSE}=10,3$. O treinamento foi interrompido quando o algoritmo atingiu o valor 
máximo de $\mu$. As Figuras 118, 119 e 120 trazem o comportamento da SSE, da SSW e dos parâmetros durante $o$ treinamento.

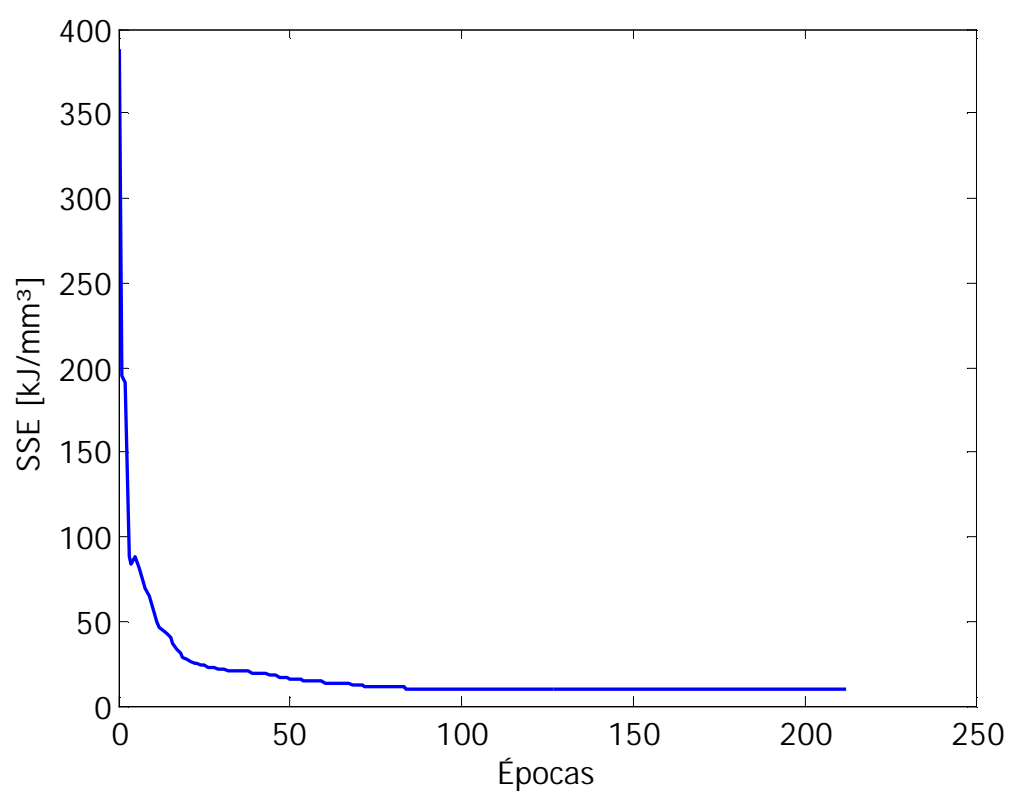

Figura 118: Decaimento do erro durante o treinamento da RNA construída para calcular o módulo de tenacidade.

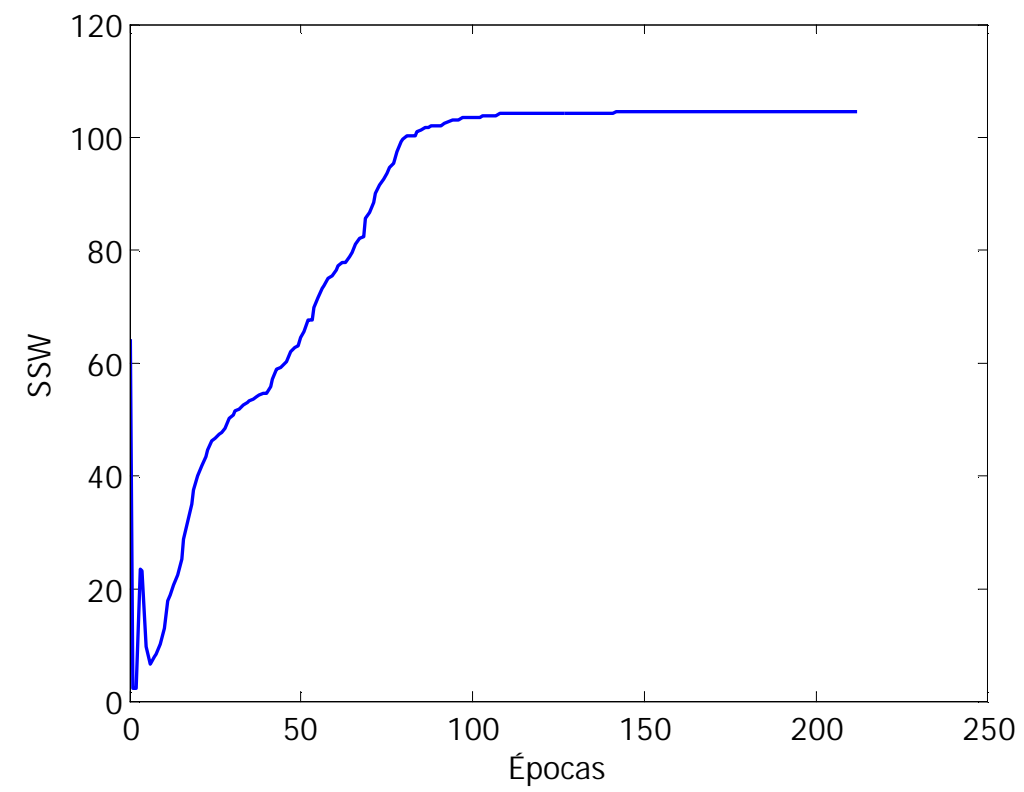

Figura 119: Decaimento do erro durante o treinamento da RNA construída para calcular o módulo de tenacidade. 


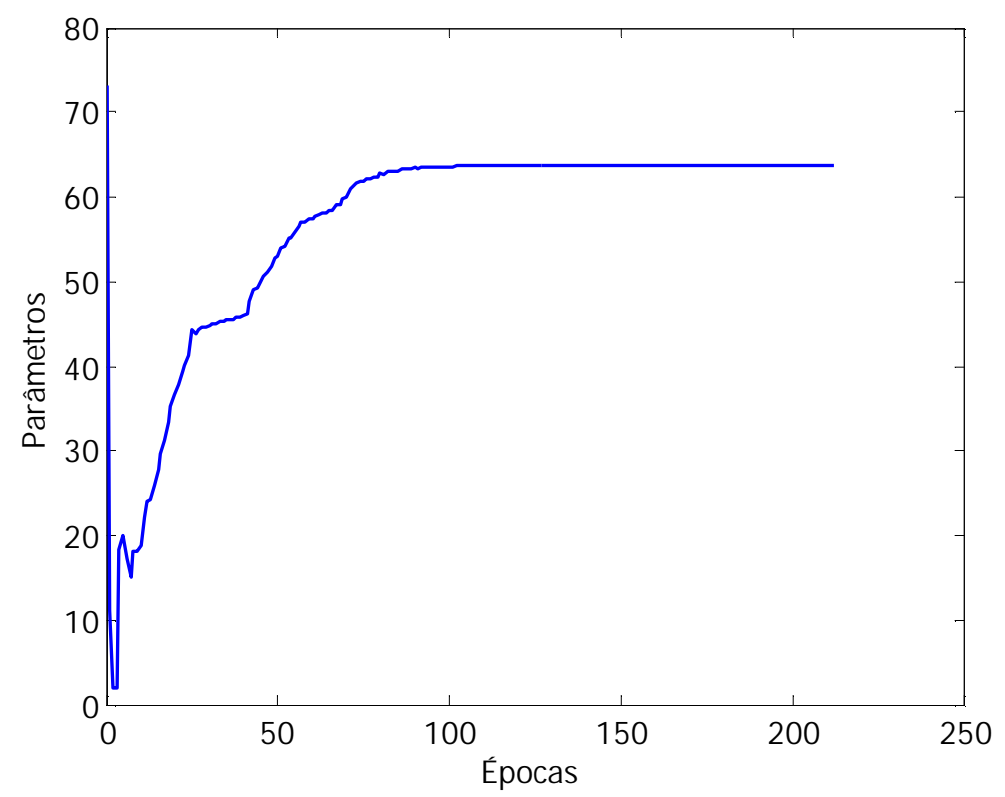

Figura 120: Decaimento do erro durante o treinamento da RNA construída para calcular o módulo de tenacidade.

As Figuras 121 e 122 mostram os resultados obtidos para a regressão linear para os conjuntos de treinamento e teste respectivamente. 0 coeficiente de correlação obtido nesta oportunidade foi inferior aos resultados obtidos até então. Para o conjunto de treinamento foi igual a 0,973 , e para o conjunto de teste 0,932 , indicando um ajuste razoável.

$\mathrm{O}$ resultado do teste t-student pode ser visto na Tabela 27, onde $\mathrm{H}=0$ indica que as médias das duas amostras são iguais com $97 \%$ de confiança e, portanto pode-se validar o modelo para este nível de significância.

Tabela 27: Teste T-student o conjunto de teste para $U_{t}$.

\begin{tabular}{ccccc}
\hline $\begin{array}{c}\text { Graus de } \\
\text { liberdade }\end{array}$ & $\mathrm{H}$ & $\begin{array}{c}\text { Intervalo de } \\
\text { confiança }\end{array}$ & $\mathrm{t}$ & Confiança \\
\hline 42 & 0 & $(-31,13,29,99)$ & $-0,0376$ & $97 \%$ \\
\hline
\end{tabular}




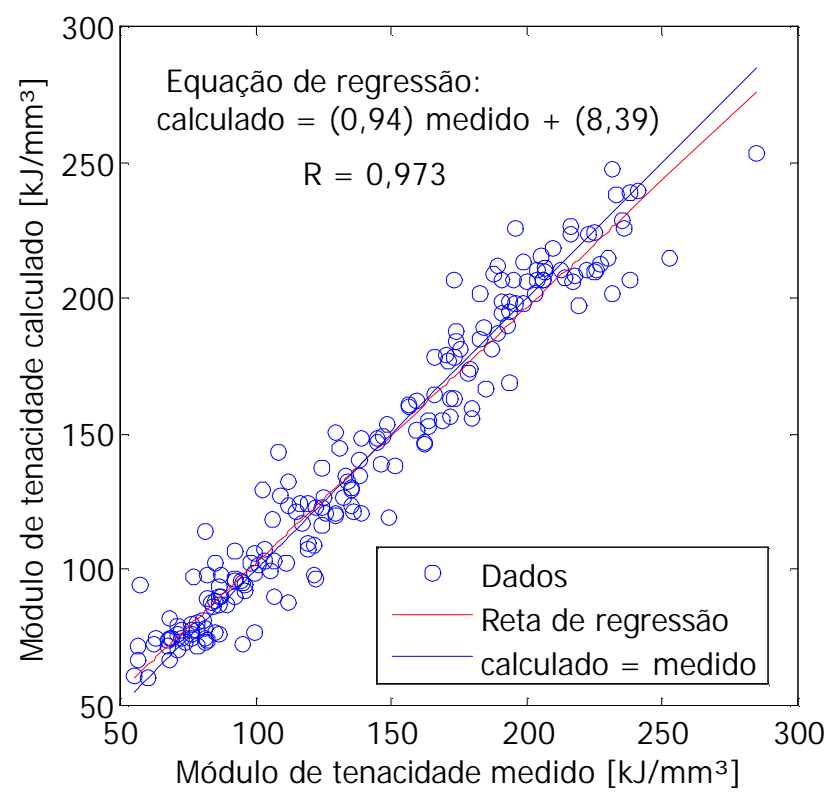

Figura 121: Correlação entre o $U_{t}$ medido e o $U_{t}$ calculado pela RNA para o conjunto de treinamento.

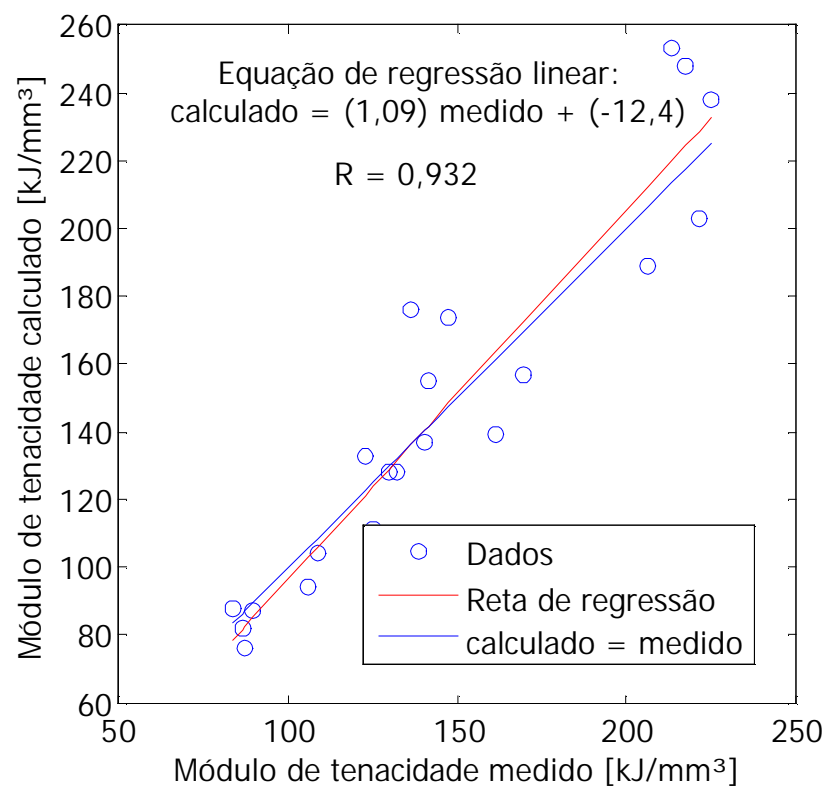

Figura 122: Correlação entre o $U_{t}$ medido e o $U_{t}$ calculado pela RNA para o conjunto de treinamento.

As Figuras 123, 124, 125, 126 e 127 trazem a comparação dos resultados medidos e calculados pela RNA para os aços AISI 4140, 4340, 5150, 6150 e E52100 respectivamente. 


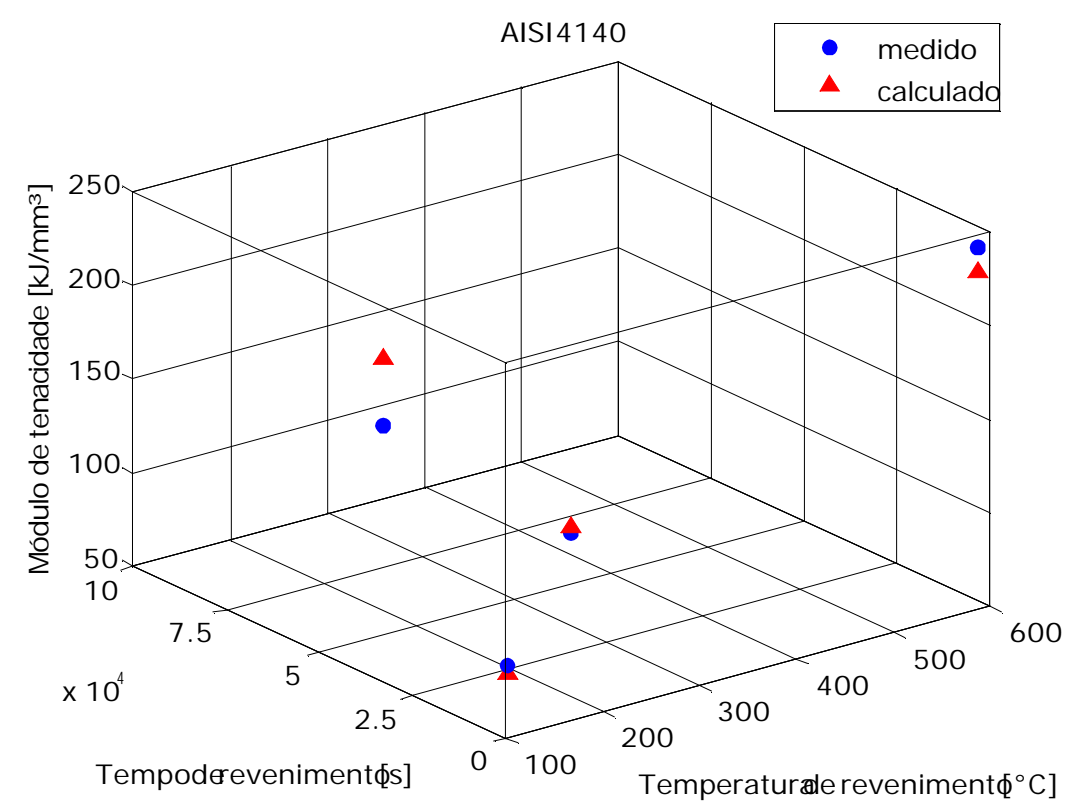

Figura 123: Comparação dos resultados calculados pela RNA com os valores medidos para o $\mathrm{U}_{\mathrm{t}}$ obtido pelo conjunto de teste do aço AISI 4140.

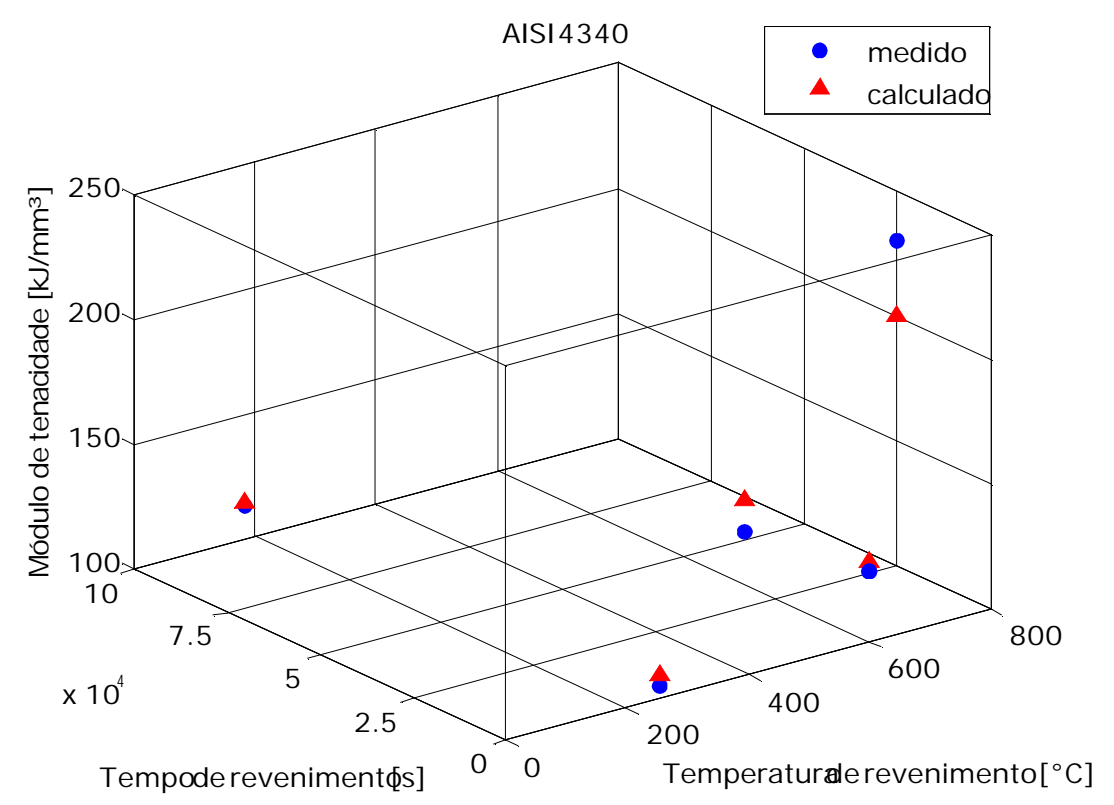

Figura 124: Comparação dos resultados calculados pela RNA com os valores medidos para o $U_{t}$ obtido pelo conjunto de teste do aço AISI 4340. 


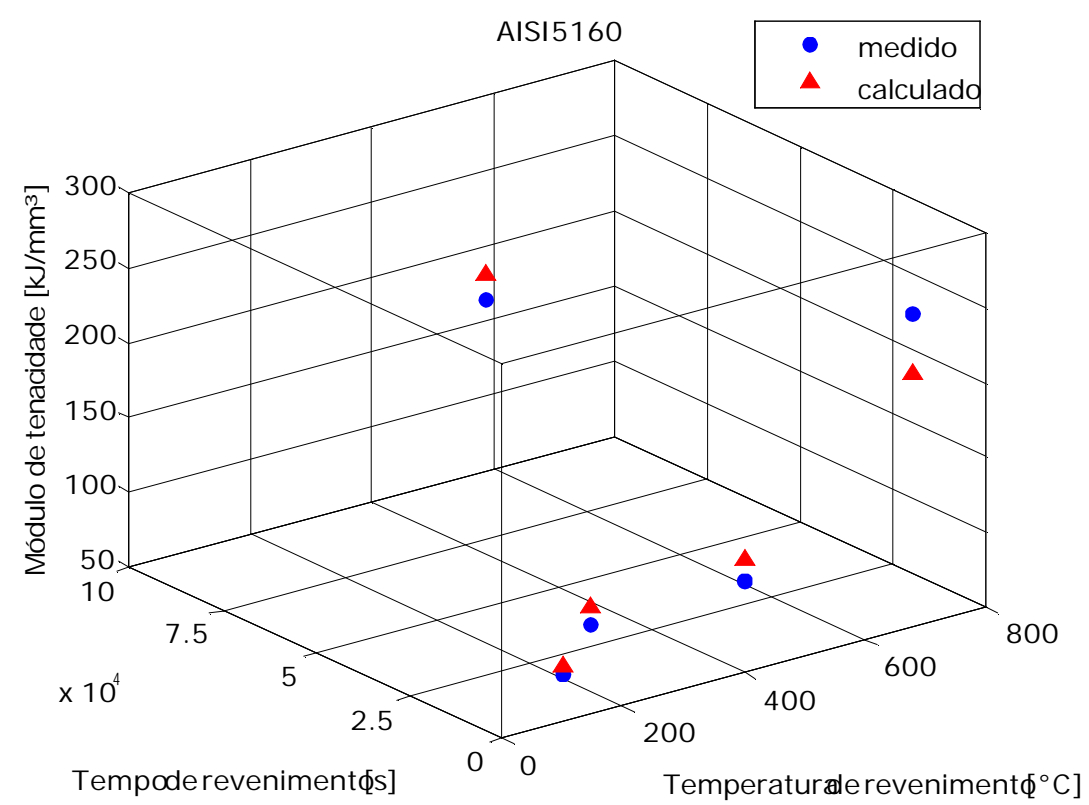

Figura 125: Comparação dos resultados calculados pela RNA com os valores medidos para o $U_{t}$ obtido pelo conjunto de teste do aço AISI 5160.

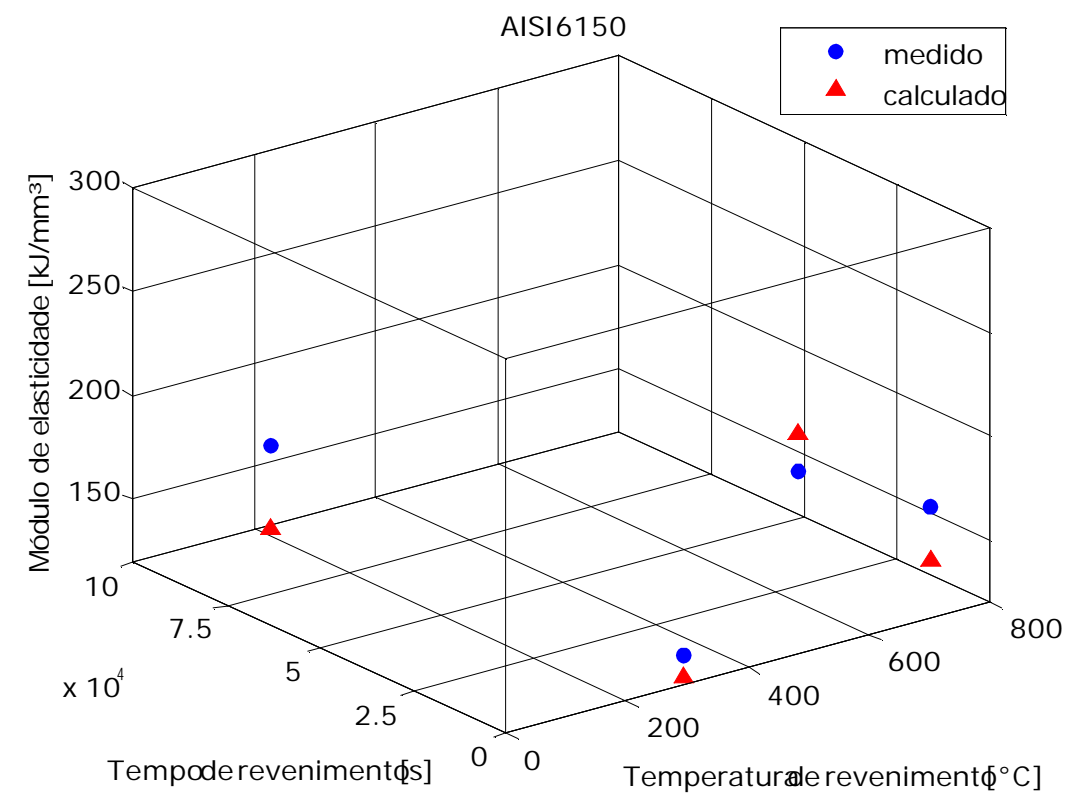

Figura 126: Comparação dos resultados calculados pela RNA com os valores medidos para o $U_{t}$ obtido pelo conjunto de teste do aço AISI 6150. 


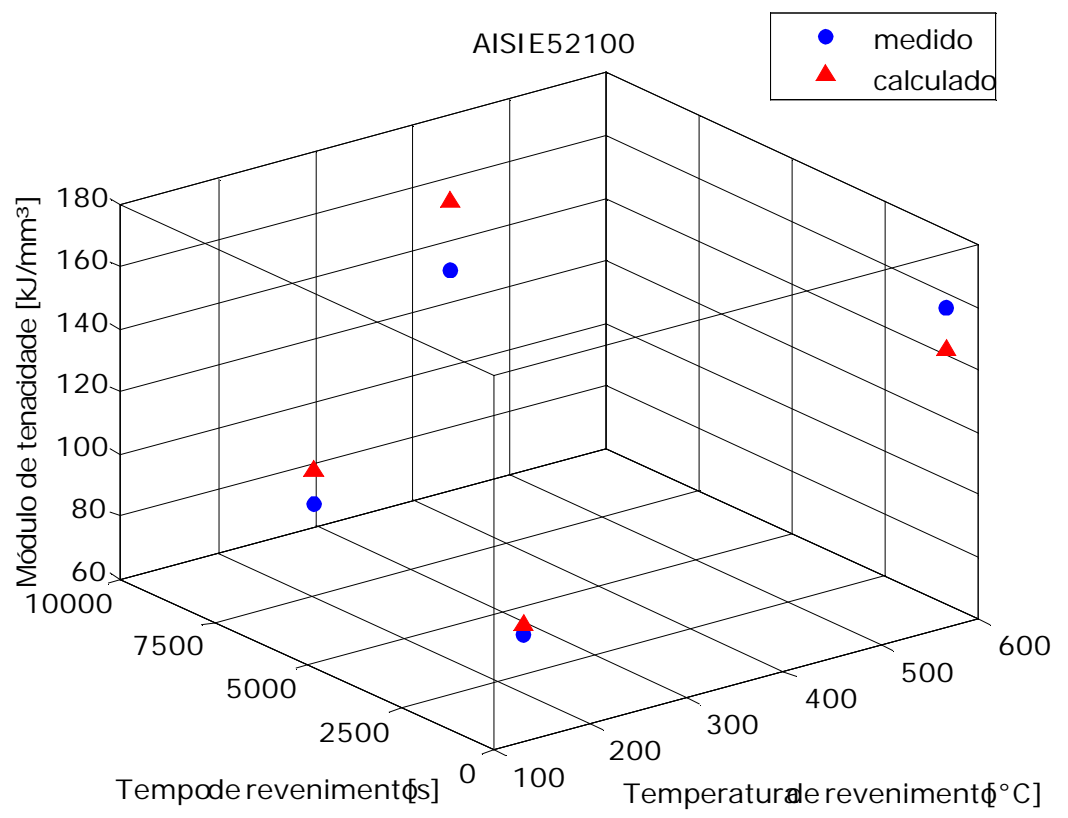

Figura 127: Comparação dos resultados calculados pela RNA com os valores medidos para o $\mathrm{U}_{\mathrm{t}}$ obtido pelo conjunto de teste do aço AISI E52100.

Em resumo, os valores utilizados para validação de cada propriedade podem ser observados na Tabela 28. O que se nota é um melhor ajuste para a dureza, para - LRT e para o LE. Este resultado certamente foi alcançado porque estas redes possuíam um conjunto de dados mais amplo. Os resultados obtidos para a tensão de ruptura e para os módulos de tenacidade e de escoamento exibiram um ajuste menos preciso, mas com um bom nível de acurácia. A base de dados utilizada para calcular estas propriedades era menor e pode explicar esta diferença. Em relação ao módulo de tenacidade, pode-se ressaltar ainda a complexidade do problema, pois seu valor diferentemente das outras propriedades não possui um comportamento óbvio, do tipo aumenta ou diminui com o acréscimo da temperatura.

Tabela 28: Resumo das técnicas utilizadas para validar o problema.

\begin{tabular}{cccc}
\hline Propriedade & $R_{\text {treinamento }}$ & $R_{\text {teste }}$ & Confiança \\
\hline Dureza & 0,993 & 0,983 & $99,5 \%$ \\
LRT & 0,993 & 0,989 & $99 \%$ \\
LE & 0,996 & 0,979 & $99 \%$ \\
$\sigma_{r}$ & 0,993 & 0,983 & $93 \%$ \\
$U_{r}$ & 0,992 & 0,983 & $92 \%$ \\
$U_{t}$ & 0,973 & 0,932 & $99 \%$ \\
\hline
\end{tabular}


0 método de modelagem estabelecido permite, em ambiente MATLAB, que 0 usuário introduza o tempo e a temperatura de revenimento, mais a composição química do aço $(\% \mathrm{C}, \% \mathrm{Mn}, \% \mathrm{P}, \% \mathrm{~S}, \% \mathrm{Si}, \% \mathrm{Ni}, \% \mathrm{Cr}$ e $\% \mathrm{Mo})$ e receba automaticamente os valores de dureza, limite de resistência à tração, limite de escoamento, tensão de ruptura, módulo de resiliência e módulo de tenacidade. 


\section{CONCLUSÕES}

Os resultados obtidos nas simulações indicam que as redes neurais de fato ajustam bem os dados. A rede construída para calcular a dureza obteve um ótimo nível de generalização, permitindo um bom ajuste dos dados. 0 parâmetro de Hollomon-Jaffe de fato não ajusta bem os aços ligados, especialmente quando revenidos por tempos curtos.

O modelo desenvolvido é especialmente importante para determinar os módulos de tenacidade e de resiliência e que são dados difíceis de serem encontrados na literatura técnica.

Dado o excelente desempenho do modelo utilizado sugere-se que possa ser utilizado para os aços de baixa liga na previsão das propriedades mecânicas de dureza, limite de resistência à tração, limite de elasticidade, tensão de ruptura, módulo de resiliência e módulo de tenacidade. 


\section{SUGESTÕES PARA TRABALHOS FUTUROS}

- Construir uma rede para os aços de média e alta liga em especial para os que apresentam o endurecimento secundário,

- Desenvolver um modelo que considere a dureza como temperada como variável de entrada,

- Considerar corpos de prova com espessuras variadas,

- Montar um pacote para unificar todas as redes em um só ambiente. 


\section{REFERÊNCIAS}

AMERICAN SOCIETY FOR METALS (1998). Metals Handbook: Heat treating, v.4. Materials Park: ASM International.

AMERICAN SOCIETY FOR METALS (2000). Metals Handbook: Mechanical testing e evaluation, v.8. Materials Park: ASM International.

AMERICAN SOCIETY FOR METALS (2003). Metals Handbook: Metallography and microstructures, v.9. Materials Park: ASM International.

AMERICAN SOCIETY FOR TESTING MATERIALS (2004). ASTM E8M: Standard test for method for determination of cooling curves characteristics of quench oils by cooling curve analysis. West Conshohocken.

AMERICAN SOCIETY FOR TESTING MATERIALS (2007). ASTM E140 - 07: Standard hardness conversion tables for metals relationship among brinell hardness, Vickers hardness, Rockwell hardness, superficial hardness, knoop hardness, and scleroscope hardness. West Conshohocken.

AMERICAN SOCIETY FOR TESTING MATERIALS (2007). ASTM D6200: Standard test for methods for tension testing of Metallic Materials [Metric]. West Conshohocken.

BAIN, E.C.; PAXTON, H.W. (1961). Alloying elements in steel. American Society for Metals, p.185, 197.

BETHLHEN STEEL CORPORATION (1972). Modern steels and their properties, handbook 2757. Bethlehem.

BROOKS, C. (1996). Principles of the heat treatment of plain carbon and low alloy steels. Materials Park, $\mathrm{OH}$ : ASM International.

CALLISTER, W. D. (2002). Ciência e engenharia dos materiais: uma introdução. Rio de Janeiro: Livros técnicos e científicos.

CANALE, L.C.F. et al. (2005). The development and use of the Lason-Miller equation and Hollomon-J affe parameters for stress-relieving operations: A review. In: $\mathbf{6 1 0}$ Congresso Anual da ABM, 24 a 27 de julho de 2005, Rio de Janeiro, Brasil.

CHENG, B.; TITTERINTON, D. M. (1994). Neural Networks: A review from a statistical perspective. In: Statistical Sciences, v. 9, n.1, p. 2-30. 
COHEN, M. (1962). The strengthening of steel. Transactions TMS-AI ME, v.224, p.638-675.

DAN FORESEE, F.; HAGAN, M. T. (1997). Gauss-newton approximation to bayesian learning. International Conference on Neural Networks. Houston: IEEE. v.3, p.1930-1935.

DE CASTRO, L. N. (1998). Análise e síntese de estratégias de aprendizado para redes neurais artificiais. 246f. Dissertação (Mestrado) DCA/FEEC/UNICAMP, Campinas, 1998.

FILETIN, T.; et al. (1999). Predicting the tempering curve of tool steels using neural networks. $2^{\text {nd }}$ International Conference on Industrial Tools, Maribor, Slovenia, ICIT, Proceedings...p.424-427.

GRANGE, R.A.; HIBRAL, C.R.; PORTER, L.F. (1977). Hardness of tempered martensite in carbon and low-alloy steels. Metallurgical Transactions A, v.8A, p.1775-1785.

GRANGE, R.A.; BAUGHMAN, R.W. (1956). Hardness of tempered martensite in carbon and low alloy steels. In: Transactions of American Society for Metals, v.XLVII, p.165-197.

HAGAN, M. T.; MENHAJ, M. B. (1994). Training feedforward networks with the Marquardt algorithm. I EEE Transactions on Neural Networks, v.5, n.6, p.989993.

HAYKIN, S. (1994). Neural Networks: A comprehensive foundation. New York: MacMillan Publishing Company.

HARVEY, P. D. (1982). Engineering properties of steel. Metals Park, Ohio: American Society for Metals.

HOLLOMON, J.F.; JAFFE, L.D. (1945). Time-temperature relations in tempering steel. Transactions of AI ME, v.162, p.223-249.

HONEYCOMBE; R.W.K.; BHADESHIA, H.K.D.H. (1995). Steels: microstructure and properties. Edward Arnold, London.

HUANG, R. (2003). ASE324: Aerospace Materials Laboratory - Lecture 10. Department of Aerospace Engineerning and Materials Mechanics, The University of Texas at Austin, Sept. 30, 2003.

KESSLER, B. S. (2005). Development of an integrated approach combining neural network material based modeling with finite element analysis of 
forming process. $245 f$. Dissertation (partial fulfillment of the requirements for $\mathrm{PhD}$ degree) - University of Missouri, Columbia, 2005.

KRAUSS, G. (1984). Tempering and structural change in ferrous martensitic structures. In: INTERNATIONAL CONFERENCE ON PHASE TRANSFORMATIONS IN FERROUS ALLOYS, 1983, Philadelphia. Proceedings... New York: AIME. p.101-123.

KRAUSS, G. (1990). Principles of heat treatment of steel. Materials Park: American Society for Metals, p.187-227.

INOUE, T. (1980). A new tempering parameter and its application to the integration of tempering effect of continuous heat cycle. Journal of the Iron and Steel Institute, v. 66, n.10, p.1532-1541.

LARSON, F. R.; MILLER, J. (1952). A time-temperature relationship for rupture and creep stresses. Transactions of the ASME, v.74, p.765-775.

MANSON, S. S.; HAFERD, A. (1953). A linear time-temperature relation for extrapolation of creep and stress-rupture data. NACA (National Advisory Committee for aeronautics), T.N. 2890, March.

MATHWORKS (2008). Getting started with MATLAB. Mathworks, v.7.7 - R2008b.

MONTGOMERY, D. (1997). Design and analysis of experiments. New York: John Wiley.

MURPHY, S.; WOOFHEAD, J. H. (1972). An investigation into the validity for certain tempering parameters. Metallurgical Transactions, v.3, p.727-735, March.

NAM, W. J.; et al. (2000). Effects of alloy additions and tempering temperature on the sag resistance of $\mathrm{Si}-\mathrm{Cr}$ spring steels. Materials Science and Engineering, v.A289, p.8-17.

NEHRENBERG, A.E. (1950). Master curves simplify stainless tempering. Steel, v.127, p.72-76.

SINGH, S.B. et al. (1998). Neural network analysis of steel plate processing. Ironmaking and Steelmaking, v.25, n.5, p.355-365.

SHEPPARD, C.P.; GENT, C. R. (1991). A neural network based sonar classification system. Proceedings of the Europe 1991 MILCOMP Conference: Military Computers - Systems and Software, p. 181-186.

TOTTEN, G.E; BATES, C.E.; CLINTON, N.A. (1993). Handbook of quenchants and quenching technology. Materials Park: ASM International. 
VATAVUK, J.; CANALE, L. C. F. (2008). Steel failures due to tempering and isothermal heat treatment. CANALE L. C. F. et al. Failure analysis of heat treated steel components. Materials Park, OH: ASM International. p.285-309.

WAN, N.; et al. (2005). Mathematical model for tempering time effect on quenched steel based on Hollomon parameter. J. Materials Science Technology, v.21, n.6, p. 803-806.

ZHANG, Z.; et al. (2004). Microstructure evolution of hot-work tool steels during tempering and definition of a kinetic law based on hardness measurements. Materials Science and Engineering A, v.380, p.222-230. 


\section{ANEXO A - Dureza}

Tabela 29: Dureza para o aço 1045

\begin{tabular}{cccccc}
\hline $\begin{array}{c}\text { Tempo } \\
{[\mathrm{s}]}\end{array}$ & $\begin{array}{c}\text { Temperatura } \\
{[\mathrm{O} C]}\end{array}$ & $\begin{array}{c}\text { Dureza } \\
{[\mathrm{HV}]}\end{array}$ & $\begin{array}{c}\text { Tempo } \\
{[\mathrm{s}]}\end{array}$ & $\begin{array}{c}\text { Temperatura } \\
{[\mathrm{O} C]}\end{array}$ & $\begin{array}{c}\text { Dureza } \\
{[\mathrm{HV}]}\end{array}$ \\
\hline & 204 & 631 & & 204 & 586 \\
& 260 & 594 & & 260 & 554 \\
& 315 & 533 & & 315 & 502 \\
600 & 371 & 487 & & 371 & 439 \\
& 427 & 427 & \multirow{2}{*}{14400} & 427 & 375 \\
& 482 & 371 & & 482 & 328 \\
& 538 & 329 & & 538 & 286 \\
& 539 & 295 & & 539 & 251 \\
& 649 & 262 & & 649 & 224 \\
& 704 & 229 & & 704 & 194 \\
\hline \multirow{6}{*}{3600} & 204 & 618 & & 204 & 575 \\
& 260 & 564 & & 260 & 533 \\
& 315 & 517 & & 315 & 478 \\
& 371 & 459 & & 371 & 409 \\
& 427 & 398 & 86400 & 427 & 353 \\
& 482 & 348 & & 482 & 299 \\
& 538 & 305 & & 538 & 262 \\
& 539 & 269 & & 539 & 229 \\
& 649 & 239 & & 649 & 200 \\
\hline
\end{tabular}

(GRANGE e BAUGHMAN, 1956).

Tabela 30: Composição química

\begin{tabular}{ccccccccc}
\hline Aço AISI & $\% \mathrm{C}$ & $\% \mathrm{Mn}$ & $\% \mathrm{P}$ & $\% \mathrm{~S}$ & $\% \mathrm{Si}$ & $\% \mathrm{Ni}$ & $\% \mathrm{Cr}$ & $\% \mathrm{Mo}$ \\
\hline 1045 & 0,45 & 0,73 & 0,017 & 0,030 & 0,17 & 0,01 & 0,02 & 0,01 \\
2340 & 0,37 & 0,68 & 0,014 & 0,021 & 0,21 & 3,41 & 0,05 & - \\
4140 & 0,37 & 0,77 & 0,019 & 0,026 & 0,15 & 0,04 & 0,98 & 0,21 \\
4340 & 0,42 & 0,78 & 0,018 & 0,027 & 0,24 & 1,79 & 0,80 & 0,33 \\
4640 & 0,36 & 0,63 & 0,018 & 0,021 & 0,19 & 1,84 & 0,06 & 0,23 \\
5140 & 0,42 & 0,68 & 0,026 & 0,032 & 0,16 & 0,07 & 0,93 & - \\
6145 & 0,43 & 0,74 & 0,019 & 0,024 & 0,23 & 0,06 & 0,92 & - \\
\hline
\end{tabular}


Tabela 31: Dureza dos aços ligados

\begin{tabular}{|c|c|c|c|c|c|c|c|}
\hline \multirow{2}{*}{ Tempo[s] } & \multirow[b]{2}{*}{ Temperatura $\left[{ }^{\circ} \mathrm{C}\right]$} & \multicolumn{6}{|c|}{ Dureza [HV] } \\
\hline & & 2340 & 4140 & 4340 & 4640 & 5140 & 6140 \\
\hline \multirow{4}{*}{40} & 427 & 432 & 482 & 500 & 450 & 489 & 502 \\
\hline & 538 & 361 & 421 & 435 & 383 & 416 & 409 \\
\hline & 593 & 331 & 385 & 400 & 358 & 388 & 392 \\
\hline & 649 & 307 & 343 & 377 & 330 & 346 & 381 \\
\hline \multirow{4}{*}{120} & 427 & 408 & 472 & 481 & 427 & 479 & 489 \\
\hline & 538 & 340 & 406 & 434 & 381 & 395 & 399 \\
\hline & 593 & 320 & 371 & 414 & 350 & 377 & 380 \\
\hline & 649 & 283 & 335 & 365 & 325 & 341 & 373 \\
\hline \multirow{4}{*}{900} & 427 & 384 & 464 & 472 & 418 & 466 & 481 \\
\hline & 538 & 314 & 394 & 431 & 376 & 384 & 393 \\
\hline & 593 & 284 & 355 & 391 & 336 & 356 & 373 \\
\hline & 649 & 262 & 332 & 348 & 307 & 317 & 361 \\
\hline \multirow{9}{*}{3600} & 204 & 453 & 451 & 451 & 416 & 453 & 461 \\
\hline & 260 & 510 & 384 & 405 & 362 & 373 & 382 \\
\hline & 315 & 473 & 339 & 388 & 333 & 336 & 354 \\
\hline & 371 & 421 & 314 & 338 & 293 & 309 & 350 \\
\hline & 427 & 366 & 585 & 593 & 546 & 596 & 593 \\
\hline & 482 & 331 & 531 & 545 & 513 & 541 & 544 \\
\hline & 538 & 303 & 496 & 506 & 476 & 509 & 517 \\
\hline & 593 & 271 & 486 & 496 & 439 & 491 & 493 \\
\hline & 649 & 240 & 448 & 456 & 398 & 437 & 450 \\
\hline \multirow{5}{*}{7200} & 204 & 546 & 403 & 423 & 365 & 386 & 403 \\
\hline & 315 & 461 & 373 & 389 & 331 & 344 & 373 \\
\hline & 427 & 359 & 346 & 365 & 311 & 313 & 354 \\
\hline & 538 & 284 & 311 & 322 & 266 & 285 & 304 \\
\hline & 649 & 227 & 581 & 586 & 542 & 584 & 583 \\
\hline \multirow{5}{*}{14400} & 204 & 540 & 490 & 510 & 466 & 509 & 515 \\
\hline & 315 & 454 & 436 & 448 & 388 & 424 & 436 \\
\hline & 427 & 349 & 355 & 383 & 326 & 327 & 360 \\
\hline & 538 & 274 & 286 & 269 & 246 & 296 & 280 \\
\hline & 649 & 22 & 568 & 576 & 535 & 575 & 570 \\
\hline
\end{tabular}

(GRANGE e BAUGHMAN, 1956). 


\section{ANEXO B - Limite de resistência à tração e Limite de escoamento}

Tabela 32: Propriedades mecânicas

\begin{tabular}{|c|c|c|c|c|c|c|c|c|c|}
\hline \multirow[b]{2}{*}{$\begin{array}{c}\text { Temperatura } \\
{\left[{ }^{\circ} \mathrm{C}\right]}\end{array}$} & \multirow[b]{2}{*}{$\begin{array}{c}\text { Tempo } \\
\text { [s] }\end{array}$} & \multicolumn{2}{|c|}{$\mathrm{SCr} 440$} & \multicolumn{2}{|c|}{ SCM440 } & \multicolumn{2}{|c|}{ S40C } & \multicolumn{2}{|c|}{ SMn443 } \\
\hline & & $\begin{array}{c}\text { LRT } \\
\text { [MPa] }\end{array}$ & $\begin{array}{c}\mathrm{LE} \\
{[\mathrm{MPa}]}\end{array}$ & $\begin{array}{c}\text { LRT } \\
\text { [MPa] }\end{array}$ & $\begin{array}{c}\mathrm{LE} \\
{[\mathrm{MPa}]}\end{array}$ & $\begin{array}{l}\text { LRT } \\
\text { [MPa] }\end{array}$ & $\begin{array}{c}\mathrm{LE} \\
{[\mathrm{MPa}]}\end{array}$ & $\begin{array}{l}\text { LRT } \\
{[\mathrm{MPa}]}\end{array}$ & $\begin{array}{c}\mathrm{LE} \\
{[\mathrm{MPa}]}\end{array}$ \\
\hline \multirow{6}{*}{450} & 360 & 1604 & 1443 & 1643 & 1498 & 1176 & 1001 & 1496 & 1496 \\
\hline & 360 & 1450 & 1329 & 1542 & 1419 & 1175 & 1084 & 1355 & 1355 \\
\hline & 3600 & 1316 & 1201 & 1427 & 1309 & 1002 & 856 & 1251 & 1251 \\
\hline & 28800 & 1263 & 1172 & 1372 & 1256 & 969 & 812 & 1236 & 1237 \\
\hline & 360000 & 1126 & 1025 & 1298 & 1201 & 924 & 819 & 1106 & 1106 \\
\hline & 3600000 & 1019 & 905 & 1237 & 1106 & 823 & 702 & 1021 & 1021 \\
\hline \multirow{6}{*}{500} & 360 & 1427 & 1333 & 1492 & 1391 & 1029 & 878 & 1316 & 1316 \\
\hline & 360 & 1301 & 1163 & 1426 & 1340 & 1060 & 930 & 1247 & 1248 \\
\hline & 3600 & 1183 & 1098 & 1315 & 1212 & 932 & 771 & 1126 & 1126 \\
\hline & 28800 & 1060 & 961 & 1247 & 1152 & 902 & 774 & 1100 & 1101 \\
\hline & 360000 & 974 & 857 & 1179 & 1078 & 846 & 746 & 982 & 983 \\
\hline & 3600000 & 902 & 781 & 1071 & 947 & 699 & 548 & 894 & 895 \\
\hline \multirow{6}{*}{550} & 360 & 1182 & 1088 & 1303 & 1217 & 1016 & 871 & 1197 & 1198 \\
\hline & 360 & 1145 & 1047 & 1277 & 1193 & 986 & 882 & 1129 & 1130 \\
\hline & 3600 & 1008 & 898 & 1165 & 1066 & 850 & 690 & 1017 & 1017 \\
\hline & 28800 & 951 & 837 & 1084 & 983 & 803 & 674 & 966 & 966 \\
\hline & 360000 & 859 & 732 & 1003 & 947 & 710 & 602 & 844 & 845 \\
\hline & 3600000 & 750 & 627 & 915 & 810 & 564 & 442 & 737 & 738 \\
\hline \multirow{5}{*}{600} & 360 & 1084 & 976 & 1215 & 1124 & 926 & 763 & 1093 & 1094 \\
\hline & 360 & 1012 & 892 & 1127 & 1020 & 880 & 754 & 996 & 997 \\
\hline & 3600 & 931 & 815 & 1035 & 933 & 778 & 677 & 917 & 917 \\
\hline & 8800 & 855 & 730 & 960 & 849 & 708 & 553 & 880 & 880 \\
\hline & 0000 & 746 & 617 & 864 & 749 & 644 & 533 & 730 & 730 \\
\hline \multirow{6}{*}{650} & 360 & 998 & 867 & 1108 & 1002 & 860 & 740 & 988 & 989 \\
\hline & 360 & 943 & 814 & 1054 & 841 & 775 & 656 & 920 & 920 \\
\hline & 3600 & 861 & 736 & 932 & 812 & 695 & 538 & 831 & 831 \\
\hline & 28800 & 764 & 635 & 836 & 720 & 646 & 541 & 751 & 752 \\
\hline & 360000 & 640 & 516 & 691 & 596 & 556 & 444 & 637 & 638 \\
\hline & 3600 & 763 & 628 & 807 & 694 & 633 & 524 & 720 & 720 \\
\hline
\end{tabular}

(INOUE, 1980). 
(a)

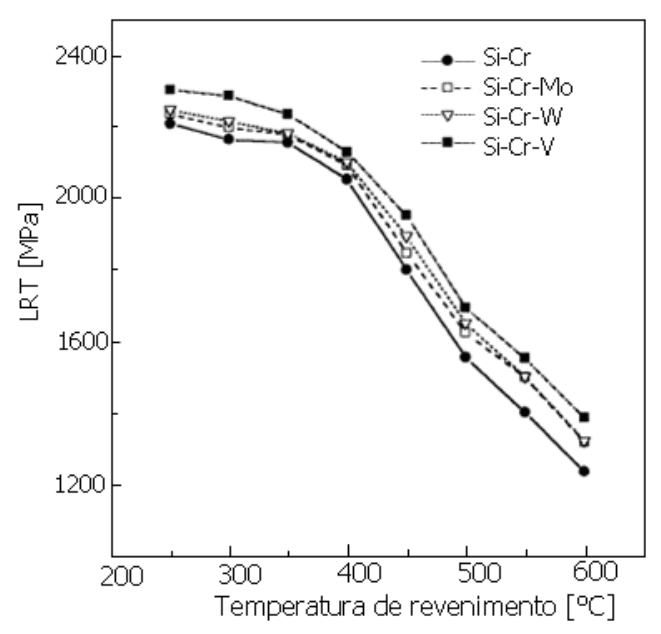

(b)

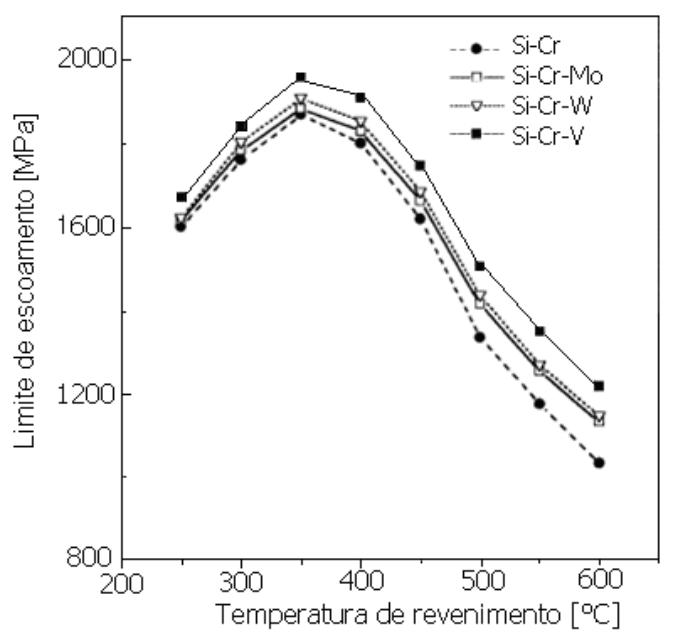

Figura 128: LRT e LE para os aços Si-Cr, S-Cr-Mo, Si-Cr-W e Si-Cr-V (NAM et al., 2000).

Tabela 33: Composição química

\begin{tabular}{lcccccccc}
\hline Aço & $\% \mathrm{C}$ & $\% \mathrm{Mn}$ & $\% \mathrm{P}$ & $\% \mathrm{~S}$ & $\% \mathrm{Si}$ & $\% \mathrm{Ni}$ & $\% \mathrm{Cr}$ & $\% \mathrm{Mo}$ \\
\hline SCr440 & 0,4 & 0,78 & 0,024 & 0,012 & 0,29 & 0 & 1,05 & 0,02 \\
SCM440 & 0,4 & 0,75 & 0,023 & 0,015 & 0,26 & 0 & 1,04 & 0,2 \\
S40C & 0,43 & 0,78 & 0,023 & 0,017 & 0,23 & 0 & 0,04 & 0,02 \\
SMn443 & 0,41 & 1,49 & 0,019 & 0,019 & 0,27 & 0 & 0,09 & 0,02 \\
Si-Cr & 0,59 & 0,50 & 0 & 0 & 1,51 & 0 & 0,50 & 0 \\
Si-Cr-Mo & 0,60 & 0,50 & 0 & 0 & 1,49 & 0 & 0,50 & 0,10 \\
Si-Cr-W & 0,61 & 0,49 & 0 & 0 & 1,54 & 0 & 0,49 & 0 \\
Si-Cr-V & 0,60 & 0,49 & 0 & 0 & 1,47 & 0 & 0,49 & 0 \\
\hline \multicolumn{7}{l}{ INOUE, 1980; NAM et al., 2000). }
\end{tabular}

